Supporting Information For

\title{
Rapid De Novo Preparation of 2,6-Dideoxy Sugar Libraries through Gold- Catalyzed Homopropargyl Orthoester Cyclization
}

\author{
Subbarao Yalamanchili, William Miller, Xizhao Chen, Clay S. Bennett* \\ Department of Chemistry, Tufts University, 62 Talbot Ave., Medford, MA 02155, United States
}

Table of Contents:

$\begin{array}{ll}\text { S1. General Experimental } & \text { S2 }\end{array}$

S2. Experimental Section

S2.1 Synthesis of 1,2-anti Substituted Orthoester Substrates (-)-1, (+)-1, (+)-2 $\quad$ S3

S2.2 Synthesis of 1,2-syn Substituted Orthoester Substrates (-)-3, (+)-3 S12

$\begin{array}{lr}\text { S2.3 General Procedure for Gold-Catalyzed Cyclizations } & \text { S17 }\end{array}$

$\begin{array}{lr}\text { S2.4 Synthesis of Enones (+)-4, (-)-4, (-)-5, (+)-6, (-)-6 } & \text { S17 }\end{array}$

$\begin{array}{lr}\text { S3. Derivatization of Enones into Deoxy Sugars } & \text { S20 }\end{array}$

$\begin{array}{lr}\text { S3.1 Synthesis of L-digitoxose (-)-7 } & \text { S20 }\end{array}$

$\begin{array}{lr}\text { S3.2 Synthesis of L-olivose (-)-8 } & \text { S22 }\end{array}$

$\begin{array}{lr}\text { S3.3 Synthesis of D-boivinose (+)-9 } & \text { S24 }\end{array}$

$\begin{array}{lr}\text { S3.4 Synthesis of D-oliose (+)-10 } & \text { S26 }\end{array}$

$\begin{array}{lr}\text { S3.5 Synthesis of L-ristosamine (-)-11 } & \text { S28 }\end{array}$

$\begin{array}{lr}\text { S3.6 Synthesis of L-saccharosamine (-)-12 S30 } & \text { S2 }\end{array}$

$\begin{array}{lr}\text { References } & \text { S32 }\end{array}$

$\begin{array}{lr}\text { NMR Spectra }{ }^{1} \mathrm{H},{ }^{13} \mathrm{C} & \text { S33 }\end{array}$ 


\section{S1. General Experimental}

All reactions were performed under inert argon atmosphere, unless otherwise noted. Solvents for reactions were dried through a commercial solvent purification system immediately prior to use. All other chemicals were purchased at the highest possible quality and used as received. Flash column chromatography was performed on 230-400 mesh silica gel. For reactions that required heating, an oil bath was used, and the temperature was adjusted using a digital thermometer that was connected to the stir plate. Silica gel was neutralized as needed by stirring for 30 minutes in a solution of 4:1:0.1 hexanes:ethyl acetate:triethyl amine. Analytical and preparative thin layer chromatography was carried out on silica gel 60 F-254 plates. Products were visualized using UV or by staining with either $5 \%$ aqueous sulfuric acid or ceric ammonium molybdate. NMR spectra were recorded on a NMR spectrometer at either $500 \mathrm{MHz}$ or $300 \mathrm{MHz}$ for ${ }^{1} \mathrm{H}$ NMR and $125 \mathrm{MHz}$ for ${ }^{13} \mathrm{C}$ NMR. Chemical shifts are reported in ppm relative to TMS (for ${ }^{1} \mathrm{H} \mathrm{NMR}$ in $\mathrm{CDCl}_{3}$ ) or $\mathrm{CDCl}_{3}$ (for ${ }^{13} \mathrm{C} \mathrm{NMR}$ in $\mathrm{CDCl}_{3}$ ). For ${ }^{1} \mathrm{H} \mathrm{NMR}$ spectra, data are reported as follows: $\delta$ shift, multiplicity $(\mathrm{s}=$ singlet, $\mathrm{m}=$ multiplet, $\mathrm{t}=$ triplet, $\mathrm{d}=$ doublet, $\mathrm{q}=$ quartet, brs $=$ broad singlet, $\mathrm{dd}$ $=$ doublet of doublets, $\mathrm{dq}=$ doublet of quartets, $\mathrm{ddd}=$ doublet of doublet of doublets, $\mathrm{qd}=$ quartet of doublets), coupling constants are reported in Hz. Low-resolution mass spectra (LRMS) were recorded using a ESI-MS with an additional APCI source. High-resolution mass spectra (HRMS) were obtained on ElectroSpray Ionization (ESI) on a Waters Qtof Premier instrument in the positive mode or Fourier Transform Ion Cyclotron Resonance Mass Spectrometer (FT- ICR-MS) with direct analysis in real time (DART) ionization source. Optical rotations were measured at 589 $\mathrm{nm}$ in a $5 \mathrm{~cm}$ cell at $24{ }^{\circ} \mathrm{C}$. 


\section{S2. Experimental Procedure}

S2.1 Preparation of 1,2-anti-substituted Orthoester Substrates (-)-1, (+)-1, and (+)-2.

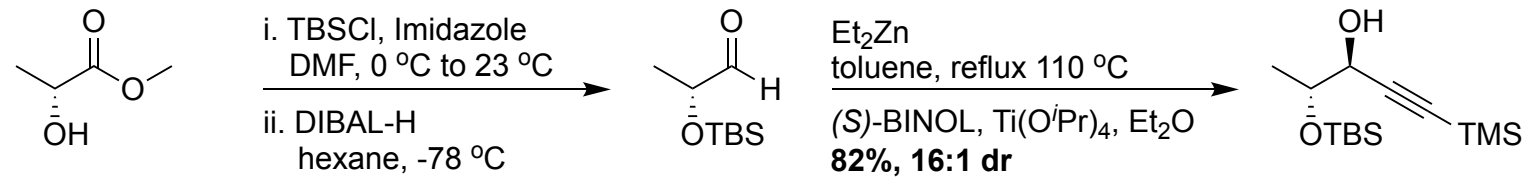

Methyl (R)-(+)-Lactate $13 \quad 78 \%$, over two steps

$(+)-14$

$(-)-15$
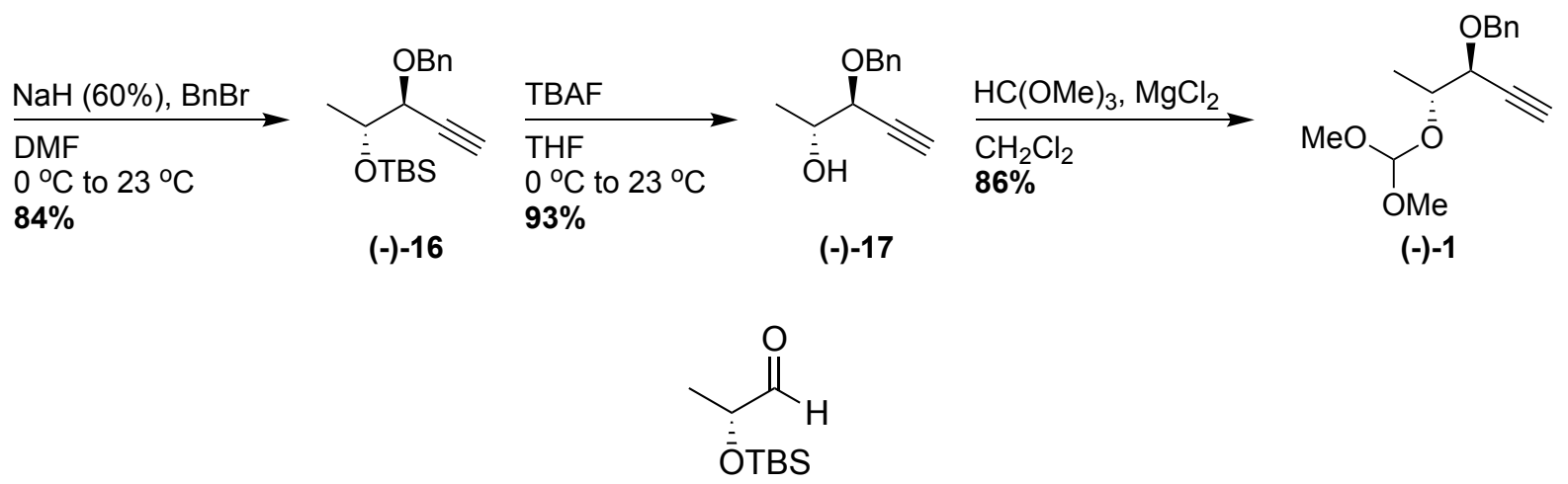

$(+)-14$

\section{(R)-2-((tert-butyldimethylsilyl)oxy)propanal (+)-14}

i. The first step in the synthesis of the title compound was performed using a procedure adapted from Webb et al. ${ }^{1}$ Methyl $(R)-(+)$-lactate $(10.0 \mathrm{~mL}, 106 \mathrm{mmol})$ and imidazole $(10.8 \mathrm{~g}, 159 \mathrm{mmol})$ were dissolved in DMF $(60 \mathrm{~mL})$ and cooled to $0{ }^{\circ} \mathrm{C}$. Tert-butyldimethylsilyl chloride $(23.9 \mathrm{~g}, 159$ mmol) was added to the stirred solution at $0{ }^{\circ} \mathrm{C}$, giving a white, cloudy mixture. The reaction was stirred at $0{ }^{\circ} \mathrm{C}$ for 15 minutes and then removed from the ice bath and stirred at $23{ }^{\circ} \mathrm{C}$. After 1 hour, the reaction was quenched with methanol $(20 \mathrm{~mL})$, diluted with $\mathrm{H}_{2} \mathrm{O}(400 \mathrm{~mL})$, and extracted with $\mathrm{CH}_{2} \mathrm{Cl}_{2}$ (3x). The pooled organic layers were washed with $1 \mathrm{M} \mathrm{LiCl}(3 \mathrm{x})$, brine $(1 \mathrm{x})$, dried over $\mathrm{Na}_{2} \mathrm{SO}_{4}$, filtered, and concentrated in vacuo at $25^{\circ} \mathrm{C}$. The resulting colorless oil was carried on crude.

ii. The second step in the synthesis was performed using a procedure adapted from Ito. ${ }^{2}$ In a flamed-dried round bottom flask, a portion of the crude oil $(5.0 \mathrm{~g})$ was dissolved in anhydrous hexanes $(45 \mathrm{~mL})$ and cooled to $-78{ }^{\circ} \mathrm{C}$. In another flame-dried round bottom flask, a solution of DIBAL-H (1.0 M in hexanes, $29.8 \mathrm{~mL}, 29.8 \mathrm{mmol})$ was added and cooled to $-78{ }^{\circ} \mathrm{C}$. The DIBAL$\mathrm{H}$ solution was transferred to the flask containing the aldehyde via cannula dropwise over 10 minutes. The reaction was stirred at $-78{ }^{\circ} \mathrm{C}$ for 2.5 hours, during which time it became progressively more opaque as the reaction progressed. Upon consumption of the starting material, the reaction was quenched with $\mathrm{MeOH}(5 \mathrm{~mL})$ at $-78{ }^{\circ} \mathrm{C}$ and then promptly removed from the -78 ${ }^{\circ} \mathrm{C}$ bath. After stirring the solution for 15 minutes at $23{ }^{\circ} \mathrm{C}$, sat. aq. Rochelle's salt $(45 \mathrm{~mL})$ was added and the mixture was stirred vigorously for two hours. The resulting biphasic mixture was separated, and the aqueous layer was extracted with hexanes $(5 \mathrm{x})$. The pooled organic layers were 
washed with $\mathrm{H}_{2} \mathrm{O}(1 \mathrm{x})$, brine (1x), dried over $\mathrm{Na}_{2} \mathrm{SO}_{4}$, filtered, and concentrated in vacuo at $20{ }^{\circ} \mathrm{C}$. Purification by flash chromatography on silica gel (30 to $40 \% \mathrm{CH}_{2} \mathrm{Cl}_{2}$ in hexanes) afforded aldehyde (+)-14 (3.36 g, 78\% over two steps) as a colorless oil. The aldehyde was noted to readily evaporate on high vacuum and was dried in a vacuum desiccator over 8 mesh Drierite. The spectroscopic data was in good agreement with previously reported values. ${ }^{2}$

${ }^{1} \mathrm{H} \mathrm{NMR}\left(500 \mathrm{MHz}, \mathrm{CDCl}_{3}\right) \delta 9.61(\mathrm{~d}, J=1.2 \mathrm{~Hz}, 1 \mathrm{H}), 4.09(\mathrm{qd}, J=6.8,1.2 \mathrm{~Hz}, 1 \mathrm{H}), 1.28(\mathrm{~d}, J$ $=6.9 \mathrm{~Hz}, 3 \mathrm{H}), 0.92(\mathrm{~s}, 9 \mathrm{H}), 0.11(\mathrm{~s}, 3 \mathrm{H}), 0.09(\mathrm{~s}, 3 \mathrm{H})$.

${ }^{13} \mathrm{C}$ NMR (125 MHz, $\left.\mathrm{CDCl}_{3}\right) \delta$ 204.1, 73.8, 25.7, 18.5, 18.2, -4.7, -4.8.

LRMS (ESI) m/z: [M+Na] $]^{+}$Calcd. for $\mathrm{C}_{9} \mathrm{H}_{20} \mathrm{O}_{2} \mathrm{SiNa}$ 211.11; Found 211.51 .

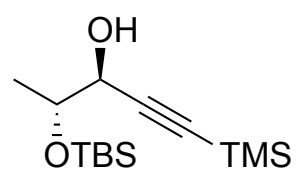

$(-)-15$

(2R,3S)-2-((tert-butyldimethylsilyl)oxy)-5-(trimethylsilyl)pent-4-yn-3-ol (-)-15

The synthesis of the title compound was performed using a procedure adapted from Marshall ${ }^{3}$. In a flame-dried two-neck round bottom flask, a solution of trimethylsilyl acetylene $(4.41 \mathrm{~mL}, 31.9$ $\mathrm{mmol})$ in anhydrous toluene $(31.1 \mathrm{~mL})$ was treated dropwise with diethylzinc $(1.5 \mathrm{M}$ in toluene, $21.2 \mathrm{~mL}, 31.9 \mathrm{mmol})$. The resulting solution was refluxed for 2.5 hours, resulting in the formation of a thick, grey precipitate. The mixture was cooled to $23{ }^{\circ} \mathrm{C}$ and diluted with anhydrous diethyl ether $(92 \mathrm{~mL})$. (S)-BINOL $(0.912 \mathrm{~g}, 3.19 \mathrm{mmol})$ and $\mathrm{Ti}\left(\mathrm{O}^{i} \mathrm{Pr}\right)_{4}(2.36 \mathrm{~mL}, 7.96 \mathrm{mmol})$ were added to the reaction flask, resulting in an orange, heterogeneous solution. After vigorously stirring for 1.5 hours at $23{ }^{\circ} \mathrm{C}$, the reaction was treated with a solution of compound $(+)-\mathbf{1 4}(1.50 \mathrm{~g}, 7.96 \mathrm{mmol})$ in anhydrous diethyl ether $(21 \mathrm{~mL})$. After stirring overnight at $23{ }^{\circ} \mathrm{C}$, the reaction was cooled to 0 ${ }^{\circ} \mathrm{C}$ and then quenched with $1 \mathrm{M}$ aq. tartaric acid $(150 \mathrm{~mL})$. The resulting mixture was stirred at 23 ${ }^{\circ} \mathrm{C}$ for $30 \mathrm{~min}$ and then diluted with $\mathrm{H}_{2} \mathrm{O}(200 \mathrm{~mL})$. The layers were separated, and the aqueous layer was extracted with $\mathrm{Et}_{2} \mathrm{O}(4 \mathrm{x})$. The pooled organic layers were washed with $\mathrm{H}_{2} \mathrm{O}(1 \mathrm{x})$, sat. aq. sodium bicarbonate (1x), brine (1x), dried over $\mathrm{Na}_{2} \mathrm{SO}_{4}$, filtered, and concentrated in vacuo at 25 ${ }^{\circ} \mathrm{C}$. Purification by flash column chromatography on silica gel (60\% dichloromethane in hexanes) afforded compound (-)-15 $(1.87 \mathrm{~g}, 82 \%, 16: 1 \mathrm{dr})$ as a white solid. The spectroscopic data is in good agreement with previously reported values. ${ }^{3}$

${ }^{1} \mathrm{H}$ NMR $\left(500 \mathrm{MHz}, \mathrm{CDCl}_{3}\right) \delta 4.25-4.21(\mathrm{~m}, 1 \mathrm{H}), 3.91(\mathrm{qd}, J=6.2,3.9 \mathrm{~Hz}, 1 \mathrm{H}), 2.32(\mathrm{~d}, J=5.5$ $\mathrm{Hz}, 1 \mathrm{H}), 1.23$ (d, $J=6.2 \mathrm{~Hz}, 3 \mathrm{H}), 0.90$ (s, 9H), 0.17 (s, 9H), 0.10 (s, 3H), 0.09 (s, 3H).

${ }^{13} \mathrm{C}$ NMR $\left(125 \mathrm{MHz}, \mathrm{CDCl}_{3}\right) \delta$ 103.7, 90.8, 70.9, 67.4, 25.8, 18.9, 18.0, -0.19, -4.4.

LRMS (ESI) m/z: [M+Na] $]^{+}$Calcd. for $\mathrm{C}_{14} \mathrm{H}_{30} \mathrm{O}_{2} \mathrm{Si}_{2} \mathrm{Na}$ 309.55; Found 309.96. 


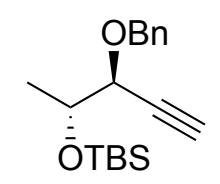

$(-)-16$

(2R, 3S)-2-(tert-buytldimethylsilyloxy)-3-(benzyloxy)-pent-4-yne (-)-16

A suspension of sodium hydride (60\% in mineral oil, $0.736 \mathrm{~g}, 18.4 \mathrm{mmol})$ in DMF $(24 \mathrm{~mL})$ was cooled to $0{ }^{\circ} \mathrm{C}$ and treated with a solution of (-)-15 (1.20 g, $\left.4.19 \mathrm{mmol}\right)$ in DMF $(27 \mathrm{~mL})$. After the mixture was stirred at $0{ }^{\circ} \mathrm{C}$ for $10 \mathrm{~min}$, benzyl bromide $(2.19 \mathrm{~mL}, 18.4 \mathrm{mmol})$ was added dropwise and the resulting mixture was warmed to $23{ }^{\circ} \mathrm{C}$ overnight. The reaction was then quenched with sat. aq. $\mathrm{NH}_{4} \mathrm{Cl}(30 \mathrm{~mL})$ at $23{ }^{\circ} \mathrm{C}$ and the resulting mixture was diluted with $\mathrm{H}_{2} \mathrm{O}$ $(400 \mathrm{~mL})$ and extracted with $\mathrm{Et}_{2} \mathrm{O}(4 \mathrm{x})$. The pooled organic layers were washed with $\mathrm{H}_{2} \mathrm{O}(2 \mathrm{x}), 1$ $\mathrm{M} \mathrm{LiCl}(2 \mathrm{x})$, brine $(1 \mathrm{x})$, dried over $\mathrm{Na}_{2} \mathrm{SO}_{4}$, filtered, and concentrated in vacuo at $25{ }^{\circ} \mathrm{C}$. Purification by flash column chromatography on silica gel (30\% dichloromethane in hexanes) afforded (-)-16 (1.08 g, 84\%) as a clear oil.

${ }^{1} \mathrm{H}$ NMR $\left(500 \mathrm{MHz}, \mathrm{CDCl}_{3}\right) \delta$ 7.38-7.27 (m, 5H), $4.82(\mathrm{~d}, J=12.0 \mathrm{~Hz}, 1 \mathrm{H}), 4.56(\mathrm{~d}, J=12.0 \mathrm{~Hz}$, $1 \mathrm{H}), 3.97-3.91(\mathrm{~m}, 1 \mathrm{H}), 3.89$ (dd, $J=5.4,1.9 \mathrm{~Hz}, 1 \mathrm{H}), 2.44(\mathrm{dd}, J=6.2,2.0 \mathrm{~Hz}, 1 \mathrm{H}), 1.25$ (d, $J=$ $6.1 \mathrm{~Hz}, 3 \mathrm{H}), 0.89(\mathrm{~s}, 9 \mathrm{H}), 0.07(\mathrm{~s}, 3 \mathrm{H}) 0.06(\mathrm{~s}, 3 \mathrm{H})$.

${ }^{13} \mathrm{C} \mathrm{NMR}\left(125 \mathrm{MHz}, \mathrm{CDCl}_{3}\right) \delta 137.8,128.3,128.0,127.6,81.5,74.5,73.8,70.9,70.7,25.8,19.8$, $18.1,-4.58,-4.63$.

LRMS (ESI) m/z: [M+Na $]^{+}$Calcd. for $\mathrm{C}_{18} \mathrm{H}_{28} \mathrm{O}_{2} \mathrm{SiNa}$ 327.18; Found 327.69.

HRMS (ESI) m/z: [M+Na $]^{+}$Calcd. for $\mathrm{C}_{18} \mathrm{H}_{28} \mathrm{O}_{2} \mathrm{SiNa}$ 327.1756; Found 327.1763.

$[\alpha]^{24}=-1.54\left(\mathrm{c}=0.00910, \mathrm{CH}_{2} \mathrm{Cl}_{2}\right)$

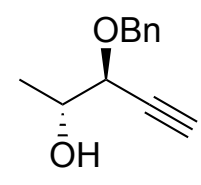

$(-)-17$

(2R,3S)-3-(benzyloxy)pent-4-yn-2-ol (-)-17

A solution of (-)-16 (1.14 g, $3.74 \mathrm{mmol})$ in THF $(36 \mathrm{~mL})$ was cooled to $0{ }^{\circ} \mathrm{C}$ and treated with tetrabutylammonium fluoride $(1.0 \mathrm{M}$ in $\mathrm{THF}, 4.90 \mathrm{~mL}, 4.90 \mathrm{mmol})$. The solution was warmed to $23{ }^{\circ} \mathrm{C}$ and stirred for 2 hours. Upon consumption of starting material, the solution was concentrated in vacuo and purification by flash column chromatography on silica gel $(30 \%$ ethyl acetate in hexanes) afforded (-)-17 (0.662 g, 93\%) as a slightly yellow oil. 
${ }^{1} \mathrm{H}$ NMR $\left(500 \mathrm{MHz}, \mathrm{CDCl}_{3}\right) \delta$ 7.38-7.28 (m, 5H), $4.87(\mathrm{~d}, \mathrm{~J}=11.7 \mathrm{~Hz}, 1 \mathrm{H}), 4.55(\mathrm{~d}, \mathrm{~J}=11.7 \mathrm{~Hz}$, $1 \mathrm{H}), 4.03(\mathrm{dd}, \mathrm{J}=3.9,2.1 \mathrm{~Hz}, 1 \mathrm{H}), 3.99-3.92(\mathrm{~m}, 1 \mathrm{H}), 2.53(\mathrm{~d}, \mathrm{~J}=2.1 \mathrm{~Hz}, 1 \mathrm{H}), 2.24(\mathrm{~d}, \mathrm{~J}=5.0$ $\mathrm{Hz}, 1 \mathrm{H}), 1.28(\mathrm{~d}, \mathrm{~J}=6.4 \mathrm{~Hz}, 3 \mathrm{H})$.

${ }^{13} \mathrm{C} \mathrm{NMR}\left(125 \mathrm{MHz}, \mathrm{CDCl}_{3}\right) \delta 137.3,128.5,128.1,127.9,79.6,75.9,73.2,70.9,69.2,18.1$.

LRMS (ESI) m/z: [M+Na] $]^{+}$Calcd. for $\mathrm{C}_{12} \mathrm{H}_{14} \mathrm{O}_{2} \mathrm{Na}$ 213.09; Found 213.71 .

HRMS (ESI) m/z: [M+Na] $]^{+}$Calcd. for $\mathrm{C}_{12} \mathrm{H}_{14} \mathrm{O}_{2} \mathrm{Na}$ 213.0891; Found 213.0892.

$[\alpha]^{24} \mathrm{D}=-26.77\left(\mathrm{c}=0.0124, \mathrm{CH}_{2} \mathrm{Cl}_{2}\right)$

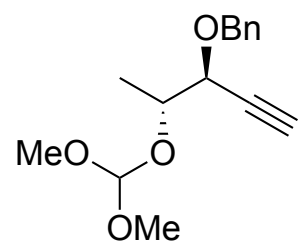

$(-)-1$

(2R,3S)-2-(dimethoxymethoxy)-3-(benzyloxy)pent-4-yne (-)-1

A solution of trimethyl orthoformate $(34.6 \mathrm{~mL}, 315 \mathrm{mmol})$ in anhydrous $\mathrm{CH}_{2} \mathrm{Cl}_{2}(9.34 \mathrm{~mL})$ was treated with solid magnesium chloride $(0.188 \mathrm{~g}, 1.97 \mathrm{mmol})$ that had been dried in vacuo overnight at $130{ }^{\circ} \mathrm{C}$. After being stirred for $20 \mathrm{~min}$, a solution of (-)-17 $(1.5 \mathrm{~g}, 7.88 \mathrm{mmol})$ in anhydrous $\mathrm{CH}_{2} \mathrm{Cl}_{2}(14 \mathrm{~mL})$ was added into the mixture. The reaction was stirred at $23{ }^{\circ} \mathrm{C}$ for 48 hours and then quenched with $0.68 \mathrm{M} \mathrm{NaOH}$ aq. solution $(10 \mathrm{~mL})$. The resulting mixture was diluted with $\mathrm{H}_{2} \mathrm{O}(50 \mathrm{~mL})$ and extracted with $\mathrm{CH}_{2} \mathrm{Cl}_{2}(5 \mathrm{x})$. The pooled organic layers were washed with $\mathrm{H}_{2} \mathrm{O}$ $(2 \mathrm{x})$, brine (1x), dried over $\mathrm{Na}_{2} \mathrm{SO}_{4}$, filtered, and concentrated in vacuo at $20^{\circ} \mathrm{C}$. Purification by flash column chromatography on neutralized silica gel (20\% ethyl acetate in hexanes) afforded ()-1 (1.79 $\mathrm{g}, 86 \%)$ as a colorless oil.

${ }^{1} \mathrm{H}$ NMR $\left(500 \mathrm{MHz}, \mathrm{C}_{6} \mathrm{D}_{6}\right) \delta 7.32-7.06(\mathrm{~m}, 5 \mathrm{H}), 5.21(\mathrm{~s}, 1 \mathrm{H}), 4.79(\mathrm{~d}, J=11.9 \mathrm{~Hz}, 1 \mathrm{H}), 4.41(\mathrm{~d}, J$ $=11.9 \mathrm{~Hz}, 1 \mathrm{H}), 4.12(\mathrm{dd}, J=4.1,2.1 \mathrm{~Hz}, 1 \mathrm{H}), 4.09-4.03(\mathrm{~m}, 1 \mathrm{H}), 3.22(\mathrm{~s}, 3 \mathrm{H}), 3.16(\mathrm{~s}, 3 \mathrm{H}), 2.03$ $(\mathrm{d}, J=2.0 \mathrm{~Hz}, 1 \mathrm{H}), 1.36(\mathrm{~d}, J=6.4 \mathrm{~Hz}, 3 \mathrm{H})$.

${ }^{13} \mathrm{C}$ NMR $\left(125 \mathrm{MHz}, \mathrm{C}_{6} \mathrm{D}_{6}\right) \delta 137.9,128.2,127.9,127.8,127.6,113.9,80.7,74.9,72.4,70.8,51.1$, $50.3,16.5$.

LRMS (ESI) m/z: [M+Na] ${ }^{+}$Calcd. for $\mathrm{C}_{15} \mathrm{H}_{20} \mathrm{O}_{4} \mathrm{Na}$ 287.13; Found 287.50.

HRMS (ESI) m/z: [M+Na] ${ }^{+}$Calcd. for $\mathrm{C}_{15} \mathrm{H}_{20} \mathrm{O}_{4} \mathrm{Na}$ 287.1259; Found 287.1265.

$[\alpha]^{24}{ }_{\mathrm{D}}=-2.69\left(\mathrm{c}=0.0783, \mathrm{CH}_{2} \mathrm{Cl}_{2}\right.$ 


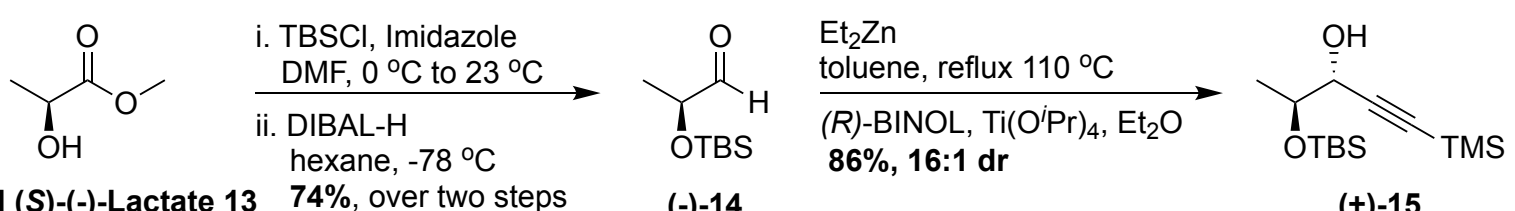

Methyl (S)-(-)-Lactate $13 \quad 74 \%$, over two steps $\quad(-)-14$

$(+)-15$

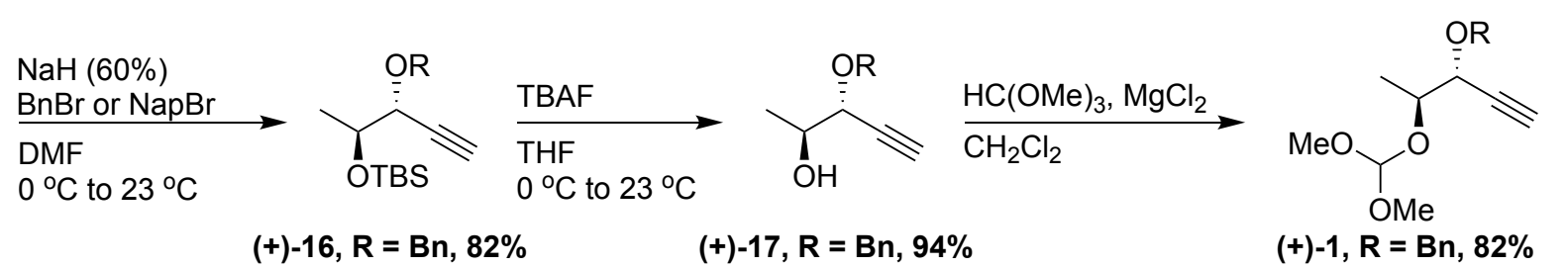

$(+)-18, R=$ Nap, $79 \%$

$(+)-19, R=$ Nap, $96 \%$

$(+)-2, R=$ Nap, $83 \%$

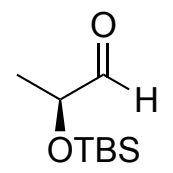

$(-)-14$

\section{(S)-2-((tert-butyldimethylsilyl)oxy)propanal (-)-14}

i. The title compound was prepared following the same two step procedure used for compound $(+)-14^{1,2}$. Methyl $(S)-(-)$-lactate $(10.0 \mathrm{~mL}, 106 \mathrm{mmol})$ and imidazole $(10.8 \mathrm{~g}, 159 \mathrm{mmol})$ were dissolved in DMF $(60 \mathrm{~mL})$ and the solution was cooled to $0{ }^{\circ} \mathrm{C}$ before adding $\mathrm{TBSCl}(23.9 \mathrm{~g}, 159$ mmol). The reaction was stirred at $0{ }^{\circ} \mathrm{C}$ for 15 minutes and then removed from the ice bath and stirred at $23{ }^{\circ} \mathrm{C}$. After 1 hour, the reaction was quenched with methanol $(20 \mathrm{~mL})$, diluted with $\mathrm{H}_{2} \mathrm{O}$ $(400 \mathrm{~mL})$, and extracted with $\mathrm{CH}_{2} \mathrm{Cl}_{2}(3 \mathrm{x})$. The pooled organic layers were washed with $1 \mathrm{M} \mathrm{LiCl}$ $(3 \mathrm{x})$, brine $(1 \mathrm{x})$, dried over $\mathrm{Na}_{2} \mathrm{SO}_{4}$, filtered, and concentrated in vacuo at $25{ }^{\circ} \mathrm{C}$. The resulting colorless oil was carried on crude.

ii. A portion of the crude product $(5.0 \mathrm{~g})$ from the TBS protection was dissolved in anhydrous hexanes $(45 \mathrm{~mL})$ and cooled to $-78{ }^{\circ} \mathrm{C}$. A solution of DIBAL-H $(1.0 \mathrm{M}$ in hexanes, $29.8 \mathrm{~mL}, 29.8$ mmol) that was cooled to $-78{ }^{\circ} \mathrm{C}$ was added dropwise over $10 \mathrm{~min}$ via canula. The reaction was stirred at $-78{ }^{\circ} \mathrm{C}$ for 2.5 hours, during which time it became progressively more opaque as the reaction progressed. Upon consumption of the starting material, the reaction was quenched with $\mathrm{MeOH}(5 \mathrm{~mL})$ at $-78{ }^{\circ} \mathrm{C}$ and then promptly removed from the $-78{ }^{\circ} \mathrm{C}$ bath. After stirring the solution for 15 minutes at $23{ }^{\circ} \mathrm{C}$, sat. aq. Rochelle's salt $(45 \mathrm{~mL})$ was added and the mixture was stirred vigorously for two hours. The resulting biphasic mixture was separated, and the aqueous layer was extracted with hexanes $(5 x)$. The pooled organic layers were washed with $\mathrm{H}_{2} \mathrm{O}(1 \mathrm{x})$, brine (1x), dried over $\mathrm{Na}_{2} \mathrm{SO}_{4}$, filtered, and concentrated in vacuo at $20{ }^{\circ} \mathrm{C}$. Purification by flash column chromatography on silica gel (30 to $40 \% \mathrm{CH}_{2} \mathrm{Cl}_{2}$ in hexanes) afforded compound (-)-14 ( $3.19 \mathrm{~g}, 74 \%$ over two steps) as a colorless oil. The aldehyde was noted to readily evaporate on high vacuum and was dried in a vacuum desiccator over 8 mesh Drierite. The spectroscopic data was in good agreement with previously reported values. ${ }^{4}$

${ }^{1} \mathrm{H}$ NMR $\left(500 \mathrm{MHz}, \mathrm{CDCl}_{3}\right) \delta 9.62(\mathrm{~d}, J=1.1 \mathrm{~Hz}, 1 \mathrm{H}), 4.10(\mathrm{qd}, J=6.8,1.2 \mathrm{~Hz}, 1 \mathrm{H}), 1.28(\mathrm{~d}, J$ $=6.9 \mathrm{~Hz}, 3 \mathrm{H}), 0.92(\mathrm{~s}, 9 \mathrm{H}), 0.11(\mathrm{~s}, 3 \mathrm{H}), 0.09(\mathrm{~s}, 3 \mathrm{H})$. 
${ }^{13} \mathrm{C}$ NMR $\left(125 \mathrm{MHz}, \mathrm{CDCl}_{3}\right) \delta$ 204.2, 73.9, 73.8, 25.8, 25.7, 18.5, 18.5, 18.4, 18.2, -4.8.

LRMS (ESI) m/z: [M+Na $]^{+}$Calcd. for $\mathrm{C}_{9} \mathrm{H}_{20} \mathrm{O}_{2} \mathrm{SiNa} 211.33$; Found 211.67 .

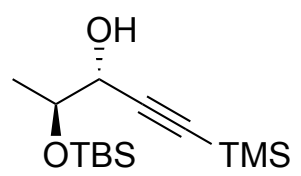

$(+)-15$

\section{(2S,3R)-2-((tert-butyldimethylsilyl)oxy)-5-(trimethylsilyl)pent-4-yn-3-ol (+)-15}

The title compound was prepared following the same procedure used for compound (-)-15 $\mathbf{5}^{3}$ A solution of trimethylsilyl acetylene $(4.41 \mathrm{~mL}, 31.9 \mathrm{mmol})$ in anhydrous toluene $(31.1 \mathrm{~mL})$ was treated dropwise with diethylzinc $(1.5 \mathrm{M}$ in toluene, $21.2 \mathrm{~mL}, 31.9 \mathrm{mmol})$ and the resulting solution was refluxed for 2.5 hours, resulting in the formation of a thick, grey precipitate. After cooling the reaction to $23{ }^{\circ} \mathrm{C}$, the mixture was diluted with anhydrous diethyl ether $(92 \mathrm{~mL})$ and treated with $(R)$-BINOL $(0.912 \mathrm{~g}, 3.19 \mathrm{mmol})$ and $\mathrm{Ti}\left(\mathrm{O}^{i} \mathrm{Pr}\right)_{4}(2.36 \mathrm{~mL}, 7.96 \mathrm{mmol})$. After vigorous stirring for 1.5 hours, a solution of compound (-)-14 (1.50 g, $7.96 \mathrm{mmol})$ in anhydrous diethyl ether $(21 \mathrm{~mL})$ was added. After stirring overnight at $23{ }^{\circ} \mathrm{C}$, the reaction was cooled to $0{ }^{\circ} \mathrm{C}$ and then quenched with $1 \mathrm{M}$ aq. tartaric acid $(150 \mathrm{~mL})$. The resulting mixture was stirred at $23{ }^{\circ} \mathrm{C}$ for 30 min and then diluted with $\mathrm{H}_{2} \mathrm{O}(200 \mathrm{~mL})$. The layers were separated, and the aqueous layer was extracted with $\mathrm{Et}_{2} \mathrm{O}(4 \mathrm{x})$. The pooled organic layers were washed with $\mathrm{H}_{2} \mathrm{O}(1 \mathrm{x})$, sat. aq. sodium bicarbonate $(1 \mathrm{x})$, brine $(1 \mathrm{x})$, dried over $\mathrm{Na}_{2} \mathrm{SO}_{4}$, filtered, and concentrated in vacuo at $25{ }^{\circ} \mathrm{C}$. Purification by flash column chromatography on silica gel (60\% dichloromethane in hexanes) afforded compound $(+)-15(1.96 \mathrm{~g}, 86 \%, 16: 1 \mathrm{dr})$ as a white solid. The spectroscopic data is in good agreement with previously reported values. ${ }^{3}$

${ }^{1} \mathrm{H}$ NMR (500 MHz, $\left.\mathrm{CDCl}_{3}\right) \delta 4.24-4.22(\mathrm{~m} \mathrm{1H}), 3.90(\mathrm{qd}, J=6.2,3.9 \mathrm{~Hz}, 1 \mathrm{H}), 2.31(\mathrm{~d}, J=5.5$ $\mathrm{Hz}, 1 \mathrm{H}), 1.22$ (d, $J=6.2 \mathrm{~Hz}, 3 \mathrm{H}), 0.90$ (s, 9H), 0.17 (s, 9H), 0.10 (s, 3H), 0.09 (s, 3H).

${ }^{13} \mathrm{C}$ NMR $\left(125 \mathrm{MHz}, \mathrm{CDCl}_{3}\right) \delta 103.7,90.8,70.9,67.4,25.8,18.9,18.0,-0.2,-4.4$.

LRMS (ESI) m/z: [M+Na] $]^{+}$Calcd. for $\mathrm{C}_{14} \mathrm{H}_{30} \mathrm{O}_{2} \mathrm{Si}_{2} \mathrm{Na}$ 309.55; Found 310.40 .

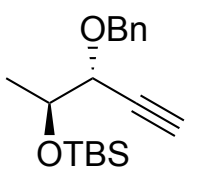

$(+)-16$

(2S,3R)-2-(tert-buytldimethylsilyloxy)-3-(benzyloxy)-pent-4-yne (+)-16

The title compound was prepared following the same procedure used for compound (-)-16. A suspension of sodium hydride $(60 \%$ in mineral oil, $0.736 \mathrm{~g}, 18.4 \mathrm{mmol})$ in DMF $(24 \mathrm{~mL})$ was cooled to $0{ }^{\circ} \mathrm{C}$ and treated with a solution of $(+)-15(1.20 \mathrm{~g}, 4.19 \mathrm{mmol})$ in DMF $(27 \mathrm{~mL})$. After 
stirring at $0{ }^{\circ} \mathrm{C}$ for $10 \mathrm{~min}$, benzyl bromide $(2.19 \mathrm{~mL}, 18.4 \mathrm{mmol})$ was added dropwise and the resulting mixture was warmed from $0{ }^{\circ} \mathrm{C}$ to $23{ }^{\circ} \mathrm{C}$ overnight. The reaction was then quenched with sat. aq. $\mathrm{NH}_{4} \mathrm{Cl}(30 \mathrm{~mL})$ at $23{ }^{\circ} \mathrm{C}$ and the resulting mixture was diluted with $\mathrm{H}_{2} \mathrm{O}(400 \mathrm{~mL})$ and extracted with $\mathrm{Et}_{2} \mathrm{O}(4 \mathrm{x})$. The pooled organic layers were washed with $\mathrm{H}_{2} \mathrm{O}(2 \mathrm{x}), 1 \mathrm{M} \mathrm{LiCl}(2 \mathrm{x})$, brine (1x), dried over $\mathrm{Na}_{2} \mathrm{SO}_{4}$, filtered, and concentrated in vacuo at $25{ }^{\circ} \mathrm{C}$. Purification by flash column chromatography on silica gel (30\% dichloromethane in hexanes) afforded compound ( + )$16(1.06 \mathrm{~g}, 82 \%)$ as a slightly yellow oil.

${ }^{1} \mathrm{H}$ NMR $\left(500 \mathrm{MHz}, \mathrm{CDCl}_{3}\right) \delta$ 7.38-7.26 (m, 5H), $4.83(\mathrm{~d}, \mathrm{~J}=12.0 \mathrm{~Hz}, 1 \mathrm{H}), 4.56(\mathrm{~d}, \mathrm{~J}=12.0 \mathrm{~Hz}$, $1 \mathrm{H}), 3.97-3.91(\mathrm{~m}, 1 \mathrm{H}), 3.89(\mathrm{dd}, \mathrm{J}=5.5,2.0 \mathrm{~Hz}, 1 \mathrm{H}), 2.43(\mathrm{~d}, \mathrm{~J}=2.0 \mathrm{~Hz}, 1 \mathrm{H}), 1.25(\mathrm{~d}, \mathrm{~J}=6.1$ $\mathrm{Hz}, 3 \mathrm{H}), 0.88$ (s, 9H), 0.07 (s, 3H, $0.06(\mathrm{~s}, 3 \mathrm{H})$.

${ }^{13} \mathrm{C} \mathrm{NMR}\left(125 \mathrm{MHz}, \mathrm{CDCl}_{3}\right) \delta 137.8,128.3,128.0,127.7,81.5,74.6,73.7,70.9,70.7,25.9,19.8$, $18.2,-4.6,-4.62$.

LRMS (ESI) m/z: [M+Na $]^{+}$Calcd. for $\mathrm{C}_{18} \mathrm{H}_{28} \mathrm{O}_{2} \mathrm{SiNa}$ 327.18; Found 327.93 .

HRMS (ESI) m/z: [M+Na] $]^{+}$Calcd. for $\mathrm{C}_{18} \mathrm{H}_{28} \mathrm{O}_{2} \mathrm{SiNa}$ 327.1756; Found 327.1759.

$[\alpha]^{24} \mathrm{D}=0.717\left(\mathrm{c}=0.0321, \mathrm{CH}_{2} \mathrm{Cl}_{2}\right)$

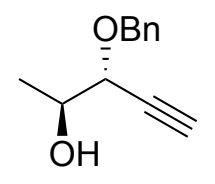

$(+)-17$

(2S,3R)-3-(benzyloxy)pent-4-yn-2-ol (+)-17

The title compound was prepared following the same procedure used for compound (-)-17. A solution of compound $(+)-16(1.14 \mathrm{~g}, 3.74 \mathrm{mmol})$ in THF $(36 \mathrm{~mL})$ was cooled to $0{ }^{\circ} \mathrm{C}$ and treated with tetrabutylammonium fluoride (1.0 M in THF, $4.68 \mathrm{~mL}, 4.86 \mathrm{mmol})$. The solution was warmed to $23{ }^{\circ} \mathrm{C}$ and stirred for 2 hours. Upon complete consumption of starting material, the solution was concentrated in vacuo and purification by flash column chromatography on silica gel (30\% ethyl acetate in hexanes) afforded compound $(+)-17(0.669 \mathrm{~g}, 94 \%)$ as a slightly yellow oil.

${ }^{1} \mathrm{H}$ NMR $\left(500 \mathrm{MHz}, \mathrm{CDCl}_{3}\right) \delta$ 7.40-7.28 (m, 5H), $4.87(\mathrm{~d}, J=11.7 \mathrm{~Hz}, 1 \mathrm{H}), 4.55(\mathrm{~d}, J=11.7 \mathrm{~Hz}$, $1 \mathrm{H}), 4.04-4.01(\mathrm{~m}, 1 \mathrm{H}), 3.99-3.92(\mathrm{~m}, 1 \mathrm{H}), 2.54(\mathrm{~d}, J=1.6 \mathrm{~Hz}, 1 \mathrm{H}), 2.30(\mathrm{~d}, J=4.9 \mathrm{~Hz}, 1 \mathrm{H}), 1.27$ $(\mathrm{d}, J=6.4 \mathrm{~Hz}, 3 \mathrm{H})$.

${ }^{13} \mathrm{C} \mathrm{NMR}\left(125 \mathrm{MHz}, \mathrm{CDCl}_{3}\right) \delta 137.3,128.5,128.2,127.9,79.5,76.0,73.2,70.9,69.2,18.1$.

LRMS (ESI) m/z: [M+Na] $]^{+}$Calcd. for $\mathrm{C}_{12} \mathrm{H}_{14} \mathrm{O}_{2} \mathrm{Na}$ 213.09; Found 213.40.

HRMS (ESI) m/z: [M+Na] $]^{+}$Calcd. for $\mathrm{C}_{12} \mathrm{H}_{14} \mathrm{O}_{2} \mathrm{Na} 213.0891$; Found 213.0897.

$[\alpha]^{24} \mathrm{D}=0.982\left(\mathrm{c}=0.0112, \mathrm{CH}_{2} \mathrm{Cl}_{2}\right.$ 


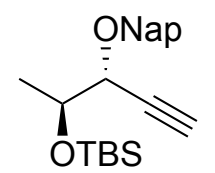

$(+)-18$

\section{(2S,3R)-2-(tert-buytldimethylsilyloxy)-3-(naphthyloxy)-pent-4-yne (+)-18}

A suspension of sodium hydride $(60 \%$ in mineral oil, $0.983 \mathrm{~g}, 24.6 \mathrm{mmol})$ in DMF $(32.6 \mathrm{~mL})$ was cooled to $0{ }^{\circ} \mathrm{C}$ and treated with a solution of $(+)-15(1.60 \mathrm{~g}, 5.58 \mathrm{mmol})$ in DMF $(18.1 \mathrm{~mL})$. After stirring at $0{ }^{\circ} \mathrm{C}$ for $10 \mathrm{~min}, 2$-(bromomethyl)naphthalene (NapBr) $(5.46 \mathrm{~g}, 24.6 \mathrm{mmol})$ was added as a solid and the resulting mixture was warmed from $0{ }^{\circ} \mathrm{C}$ to $23{ }^{\circ} \mathrm{C}$ overnight. The reaction was then quenched with sat. aq. $\mathrm{NH}_{4} \mathrm{Cl}(40 \mathrm{~mL})$ at $23{ }^{\circ} \mathrm{C}$ and the resulting mixture was diluted with $\mathrm{H}_{2} \mathrm{O}(400 \mathrm{~mL})$ and extracted with $\mathrm{Et}_{2} \mathrm{O}(4 \mathrm{x})$. The pooled organic layers were washed with $\mathrm{H}_{2} \mathrm{O}$ $(2 \mathrm{x}), 1 \mathrm{M} \mathrm{LiCl}(2 \mathrm{x})$, brine $(1 \mathrm{x})$, dried over $\mathrm{Na}_{2} \mathrm{SO}_{4}$, filtered, and concentrated in vacuo at $25{ }^{\circ} \mathrm{C}$. Purification by flash column chromatography on silica gel (30\% dichloromethane in hexanes) afforded compound $(+)-18(1.56 \mathrm{~g}, 79 \%)$ as a slightly yellow oil.

${ }^{1} \mathrm{H}$ NMR $\left(500 \mathrm{MHz}, \mathrm{CDCl}_{3}\right) \delta 7.87-7.43(\mathrm{~m}, 7 \mathrm{H}), 5.00(\mathrm{~d}, J=12.1 \mathrm{~Hz}, 1 \mathrm{H}), 4.74(\mathrm{~d}, J=12.1$ $\mathrm{Hz}, 1 \mathrm{H}), 4.02-3.98(\mathrm{~m}, 1 \mathrm{H}), 3.95(\mathrm{dd}, J=5.4,1.9 \mathrm{~Hz}, 1 \mathrm{H}), 2.48(\mathrm{~d}, J=1.9 \mathrm{~Hz}, 1 \mathrm{H}), 1.29(\mathrm{~d}, J=$ $6.0 \mathrm{~Hz}, 3 \mathrm{H}), 0.91(\mathrm{~s}, 9 \mathrm{H}), 0.10(\mathrm{~s}, 3 \mathrm{H}), 0.09(\mathrm{~s}, 3 \mathrm{H})$.

${ }^{13} \mathrm{C}$ NMR $\left(125 \mathrm{MHz}, \mathrm{CDCl}_{3}\right) \delta 135.3,133.3,133.1,128.1,127.9,127.7,126.9,126.1,126.1$, $125.9,81.5,74.7,73.8,71.0,70.7,29.7,25.9,19.9,18.2,-4.5,-4.6$.

LRMS (ESI) m/z: $[\mathrm{M}+\mathrm{Na}]^{+}$Calcd. for $\mathrm{C}_{22} \mathrm{H}_{30} \mathrm{O}_{2} \mathrm{SiNa} 377.19$; Found 378.37 .

HRMS (ESI) m/z: [M+Na $]^{+}$Calcd. for $\mathrm{C}_{22} \mathrm{H}_{30} \mathrm{O}_{2} \mathrm{SiNa}$ 377.1913; Found 377.1915.

$[\alpha]^{24}=33.1\left(\mathrm{c}=0.0486, \mathrm{CH}_{2} \mathrm{Cl}_{2}\right)$

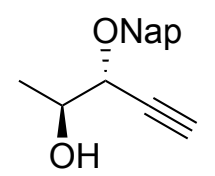

$(+)-19$

\section{(2S,3R)-3-(naphthyloxy)pent-4-yn-2-ol (+)-19}

The title compound was prepared following the same procedure used for compound (-)-17. A solution of compound (+)-18 $(1.21 \mathrm{~g}, 3.41 \mathrm{mmol})$ in THF $(38.1 \mathrm{~mL})$ was cooled to $0{ }^{\circ} \mathrm{C}$ and treated with tetrabutylammonium fluoride (1.0 M in THF, $4.43 \mathrm{~mL}, 4.43 \mathrm{mmol})$. The solution was warmed to $23{ }^{\circ} \mathrm{C}$ and stirred for 2 hours. Upon complete consumption of starting material, the solution was concentrated in vacuo and purification by flash column chromatography on silica gel (30\% ethyl acetate in hexanes) afforded compound $(+)-19(0.787 \mathrm{~g}, 96 \%)$ as a slightly yellow oil. 
${ }^{1} \mathrm{H}$ NMR $\left(500 \mathrm{MHz}, \mathrm{CDCl}_{3}\right) \delta 7.87-7.43(\mathrm{~m}, 7 \mathrm{H}), 5.02(\mathrm{~d}, J=11.8 \mathrm{~Hz}, 1 \mathrm{H}), 4.71(\mathrm{~d}, J=11.8$ $\mathrm{Hz}, 1 \mathrm{H}), 4.08-4.03(\mathrm{~m}, 1 \mathrm{H}), 4.01-3.94(\mathrm{~m}, 1 \mathrm{H}), 2.56(\mathrm{~d}, J=1.9 \mathrm{~Hz}, 1 \mathrm{H}), 2.34(\mathrm{~d}, J=4.6 \mathrm{~Hz}$, $1 \mathrm{H}), 1.28(\mathrm{~d}, J=6.4 \mathrm{~Hz}, 3 \mathrm{H})$.

${ }^{13} \mathrm{C}$ NMR $\left(125 \mathrm{MHz}, \mathrm{CDCl}_{3}\right) \delta 134.7,133.3,133.1,128.3,127.9,127.7,127.1,126.2,126.1$, 126.0, 79.6, 76.1 73.2, 71.1, 69.2, 18.1 .

LRMS (ESI) m/z: [M+Na] $]^{+}$Calcd. for $\mathrm{C}_{16} \mathrm{H}_{16} \mathrm{O}_{2} \mathrm{Na}$ 263.10; Found 263.45 .

HRMS (ESI) m/z: [M+Na] $]^{+}$Calcd. for $\mathrm{C}_{16} \mathrm{H}_{16} \mathrm{O}_{2} \mathrm{Na}$ 263.1048; Found 263.1051 .

$[\alpha]^{24} \mathrm{D}=6.09\left(\mathrm{c}=0.00460, \mathrm{CH}_{2} \mathrm{Cl}_{2}\right)$

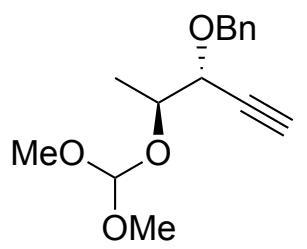

$(+)-1$

(2S,3R)-2-(dimethoxymethoxy)-3-(benzyloxy)pent-4-yne (+)-1

The title compound was prepared following the same procedure used for compound (-)-1. A solution of trimethyl orthoformate $(34.6 \mathrm{~mL}, 315 \mathrm{mmol})$ in anhydrous $\mathrm{CH}_{2} \mathrm{Cl}_{2}(9.34 \mathrm{~mL})$ was treated with solid magnesium chloride $(0.188 \mathrm{~g}, 1.97 \mathrm{mmol})$ that had been dried in vacuo overnight at $130{ }^{\circ} \mathrm{C}$. After being stirred for $20 \mathrm{~min}$, a solution of $(+)-17(1.50 \mathrm{~g}, 7.88 \mathrm{mmol})$ in anhydrous $\mathrm{CH}_{2} \mathrm{Cl}_{2}(14 \mathrm{~mL})$ was added into the mixture. The reaction was stirred at $23{ }^{\circ} \mathrm{C}$ for 48 hours and then quenched with $0.68 \mathrm{M} \mathrm{NaOH}$ aq. solution $(10 \mathrm{~mL})$. The resulting mixture was diluted with $\mathrm{H}_{2} \mathrm{O}(50 \mathrm{~mL})$ and extracted with $\mathrm{CH}_{2} \mathrm{Cl}_{2}(5 \mathrm{x})$. The pooled organic layers were washed with $\mathrm{H}_{2} \mathrm{O}$ $(2 \mathrm{x})$, brine $(1 \mathrm{x})$, and then dried over $\mathrm{Na}_{2} \mathrm{SO}_{4}$, filtered, and concentrated in vacuo at $20{ }^{\circ} \mathrm{C}$. Purification by flash column chromatography on neutralized silica gel $(20 \%$ ethyl acetate in hexanes) afforded compound $(+)-1(1.71 \mathrm{~g}, 82 \%)$ as a colorless oil.

${ }^{1} \mathrm{H}$ NMR $\left(500 \mathrm{MHz}, \mathrm{C}_{6} \mathrm{D}_{6}\right) \delta$ 7.32-7.06 (m, 5H), $5.21(\mathrm{~s}, 1 \mathrm{H}), 4.79(\mathrm{~d}, J=11.9 \mathrm{~Hz}, 1 \mathrm{H}), 4.41(\mathrm{~d}, J$ $=11.9 \mathrm{~Hz}, 1 \mathrm{H}), 4.12(\mathrm{dd}, J=4.1,2.1 \mathrm{~Hz}, 1 \mathrm{H}), 4.09-4.03(\mathrm{~m}, 1 \mathrm{H}), 3.22(\mathrm{~s}, 3 \mathrm{H}), 3.16(\mathrm{~s}, 3 \mathrm{H}), 2.03$ (d, $J=2.0 \mathrm{~Hz}, 1 \mathrm{H}), 1.36(\mathrm{~d}, J=6.4 \mathrm{~Hz}, 3 \mathrm{H})$.

${ }^{13} \mathrm{C}$ NMR $\left(125 \mathrm{MHz}, \mathrm{C}_{6} \mathrm{D}_{6}\right) \delta 137.9,128.2,127.9,127.8,127.6,113.9,80.7,74.9,72.4,70.8,51.1$, $50.3,16.5$.

LRMS (ESI) m/z: [M+Na] $]^{+}$Calcd. for $\mathrm{C}_{15} \mathrm{H}_{20} \mathrm{O}_{4} \mathrm{Na} 287.13$; Found 287.96 .

HRMS (ESI) m/z: [M+Na] $]^{+}$Calcd. for $\mathrm{C}_{15} \mathrm{H}_{20} \mathrm{O}_{4} \mathrm{Na}$ 287.1259; Found 287.1260.

$[\alpha]^{24} \mathrm{D}=1.98\left(\mathrm{c}=0.102, \mathrm{CH}_{2} \mathrm{Cl}_{2}\right)$ 


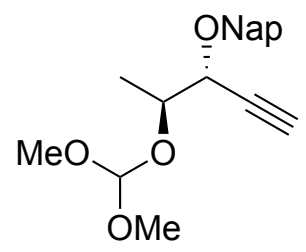

$(+)-2$

\section{(2S,3R)-2-(dimethoxymethoxy)-3-(naphthyloxy)pent-4-yne (+)-2}

The title compound was prepared following the same procedure used for compound (-)-1. A solution of trimethyl orthoformate $(27.4 \mathrm{~mL}, 250 \mathrm{mmol})$ in anhydrous $\mathrm{CH}_{2} \mathrm{Cl}_{2}(9.5 \mathrm{~mL})$ was treated with solid magnesium chloride $(0.149 \mathrm{~g}, 1.56 \mathrm{mmol})$ that had been dried in vacuo overnight at 130 ${ }^{\circ} \mathrm{C}$. After being stirred for $20 \mathrm{~min}$, a solution of $(+)-19(1.5 \mathrm{~g}, 6.24 \mathrm{mmol})$ in anhydrous $\mathrm{CH}_{2} \mathrm{Cl}_{2}$ $(14 \mathrm{~mL})$ was added into the mixture. The reaction was stirred at $23{ }^{\circ} \mathrm{C}$ for 48 hours and then quenched with $0.68 \mathrm{M} \mathrm{NaOH}$ aq. solution $(10 \mathrm{~mL})$. The resulting mixture was diluted with $\mathrm{H}_{2} \mathrm{O}$ $(50 \mathrm{~mL})$ and extracted with $\mathrm{CH}_{2} \mathrm{Cl}_{2}(5 \mathrm{x})$. The pooled organic layers were washed with $\mathrm{H}_{2} \mathrm{O}(2 \mathrm{x})$, brine $(1 \mathrm{x})$, and then dried over $\mathrm{Na}_{2} \mathrm{SO}_{4}$, filtered, and concentrated in vacuo at $20{ }^{\circ} \mathrm{C}$. Purification by flash column chromatography on neutralized silica gel (20\% ethyl acetate in hexanes) afforded compound $(+)-2(1.63 \mathrm{~g}, 83 \%)$ as a colorless oil.

${ }^{1} \mathrm{H}$ NMR $\left(500 \mathrm{MHz}, \mathrm{C}_{6} \mathrm{D}_{6}\right) \delta$ 7.74-7.23 (m, 7H), $5.21(\mathrm{~s}, 1 \mathrm{H}), 4.93(\mathrm{~d}, J=12.0 \mathrm{~Hz}, 1 \mathrm{H}), 4.58(\mathrm{~d}, J$ $=12.0 \mathrm{~Hz}, 1 \mathrm{H}), 4.19(\mathrm{dd}, J=4.1,2.1 \mathrm{~Hz}, 1 \mathrm{H}), 4.12-4.07(\mathrm{~m}, 1 \mathrm{H}), 3.21(\mathrm{~s}, 3 \mathrm{H}), 3.15(\mathrm{~s}, 3 \mathrm{H}), 2.06$ $(\mathrm{d}, J=2.1 \mathrm{~Hz}, 1 \mathrm{H}), 1.40(\mathrm{~d}, J=6.4 \mathrm{~Hz}, 3 \mathrm{H})$.

${ }^{13} \mathrm{C}$ NMR $\left(125 \mathrm{MHz}, \mathrm{C}_{6} \mathrm{D}_{6}\right) \delta 135.4,133.5,133.2,128.1,127.9,127.8,127.6,126.7,125.9,125.9$, $125.7,113.9,80.7,74.9,72.4,72.4,70.9,51.1,50.3,16.5$.

LRMS (ESI) m/z: [M+Na] $]^{+}$Calcd. for $\mathrm{C}_{19} \mathrm{H}_{22} \mathrm{O}_{4} \mathrm{Na} 337.14$; Found 337.81 .

HRMS (ESI) m/z: [M+Na] $]^{+}$Calcd. for $\mathrm{C}_{19} \mathrm{H}_{22} \mathrm{O}_{4} \mathrm{Na}$ 337.1416; Found 337.1418.

$[\alpha]^{24} \mathrm{D}=51.4\left(\mathrm{c}=0.0483, \mathrm{CH}_{2} \mathrm{Cl}_{2}\right)$

S2.2 Preparation of 1,2-syn-substituted orthoesters (-)-3 and (+)-3.
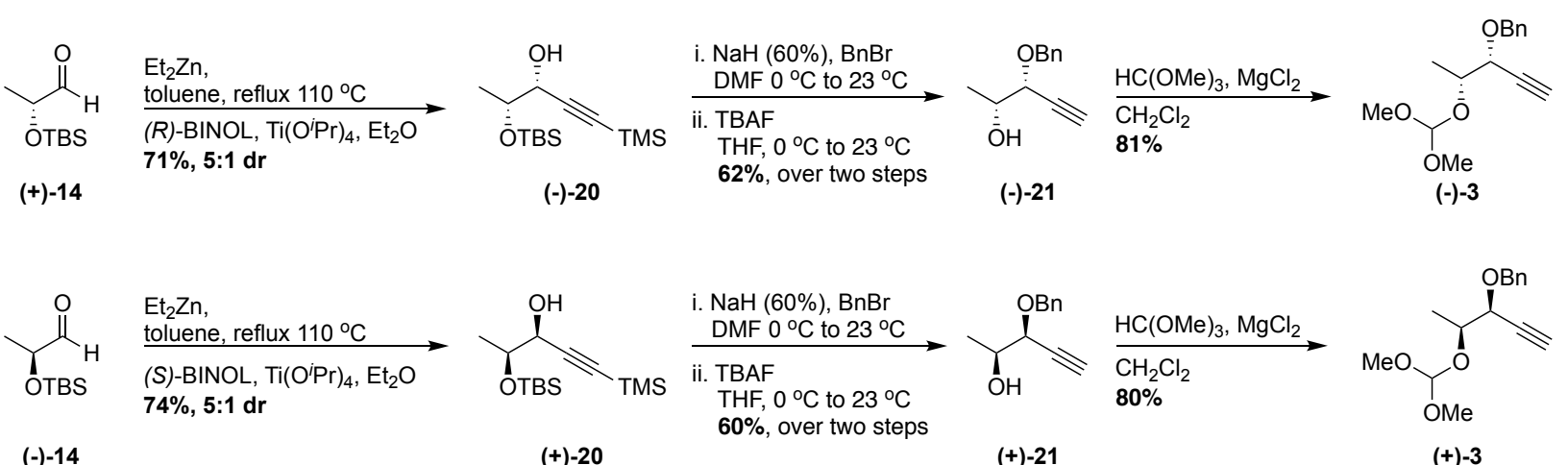

$(-)-14$

(+)-20

(+)-21

(+)-3 


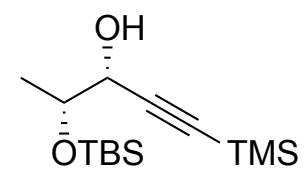

$(-)-20$

(2R,3R)-2-((tert-butyldimethylsilyl)oxy)-5-(trimethylsilyl)pent-4-yn-3-ol (-)-20

The title compound was prepared following the same procedure used for compound (-)-15 $\mathbf{5}^{3}$ A solution of trimethylsilyl acetylene $(4.41 \mathrm{~mL}, 31.9 \mathrm{mmol})$ in anhydrous toluene $(31.1 \mathrm{~mL})$ was treated dropwise with diethylzinc $(1.5 \mathrm{M}$ in toluene, $21.2 \mathrm{~mL}, 31.9 \mathrm{mmol})$ and the solution was refluxed for 2.5 hours, resulting in the formation of a thick, grey precipitate. The solution was then cooled to $23{ }^{\circ} \mathrm{C}$ and diluted with anhydrous diethyl ether $(92 \mathrm{~mL})$. The mixture was treated with $(R)$-BINOL $(0.912 \mathrm{~g}, 3.19 \mathrm{mmol})$ and $\mathrm{Ti}\left(\mathrm{O}^{i} \mathrm{Pr}\right)_{4}(2.36 \mathrm{~mL}, 7.96 \mathrm{mmol})$ and stirred vigorously for 1.5 hours at $23{ }^{\circ} \mathrm{C}$ before a solution of compound $(+)-14(1.50 \mathrm{~g}, 7.96 \mathrm{mmol})$ in anhydrous diethyl ether $(21 \mathrm{~mL})$ was added to the mixture. After stirring overnight at $23{ }^{\circ} \mathrm{C}$, the reaction was cooled to $0{ }^{\circ} \mathrm{C}$ and then quenched with $1 \mathrm{M}$ aq. tartaric acid $(150 \mathrm{~mL})$. The resulting mixture was stirred at $23{ }^{\circ} \mathrm{C}$ for $30 \mathrm{~min}$ and then diluted with $\mathrm{H}_{2} \mathrm{O}(200 \mathrm{~mL})$. The layers were separated, and the aqueous layer was extracted with $\mathrm{Et}_{2} \mathrm{O}(4 \mathrm{x})$. The pooled organic layers were washed with $\mathrm{H}_{2} \mathrm{O}$ (1x), sat. aq. sodium bicarbonate (1x), brine (1x), dried over $\mathrm{Na}_{2} \mathrm{SO}_{4}$, filtered, and concentrated in vacuo at $25^{\circ} \mathrm{C}$. Purification by flash column chromatography on silica gel $(60 \%$ dichloromethane in hexanes) afforded compound (-)-20 (1.62, 71\%,5:1) as a clear oil. The spectroscopic data is in good agreement with previously reported values. ${ }^{3}$

Major Diastereomer:

${ }^{1} \mathrm{H}$ NMR $\left(500 \mathrm{MHz}, \mathrm{CDCl}_{3}\right) \delta 4.06(\mathrm{dd}, \mathrm{J}=6.1,5.1 \mathrm{~Hz}, 1 \mathrm{H}), 3.90-3.84(\mathrm{~m}, 1 \mathrm{H}), 2.59(\mathrm{~d}, \mathrm{~J}=6.2$ $\mathrm{Hz}, 1 \mathrm{H}), 1.22$ (d, J = 6.2 Hz, 3H), 0.91 (s, 9H), 0.17 (s, 9H), 0.13 (s, 3H), 0.11 (s, 3H).

${ }^{13} \mathrm{C} \mathrm{NMR}\left(125 \mathrm{MHz}, \mathrm{CDCl}_{3}\right) \delta 104.8,89.8,71.9,67.7,25.8,20.2,18.2,-0.2,-4.4,-4.7$.

LRMS (ESI) m/z: [M+Na] $]^{+}$Calcd. for $\mathrm{C}_{14} \mathrm{H}_{30} \mathrm{O}_{2} \mathrm{Si}_{2} \mathrm{Na}$ 309.55; Found 309.69.

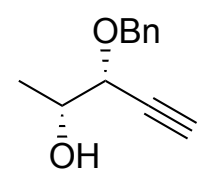

$(-)-21$

(2R,3R)-3-(benzyloxy)pent-4-yn-2-ol (-)-21

i. The title compound was prepared over two steps following a combination of the procedures used for compounds (-)-16 and (-)-17. A suspension of sodium hydride $(60 \%$ in mineral oil, $0.866 \mathrm{~g}$, $21.7 \mathrm{mmol})$ in DMF $(28.4 \mathrm{~mL})$ was cooled to $0{ }^{\circ} \mathrm{C}$ and treated with a solution of (-)-20 $(1.41 \mathrm{~g}$, $4.92 \mathrm{mmol})$ in DMF $(31.7 \mathrm{~mL})$. After stirring at $0{ }^{\circ} \mathrm{C}$ for $10 \mathrm{~min}$, benzyl bromide $(2.57 \mathrm{~mL}, 21.7$ mmol) was added dropwise and the resulting mixture was warmed from $0{ }^{\circ} \mathrm{C}$ to $23{ }^{\circ} \mathrm{C}$ overnight. 
The reaction was then quenched with sat. aq. $\mathrm{NH}_{4} \mathrm{Cl}(30 \mathrm{~mL})$ at $23{ }^{\circ} \mathrm{C}$ and the resulting mixture was diluted with $\mathrm{H}_{2} \mathrm{O}(400 \mathrm{~mL})$ and extracted with $\mathrm{Et}_{2} \mathrm{O}(4 \mathrm{x})$. The pooled organic layers were washed with $\mathrm{H}_{2} \mathrm{O}(2 \mathrm{x}), 1 \mathrm{M} \mathrm{LiCl}(2 \mathrm{x})$, brine $(1 \mathrm{x})$, dried over $\mathrm{Na}_{2} \mathrm{SO}_{4}$, filtered, and concentrated in vacuo at $25^{\circ} \mathrm{C}$.

ii. The crude residue was dissolved in THF $(34.3 \mathrm{~mL})$, cooled to $0{ }^{\circ} \mathrm{C}$, and treated with tetrabutylammonium fluoride $(1.0 \mathrm{M}$ in THF, $4.65 \mathrm{~mL}, 4.65 \mathrm{mmol})$. The resulting reaction was warmed to $23{ }^{\circ} \mathrm{C}$ and stirred for 2 hours. Upon complete consumption of starting material, the reaction was concentrated in vacuo at $25{ }^{\circ} \mathrm{C}$. Purification by flash column chromatography on silica gel (30\% dichloromethane in hexanes) afforded compound (-)-21 (0.572 g, 62\% yield over two steps) as a slightly yellow oil.

${ }^{1} \mathrm{H}$ NMR $\left(500 \mathrm{MHz}, \mathrm{CDCl}_{3}\right) \delta$ 7.39-7.28 (m, 5H), $4.87(\mathrm{~d}, \mathrm{~J}=11.4 \mathrm{~Hz}, 1 \mathrm{H}), 4.53(\mathrm{~d}, \mathrm{~J}=11.5 \mathrm{~Hz}$, $1 \mathrm{H}), 3.92-3.86(\mathrm{~m}, 2 \mathrm{H}), 2.60(\mathrm{~s}, 1 \mathrm{H}), 2.52(\mathrm{~d}, J=1.7 \mathrm{~Hz}, 1 \mathrm{H}), 1.29(\mathrm{~d}, \mathrm{~J}=5.9 \mathrm{~Hz}, 3 \mathrm{H})$.

${ }^{13} \mathrm{C} \mathrm{NMR}\left(125 \mathrm{MHz}, \mathrm{CDCl}_{3}\right) \delta 137.2,128.5,128.2,128.0,80.1,75.7,74.0,71.1,69.8,18.2$.

LRMS (ESI) m/z: [M+Na] ${ }^{+}$Calcd. for $\mathrm{C}_{12} \mathrm{H}_{14} \mathrm{O}_{2} \mathrm{Na} 213.09$; Found 213.51 .

HRMS (ESI) m/z: [M+Na] $]^{+}$Calcd. for $\mathrm{C}_{12} \mathrm{H}_{14} \mathrm{O}_{2} \mathrm{Na} 213.0891$; Found 213.0893.

$[\alpha]^{24} \mathrm{D}=-13.3\left(\mathrm{c}=0.0105, \mathrm{CH}_{2} \mathrm{Cl}_{2}\right)$

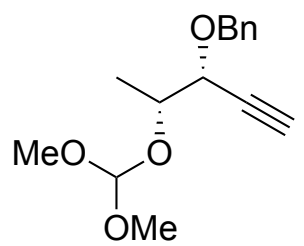

$(-)-3$

(2R,3R)-2-(dimethoxymethoxy)-3-(benzyloxy)pent-4-yne (-)-3

The title compound was prepared following the same procedure used for compound (-)-1. A solution of trimethyl orthoformate $(34.6 \mathrm{~mL}, 315 \mathrm{mmol})$ in anhydrous $\mathrm{CH}_{2} \mathrm{Cl}_{2}(9.34 \mathrm{~mL})$ was treated with solid magnesium chloride $(0.188 \mathrm{~g}, 1.97 \mathrm{mmol})$ that had been dried in vacuo overnight at $130{ }^{\circ} \mathrm{C}$. After being stirred for $20 \mathrm{~min}$, a solution of (-)-21 (1.5 g, $\left.7.88 \mathrm{mmol}\right)$ in anhydrous $\mathrm{CH}_{2} \mathrm{Cl}_{2}(14 \mathrm{~mL})$ was added into the mixture. Purification by flash column chromatography on neutralized silica gel (20\% ethyl acetate in hexanes) afforded compound (-)$3(1.69 \mathrm{~g}, 81 \%)$ as a colorless oil.

${ }^{1} \mathrm{H}$ NMR $\left(500 \mathrm{MHz}, \mathrm{C}_{6} \mathrm{D}_{6}\right) \delta$ 7.30-7.06 (m, 5H), $5.16(\mathrm{~s}, 1 \mathrm{H}), 4.79(\mathrm{~d}, J=11.7 \mathrm{~Hz}, 1 \mathrm{H}), 4.38(\mathrm{~d}$, $J=11.7 \mathrm{~Hz}, 1 \mathrm{H}), 4.27(\mathrm{dd}, J=6.0,2.1 \mathrm{~Hz}, 1 \mathrm{H}), 4.10(\mathrm{p}, J=6.0 \mathrm{~Hz}, 1 \mathrm{H}), 3.17(\mathrm{~s}, 3 \mathrm{H}), 3.13(\mathrm{~s}$, $3 \mathrm{H}), 2.04(\mathrm{~d}, J=2.0 \mathrm{~Hz}, 1 \mathrm{H}), 1.43(\mathrm{~d}, J=6.4 \mathrm{~Hz}, 3 \mathrm{H})$.

${ }^{13} \mathrm{C}$ NMR $\left(125 \mathrm{MHz}, \mathrm{C}_{6} \mathrm{D}_{6}\right) \delta 137.9,128.2,127.9,127.8,127.6,113.9,80.4,75.2,72.9,71.6$, $70.9,50.8,50.4,16.6$. 
LRMS (ESI) m/z: [M+Na] $]^{+}$Calcd. for $\mathrm{C}_{15} \mathrm{H}_{20} \mathrm{O}_{4} \mathrm{Na} 287.13$; Found 287.49 .

HRMS (ESI) m/z: [M+Na] $]^{+}$Calcd. for $\mathrm{C}_{15} \mathrm{H}_{20} \mathrm{O}_{4} \mathrm{Na}$ 287.1259; Found 287.1263.

$\alpha]^{24} \mathrm{D}=-1.98\left(\mathrm{c}=0.0562, \mathrm{CH}_{2} \mathrm{Cl}_{2}\right)$

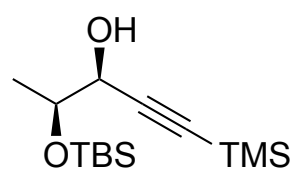

$(+)-20$

\section{(2S,3S)-2-((tert-butyldimethylsilyl)oxy)-5-(trimethylsilyl)pent-4-yn-3-ol (+)-20}

The title compound was prepared following the same procedure used for compound (-)-15 ${ }^{3}$. A solution of trimethylsilyl acetylene $(4.41 \mathrm{~mL}, 31.9 \mathrm{mmol})$ in anhydrous toluene $(31.1 \mathrm{~mL})$ was treated dropwise with diethylzinc $(1.5 \mathrm{M}$ in toluene, $21.2 \mathrm{~mL}, 31.9 \mathrm{mmol})$ and refluxed for 2.5 hours, resulting in the formation of a thick, grey precipitate. The solution was then cooled to 23 ${ }^{\circ} \mathrm{C}$ and diluted with anhydrous diethyl ether $(92 \mathrm{~mL})$. The mixture was treated with $(S)$-BINOL $(0.912 \mathrm{~g}, 3.19 \mathrm{mmol})$ and $\mathrm{Ti}\left(\mathrm{O}^{i} \mathrm{Pr}\right)_{4}(2.36 \mathrm{~mL}, 7.96 \mathrm{mmol})$ and stirred vigorously for 1.5 hours at $23{ }^{\circ} \mathrm{C}$ before a solution of compound (-)-14 $(1.50 \mathrm{~g}, 7.96 \mathrm{mmol})$ in anhydrous diethyl ether $(21$ $\mathrm{mL}$ ) was added to the mixture. After stirring overnight at $23{ }^{\circ} \mathrm{C}$, the reaction was cooled to $0{ }^{\circ} \mathrm{C}$ and then quenched with $1 \mathrm{M}$ aq. tartaric acid $(150 \mathrm{~mL})$. The resulting mixture was stirred at $23{ }^{\circ} \mathrm{C}$ for $30 \mathrm{~min}$ and then diluted with $\mathrm{H}_{2} \mathrm{O}(200 \mathrm{~mL})$. The layers were separated, and the aqueous layer was extracted with $\mathrm{Et}_{2} \mathrm{O}(4 \mathrm{x})$. The pooled organic layers were washed with $\mathrm{H}_{2} \mathrm{O}(1 \mathrm{x})$, sat. aq. sodium bicarbonate (1x), brine (1x), dried over $\mathrm{Na}_{2} \mathrm{SO}_{4}$, filtered, and concentrated in vacuo at 25 ${ }^{\circ} \mathrm{C}$. Purification by flash column chromatography on silica gel (60\% dichloromethane in hexanes) afforded compound $(+)-20(1.69,74 \%, 5: 1)$ as a clear oil. The spectroscopic data is in good agreement with previously reported values. ${ }^{3}$

Major Diastereomer:

${ }^{1} \mathrm{H}$ NMR $\left(500 \mathrm{MHz}, \mathrm{CDCl}_{3}\right) \delta 4.06(\mathrm{dd}, J=6.1,5.1 \mathrm{~Hz}, 1 \mathrm{H}), 3.90-3.85(\mathrm{~m}, 1 \mathrm{H}), 2.58(\mathrm{~d}, J=6.2$ $\mathrm{Hz}, 1 \mathrm{H}), 1.22$ (d, $J=6.2 \mathrm{~Hz}, 3 \mathrm{H}), 0.91$ (s, 9H), 0.17 (s, 9H), 0.13 (s, 3H), 0.11 (s, 3H).

${ }^{13} \mathrm{C}$ NMR $\left(125 \mathrm{MHz}, \mathrm{CDCl}_{3}\right) \delta 104.8,89.8,71.9,67.8,25.8,20.2,18.2,-0.2,-4.4,-4.7$.

LRMS (ESI) m/z: [M+Na] $]^{+}$Calcd. for $\mathrm{C}_{14} \mathrm{H}_{30} \mathrm{O}_{2} \mathrm{Si}_{2} \mathrm{Na}$ 309.55; Found 309.75 .<smiles>C#CC(O)C(C)O</smiles>

$(+)-21$ 
i. The title compound was prepared over two steps following a combination of the procedures used for compounds (-)-16 and (-)-17. A suspension of sodium hydride (60\% in mineral oil, $0.866 \mathrm{~g}$, $21.7 \mathrm{mmol})$ in DMF $(28.4 \mathrm{~mL})$ was cooled to $0{ }^{\circ} \mathrm{C}$ and treated with a solution of $(+)-20(1.40 \mathrm{~g}$, $4.92 \mathrm{mmol})$ in DMF $(31.7 \mathrm{~mL})$. After stirring at $0{ }^{\circ} \mathrm{C}$ for $10 \mathrm{~min}$, benzyl bromide $(2.57 \mathrm{~mL}, 21.7$ mmol) was added dropwise and the resulting mixture was warmed from $0{ }^{\circ} \mathrm{C}$ to $23{ }^{\circ} \mathrm{C}$ overnight with stirring. The reaction was then quenched with sat. aq. $\mathrm{NH}_{4} \mathrm{Cl}(30 \mathrm{~mL})$ at $23{ }^{\circ} \mathrm{C}$ and the resulting mixture was diluted with $\mathrm{H}_{2} \mathrm{O}(400 \mathrm{~mL})$ and extracted with $\mathrm{Et}_{2} \mathrm{O}(4 \mathrm{x})$. The pooled organic layers were washed with $\mathrm{H}_{2} \mathrm{O}(2 \mathrm{x}), 1 \mathrm{M} \mathrm{LiCl}(2 \mathrm{x})$, brine $(1 \mathrm{x})$, dried over $\mathrm{Na}_{2} \mathrm{SO}_{4}$, filtered, and concentrated in vacuo at $25^{\circ} \mathrm{C}$.

ii. The crude residue was dissolved in THF $(34.3 \mathrm{~mL})$, cooled to $0{ }^{\circ} \mathrm{C}$, and treated with tetrabutylammonium fluoride $(1.0 \mathrm{M}$ in THF, $4.65 \mathrm{~mL}, 4.65 \mathrm{mmol})$. The resulting reaction was warmed to $23{ }^{\circ} \mathrm{C}$ and stirred for 2 hours. Upon complete consumption of starting material, the reaction was concentrated in vacuo at $25{ }^{\circ} \mathrm{C}$. Purification by flash column chromatography on silica gel (30\% dichloromethane in hexanes) afforded compound $(+)-21(0.553 \mathrm{~g}, 60 \%$ yield over two steps) as a slightly yellow oil.

${ }^{1} \mathrm{H}$ NMR (500 MHz, $\left.\mathrm{CDCl}_{3}\right) \delta$ 7.37-7.26 (m, 5H), $4.87(\mathrm{~d}, \mathrm{~J}=11.4 \mathrm{~Hz}, 1 \mathrm{H}), 4.53(\mathrm{~d}, \mathrm{~J}=11.5 \mathrm{~Hz}$, $1 \mathrm{H}), 3.92-3.86(\mathrm{~m}, 2 \mathrm{H}), 2.59(\mathrm{~s}, 1 \mathrm{H}), 2.52(\mathrm{~d}, \mathrm{~J}=1.7 \mathrm{~Hz}, 1 \mathrm{H}), 1.29(\mathrm{~d}, \mathrm{~J}=5.9 \mathrm{~Hz}, 3 \mathrm{H})$.

${ }^{13} \mathrm{C} \mathrm{NMR}\left(125 \mathrm{MHz}, \mathrm{CDCl}_{3}\right) \delta 137.2,128.5,128.2,128.0,80.1,75.7,74.0,71.1,69.8,18.2$.

LRMS (ESI) m/z: [M+Na] $]^{+}$Calcd. for $\mathrm{C}_{12} \mathrm{H}_{14} \mathrm{O}_{2} \mathrm{Na} 213.09$; Found 213.46.

HRMS (ESI) m/z: [M+Na] $]^{+}$Calcd. for $\mathrm{C}_{12} \mathrm{H}_{14} \mathrm{O}_{2} \mathrm{Na} 213.0891$; Found 213.0892.

$[\alpha]^{24}{ }_{\mathrm{D}}=4.86\left(\mathrm{c}=0.0484, \mathrm{CH}_{2} \mathrm{Cl}_{2}\right)$

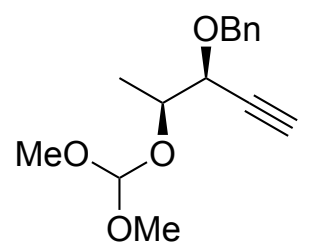

$(+)-3$

(2S,3S)-2-(dimethoxymethoxy)-3-(benzyloxy)pent-4-yne (+)-3

The title compound was prepared following the same procedure used for compound (-)-1. A solution of trimethyl orthoformate $(34.6 \mathrm{~mL}, 315 \mathrm{mmol})$ in anhydrous $\mathrm{CH}_{2} \mathrm{Cl}_{2}(9.34 \mathrm{~mL})$ was treated with solid magnesium chloride $(0.188 \mathrm{~g}, 1.97 \mathrm{mmol})$ that had been dried in vacuo overnight at $130{ }^{\circ} \mathrm{C}$. After being stirred for $20 \mathrm{~min}$, a solution of $(+)-21(1.5 \mathrm{~g}, 7.88 \mathrm{mmol})$ in anhydrous $\mathrm{CH}_{2} \mathrm{Cl}_{2}(14 \mathrm{~mL})$ was added into the mixture. Purification by flash column 
chromatography on neutralized silica gel ( $20 \%$ ethyl acetate in hexanes) afforded compound $(+)-$ $3(1.67 \mathrm{~g}, 80 \%)$ as a colorless oil.

${ }^{1} \mathrm{H}$ NMR $\left(500 \mathrm{MHz}, \mathrm{C}_{6} \mathrm{D}_{6}\right) \delta$ 7.30-7.06 (m, 5H), $5.17(\mathrm{~s}, 1 \mathrm{H}), 4.79(\mathrm{~d}, J=11.7 \mathrm{~Hz}, 1 \mathrm{H}), 4.40-$ $4.35(\mathrm{~m}, 1 \mathrm{H}), 4.27(\mathrm{dd}, J=6.0,2.1 \mathrm{~Hz}, 1 \mathrm{H}), 4.10(\mathrm{p}, J=6.0 \mathrm{~Hz}, 1 \mathrm{H}), 3.17(\mathrm{~s}, 3 \mathrm{H}), 3.13(\mathrm{~s}, 3 \mathrm{H})$, $2.04(\mathrm{~d}, J=2.0 \mathrm{~Hz}, 1 \mathrm{H}), 1.43(\mathrm{~d}, J=6.3 \mathrm{~Hz}, 3 \mathrm{H})$.

${ }^{13} \mathrm{C}$ NMR (125 MHz, $\left.\mathrm{C}_{6} \mathrm{D}_{6}\right) \delta 137.9,128.2,127.9,127.8,127.6,113.9,80.4,75.2,72.9,71.6$, $70.9,50.8,50.4,16.6$.

LRMS (ESI) m/z: [M+Na] $]^{+}$Calcd. for $\mathrm{C}_{15} \mathrm{H}_{20} \mathrm{O}_{4} \mathrm{Na} 287.13$; Found 287.57 .

HRMS (ESI) m/z: [M+Na] $]^{+}$Calcd. for $\mathrm{C}_{15} \mathrm{H}_{20} \mathrm{O}_{4} \mathrm{Na} 287.1259$; Found 287.1261.

$[\alpha]^{24} \mathrm{D}=12.5\left(\mathrm{c}=0.0157, \mathrm{CH}_{2} \mathrm{Cl}_{2}\right)$

\section{S2.3 General Procedure A for Gold-Catalyzed Cyclizations}

i. A suspension of the gold (I) complex $(0.168 \mathrm{~g}, 0.132 \mathrm{mmol})$ and activated $4 \AA$ molecular sieves $(0.675 \mathrm{~g})$ in anhydrous $\mathrm{CH}_{2} \mathrm{Cl}_{2}(76 \mathrm{~mL})$ was treated with a solution of the corresponding orthoester $(1.00 \mathrm{~g}, 3.78 \mathrm{mmol})$ and 2,6-di-tert-butylpyridine (DTBP) $(15 \mu \mathrm{L}, 0.0662 \mathrm{mmol}){ }^{5,6}$ The reaction was stirred for $30 \mathrm{~min}$ at $23{ }^{\circ} \mathrm{C}$ and then quenched with triethyl amine $(3 \mathrm{~mL})$. The resulting solution was stirred for $5 \mathrm{~min}$ and then filtered with ethyl acetate $(500 \mathrm{~mL})$ through a pad of neutralized silica gel. The filtrate was concentrated in vacuo at $20{ }^{\circ} \mathrm{C}$ and then dried on high vacuum for 30 minutes to remove any remaining triethyl amine.

ii. The oil residue was then dissolved in THF $(76 \mathrm{~mL})$ and treated with $p$-toluenesulfonic acid monohydrate $\left(p-\mathrm{TSA} \cdot \mathrm{H}_{2} \mathrm{O}\right)(720 \mathrm{mg}, 3.78 \mathrm{mmol})$. The reaction was stirred for 2 hours at $23{ }^{\circ} \mathrm{C}$ and then quenched with triethyl amine $(3 \mathrm{~mL})$. The resulting solution was stirred for 5 min and then filtered with ethyl acetate $(500 \mathrm{~mL})$ through a pad of neutralized silica gel. The filtrate was concentrated in vacuo at $20^{\circ} \mathrm{C}$. Purification by flash column chromatography on neutralized silica gel (20\% diethyl ether in hexanes) afforded the corresponding enone.

S2.4 Synthesis of Enones 4-6<smiles>C[C@H]1OC=CC(=O)[C@@H]1O[Hg]Br</smiles>

$(+)-4$

(2R,3R)-3-(benzyloxy)-2-methyl-2,3-dihydro-4H-pyran-4-one (+)-4

The title compound was prepared following General Procedure A using orthoester (-)-1 (2.00 g, $7.56 \mathrm{mmol})$ with gold (I) complex $(0.336 \mathrm{~g}, 0.265 \mathrm{mmol}), 4 \mathrm{~A}$ molecular sieves $(1.35 \mathrm{~g})$, and DTBP $(30 \mu \mathrm{L}, 0.132 \mathrm{mmol})$ in anhydrous $\mathrm{CH}_{2} \mathrm{Cl}_{2}(152 \mathrm{~mL})$. In the second step, the crude residue was dissolved in THF $(152 \mathrm{~mL})$ and treated with $p-\mathrm{TSA} \cdot \mathrm{H}_{2} \mathrm{O}(1.44 \mathrm{~g}, 7.56 \mathrm{mmol})$. Purification by 
flash column chromatography (20\% ethyl acetate in hexanes) afforded $(+)-4(1.43 \mathrm{~g}, 87 \%)$ as an oil.

${ }^{1} \mathrm{H}$ NMR $\left(500 \mathrm{MHz}, \mathrm{C}_{6} \mathrm{D}_{6}\right) \delta$ 7.31-7.04 (m, 5H), $6.46(\mathrm{~d}, J=5.9 \mathrm{~Hz}, 1 \mathrm{H}), 5.11(\mathrm{~d}, J=5.9 \mathrm{~Hz}$, $1 \mathrm{H}), 5.07(\mathrm{~d}, J=11.5 \mathrm{~Hz}, 1 \mathrm{H}), 4.51(\mathrm{~d}, J=11.5 \mathrm{~Hz}, 1 \mathrm{H}), 4.07(\mathrm{dq}, J=9.9,6.4 \mathrm{~Hz}, 1 \mathrm{H}), 3.36(\mathrm{~d}$, $J=9.8 \mathrm{~Hz}, 1 \mathrm{H}), 1.05(\mathrm{~d}, J=6.5 \mathrm{~Hz}, 3 \mathrm{H})$.

${ }^{13} \mathrm{C}$ NMR $\left(125 \mathrm{MHz}, \mathrm{C}_{6} \mathrm{D}_{6}\right) \delta 191.8,160.9,138.0,128.3,128.2,127.9,127.8,127.6,104.9,78.6$, $78.3,73.6,16.7$.

LRMS (ESI) m/z: [M+Na] ${ }^{+}$Calcd. for $\mathrm{C}_{13} \mathrm{H}_{14} \mathrm{O}_{3} \mathrm{Na} 241.08$; Found 241.49.

HRMS (ESI) m/z: [M+Na] $]^{+}$Calcd. for $\mathrm{C}_{13} \mathrm{H}_{14} \mathrm{O}_{3} \mathrm{Na} 241.0841$; Found 241.0842.

$[\alpha]^{24}{ }_{\mathrm{D}}=14.2\left(\mathrm{c}=0.0121, \mathrm{CH}_{2} \mathrm{Cl}_{2}\right)$

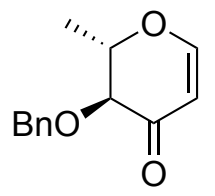

$(-)-4$

(2S,3S)-3-(benzyloxy)-2-methyl-2,3-dihydro-4H-pyran-4-one (-)-4

The title compound was prepared following General Procedure A using orthoester $(+)-1$ (2.00 g, $7.56 \mathrm{mmol})$ with gold (I) complex $(0.336 \mathrm{~g}, 0.265 \mathrm{mmol}), 4 \mathrm{~A}$ molecular sieves $(1.35 \mathrm{~g})$, and DTBP $(30 \mu \mathrm{L}, 0.132 \mathrm{mmol})$ in anhydrous $\mathrm{CH}_{2} \mathrm{Cl}_{2}(152 \mathrm{~mL})$. In the second step, the crude residue was dissolved in THF $(152 \mathrm{~mL})$ and treated with $p-\mathrm{TSA} \cdot \mathrm{H}_{2} \mathrm{O}(1.44 \mathrm{~g}, 7.56 \mathrm{mmol})$. Purification by flash column chromatography (20\% ethyl acetate in hexanes) afforded (-)-4 (1.41 g, 86\%) as an oil. The spectroscopic data was in good agreement with previously reported values. ${ }^{7}$

${ }^{1} \mathrm{H}$ NMR $\left(500 \mathrm{MHz}, \mathrm{C}_{6} \mathrm{D}_{6}\right) \delta$ 7.31-7.04 (m, 5H), $6.46(\mathrm{~d}, J=5.9 \mathrm{~Hz}, 1 \mathrm{H}), 5.11(\mathrm{~d}, J=5.9 \mathrm{~Hz}, 1 \mathrm{H})$, $5.07(\mathrm{~d}, J=11.5 \mathrm{~Hz}, 1 \mathrm{H}), 4.51(\mathrm{~d}, J=11.5 \mathrm{~Hz}, 1 \mathrm{H}), 4.07(\mathrm{dq}, J=9.9,6.4 \mathrm{~Hz}, 1 \mathrm{H}), 3.36(\mathrm{~d}, J=$ $9.8 \mathrm{~Hz}, 1 \mathrm{H}), 1.05(\mathrm{~d}, J=6.5 \mathrm{~Hz}, 3 \mathrm{H})$.

${ }^{13} \mathrm{C}$ NMR $\left(125 \mathrm{MHz}, \mathrm{C}_{6} \mathrm{D}_{6}\right) \delta 191.8,160.9,138.0,128.3,128.2,127.9,127.8,127.6,104.9,78.6$, $78.3,73.6,16.7$.

LRMS (ESI) m/z: [M+Na] $]^{+}$Calcd. for $\mathrm{C}_{13} \mathrm{H}_{14} \mathrm{O}_{3} \mathrm{Na} 241.08$; Found 242.01. 


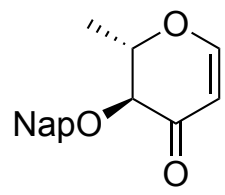

$(-)-5$

(2S,3S)-3-(naphthyloxy)-2-methyl-2,3-dihydro-4H-pyran-4-one (-)-5

The title compound was prepared following General Procedure A using orthoester $(+)-2(2.00 \mathrm{~g}$, $6.36 \mathrm{mmol})$ with gold (I) complex $(0.283 \mathrm{~g}, 0.223 \mathrm{mmol}), 4 \mathrm{~A}$ molecular sieves $(1.50 \mathrm{~g})$, and DTBP $(25 \mu \mathrm{L}, 0.111 \mathrm{mmol})$ in anhydrous $\mathrm{CH}_{2} \mathrm{Cl}_{2}(160 \mathrm{~mL})$. In the second step, the crude residue was dissolved in THF $(160 \mathrm{~mL})$ and treated with $p-\mathrm{TSA} \cdot \mathrm{H}_{2} \mathrm{O}(1.21 \mathrm{~g}, 6.36 \mathrm{mmol})$. Purification by flash column chromatography (20\% ethyl acetate in hexanes) afforded (-)-5 (1.54 g, 90\%) as a white solid. The spectroscopic data was in good agreement with previously reported values. ${ }^{8}$

${ }^{1} \mathrm{H}$ NMR $\left(500 \mathrm{MHz}, \mathrm{CDCl}_{3}\right) \delta$ 7.86-7.44 (m, 7H), $7.27(\mathrm{~d}, J=5.9 \mathrm{~Hz}, 1 \mathrm{H}), 5.39(\mathrm{~d}, J=5.9 \mathrm{~Hz}$, $1 \mathrm{H}), 5.19(\mathrm{~d}, J=11.7 \mathrm{~Hz}, 1 \mathrm{H}), 4.84(\mathrm{~d}, J=11.7 \mathrm{~Hz}, 1 \mathrm{H}), 4.50(\mathrm{dq}, J=9.8,6.5 \mathrm{~Hz}, 1 \mathrm{H}), 3.76(\mathrm{~d}$, $J=9.8 \mathrm{~Hz}, 1 \mathrm{H}), 1.43(\mathrm{~d}, J=6.5 \mathrm{~Hz}, 3 \mathrm{H})$.

${ }^{13} \mathrm{C} \mathrm{NMR}\left(125 \mathrm{MHz}, \mathrm{CDCl}_{3}\right) \delta 193.1,162.2,134.8,133.2,133.2,128.3,127.9,127.7,127.5$, $126.3,126.2,126.1,105.1,78.7,78.4,73.9,17.2$.

LRMS (ESI) m/z: [M+Na $]^{+}$Calcd. for $\mathrm{C}_{17} \mathrm{H}_{16} \mathrm{O}_{3} \mathrm{Na}$ 291.30; Found 291.64.<smiles>C[C@H]1OC=CC(=O)[C@@H]1OCc1ccccc1</smiles>

$(+)-6$

\section{(2R,3S)-3-(benzyloxy)-2-methyl-2,3-dihydro-4H-pyran-4-one (+)-6}

The title compound was prepared following General Procedure A using orthoester (-)-3 (2.00 g, $7.56 \mathrm{mmol})$ with gold (I) complex $(0.336 \mathrm{~g}, 0.265 \mathrm{mmol}), 4 \mathrm{~A}$ molecular sieves $(1.35 \mathrm{~g})$, and DTBP $(30 \mu \mathrm{L}, 0.132 \mathrm{mmol})$ in anhydrous $\mathrm{CH}_{2} \mathrm{Cl}_{2}(152 \mathrm{~mL})$. In the second step, the crude residue was dissolved in THF $(152 \mathrm{~mL})$ and treated with $p-\mathrm{TSA} \cdot \mathrm{H}_{2} \mathrm{O}(1.44 \mathrm{~g}, 7.56 \mathrm{mmol})$. Purification by flash column chromatography (20\% ethyl acetate in hexanes) afforded $(+)-6(1.17 \mathrm{~g}, 71 \%)$ as an amorphous solid.

${ }^{1} \mathrm{H}$ NMR $\left(500 \mathrm{MHz}, \mathrm{C}_{6} \mathrm{D}_{6}\right) \delta$ 7.35-7.10 (m, 5H), $6.69(\mathrm{~d}, J=6.0 \mathrm{~Hz}, 1 \mathrm{H}), 5.29(\mathrm{dd}, J=6.0,1.4$ $\mathrm{Hz}, 1 \mathrm{H}), 4.83(\mathrm{~d}, J=12.0 \mathrm{~Hz}, 1 \mathrm{H}), 4.52$ (d, $J=12.0 \mathrm{~Hz}, 1 \mathrm{H}), 3.80(\mathrm{dq}, J=11,3.5 \mathrm{~Hz}, 1 \mathrm{H}), 3.29$ $3.22(\mathrm{~m}, 1 \mathrm{H}), 1.20(\mathrm{~d}, J=6.7 \mathrm{~Hz}, 3 \mathrm{H})$.

${ }^{13} \mathrm{C}$ NMR $\left(125 \mathrm{MHz}, \mathrm{C}_{6} \mathrm{D}_{6}\right) \delta 189.4,162.1,137.8,128.4,128.3,127.7,104.5,77.9,76.5,71.7$, 14.8 . 
LRMS (ESI) m/z: [M+Na] $]^{+}$Calcd. for $\mathrm{C}_{13} \mathrm{H}_{14} \mathrm{O}_{3} \mathrm{Na} 241.08$; Found 241.56 .

HRMS (ESI) m/z: [M+Na] $]^{+}$Calcd. for $\mathrm{C}_{13} \mathrm{H}_{14} \mathrm{O}_{3} \mathrm{Na} 241.0841$; Found 241.0843 .

$[\alpha]^{24} \mathrm{D}=3.05\left(\mathrm{c}=0.220, \mathrm{CH}_{2} \mathrm{Cl}_{2}\right)$<smiles>C[C@H]1OC=CC(=O)[C@@H]1OCc1ccccc1</smiles>

(-)-6

(2S,3R)-3-(benzyloxy)-2-methyl-2,3-dihydro-4H-pyran-4-one (-)-6

The title compound was prepared following General Procedure A using orthoester $(+)-3(2.00 \mathrm{~g}$, $7.56 \mathrm{mmol})$ with gold (I) complex $(0.336 \mathrm{~g}, 0.265 \mathrm{mmol}), 4 \mathrm{~A}$ molecular sieves $(1.35 \mathrm{~g})$, and DTBP $(30 \mu \mathrm{L}, 0.132 \mathrm{mmol})$ in anhydrous $\mathrm{CH}_{2} \mathrm{Cl}_{2}(152 \mathrm{~mL})$. In the second step, the crude residue was dissolved in THF $(152 \mathrm{~mL})$ and treated with $p-\mathrm{TSA} \cdot \mathrm{H}_{2} \mathrm{O}(1.44 \mathrm{~g}, 7.56 \mathrm{mmol})$. Purification by flash column chromatography (20\% ethyl acetate in hexanes) afforded (-)-6 (1.22 g, 74\%) as an amorphous solid. The spectroscopic data was in good agreement with previously reported values. ${ }^{7}$

${ }^{1} \mathrm{H}$ NMR $\left(500 \mathrm{MHz}, \mathrm{C}_{6} \mathrm{D}_{6}\right) \delta$ 7.35-7.04 (m, 5H), $6.69(\mathrm{~d}, J=6.0 \mathrm{~Hz}, 1 \mathrm{H}), 5.29(\mathrm{dd}, J=6.0,1.4$ $\mathrm{Hz}, 1 \mathrm{H}), 4.83(\mathrm{~d}, J=12.0 \mathrm{~Hz}, 1 \mathrm{H}), 4.52(\mathrm{~d}, J=12.0 \mathrm{~Hz}, 1 \mathrm{H}), 3.80$ (dq, $J=11,3.5 \mathrm{~Hz}, 1 \mathrm{H}), 3.29-$ $3.22(\mathrm{~m}, 1 \mathrm{H}), 1.20(\mathrm{~d}, J=6.7 \mathrm{~Hz}, 3 \mathrm{H})$.

${ }^{13} \mathrm{C}$ NMR $\left(125 \mathrm{MHz}, \mathrm{C}_{6} \mathrm{D}_{6}\right) \delta 189.4,162.1,137.8,128.4,128.3,127.7,104.5,77.9,76.5,71.7$, 14.8 .

LRMS (ESI) m/z: [M+Na] $]^{+}$Calcd. for $\mathrm{C}_{13} \mathrm{H}_{14} \mathrm{O}_{3} \mathrm{Na} 241.08$; Found 241.93 .

\section{S3. Derivatization of Enones into Deoxy Sugars}

S3.1 Synthesis of L-digitoxose (-)-7<smiles>C[C@@H]1OC=CC(=O)[C@@H]1O[N+]([O-])([O-])[O-]</smiles>

$(-)-5$

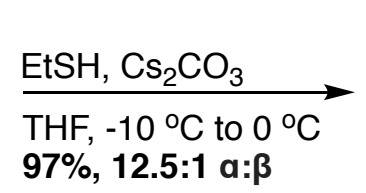

$97 \%, 12.5: 1$ a: $\beta$<smiles>CC[C@H]1CC(=O)[C@H](O[N+](=O)[O-])[C@@H](C)O1</smiles>

$(-)-22$

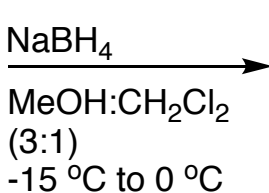

$80 \%$

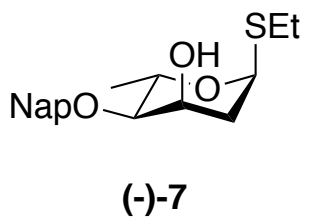

L-digitoxose 


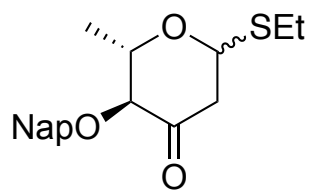

$(-)-22$

4-O-naphthyl-2,6-dideoxy-1-ethanethiol-L-erythro-hexopyranosid-3-ulose (-)-22

A solution of enone (-)-5 $(1.00 \mathrm{~g}, 3.73 \mathrm{mmol})$ in anhydrous THF $(30 \mathrm{~mL})$ was cooled to $-10{ }^{\circ} \mathrm{C}$ using a brine bath and then treated with cesium carbonate $(1.21 \mathrm{~g}, 3.73 \mathrm{mmol})$. After stirring for 5 minutes at $-10{ }^{\circ} \mathrm{C}$, ethanethiol $(1.10 \mathrm{~mL}, 14.9 \mathrm{mmol})$ was added dropwise to the reaction and was stirred for 30 minutes at that same temperature. After 30 minutes, the flask was moved to a 0 ${ }^{\circ} \mathrm{C}$ bath and stirred for another 30 minutes. When TLC indicated complete consumption of starting material, the reaction mixture was diluted with $\mathrm{H}_{2} \mathrm{O}$ and extracted with $\mathrm{CH}_{2} \mathrm{Cl}_{2}(3 \mathrm{x})$. The pooled organic layers were washed with brine $(1 \mathrm{x})$, dried over $\mathrm{Na}_{2} \mathrm{SO}_{4}$, filtered, and concentrated in vacuo at $25^{\circ} \mathrm{C}$. Purification by flash column chromatography on silica gel (10 to $20 \%$ ethyl acetate in hexanes) afforded (-)-22 (1.20 g, 97\%,) as a mixture of anomers (12.5 $\alpha: \beta)$ that were not separated. The spectroscopic data was in good agreement with previously reported values. ${ }^{8}$

Major Anomer:

${ }^{1} \mathrm{H}$ NMR $\left(500 \mathrm{MHz}, \mathrm{CDCl}_{3}\right) \delta$ 7.85-7.44 (m, 7H), $5.56(\mathrm{~d}, J=7.2 \mathrm{~Hz}, 1 \mathrm{H}), 5.11(\mathrm{~d}, J=11.6 \mathrm{~Hz}$, $1 \mathrm{H}), 4.68(\mathrm{~d}, J=11.7 \mathrm{~Hz}, 1 \mathrm{H}), 4.44(\mathrm{dq}, J=9.4,6.1 \mathrm{~Hz}, 1 \mathrm{H}), 3.65(\mathrm{dd}, J=9.4,0.9 \mathrm{~Hz}, 1 \mathrm{H}), 3.06$ (ddd, $J=14.4,7.3,1.1 \mathrm{~Hz}, 1 \mathrm{H}), 2.65-2.56(\mathrm{~m}, 2 \mathrm{H}), 2.55-2.46(\mathrm{~m}, 1 \mathrm{H}), 1.38(\mathrm{~d}, J=6.1 \mathrm{~Hz}, 3 \mathrm{H})$, $1.26(\mathrm{t}, J=7.4 \mathrm{~Hz}, 3 \mathrm{H})$.

${ }^{13} \mathrm{C}$ NMR $\left(125 \mathrm{MHz}, \mathrm{CDCl}_{3}\right) \delta 203.2,134.9,133.2,133.2,128.3,127.9,127.7,127.2,126.2$, $126.2,126.0,84.4,80.2,73.3,69.5,46.5,24.6,18.8,14.6$.

LRMS (ESI) m/z: [M+Na] $]^{+}$Calcd. for $\mathrm{C}_{19} \mathrm{H}_{22} \mathrm{O}_{3} \mathrm{SNa}$ 353.43; Found 353.63 .

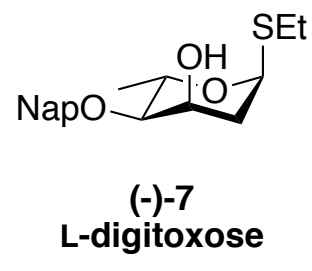

4-O-naphtyl-1-ethanethiol- $\alpha$-L-digitoxose (-)-7

A solution of ketone (-)-22 (1.00 g, $3.03 \mathrm{mmol})$ in $\mathrm{MeOH}(26.8 \mathrm{~mL})$ and $\mathrm{CH}_{2} \mathrm{Cl}_{2}(8.92 \mathrm{~mL})$ was cooled to $-15{ }^{\circ} \mathrm{C}$ and $\mathrm{NaBH}_{4}(0.343 \mathrm{~g}, 9.09 \mathrm{mmol})$ was added in 3 portions. The solution was allowed to warm up gradually to $0{ }^{\circ} \mathrm{C}$ and stirred for 1 hour. Upon complete consumption of starting material, the reaction was quenched with sat. aq. $\mathrm{NH}_{4} \mathrm{Cl}(5 \mathrm{~mL})$ and acetone $(5 \mathrm{~mL})$ at 0 ${ }^{\circ} \mathrm{C}$ and then concentrated in vacuo. To the residue, $\mathrm{H}_{2} \mathrm{O}(20 \mathrm{~mL})$ and $\mathrm{CH}_{2} \mathrm{Cl}_{2}(20 \mathrm{~mL})$ were added 
and the aqueous layer extracted with $\mathrm{CH}_{2} \mathrm{Cl}_{2}(3 \mathrm{x})$. The pooled organic layers were washed with brine (1x), dried over $\mathrm{Na}_{2} \mathrm{SO}_{4}$, filtered, and concentrated in vacuo. Purification by flash column chromatography on silica gel (20\% ethyl acetate in hexanes) afforded (-)-7 (0.802 g, 80\%) as a white solid. The spectroscopic data was in good agreement with previously reported values. ${ }^{8}$

${ }^{1} \mathrm{H}$ NMR $\left(500 \mathrm{MHz}, \mathrm{CDCl}_{3}\right) \delta$ 7.87-7.44 (m, 7H), $5.20(\mathrm{dd}, J=5.3,2.7 \mathrm{~Hz}, 1 \mathrm{H}), 4.82(\mathrm{~d}, J=11.8$ $\mathrm{Hz}, 1 \mathrm{H}), 4.71(\mathrm{~d}, J=11.8 \mathrm{~Hz}, 1 \mathrm{H}), 4.38(\mathrm{dq}, J=9.2,6.3 \mathrm{~Hz}, 1 \mathrm{H}), 4.22(\mathrm{p}, J=3.2 \mathrm{~Hz}, 1 \mathrm{H}), 3.19$ $(\mathrm{dd}, J=9.2,3.2 \mathrm{~Hz}, 1 \mathrm{H}), 2.66-2.63(\mathrm{~m}, 1 \mathrm{H}), 2.63-2.52(\mathrm{~m}, 2 \mathrm{H}), 2.21-2.16(\mathrm{~m}, 2 \mathrm{H}), 1.30-1.26$ $(\mathrm{m}, 6 \mathrm{H})$.

${ }^{13} \mathrm{C}$ NMR $\left(125 \mathrm{MHz}, \mathrm{CDCl}_{3}\right) \delta 135.2,133.2,133.1,128.4,127.9,127.7,126.7,126.3,126.1$, $125.7,80.1,78.7,71.2,63.8,62.5,36.1,26.3,17.9,14.9$.

LRMS (ESI) m/z: [M+Na] ${ }^{+}$Calcd. for $\mathrm{C}_{19} \mathrm{H}_{24} \mathrm{O}_{3} \mathrm{SNa} 355.13$; Found 355.71 .

S3.2 Preparation of L-olivose (-)-8
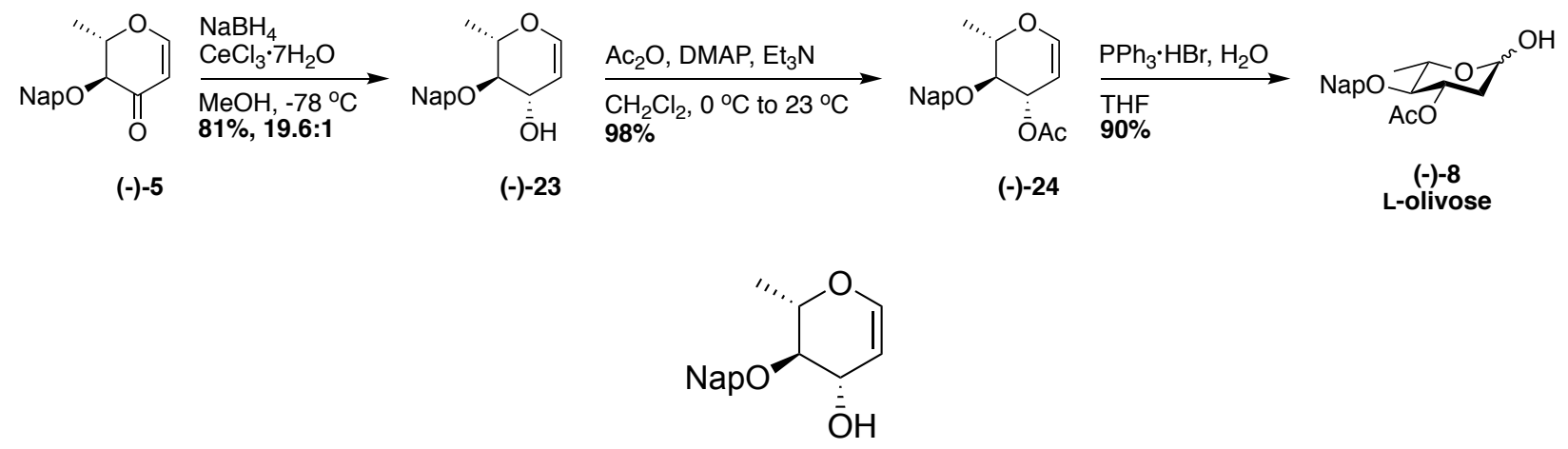

$(-)-23$

\section{4-O-naphthyl-L-rhamnal (-)-23}

The title compound was prepared according to a procedure adapted from Venukumar. ${ }^{9}$ Enone (-)$5(1.00 \mathrm{~g}, 3.73 \mathrm{mmol})$ and $\mathrm{CeCl}_{3} \cdot 7 \mathrm{H}_{2} \mathrm{O}(2.08 \mathrm{~g}, 5.59 \mathrm{mmol})$ were dissolved in $\mathrm{MeOH}(16.3 \mathrm{~mL})$ and cooled to $-78{ }^{\circ} \mathrm{C}$ using a dry ice/acetone bath. In a separate round bottom flask, $\mathrm{NaBH}_{4}(0.211$ g, $5.59 \mathrm{mmol})$ was dissolved in $\mathrm{MeOH}(5.7 \mathrm{~mL})$ and cooled to $-10{ }^{\circ} \mathrm{C}$ using a brine bath. After cooling for 5 minutes, the $\mathrm{NaBH}_{4} / \mathrm{MeOH}$ solution was added dropwise via syringe to the flask containing the enone at $-78{ }^{\circ} \mathrm{C}$. After stirring for 2 hours, upon which TLC indicated complete consumption of starting material, the reaction was quenched with sat. aq. $\mathrm{NH}_{4} \mathrm{Cl}(25 \mathrm{~mL})$ at -78 ${ }^{\circ} \mathrm{C}$ and the flask was subsequently removed from the bath and warmed to $23{ }^{\circ} \mathrm{C}$. The reaction was then diluted with $\mathrm{H}_{2} \mathrm{O}$ and extracted with EtOAc $(3 \mathrm{x})$. The pooled organic layers were washed with $\mathrm{H}_{2} \mathrm{O}(1 \mathrm{x})$, brine (1x), dried over $\mathrm{Na}_{2} \mathrm{SO}_{4}$, filtered, and concentrated in vacuo. Purification by flash column chromatography on silica gel (20 to 30\% ethyl acetate in hexanes) afforded (-)-23 $(0.812 \mathrm{~g}, 81 \%)$ as a separable mixture of diastereomers (19.6:1).

Major Diastereoemer: 
${ }^{1} \mathrm{H}$ NMR (500 MHz, $\left.\mathrm{CDCl}_{3}\right) \delta$ 7.86-7.45 (m, 7H), $6.33(\mathrm{dd}, J=6.0,1.5 \mathrm{~Hz}, 1 \mathrm{H}), 4.99(\mathrm{q}, J=11.7$ $\mathrm{Hz}, 2 \mathrm{H}), 4.71(\mathrm{dd}, J=6.0,2.4 \mathrm{~Hz}, 1 \mathrm{H}), 4.44-4.34(\mathrm{~m}, 1 \mathrm{H}), 3.94(\mathrm{dq}, J=9.6,6.4 \mathrm{~Hz}, 1 \mathrm{H}), 3.34$ $(\mathrm{dd}, J=9.6,6.9 \mathrm{~Hz}, 1 \mathrm{H}), 1.67(\mathrm{~d}, J=5.9 \mathrm{~Hz}, 1 \mathrm{H}), 1.43(\mathrm{~d}, J=6.4 \mathrm{~Hz}, 3 \mathrm{H})$.

${ }^{13} \mathrm{C}$ NMR $\left(125 \mathrm{MHz}, \mathrm{CDCl}_{3}\right) \delta 144.7,135.7,133.3,133.1,128.4,127.9,127.7,126.8,126.2$, $126.0,125.9,103.1,82.4,74.3,74.1,70.1,17.7$.

LRMS (ESI) m/z: [M+Na] $]^{+}$Calcd. for $\mathrm{C}_{17} \mathrm{H}_{18} \mathrm{O}_{3} \mathrm{Na}$ 293.12; Found 293.55.

HRMS (ESI) m/z: [M+Na] $]^{+}$Calcd. for $\mathrm{C}_{17} \mathrm{H}_{18} \mathrm{O}_{3} \mathrm{Na}$ 293.1154; Found 293.1157.

$[\alpha]^{24} \mathrm{D}=-4.89\left(\mathrm{c}=0.0323, \mathrm{CH}_{2} \mathrm{Cl}_{2}\right)$

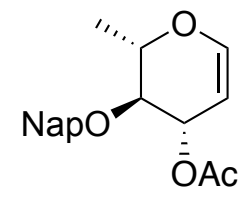

$(-)-24$

\section{3-O-acetyl-4-O-naphthyl-L-rhamnal (-)-24}

A solution of (-)-23 (0.360 g, $1.33 \mathrm{mmol}), \mathrm{Et}_{3} \mathrm{~N}(0.370 \mathrm{~mL}, 2.66 \mathrm{mmol})$, and 4Dimethylaminopyridine $(60.1 \mathrm{mg}, 0.492 \mathrm{mmol})$ in $\mathrm{CH}_{2} \mathrm{Cl}_{2}(32 \mathrm{~mL})$ was cooled to $0{ }^{\circ} \mathrm{C}$. After cooling for 5 minutes, $\mathrm{Ac}_{2} \mathrm{O}(0.380 \mathrm{~mL}, 3.99 \mathrm{mmol})$ was added slowly to the reaction. The flask was promptly removed from the $0{ }^{\circ} \mathrm{C}$ ice bath and stirred at $23{ }^{\circ} \mathrm{C}$. After stirring for 1 hour, upon which TLC indicated complete consumption of the starting material, the reaction was concentrated in vacuo. Purification by flash column chromatography on silica gel ( $20 \%$ ethyl acetate in hexanes) afforded (-)-24 (0.411 $\mathrm{g}, 98 \%)$ as an amorphous solid.

${ }^{1} \mathrm{H}$ NMR $\left(500 \mathrm{MHz}, \mathrm{CDCl}_{3}\right) \delta 7.86-7.42(\mathrm{~m}, 7 \mathrm{H}), 6.40(\mathrm{dd}, J=6.1,1.2 \mathrm{~Hz}, 1 \mathrm{H}), 5.43(\mathrm{ddd}, J=$ $6.0,2.8,1.1 \mathrm{~Hz}, 1 \mathrm{H}), 4.86(\mathrm{q}, J=11.9 \mathrm{~Hz}, 2 \mathrm{H}), 4.77-4.72(\mathrm{~m}, 1 \mathrm{H}), 4.08(\mathrm{dq}, J=13.1,6.5 \mathrm{~Hz}, 1 \mathrm{H})$, $3.58(\mathrm{dd}, J=8.3,6.1 \mathrm{~Hz}, 1 \mathrm{H}), 1.98(\mathrm{~s}, 3 \mathrm{H}), 1.40(\mathrm{~d}, J=6.5 \mathrm{~Hz}, 3 \mathrm{H})$.

${ }^{13} \mathrm{C}$ NMR $\left(125 \mathrm{MHz}, \mathrm{CDCl}_{3}\right) \delta 170.6,145.8,135.4,133.2,133.1,128.3,127.9,127.7,126.7$, $126.2,126.0,125.9,99.1,78.2,73.9,73.7,70.9,21.2,17.3$.

LRMS (ESI) m/z: [M+Na] $]^{+}$Calcd. for $\mathrm{C}_{19} \mathrm{H}_{20} \mathrm{O}_{4} \mathrm{Na}$ 335.13; Found 335.76 .

HRMS (ESI) m/z: [M+Na] ${ }^{+}$Calcd. for $\mathrm{C}_{19} \mathrm{H}_{20} \mathrm{O}_{4} \mathrm{Na}$ 335.1259; Found 335.1260.

$[\alpha]^{24}{ }_{\mathrm{D}}=-6.69\left(\mathrm{c}=0.0211, \mathrm{CH}_{2} \mathrm{Cl}_{2}\right)$ 


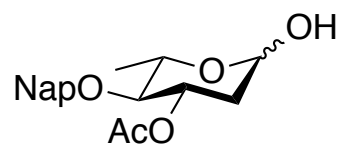

$(-)-8$
L-olivose

\section{3-O-acetyl-4-O-naphthyl-L-olivose (-)-8}

A solution of (-)-24 (0.411 g, $1.32 \mathrm{mmol})$ in THF $(7.69 \mathrm{~mL})$ was treated with triphenyl phosphine hydrogen bromide $(0.0906 \mathrm{~g}, 0.264 \mathrm{mmol})$. After stirring for 15 minutes, $\mathrm{H}_{2} \mathrm{O}(0.118 \mathrm{~mL}, 6.58$ mmol) was added. After stirring overnight, the reaction was quenched with sat. $\mathrm{NaHCO}_{3}(5 \mathrm{~mL})$ at $23{ }^{\circ} \mathrm{C}$, diluted with $\mathrm{H}_{2} \mathrm{O}$, and extracted with EtOAc $(3 \mathrm{x})$. The pooled organic layers were washed with $\mathrm{H}_{2} \mathrm{O}(1 \mathrm{x})$, brine (1x), dried over $\mathrm{Na}_{2} \mathrm{SO}_{4}$, filtered, and concentrated in vacuo. Purification by flash column chromatography on silica gel (30\% ethyl acetate in hexanes) afforded (-)-8 (0.392 g, $90 \%$ ) as a clear oil.

${ }^{1} \mathrm{H}$ NMR (500 MHz, $\left.\mathrm{CDCl}_{3}\right) \delta$ 7.85-7.38 (m, 7H), 5.40 - $5.34(\mathrm{~m}, 1 \mathrm{H}), 5.32(\mathrm{~s}, 1 \mathrm{H}), 4.89-4.83(\mathrm{~m}$, $2 \mathrm{H}), 4.10(\mathrm{dq}, J=9.4,6.3 \mathrm{~Hz}, 1 \mathrm{H}), 3.25(\mathrm{q}, J=9.0 \mathrm{~Hz}, 1 \mathrm{H}), 1.74-1.67(\mathrm{~m}, 1 \mathrm{H}), 1.31(\mathrm{~d}, J=6.3$ $\mathrm{Hz}, 3 \mathrm{H})$.

${ }^{13} \mathrm{C}$ NMR $\left(125 \mathrm{MHz}, \mathrm{CDCl}_{3}\right) \delta 170.6,135.7,133.0,128.2,128.2,127.9,127.7,126.4,126.2$, $126.1,125.9,125.8,125.7,93.4,91.6,82.7,81.9,74.7,71.5,71.3,67.3,38.2,35.6,21.2,21.1$, 18.3 .

LRMS (ESI) m/z: [M+Na $]^{+}$Calcd. for $\mathrm{C}_{19} \mathrm{H}_{22} \mathrm{O}_{5} \mathrm{Na} 353.14$; Found 353.70 .

HRMS (ESI) m/z: [M+Na $]^{+}$Calcd. for $\mathrm{C}_{19} \mathrm{H}_{22} \mathrm{O}_{5} \mathrm{Na}$ 353.1365; Found 353.1366.

$[\alpha]^{24}=-0.821\left(\mathrm{c}=0.0468, \mathrm{CH}_{2} \mathrm{Cl}_{2}\right)$

S3.3 Preparation of D-boivinose (+)-9

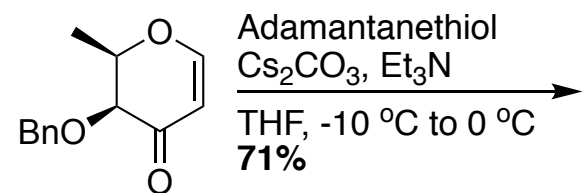

$(+)-6$<smiles></smiles>

$(+)-25$

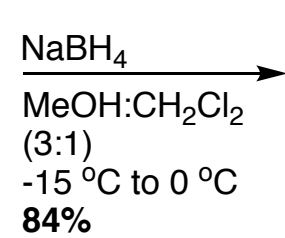

$84 \%$

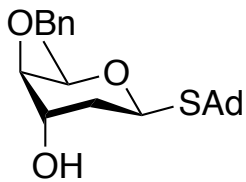

(+)-9

D-boivinose<smiles>C[C@@H]([SeH])[C@H]1CC(=O)[C@H](OCc2ccccc2)[C@@H](C)O1</smiles>

(+)-25 
The title compound was prepared according to a procedure adopted from Rodriguez. ${ }^{10}$ In a flamedried round bottom flask, cesium carbonate $(1.49 \mathrm{~g}, 4.58 \mathrm{mmol})$, adamantanethiol (3.08 $\mathrm{g}, 18.3$ $\mathrm{mmol})$, and triethyl amine $(0.640 \mathrm{~mL}, 4.58 \mathrm{mmol})$ were suspended in anhydrous THF $(30 \mathrm{~mL})$ and cooled to $-10{ }^{\circ} \mathrm{C}$ using a brine bath. After stirring for 5 minutes, a solution of enone $(+)-6(1.00 \mathrm{~g}$, $4.58 \mathrm{mmol})$ in anhydrous THF $(6.8 \mathrm{~mL})$ was added to the reaction flask at $-10{ }^{\circ} \mathrm{C}$. The reaction was allowed to gradually warm up and was held at $0{ }^{\circ} \mathrm{C}$ for 4 hours. After complete consumption of starting material, the reaction was diluted with $\mathrm{H}_{2} \mathrm{O}$ and extracted with EtOAc $(3 \mathrm{x})$. The pooled organic layers were washed with brine (1x), dried over $\mathrm{Na}_{2} \mathrm{SO}_{4}$, filtered, and concentrated in vacuo. Purification by flash column chromatography on silica gel (10\% ethyl acetate in hexanes) afforded (+)-25 (1.26 g, 71\%) as a single anomer as an oil.

${ }^{1} \mathrm{H}$ NMR $\left(500 \mathrm{MHz}, \mathrm{CDCl}_{3}\right) \delta$ 7.40-7.27 (m, 5H), $5.85(\mathrm{~d}, J=7.3 \mathrm{~Hz}, 1 \mathrm{H}), 4.95(\mathrm{~d}, J=11.5 \mathrm{~Hz}$, 1H), 4.57-4.47 (m, 2H), 3.58 (dd, $J=9.4,0.8 \mathrm{~Hz}, 1 \mathrm{H}), 3.04$ (ddd, $J=14.1,7.5,1.0 \mathrm{~Hz}, 1 \mathrm{H}), 2.55$ $(\mathrm{dd}, J=14.1,0.9 \mathrm{~Hz}, 1 \mathrm{H}), 2.03(\mathrm{~s}, 3 \mathrm{H}), 1.97-1.88(\mathrm{~m}, 6 \mathrm{H}), 1.72-1.65(\mathrm{~m}, 6 \mathrm{H}), 1.34(\mathrm{~d}, J=6.1 \mathrm{~Hz}$, $3 \mathrm{H})$.

${ }^{13} \mathrm{C} \mathrm{NMR}\left(125 \mathrm{MHz}, \mathrm{CDCl}_{3}\right) \delta$ 203.4, 137.6, 128.4, 128.2, 127.9, 84.7, 77.4, 73.2, 69.4, 47.3, 46.9, $43.6,36.2,29.8,18.5$.

LRMS (ESI) m/z: [M+Na $]^{+}$Calcd. for $\mathrm{C}_{23} \mathrm{H}_{30} \mathrm{O}_{3} \mathrm{SNa}$ 409.1813; Found 410.23.

HRMS (ESI) m/z: [M+Na] ${ }^{+}$Calcd. for $\mathrm{C}_{23} \mathrm{H}_{30} \mathrm{O}_{3} \mathrm{SNa} 409.1813$; Found 410.1812.

$[\alpha]^{24}=1.65\left(\mathrm{c}=0.0152, \mathrm{CH}_{2} \mathrm{Cl}_{2}\right)$

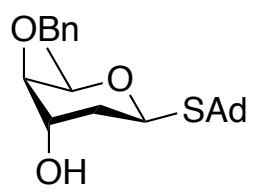

$(+)-9$

D-boivinose

4-O-benzyl-1-adamantanethiol- $\beta$-D-boivinose (+)-9

Ketone (+)-25 (1.25 g, $3.23 \mathrm{mmol})$ was dissolved in $\mathrm{MeOH}(28.6 \mathrm{~mL})$ and $\mathrm{CH}_{2} \mathrm{Cl}_{2}(9.5 \mathrm{~mL})$ and cooled to $-15{ }^{\circ} \mathrm{C}$ using a brine bath. $\mathrm{NaBH}_{4}(0.367 \mathrm{~g}, 9.69 \mathrm{mmol})$ was added in 3 portions to the solution at $-15{ }^{\circ} \mathrm{C}$ and the solution was allowed to gradually warm to $0{ }^{\circ} \mathrm{C}$. After 1 hour, upon which TLC indicated complete consumption of starting material, the reaction was quenched at 0 ${ }^{\circ} \mathrm{C}$ with sat. aq. $\mathrm{NH}_{4} \mathrm{Cl}(31 \mathrm{~mL})$ and acetone $(20 \mathrm{~mL})$. The reaction was diluted with $\mathrm{H}_{2} \mathrm{O}$ and extracted with $\mathrm{CH}_{2} \mathrm{Cl}_{2}(3 \mathrm{x})$. The pooled organic layers were washed with brine $(1 \mathrm{x})$, dried over $\mathrm{Na}_{2} \mathrm{SO}_{4}$, filtered, and concentrated in vacuo. Purification by flash column chromatography on silica gel (20\% ethyl acetate in hexanes) afforded (+)-9 (1.05 g, 84\%) as an amorphous solid. 
${ }^{1} \mathrm{H}$ NMR (500 MHz, $\left.\mathrm{CDCl}_{3}\right) \delta$ 7.38-7.28 (m, 5H), $5.49(\mathrm{dd}, J=6.5,1.4 \mathrm{~Hz}, 1 \mathrm{H}), 4.66(\mathrm{~d}, J=11.7$ $\mathrm{Hz}, 1 \mathrm{H}), 4.55$ (d, $J=11.7 \mathrm{~Hz}, 1 \mathrm{H}), 4.40$ (dq, $J=9.2,6.3 \mathrm{~Hz}, 1 \mathrm{H}), 4.22-4.17$ (m, $1 \mathrm{H}), 3.11$ (dd, $J$ $=9.2,3.2 \mathrm{~Hz}, 1 \mathrm{H}), 2.54(\mathrm{~s}, 1 \mathrm{H}), 2.22-2.15(\mathrm{~m}, 2 \mathrm{H}), 2.05-2.00(\mathrm{~m}, 3 \mathrm{H}), 1.96-1.89(\mathrm{~m}, 6 \mathrm{H}), 1.68(\mathrm{~s}$, $6 \mathrm{H}), 1.24(\mathrm{~d}, J=6.3 \mathrm{~Hz}, 3 \mathrm{H})$.

${ }^{13} \mathrm{C}$ NMR $\left(125 \mathrm{MHz}, \mathrm{CDCl}_{3}\right) \delta 137.8,128.5,127.9,127.7,80.4,74.2,71.1,63.9,62.4,45.8,43.7$, $36.8,36.4,29.8,17.8$.

LRMS (ESI) m/z: [M+Na $]^{+}$Calcd. for $\mathrm{C}_{23} \mathrm{H}_{32} \mathrm{O}_{3} \mathrm{SNa}$ 411.20; Found 411.93 .

HRMS (ESI) m/z: [M+Na] $]^{+}$Calcd. for $\mathrm{C}_{23} \mathrm{H}_{32} \mathrm{O}_{3} \mathrm{SNa}$ 411.1970; Found 411.1975.

$[\alpha]^{24} \mathrm{D}=0.080\left(\mathrm{c}=0.0996, \mathrm{CH}_{2} \mathrm{Cl}_{2}\right)$

S3.4 Preparation of D-oliose (+)-10<smiles>CC1OC=CC(=O)C1OCc1ccccc1</smiles>

$(+)-6$

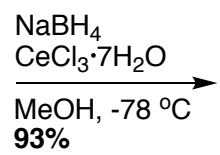

$93 \%$

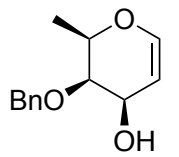

$(-)-26$

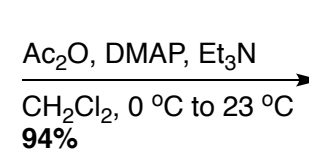

$94 \%$

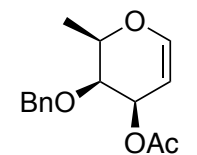

$(-)-27$

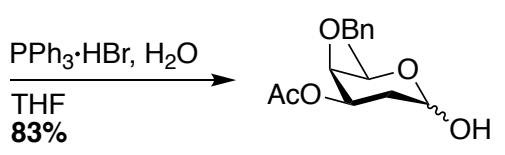

$(+)-10$<smiles>C[C@H]1OC=C[C@@H](O)[C@@H]1O[Hg]</smiles>

$(-)-26$

\section{4-O-benzyl-D-fucal (-)-26}

The title compound was prepared according to a procedure adopted from Venukumar. ${ }^{9}$ Enone (+)$6(1.00 \mathrm{~g}, 4.58 \mathrm{mmol})$ and $\mathrm{CeCl}_{3} \cdot 7 \mathrm{H}_{2} \mathrm{O}(2.56 \mathrm{~g}, 6.87 \mathrm{mmol})$ was dissolved in $\mathrm{MeOH}(16.7 \mathrm{~mL})$ and cooled to $-78{ }^{\circ} \mathrm{C}$ using a dry ice/acetone bath. In a separate round bottom flask, $\mathrm{NaBH}_{4}(0.260$ $\mathrm{g}, 6.87 \mathrm{mmol})$ was dissolved in $\mathrm{MeOH}(5.7 \mathrm{~mL})$ and cooled to $-10{ }^{\circ} \mathrm{C}$ using a brine bath. After stirring for 5 minutes at $-10{ }^{\circ} \mathrm{C}$, the $\mathrm{NaBH}_{4} / \mathrm{MeOH}$ solution was added dropwise via syringe to the flask with the enone at $-78{ }^{\circ} \mathrm{C}$. After 2 hours, upon which TLC indicated complete consumption of starting material, the reaction was quenched with sat. $\mathrm{NH}_{4} \mathrm{Cl}(25 \mathrm{~mL})$ at $-78{ }^{\circ} \mathrm{C}$ and the flask was subsequently removed from the bath and warmed to $23{ }^{\circ} \mathrm{C}$. The reaction was then diluted with $\mathrm{H}_{2} \mathrm{O}$ and extracted with EtOAc $(3 \mathrm{x})$. The pooled organic layers were washed with $\mathrm{H}_{2} \mathrm{O}(1 \mathrm{x})$, brine (1x), dried over $\mathrm{Na}_{2} \mathrm{SO}_{4}$, filtered, and concentrated in vacuo. Purification by flash column chromatography (30\% ethyl acetate on silica gel) on silica gel afforded (-)-26 (0.934 g, 93\%) as a single anomer.

${ }^{1} \mathrm{H}$ NMR (500 MHz, $\left.\mathrm{CDCl}_{3}\right) \delta$ 7.41-7.28 (m, 5H), $6.34(\mathrm{dd}, J=6.2,1.5 \mathrm{~Hz}, 1 \mathrm{H}), 4.83-4.74(\mathrm{~m}$, $2 \mathrm{H}), 4.70(\mathrm{ddd}, J=6.2,2.5,1.4 \mathrm{~Hz}, 1 \mathrm{H}), 4.41-4.33(\mathrm{~m}, 1 \mathrm{H}), 4.07$ (q, $J=6.7 \mathrm{~Hz}, 1 \mathrm{H}), 3.65(\mathrm{dt}, J$ $=5.0,1.4 \mathrm{~Hz}, 1 \mathrm{H}), 2.19-2.15(\mathrm{~m}, 1 \mathrm{H}), 1.33(\mathrm{~d}, J=6.7 \mathrm{~Hz}, 3 \mathrm{H})$. 
${ }^{13} \mathrm{C}$ NMR $\left(125 \mathrm{MHz}, \mathrm{CDCl}_{3}\right) \delta 144.6,137.8,128.56,128.2,128.1,102.7,76.0,75.3,72.7,64.1$, 16.7 .

LRMS (ESI) m/z: [M+Na] $]^{+}$Calcd. for $\mathrm{C}_{13} \mathrm{H}_{16} \mathrm{O}_{3} \mathrm{Na} 243.10$; Found 243.64 .

HRMS (ESI) m/z: [M+Na] $]^{+}$Calcd. for $\mathrm{C}_{13} \mathrm{H}_{16} \mathrm{O}_{3} \mathrm{Na}$ 243.0997; Found 243.0999.

$[\alpha]^{24} \mathrm{D}=-5.87\left(\mathrm{c}=0.188, \mathrm{CH}_{2} \mathrm{Cl}_{2}\right)$<smiles>CC(=O)OC1C=COC(C)C1[18O]C(C)=O</smiles>

$(-)-27$

3-O-acetyl-4-O-benzyl-D-fucal (-)-27

A solution of (-)-26 (0.500 g, $2.27 \mathrm{mmol}), \mathrm{Et}_{3} \mathrm{~N}(0.63 \mathrm{~mL}, 4.54 \mathrm{mmol})$, and 4Dimethylaminopyridine (103 mg, $0.0839 \mathrm{mmol})$ in $\mathrm{CH}_{2} \mathrm{Cl}_{2}(45 \mathrm{~mL})$ was cooled to $0{ }^{\circ} \mathrm{C}$. After cooling for 5 minutes, $\mathrm{Ac}_{2} \mathrm{O}(0.430 \mathrm{~mL}, 4.54 \mathrm{mmol})$ was added slowly to the reaction. The flask was promptly removed from the $0{ }^{\circ} \mathrm{C}$ ice bath and stirred at $23{ }^{\circ} \mathrm{C}$. After 1 hour, upon which TLC indicated complete consumption of the starting material, the reaction was concentrated in vacuo. Purification by flash column chromatography on silica gel (20\% ethyl acetate in hexanes) afforded (-)-27 (0.559 g, 94\%) as a clear oil.

${ }^{1} \mathrm{H}$ NMR $\left(500 \mathrm{MHz}, \mathrm{CDCl}_{3}\right) \delta$ 7.38-7.27 (m, 5H), $6.42(\mathrm{dd}, J=6.2,1.5 \mathrm{~Hz}, 1 \mathrm{H}), 5.50(\mathrm{ddt}, J=$ $4.5,3.0,1.4 \mathrm{~Hz}, 1 \mathrm{H}), 4.78$ (d, $J=11.9 \mathrm{~Hz}, 1 \mathrm{H}), 4.71$ (ddd, $J=6.2,3.1,1.2 \mathrm{~Hz}, 1 \mathrm{H}), 4.59$ (d, $J=$ $11.9 \mathrm{~Hz}, 1 \mathrm{H}), 4.19-4.11(\mathrm{~m}, 1 \mathrm{H}), 3.85-3.79(\mathrm{~m}, 1 \mathrm{H}), 2.06(\mathrm{~s}, 3 \mathrm{H}), 1.29(\mathrm{~d}, J=6.7 \mathrm{~Hz}, 3 \mathrm{H})$.

${ }^{13} \mathrm{C}$ NMR $\left(125 \mathrm{MHz}, \mathrm{CDCl}_{3}\right) \delta 170.9,145.9,138.0,128.4,128.1,127.8,98.0,73.9,72.9,72.4$, $66.4,21.2,15.7$.

LRMS (ESI) m/z: [M+Na] $]^{+}$Calcd. for $\mathrm{C}_{15} \mathrm{H}_{18} \mathrm{O}_{4} \mathrm{Na}$ 285.11; Found 285.64.

HRMS (ESI) m/z: [M+Na] $]^{+}$Calcd. for $\mathrm{C}_{15} \mathrm{H}_{18} \mathrm{O}_{4} \mathrm{Na} 285.1103$; Found 285.1104 .

$[\alpha]^{24} \mathrm{D}=-4.60\left(\mathrm{c}=0.0826, \mathrm{CH}_{2} \mathrm{Cl}_{2}\right)$

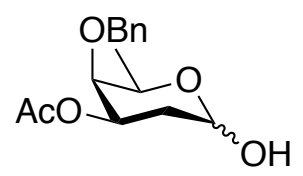

(+)-10

D-oliose

3-O-acetyl-4-O-benzyl-D-oliose (+)-10 
A solution of (-)-27 (0.494 g, $1.88 \mathrm{mmol})$ in THF $(11 \mathrm{~mL})$ was treated with triphenyl phosphine hydrogen bromide $(0.129 \mathrm{~g}, 0.376 \mathrm{mmol})$. After stirring for 15 minutes, $\mathrm{H}_{2} \mathrm{O}(0.170 \mathrm{~mL}, 9.40$ mmol) was added. After stirring overnight, the reaction was quenched with sat. $\mathrm{NaHCO}_{3}(5 \mathrm{~mL})$ at $23{ }^{\circ} \mathrm{C}$, diluted with $\mathrm{H}_{2} \mathrm{O}$, and extracted with EtOAc $(3 \mathrm{x})$. The pooled organic layers were washed with brine $(1 \mathrm{x})$, dried over $\mathrm{Na}_{2} \mathrm{SO}_{4}$, filtered, and concentrated in vacuo. Purification by flash column chromatography on silica gel (30 to $40 \%$ ethyl acetate in hexanes) afforded $(+)-10(0.436$ $\mathrm{g}, 83 \%$ ) as an amorphous solid.

${ }^{1} \mathrm{H}$ NMR $\left(500 \mathrm{MHz}, \mathrm{CDCl}_{3}\right) \delta$ 7.39-7.28 (m, 5H), $5.44(\mathrm{~s}, 1 \mathrm{H}), 5.30-5.25(\mathrm{~m}, 1 \mathrm{H}), 4.92-4.77(\mathrm{~m}$, $1 \mathrm{H}), 4.76-4.71(\mathrm{~m}, 1 \mathrm{H}), 4.64-4.59(\mathrm{~m}, 1 \mathrm{H}), 4.19(\mathrm{q}, J=6.5 \mathrm{~Hz}, 1 \mathrm{H}), 3.67(\mathrm{~s}, 1 \mathrm{H}), 3.60-3.49(\mathrm{~m}$, $1 \mathrm{H}), 2.49(\mathrm{~s}, 1 \mathrm{H}), 2.26-2.19(\mathrm{~m}, 1 \mathrm{H}), 2.01(\mathrm{~s}, 3 \mathrm{H}), 1.87(\mathrm{dd}, J=12.5,4.8 \mathrm{~Hz}, 1 \mathrm{H}), 1.18(\mathrm{~d}, J=6.5$ $\mathrm{Hz}, 3 \mathrm{H})$.

${ }^{13} \mathrm{C}$ NMR $\left(125 \mathrm{MHz}, \mathrm{CDCl}_{3}\right) \delta 170.4,138.3,128.3,128.3,128.3,127.9,127.8,94.2,92.4,76.4$, $75.2,75.1,75.0,72.1,70.9,69.8,66.5,33.7,30.0,21.2,21.1,17.1,17.0$.

LRMS (ESI) m/z: [M+Na] ${ }^{+}$Calcd. for $\mathrm{C}_{15} \mathrm{H}_{20} \mathrm{O}_{5} \mathrm{Na} 303.12$; Found 303.75 .

HRMS (ESI) m/z: [M+Na $]^{+}$Calcd. for $\mathrm{C}_{15} \mathrm{H}_{20} \mathrm{O}_{5} \mathrm{Na}$ 303.1208; Found 303.1210.

$[\alpha]^{24}=53.9\left(\mathrm{c}=0.242, \mathrm{CH}_{2} \mathrm{Cl}_{2}\right)$

3-O-acetyl-4-O-benzyl-1-O-tert-butyldimethylsilyl-D-oliose $\boldsymbol{S 1}$

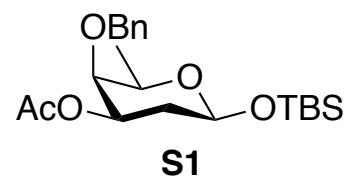

Compound (+)-10 (0.175 g, $0.624 \mathrm{mmol})$ and imidazole $(0.064 \mathrm{~g}, 0.936 \mathrm{mmol})$ were dissolved in DMF $(3.90 \mathrm{~mL})$. TBSCl $(0.113 \mathrm{~g}, 0.749 \mathrm{mmol})$ was then added to the stirred solution at $23{ }^{\circ} \mathrm{C}$. After 1 hour, upon which TLC indicated complete consumption of starting material, the reaction was quenched with methanol ( $5 \mathrm{~mL})$, diluted with $\mathrm{H}_{2} \mathrm{O}(40 \mathrm{~mL})$, and extracted with $\mathrm{CH}_{2} \mathrm{Cl}_{2}(3 \mathrm{x})$. The pooled organic layers were washed with $1 \mathrm{M} \mathrm{LiCl}(3 \mathrm{x})$, brine $(1 \mathrm{x})$, dried over $\mathrm{Na}_{2} \mathrm{SO}_{4}$, filtered, and concentrated in vacuo at $25^{\circ} \mathrm{C}$. Purification by flash column chromatography on silica gel (2 to $5 \%$ ethyl acetate in hexanes) afforded $\mathbf{S 1}(0.236 \mathrm{~g}, 91 \%)$ as a clear oil as a single anomer.

${ }^{1} \mathrm{H}$ NMR (300 MHz, $\left.\mathrm{C}_{6} \mathrm{D}_{6}\right) \delta 7.42-7.11(\mathrm{~m}, 5 \mathrm{H}), 4.86(\mathrm{ddd}, J=12.6,4.4,3.0 \mathrm{~Hz}, 1 \mathrm{H}), 4.75-$ $4.63(\mathrm{~m}, 2 \mathrm{H}), 4.45(\mathrm{~d}, J=11.7 \mathrm{~Hz}, 1 \mathrm{H}), 3.26(\mathrm{~s}, 1 \mathrm{H}), 3.07(\mathrm{q}, J=6.1 \mathrm{~Hz}, 1 \mathrm{H}), 2.46-2.30(\mathrm{~m}$, 1H), $2.09-1.96(\mathrm{~m}, 1 \mathrm{H}), 1.19(\mathrm{~d}, J=6.4 \mathrm{~Hz}, 3 \mathrm{H}), 1.07$ (s, 9H), 0.29 (s, 3H), 0.25 (s, 3H).

${ }^{13} \mathrm{C} \mathrm{NMR}\left(125 \mathrm{MHz}, \mathrm{CDCl}_{3}\right) \delta 170.52,138.49,128.21,127.61,94.87,75.07,74.97,72.46,70.66$, $34.52,25.82,21.12,18.13,17.09,-4.03,-5.09$.

HRMS (ESI) m/z: [M+Na $]^{+}$Calcd. for $\mathrm{C}_{21} \mathrm{H}_{34} \mathrm{O}_{5} \mathrm{SiNa}$ 417.2073; Found 417.2076. 
$[\alpha]^{24}=48.5\left(\mathrm{c}=0.273, \mathrm{CH}_{2} \mathrm{Cl}_{2}\right)$

S3.5 Preparation of L-ristosamine (-)-11<smiles>C[C@@H]1OC=CC(=O)[C@H]1O[N+]([O-])([O-])[O-]</smiles>

$(-)-5$ i.) $\mathrm{HSPh}, \mathrm{pyr} / \mathrm{Et}_{3} \mathrm{~N}$

ii.) $\mathrm{NH}_{2} \mathrm{OBn} \cdot \mathrm{HCl}, \mathrm{MeOH}$ $87 \%, 12.5: 1$ a: $\beta$<smiles>C[C@@H]1O[C@H](Sc2ccccc2)CC(=NOc2ccccc2)[C@@H]1O[N+]([O])([O-])O</smiles>

$(-)-28$

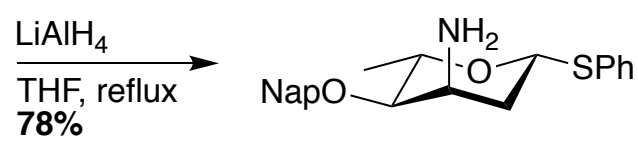

(-)-11

L-ristosamine<smiles>C[C@H]1O[C@H]([SbH]c2ccccc2)CC(=NOc2ccccc2)[C@@H]1O[N+](=O)[O-]</smiles>

$(-)-28$

4-O-naphthyl-O-benzyl-1-thio-2,6-dideoxy-L-erythro-hexopyranosid-3-ulose-oxime-1-thio-Lribo-hexopyranoside (-)-28

i. The title compound was prepared according to procedures adapted from both Giuliano ${ }^{11}$ and Scharf. ${ }^{12}$ Enone (-)-5 (1.00 g, $\left.5.88 \mathrm{mmol}\right)$ was dissolved in $5.0 \mathrm{~mL}$ of a pyridine/triethylamine stock solution ( $5 \mathrm{~mL}$ of pyridine $/ 3$ drops of triethylamine), and treated dropwise with thiophenol (0.660 mL, $6.47 \mathrm{mmol})$.

ii. After stirring the reaction mixture for 5 hours, the reaction was diluted with methanol $(2.90$ $\mathrm{mL}) . O$-benzylhydroxylamine hydrochloride $\left(\mathrm{NH}_{2} \mathrm{OBn} \cdot \mathrm{HCl}\right)(1.03 \mathrm{~g}, 6.47 \mathrm{mmol})$ was added as a solid and stirred at $23{ }^{\circ} \mathrm{C}$ for 16 hours. After TLC indicated the starting material was fully consumed, the reaction mixture was concentrated in vacuo at $20^{\circ} \mathrm{C}$ and the residue was purified by silica gel flash column chromatography (5\% to $10 \%$ ethyl acetate in hexanes) to afford (-)-28 $(1.96 \mathrm{~g}, 87 \%)$ as a white powder as a mixture of anomers $(12.5: 1 \alpha: \beta)$ that were not separated.

${ }^{1} \mathrm{H}$ NMR $\left(500 \mathrm{MHz}, \mathrm{CDCl}_{3}\right) \delta$ 7.89-7.28 (m, 17H), $5.42(\mathrm{t}, J=5.8 \mathrm{~Hz}, 1 \mathrm{H}), 5.25(\mathrm{~s}, 2 \mathrm{H}), 4.89(\mathrm{~d}$, $J=11.9 \mathrm{~Hz}, 1 \mathrm{H}), 4.59$ (d, $J=11.9 \mathrm{~Hz}, 1 \mathrm{H}), 4.51-4.43(\mathrm{~m}, 1 \mathrm{H}), 3.69$ (d, $J=6.6 \mathrm{~Hz}, 1 \mathrm{H}), 3.08$ (qd, $J=14.6,5.8 \mathrm{~Hz}, 2 \mathrm{H}), 1.29(\mathrm{~d}, J=6.5 \mathrm{~Hz}, 3 \mathrm{H})$.

${ }^{13} \mathrm{C}$ NMR $\left(125 \mathrm{MHz}, \mathrm{CDCl}_{3}\right) \delta 152.5,137.9,135.3,134.3,133.2,133.0,131.7,131.5,128.9$, $128.4,128.3,128.1,127.9,127.8,127.7,127.5,127.3,127.0,126.2,126.1,126.05,125.97,125.9$, $81.2,78.4,76.1,71.44,71.41,29.7,17.4$.

LRMS (ESI) m/z: $[\mathrm{M}+\mathrm{Na}]^{+}$Calcd. for $\mathrm{C}_{30} \mathrm{H}_{29} \mathrm{NO}_{3} \mathrm{SNa}$ 506.18; Found 507.03.

HRMS (ESI) m/z: [M+Na $]^{+}$Calcd. for $\mathrm{C}_{30} \mathrm{H}_{29} \mathrm{NO}_{3} \mathrm{SNa}$ 506.1766; Found 507.1769.

$[\alpha]^{24} \mathrm{D}=-2.30\left(\mathrm{c}=0.0736, \mathrm{CH}_{2} \mathrm{Cl}_{2}\right)$ 


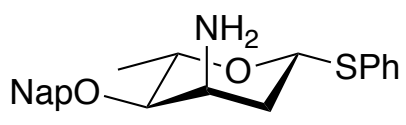

$(-)-11$

L-ristosamine

\section{4-O-naphthyl-1-thiophenol-L-ristosamine (-)-11}

In a flame-dried two-neck round bottom flask, (-)-28 $(0.500 \mathrm{~g}, 1.14 \mathrm{mmol})$ was added as a solution in THF $(15 \mathrm{~mL})$ and cooled to $0{ }^{\circ} \mathrm{C}$. $\mathrm{LiAlH}_{4}(95 \%$ by weight, $0.136 \mathrm{~g}, 3.42 \mathrm{mmol})$ was added as a solid at $0{ }^{\circ} \mathrm{C}$ and subsequently refluxed. After 3 hours, upon which TLC indicated complete consumption of starting material, the reaction was first allowed to cool to $23{ }^{\circ} \mathrm{C}$. The mixture was then further cooled to $0{ }^{\circ} \mathrm{C}$, quenched with sat. aq. $\mathrm{NH}_{4} \mathrm{Cl}(10 \mathrm{~mL})$, and then EtOAc $(10 \mathrm{~mL})$. After stirring for 15 minutes, sat. aq. Rochelle's Salt $(20 \mathrm{~mL})$ was added and the reaction was stirred vigorously for 3 hours until the grey solid became a fine powder. The resulting biphasic solution was separated, and the aqueous layer was extracted with EtOAc $(5 \mathrm{x})$. The pooled organic layers were washed with brine $(1 \mathrm{x})$, dried over $\mathrm{Na}_{2} \mathrm{SO}_{4}$, filtered, and concentrated in vacuo. Purification by flash column chromatography on silica gel (80 to 100\% ethyl acetate in hexanes) afforded (-)$11(0.336 \mathrm{~g}, 78 \%)$ as a viscous oil as a single anomer.

${ }^{1} \mathrm{H}$ NMR $\left(500 \mathrm{MHz}, \mathrm{CDCl}_{3}\right) \delta$ 7.89-7.45 (m, 7H), 7.30-7.20 (m, 5H), $5.43(\mathrm{dd}, J=6.1,2.4 \mathrm{~Hz}$, $1 \mathrm{H}), 4.79(\mathrm{~d}, J=11.9 \mathrm{~Hz}, 1 \mathrm{H}), 4.72(\mathrm{~d}, J=11.9 \mathrm{~Hz}, 1 \mathrm{H}), 4.50(\mathrm{dq}, J=12.7,6.3 \mathrm{~Hz}, 1 \mathrm{H}), 3.52$ (q, $J=4.0 \mathrm{~Hz}, 1 \mathrm{H}), 3.25(\mathrm{dd}, J=8.6,3.7 \mathrm{~Hz}, 1 \mathrm{H}), 2.29(\mathrm{ddd}, J=14.4,6.1,4.1 \mathrm{~Hz}, 1 \mathrm{H}), 2.16$ (ddd, $J$ $=14.5,4.2,2.5 \mathrm{~Hz}, 1 \mathrm{H}), 1.31(\mathrm{~d}, J=6.3 \mathrm{~Hz}, 3 \mathrm{H})$.

${ }^{13} \mathrm{C}$ NMR $\left(125 \mathrm{MHz}, \mathrm{CDCl}_{3}\right) \delta 136.9,135.6,133.3,133.0,130.8,128.8,128.2,127.9,127.7$, $126.8,126.5,126.2,126.0,125.7,82.4,80.8,71.3,63.9,45.6,37.1,17.9$.

LRMS (ESI) m/z: [M+Na $]^{+}$Calcd. for $\mathrm{C}_{23} \mathrm{H}_{25} \mathrm{NO}_{2} \mathrm{SNa} 402.15$; Found 402.99 .

HRMS (ESI) m/z: [M+Na] $]^{+}$Calcd. for $\mathrm{C}_{23} \mathrm{H}_{25} \mathrm{NO}_{2} \mathrm{SNa}$ 402.1504; Found 402.1505.

$[\alpha]^{24} \mathrm{D}=-1.25\left(\mathrm{c}=0.0423, \mathrm{CH}_{2} \mathrm{Cl}_{2}\right)$

S3.6 Preparation of L-Saccharosamine (-)-12

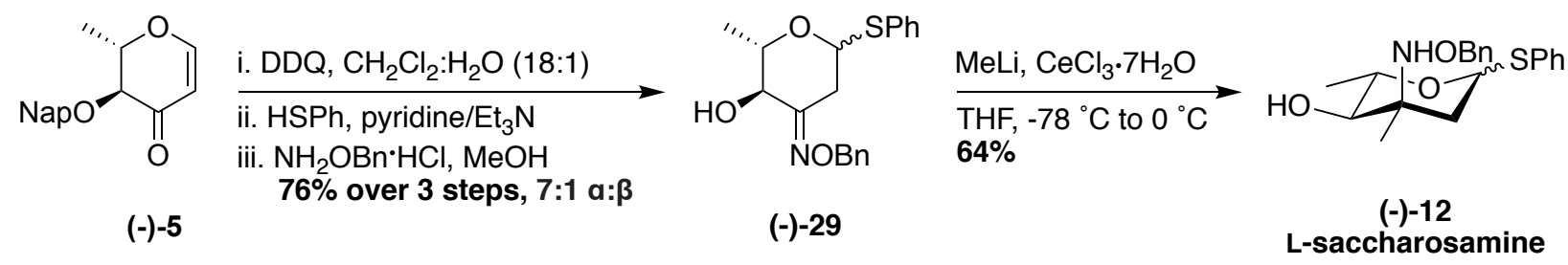




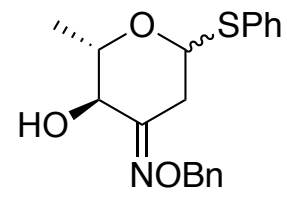

$(-)-29$

O-benzyl-1-thio-2,6-dideoxy-L-erythro-hexopyranosid-3-ulose-oxime-1-thio-L-ribohexopyranoside (-)-29

i. To a stirred solution of enone (-)-5 (0.500 g, $2.94 \mathrm{mmol})$ in $\mathrm{CH}_{2} \mathrm{Cl}_{2}(100 \mathrm{~mL})$ and $\mathrm{H}_{2} \mathrm{O}(5.56$ $\mathrm{mL}$ ) was added 2,3-dichloro-5,6-dicyano-1,4-benzoquinone (DDQ) (1.00 g, $4.41 \mathrm{mmol}$ ) as a solid at $23{ }^{\circ} \mathrm{C}$. ${ }^{13}$ The reaction progressed from black to green to orange over the course of 2 hours, upon which TLC indicated complete consumption of starting material. The reaction was diluted with $\mathrm{CH}_{2} \mathrm{Cl}_{2}$ and $\mathrm{H}_{2} \mathrm{O}$ and washed with sat. aq. $\mathrm{NaHCO}_{3}(3 \mathrm{x})$. The pooled aqueous layers were extracted with $\mathrm{CH}_{2} \mathrm{Cl}_{2}(3 \mathrm{x})$. The resulting organic layers were dried over $\mathrm{Na}_{2} \mathrm{SO}_{4}$, filtered, and concentrated in vacuo at $20{ }^{\circ} \mathrm{C}$. The residue was passed through a short silica plug to afford a white solid, but the resulting compound was found to sublime readily on both rotovap and high vacuum. The compound was carried forward with residual solvent present.

ii. The resulting crude compound $(0.376 \mathrm{~g})$ was dissolved in $1.89 \mathrm{~mL}$ of a pyridine/triethylamine stock solution ( $5 \mathrm{~mL}$ of pyridine $/ 3$ drops of triethylamine), and treated dropwise with thiophenol (0.330 mL, $3.23 \mathrm{mmol})$.

iii. After stirring the reaction mixture in step ii. for 5 hours, the reaction was diluted with methanol $(2.50 \mathrm{~mL})$. $O$-benzylhydroxylamine hydrochloride $\left(\mathrm{NH}_{2} \mathrm{OBn} \cdot \mathrm{HCl}\right)(0.516 \mathrm{~g}, 3.23 \mathrm{mmol})$ was added as a solid and stirred at $23{ }^{\circ} \mathrm{C}$ for 16 hours. After complete consumption of the starting material, the reaction mixture was concentrated in vacuo at $20^{\circ} \mathrm{C}$ and the residue was purified by flash column chromatography on silica gel $(20 \%$ ethyl acetate in hexanes) to afford (-)-29 $(0.767$ g, 76\% over three steps, 7:1 $\alpha: \beta$ ) as a slightly yellow oil as a mixture of anomers that were not separated. The spectroscopic data was in good agreement with previously reported values. ${ }^{11}$

${ }^{1} \mathrm{H}$ NMR $\left(500 \mathrm{MHz}, \mathrm{CDCl}_{3}\right) \delta$ 7.52-7.27 (m, 24H), $5.64(\mathrm{~d}, J=6.7 \mathrm{~Hz}, 1 \mathrm{H}), 5.19(\mathrm{~d}, J=2.7 \mathrm{~Hz}$, $2 \mathrm{H}), 5.10(\mathrm{~s}, 2 \mathrm{H}), 4.72(\mathrm{dd}, J=11.9,2.6 \mathrm{~Hz}, 1 \mathrm{H}), 4.20(\mathrm{dq}, J=9.3,6.2 \mathrm{~Hz}, 1 \mathrm{H}), 3.81(\mathrm{ddd}, J=$ 17.0, 9.4, 4.0 Hz, 2H), 3.66-3.57 (m, 2H), 3.44 (d, $J=4.3 \mathrm{~Hz}, 1 \mathrm{H}), 3.37$ (d, $J=3.7 \mathrm{~Hz}, 1 \mathrm{H}), 3.36-$ $3.30(\mathrm{~m}, 1 \mathrm{H}), 2.56(\mathrm{dd}, J=14.9,6.7 \mathrm{~Hz}, 1 \mathrm{H}), 2.15(\mathrm{dd}, J=14.7,11.9 \mathrm{~Hz}, 1 \mathrm{H}), 1.44(\mathrm{~d}, J=6.1 \mathrm{~Hz}$, $3 \mathrm{H})$.

${ }^{13} \mathrm{C}$ NMR $\left(125 \mathrm{MHz}, \mathrm{CDCl}_{3}\right) \delta 154.6,153.1,137.4,136.9,134.3,133.1,132.2,132.0,131.5$, $128.9,128.9,128.5,128.42,128.4,128.2,128.1,127.9,127.8,127.3,82.9,82.6,79.4,76.5,76.4$, 72.6, 72.1, 71.7, 31.8, 31.1, 18.5, 17.9.

LRMS (ESI) m/z: [M+Na] $]^{+}$Calcd. for $\mathrm{C}_{19} \mathrm{H}_{21} \mathrm{NO}_{3} \mathrm{SNa} 366.11$; Found 366.99 .

HRMS (ESI) m/z: [M+Na] $]^{+}$Calcd. for $\mathrm{C}_{19} \mathrm{H}_{21} \mathrm{NO}_{3} \mathrm{SNa}$ 366.1140; Found 366.1142.

$[\alpha]^{24}=-20.6\left(\mathrm{c}=0.983, \mathrm{CH}_{2} \mathrm{Cl}_{2}\right)$ 


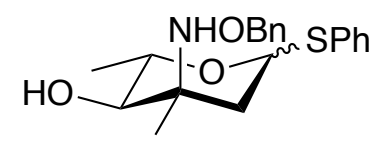

\section{$(-)-12$ \\ L-saccharosamine}

\section{3-(O-benzylhydroxylamine)-1-thiophenol-L-saccharosamine (-)-12}

The title compound was prepared according to a procedure adapted from Scharf. ${ }^{12}$ Cerium trichloride heptahydrate $\left(\mathrm{CeCl}_{3} \cdot 7 \mathrm{H}_{2} \mathrm{O}\right)(2.71 \mathrm{~g}, 7.28 \mathrm{mmol})$ was dried at $70{ }^{\circ} \mathrm{C}$ for 1 hour, $100{ }^{\circ} \mathrm{C}$ for 1 hour, then $140^{\circ} \mathrm{C}$ under vacuum overnight using a secondary trap apparatus with vigorous stirring. The resulting powder was cooled to $23{ }^{\circ} \mathrm{C}$ under vacuum and flushed with argon. Anhydrous THF $(23 \mathrm{~mL})$ was added and the resulting suspension was stirred for $20 \mathrm{~h}$ at $23{ }^{\circ} \mathrm{C}$ in the dark. The suspension was then cooled to $-78^{\circ} \mathrm{C}$ and $\mathrm{MeLi}(5.83 \mathrm{mmol}, 3.64 \mathrm{~mL}$ of $1.31 \mathrm{M}$ ether solution) was added dropwise at $-78{ }^{\circ} \mathrm{C}$. The yellow suspension was stirred for 1 hour, then a solution of compound (-)-29 $(0.500 \mathrm{~g}, 1.46 \mathrm{mmol})$ in THF $(3.72 \mathrm{~mL})$ was added dropwise at -78 ${ }^{\circ} \mathrm{C}$. The reaction mixture was stirred for 2.5 hours at $-78{ }^{\circ} \mathrm{C}$, then warmed to $0{ }^{\circ} \mathrm{C}$ and stirred for an additional hour. Upon complete consumption of starting material, the brown reaction mixture was quenched with sat. aq. $\mathrm{NaHCO}_{3}$ solution $(67 \mathrm{~mL})$ dropwise using an addition funnel. The reaction mixture was diluted with water $(300 \mathrm{~mL})$ and ether $(200 \mathrm{~mL})$, extracted with ether $(100$ $\mathrm{mL} \times 3$ ), dried over $\mathrm{Na}_{2} \mathrm{SO}_{4}$, filtered, and concentrated in vacuo. Purification by flash chromatography on silica gel (10 to 20\% ethyl acetate in hexanes) afforded (-)-12 (0.332 g, 64\%, $5: 1 \alpha: \beta)$ as a colorless oil. The spectroscopic data matched previously reported values. ${ }^{14}$

$\alpha$-anomer:

${ }^{1} \mathrm{H}$ NMR $\left(500 \mathrm{MHz}, \mathrm{CDCl}_{3}\right): \delta$ 7.48-7.46 (m, 2H), 7.42-7.28 (m, 7H), 7.25-7.23 (m, 1H), 6.35 (brs, 1H), $5.44(\mathrm{dd}, \mathrm{J}=6.6 \mathrm{~Hz}, \mathrm{~J}=1.4 \mathrm{~Hz}, 1 \mathrm{H}), 4.80(\mathrm{~s}, 2 \mathrm{H}), 4.14-4.11(\mathrm{~m}, 1 \mathrm{H}), 3.19(\mathrm{~d}, \mathrm{~J}=10.0$ $\mathrm{Hz}, 1 \mathrm{H}), 3.13(\mathrm{~d}, \mathrm{~J}=8.5 \mathrm{~Hz}, 1 \mathrm{H}), 2.23(\mathrm{dd}, \mathrm{J}=15.0 \mathrm{~Hz}, \mathrm{~J}=1.5 \mathrm{~Hz}, 1 \mathrm{H}), 2.04(\mathrm{dd}, \mathrm{J}=15.0 \mathrm{~Hz}, \mathrm{~J}$ $=6.5 \mathrm{~Hz}, 1 \mathrm{H}), 1.28(\mathrm{~s}, 3 \mathrm{H}), 1.26(\mathrm{~d}, \mathrm{~J}=5.0 \mathrm{~Hz}, 3 \mathrm{H})$.

${ }^{13} \mathrm{C}$ NMR $\left(125 \mathrm{MHz}, \mathrm{CDCl}_{3}\right): \delta 137.3,136.1,131.6,129.0,128.8,128.7,128.6,128.6,128.2$, $127.8,127.3,127.1,83.0,78.8,77.4,66.3,58.1,39.0,23.6,18.4$.

HRMS (ESI) m/z: [M+Na] ${ }^{+}$Calcd. for $\mathrm{C}_{20} \mathrm{H}_{25} \mathrm{NO}_{3} \mathrm{SNa} 382.1453$; Found 383.1454.

$[\alpha]^{24}=-25.8\left(\mathrm{c}=0.886, \mathrm{CH}_{2} \mathrm{Cl}_{2}\right)$

$\beta$-anomer:

${ }^{1} \mathrm{H}$ NMR $\left(500 \mathrm{MHz}, \mathrm{CDCl}_{3}\right): \delta$ 7.46-7.44 (m, 2H), 7.33-7.26 (m, 6H), 7.25-7.24 (m, 2H), 5.61 (brs, $1 \mathrm{H}), 5.13(\mathrm{dd}, \mathrm{J}=11.9 \mathrm{~Hz}, \mathrm{~J}=2.1 \mathrm{~Hz}, 1 \mathrm{H}), 4.66\left(\mathrm{ABq}, \mathrm{J}=11.6 \mathrm{~Hz}, \Delta v_{\mathrm{AB}}=10.4 \mathrm{~Hz}, 2 \mathrm{H}\right)$, 3.78-3.75 (m, 1H), $3.16(\mathrm{dd}, \mathrm{J}=9.5 \mathrm{~Hz}, \mathrm{~J}=7.0 \mathrm{~Hz}, 1 \mathrm{H}), 2.52(\mathrm{~d}, \mathrm{~J}=7.0 \mathrm{~Hz}, 1 \mathrm{H}), 2.17$ (dd, J = $14.0 \mathrm{~Hz}, \mathrm{~J}=2.0 \mathrm{~Hz}, 1 \mathrm{H}), 1.67(\mathrm{dd}, \mathrm{J}=14.0 \mathrm{~Hz}, \mathrm{~J}=12.0 \mathrm{~Hz}, 1 \mathrm{H}), 1.30-1.26(\mathrm{~m}, 6 \mathrm{H})$.

${ }^{13} \mathrm{C} \mathrm{NMR}\left(125 \mathrm{MHz}, \mathrm{CDCl}_{3}\right): \delta 137.3,136.1,131.6,129.0,128.9,128.8,128.6,128.2,127.3,83.0$, $78.8,66.3,58.2,39.0,23.6,18.4$. 
HRMS (ESI) m/z: [M+Na] $]^{+}$Calcd. for $\mathrm{C}_{20} \mathrm{H}_{25} \mathrm{NO}_{3} \mathrm{SNa}$ 382.1453; Found 383.1456.

$[\alpha]^{24} \mathrm{D}=-32.6\left(\mathrm{c}=0.756, \mathrm{CH}_{2} \mathrm{Cl}_{2}\right)$

References:

(1) Lagisetti, C.; Yermolina, M. V.; Sharma, L. K.; Palacios, G.; Prigaro, B. J.; Webb, T. R. Pre-MRNA Splicing-Modulatory Pharmacophores: The Total Synthesis of Herboxidiene, a Pladienolide-Herboxidiene Hybrid Analog and Related Derivatives. ACS Chem. Biol. 2014, 9, 643-648.

(2) Ito, Y.; Kobayashi, Y.; Kawabata, T.; Takase, M.; Terashima, S. Novel Syntheses of the Carbapenem Key Intermediates, (3R,4R)-4-Acetoxy-3-[(R)-1-(t-

Butyldimethylsilyloxy)Ethyl]-2-Azetidinone and (3S,4R)-3-[(R)-1-(t-

Butyldimethylsilyloxy)Ethyl]-4-Carboxymethyl-2-Azetidinone, from (S)-Ethyl Lactate. Tetrahedron 1989, 45, 5767-5790.

(3) Marshall, J. A.; Bourbeau, M. P. Synthesis of Enantioenriched Propargylic Alcohols Related to Polyketide Natural Products. A Comparison of Methodologies. Org. Lett. 2003, 5, 3197-3199.

(4) Fukui, H.; Shiina, I. Asymmetric Total Synthesis of Botcinins C, D, and F. Org. Lett. 2008, 10, 3153-3156.

(5) Bae, H. J.; Jeong, W.; Lee, J. H.; Rhee, Y. H. Gold(I)-Catalyzed Access to Tetrahydropyran-4-Ones from 4-(Alkoxyalkyl)Oxy-1-Butynes: Formal Catalytic PetasisFerrier Rearrangement. Chem. - A Eur. J. 2011, 17, 1433-1436.

(6) Kim, J.; Jeong, W.; Rhee, Y. H. Flexible Tetrahydropyran Synthesis from Homopropargylic Alcohols Using Sequential Pd-Au Catalysis. Org. Lett. 2017, 19, 242 245.

(7) Kirschning, A. Oxidation of Fully Protected Glycals by Hypervalent Iodine Reagents. $J$. Org. Chem. 1995, 60, 1228-1232.

(8) Soliman, S. E.; Bennett, C. S. Reagent-Controlled Synthesis of the Branched Trisaccharide Fragment of the Antibiotic Saccharomicin B. Org. Lett. 2018, 20, 34133417.

(9) Sridhar, P. R.; Venukumar, P. A Ring Expansion-Glycosylation Strategy toward the Synthesis of Septano-Oligosaccharides. Org. Lett. 2012, 14, 5558-5561.

(10) Ganguly, D.; Tang, H.; Rodriguez, M. J. Cesium Carbonate-Promoted Michael-Type Addition of Thiols to Hex-1-En-3-Ulose: A Practical Synthesis of 2-Deoxy-1-Thio- $\alpha$ Hexopyranosid- 3-Ulose Template. Synth. Commun. 2007, 37, 4219-4226.

(11) Noecker, L.; Duarte, F.; Bolton, S. A.; McMahon, W. G.; Diaz, M. T.; Giuliano, R. M. Glycosylation of Branched Amino and Nitro Sugars. 2. Synthesis of the Cororubicin Trisaccharide. J. Org. Chem. 1999, 64, 6275-6282.

(12) Greven, R.; Jütten, P.; Scharf, H. D. A New Stereoselective Route to Branched-Chain Nitro and Amino Sugars: Synthesis of Both Enantiomers of Decilonitrose and Avidinosamine. J. Org. Chem. 1993, 58, 3742-3747.

(13) Kim, H. M.; Kim, I. J.; Danishefsky, S. J. Total Syntheses of Tumor-Related Antigens 
N3: Probing the Feasibility Limits of the Glycal Assembly Method. J. Am. Chem. Soc. 2001, 123, 35-48.

(14) Bylsma, M.; Bennett, C. S. Stereospecific Synthesis of the Saccharosamine-RhamnoseFucose Fragment Present in Saccharomicin B. Org. Lett. 2018, 20, 4695-4698. 
${ }^{1} \mathrm{H}$ NMR of $(+)-14 \quad\left(500 \mathrm{MHz}, \mathrm{CDCl}_{3}\right)$

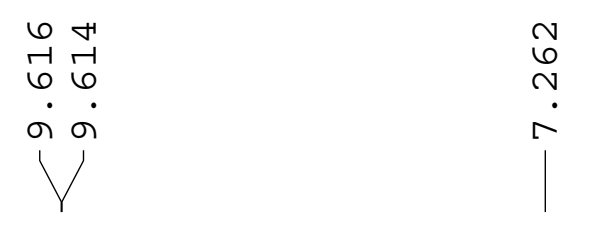

$6+m \circ \sigma 6$ เ $m$

तु

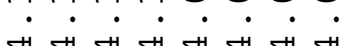

$\longrightarrow$<smiles>CCC=O</smiles>

ŌTBS

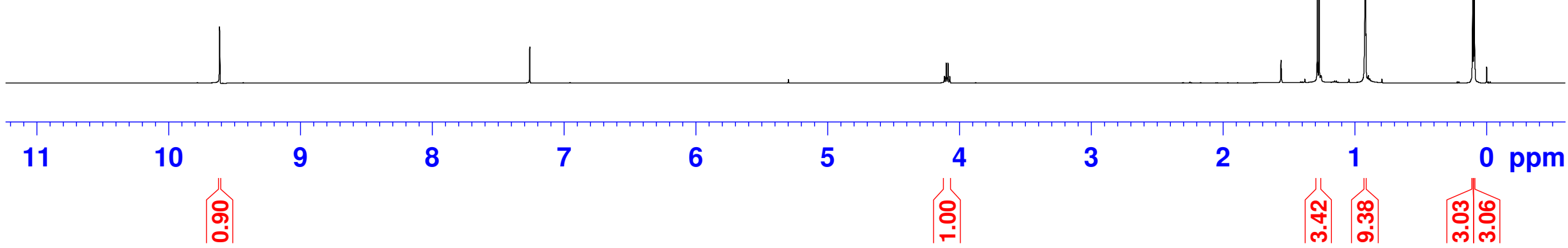


${ }^{13} \mathbf{C}$ of (+)-14 (125 $\left.\mathrm{MHz}, \mathrm{CDCl}_{3}\right)$
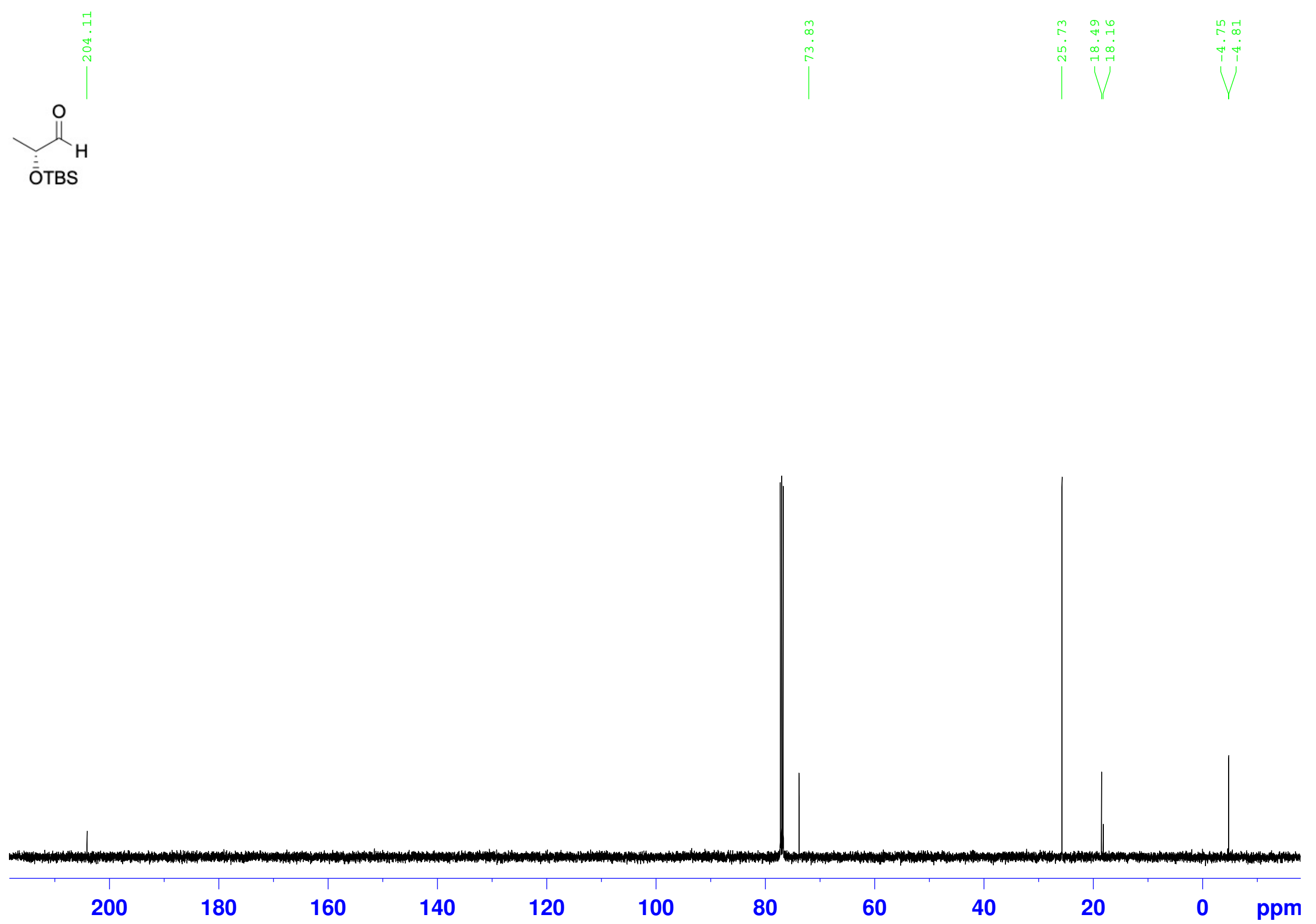
${ }^{1} \mathrm{H}$ NMR of (-)-15 (500 $\left.\mathrm{MHz}, \mathrm{CDCl}_{3}\right)$

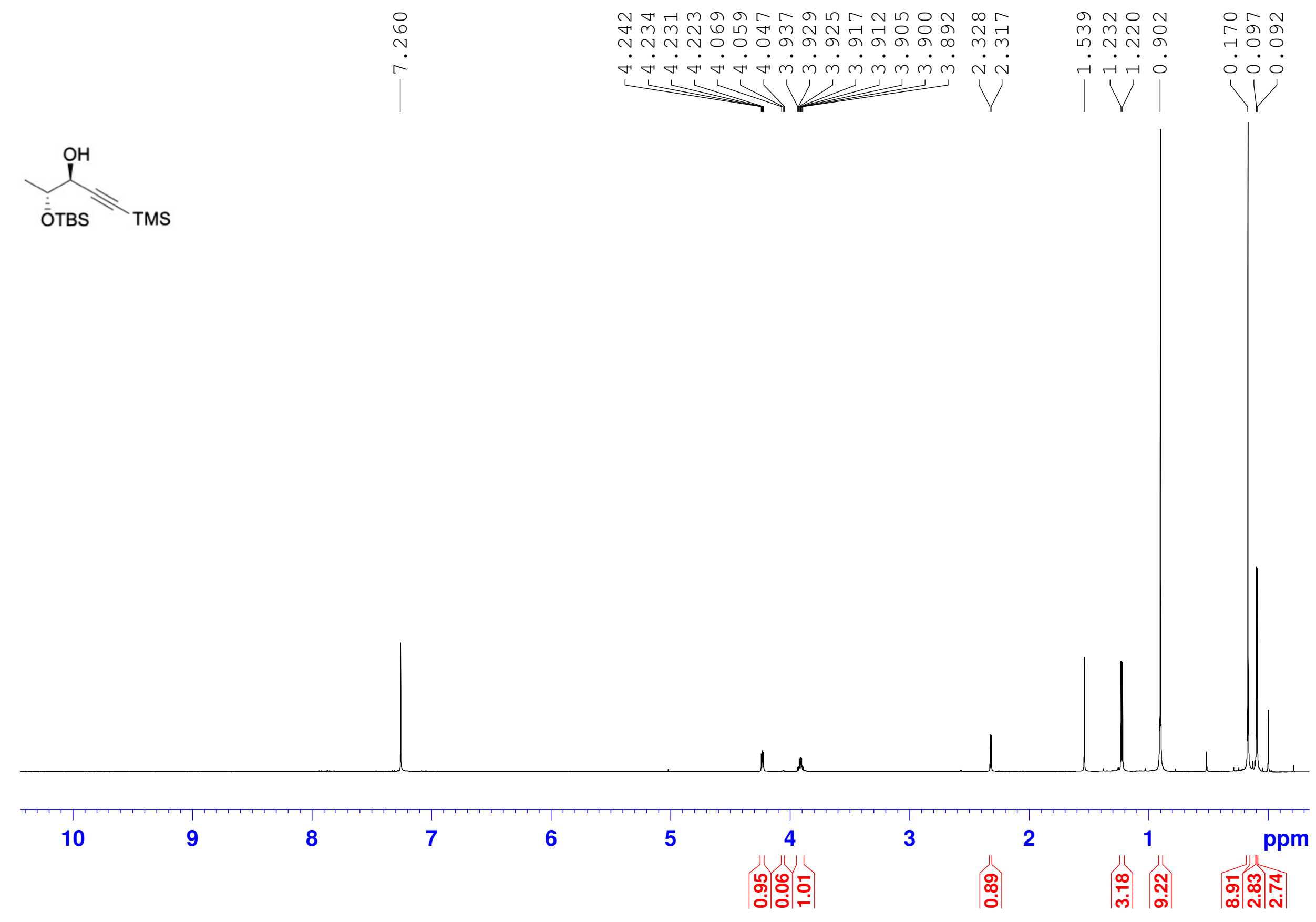


${ }^{13} \mathrm{C}$ NMR of (-)-15 (125 $\left.\mathrm{MHz}, \mathrm{CDCl}_{3}\right)$
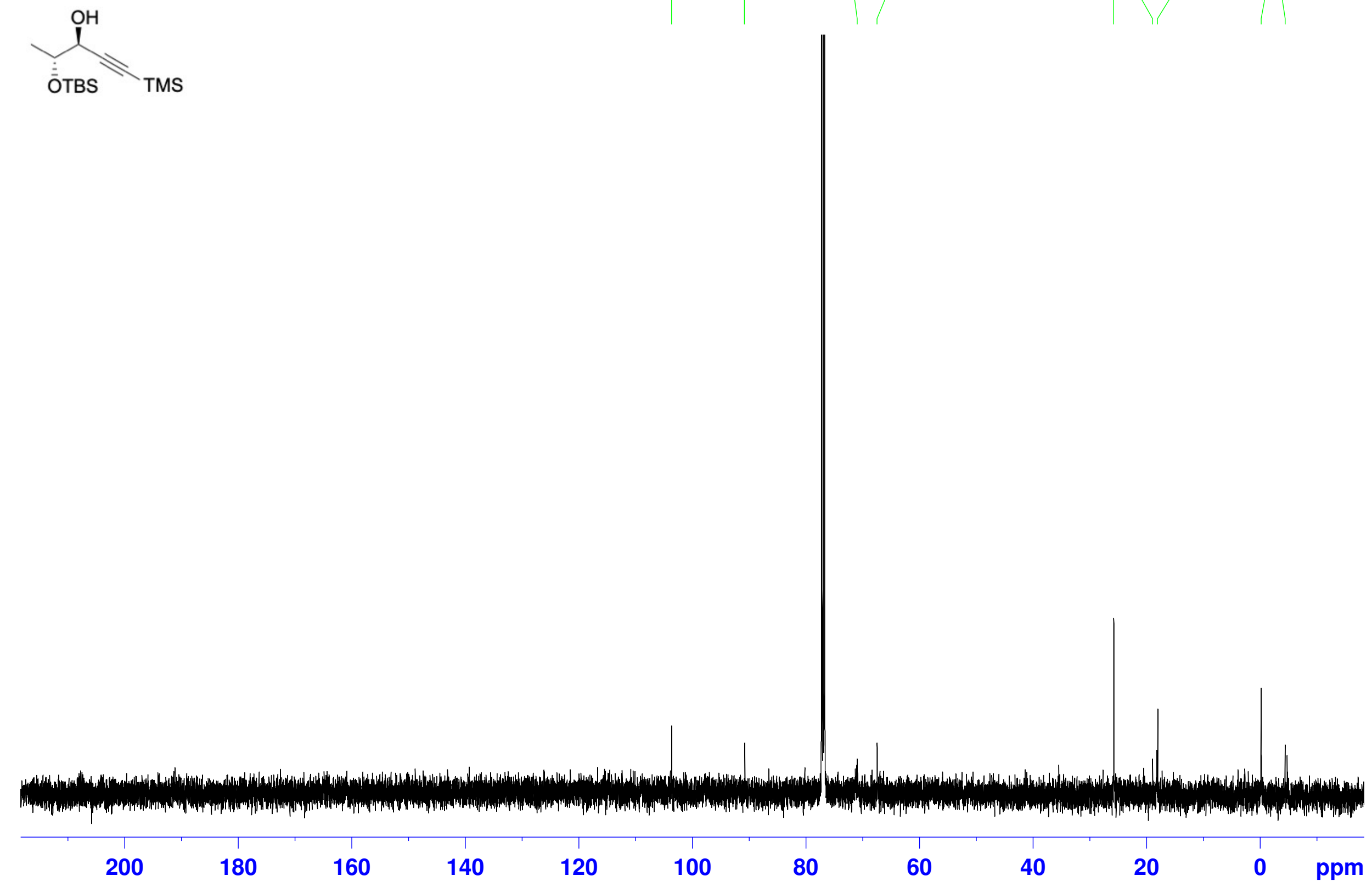
${ }^{1} \mathrm{H}$ NMR of (-)-16 (500 MHz, $\left.\mathrm{CDCl}_{3}\right)$

H人 m

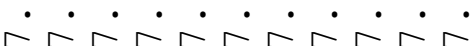

๘ ๓ $\dot{\sigma} \dot{\gamma} \dot{\sigma} \dot{m} \dot{m} \dot{m} \dot{m} \dot{m} \dot{m} \dot{m} \dot{m}$

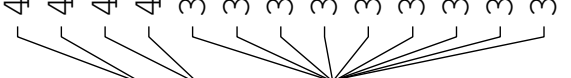

$\sim \infty$

$\underset{\forall}{\infty}$

.

$\infty 6\llcorner\mathrm{~m} \sim$

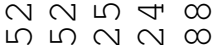
. $\cdot$.

नम न

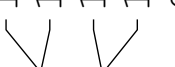

๑) 000 $\circ \dot{0} 0$

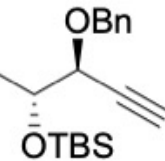

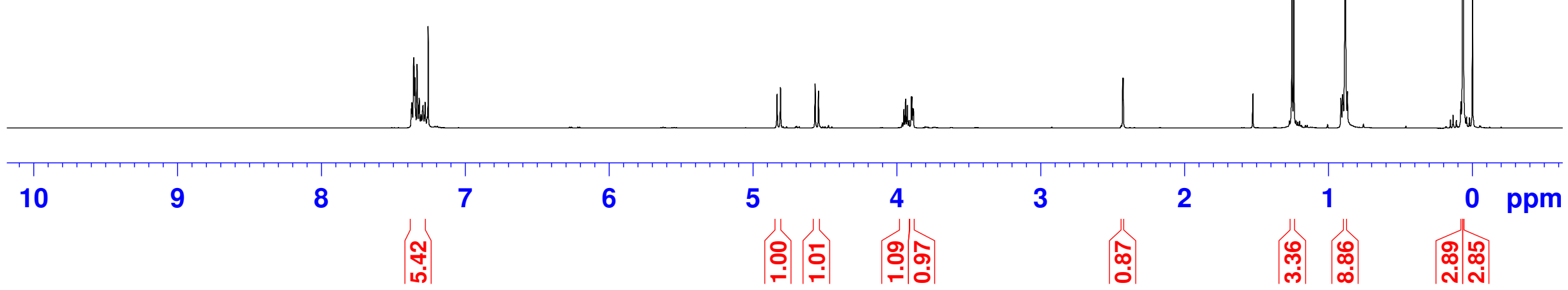


${ }^{13} \mathrm{C}$ NMR of $(-)-16\left(125 \mathrm{MHz}, \mathrm{CDCl}_{3}\right)$
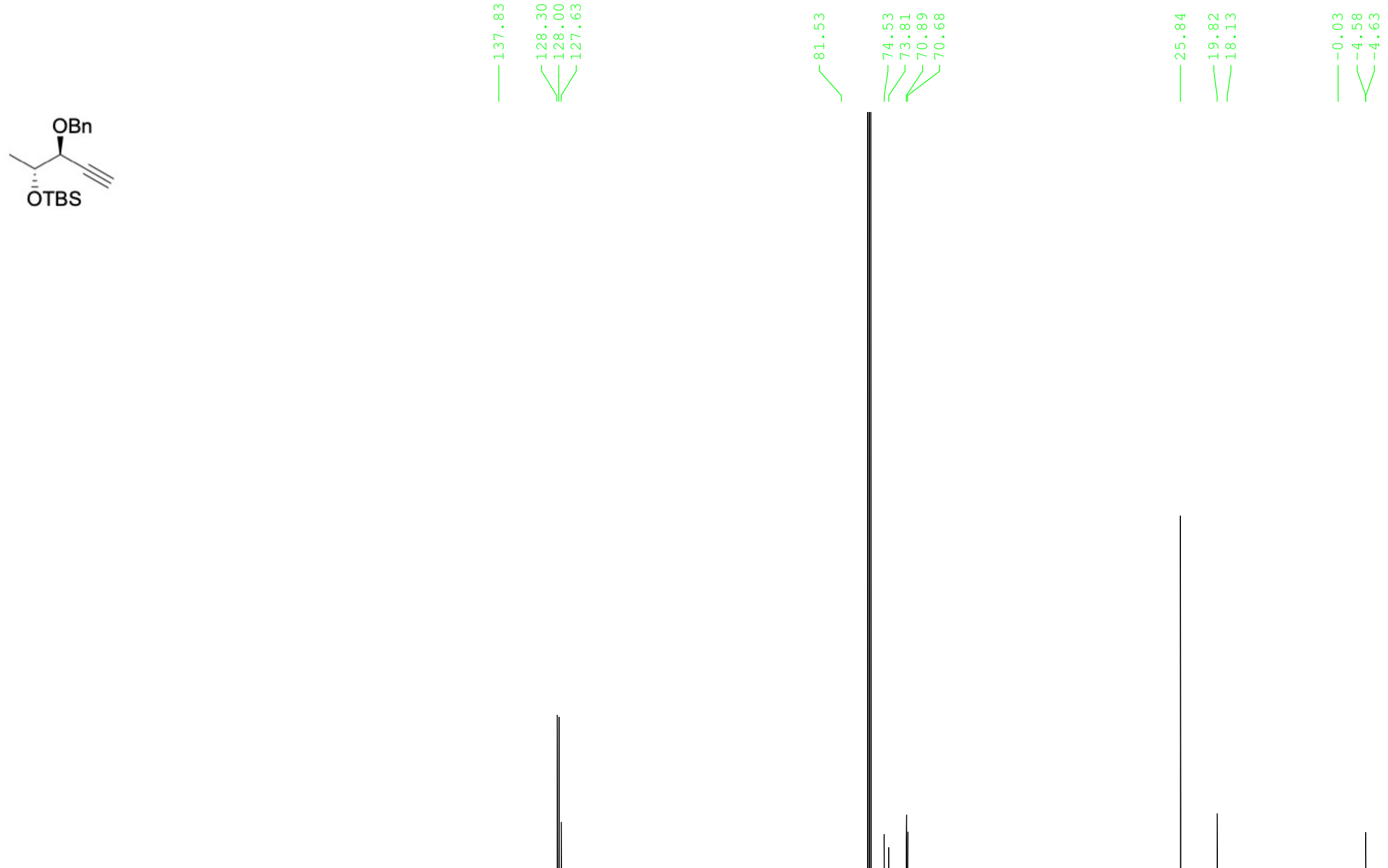

\begin{tabular}{llllllllll|l|l|l|l|l|l}
\hline 200 & 180 & 160 & 140 & 120 & 100 & 80 & 60 & 40 & 20 & 0 & ppm
\end{tabular}


${ }^{1} \mathrm{H}$ NMR of (-)-17 (500 $\left.\mathrm{MHz}, \mathrm{CDCl}_{3}\right)$

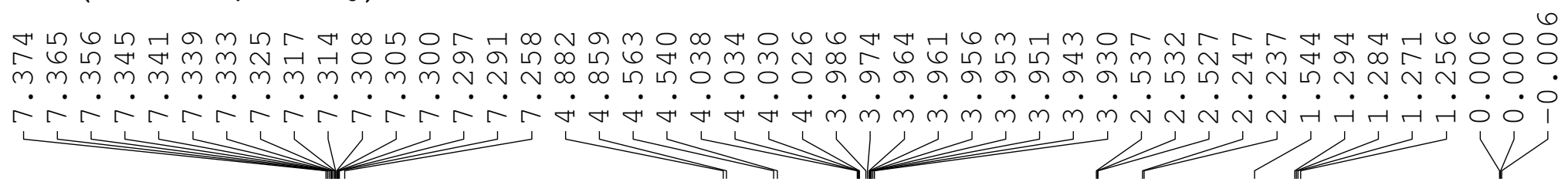<smiles>C#C[C@H](O)[C@@H](C)O</smiles>

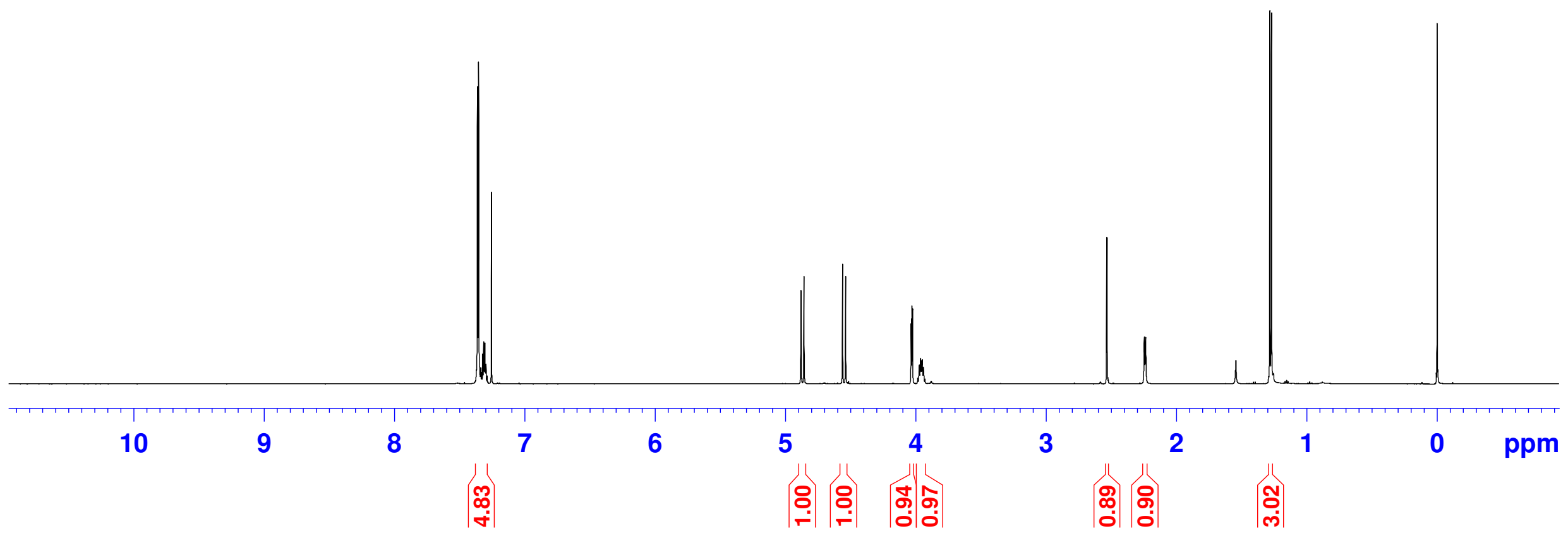


${ }^{13} \mathbf{C}$ NMR of $(-)-17\left(125 \mathrm{MHz}, \mathrm{CDCl}_{3}\right)$
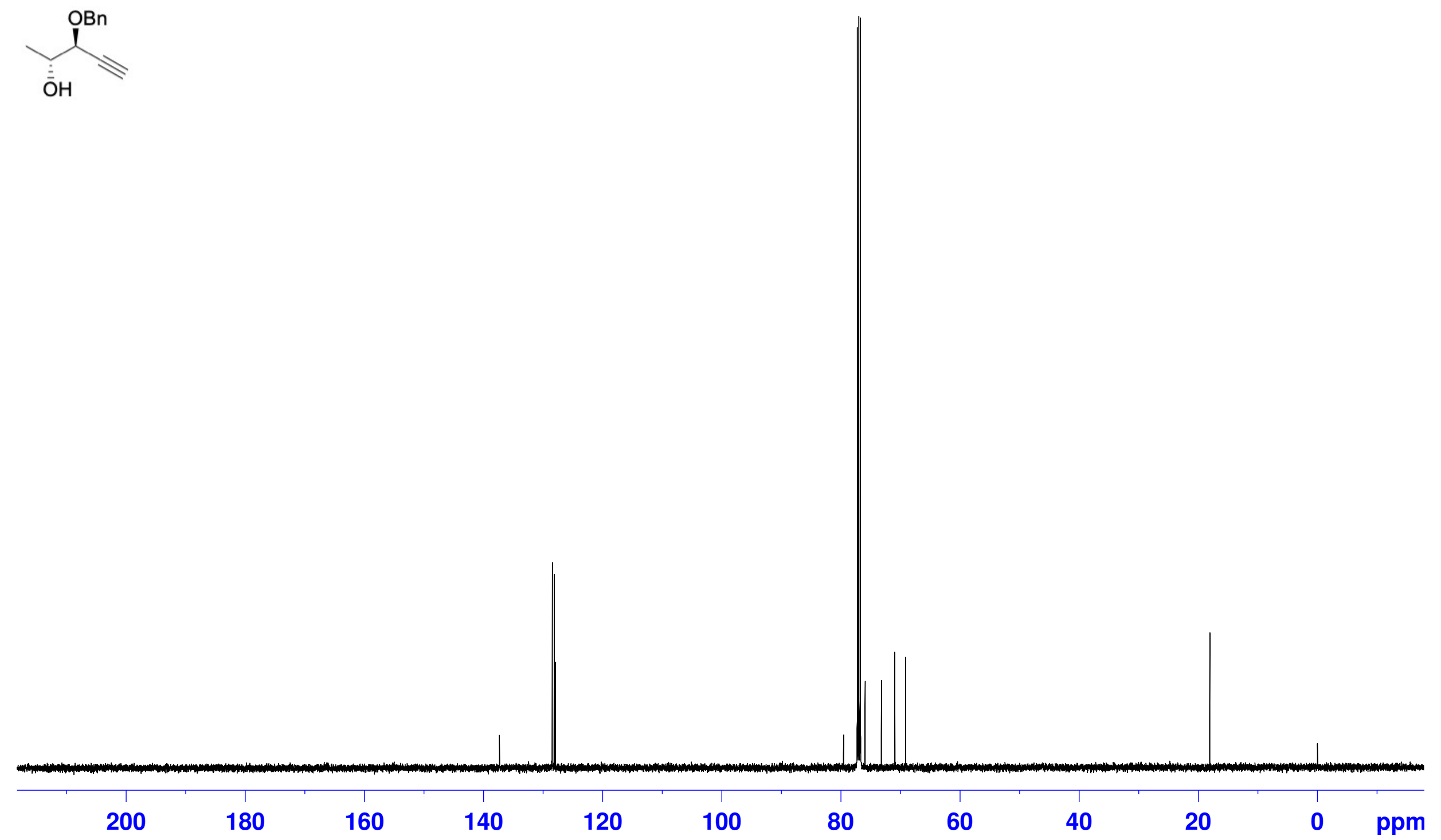
${ }^{1} \mathbf{H}$ NMR of $1\left(500 \mathrm{MHz}, \mathrm{C}_{6} \mathrm{D}_{6}\right)$
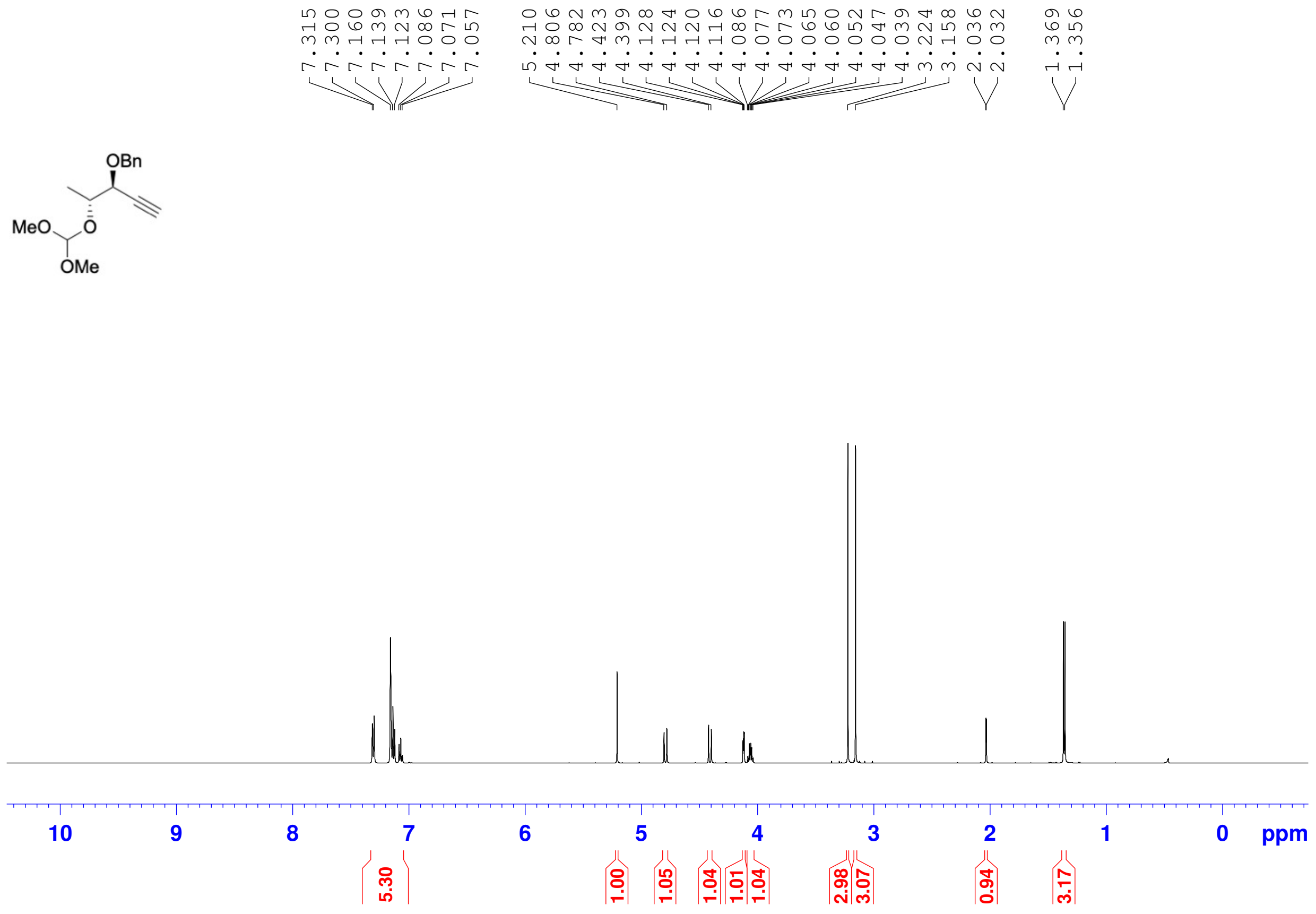
${ }^{13} \mathbf{C}$ NMR of (-)-1 (125 $\left.\mathrm{MHz}, \mathrm{C}_{6} \mathrm{D}_{6}\right)$
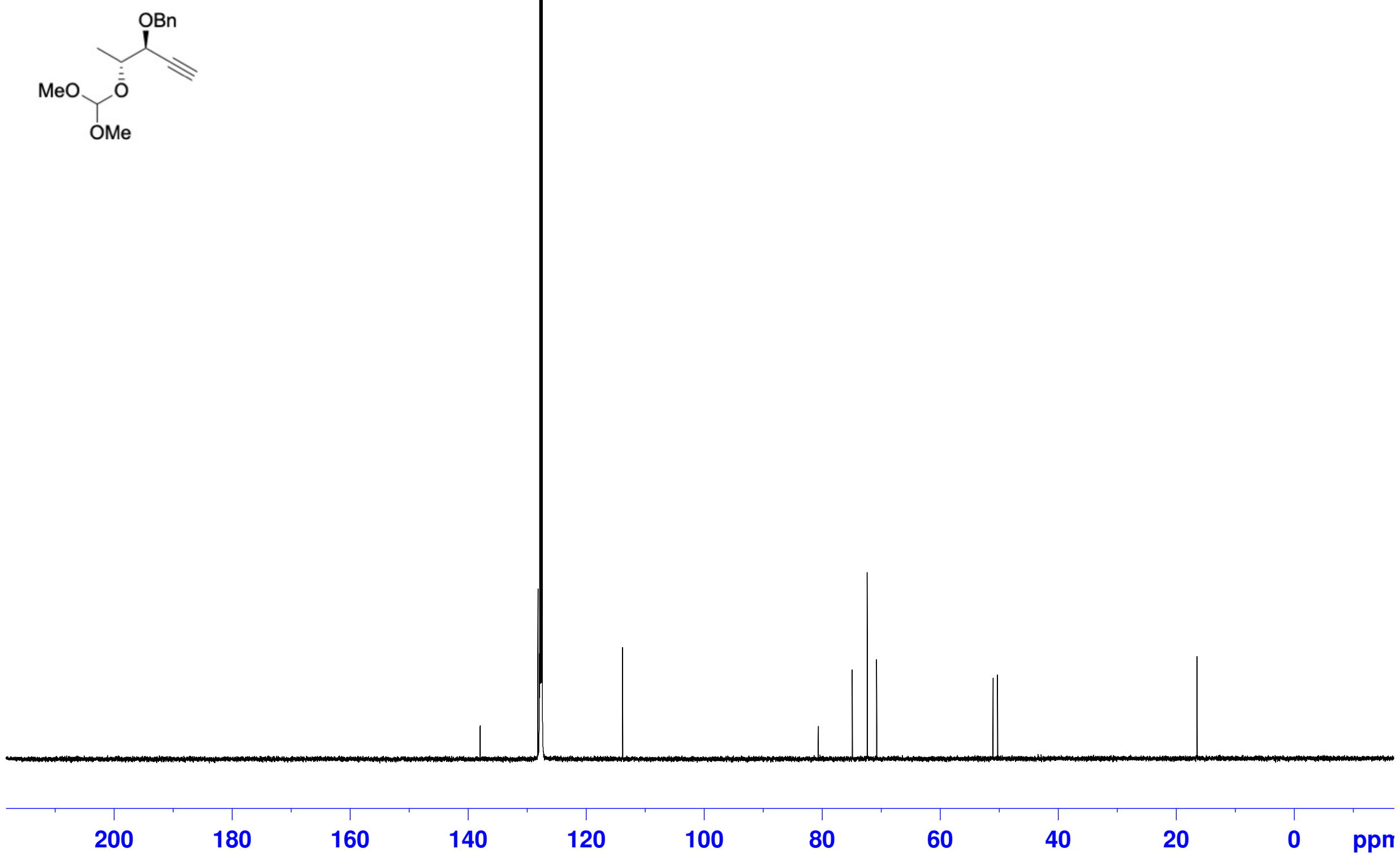
${ }^{1} \mathrm{H}$ NMR of $(-)-14\left(500 \mathrm{MHz}, \mathrm{CDCl}_{3}\right)$
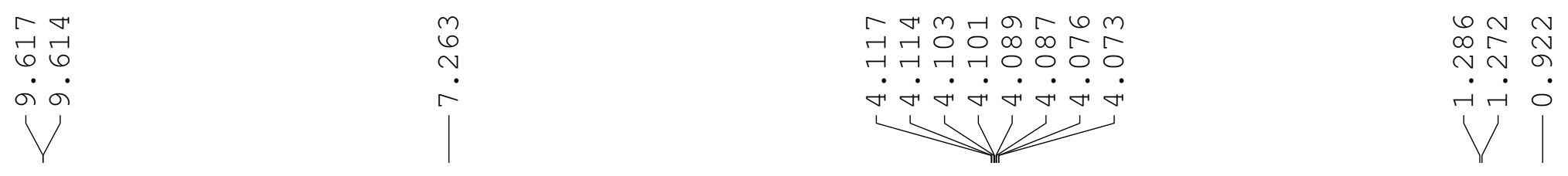

망

궁․

10

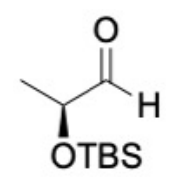

,

5

8

7

6

(ㅇ.

3

?.

4

$\left|\begin{array}{ll}\text { N̦ } \\ \text { m. }\end{array}\right|$

0 ppm

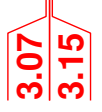


${ }^{13} \mathrm{C}$ NMR of $(-)-14\left(125 \mathrm{MHz}, \mathrm{CDCl}_{3}\right)$
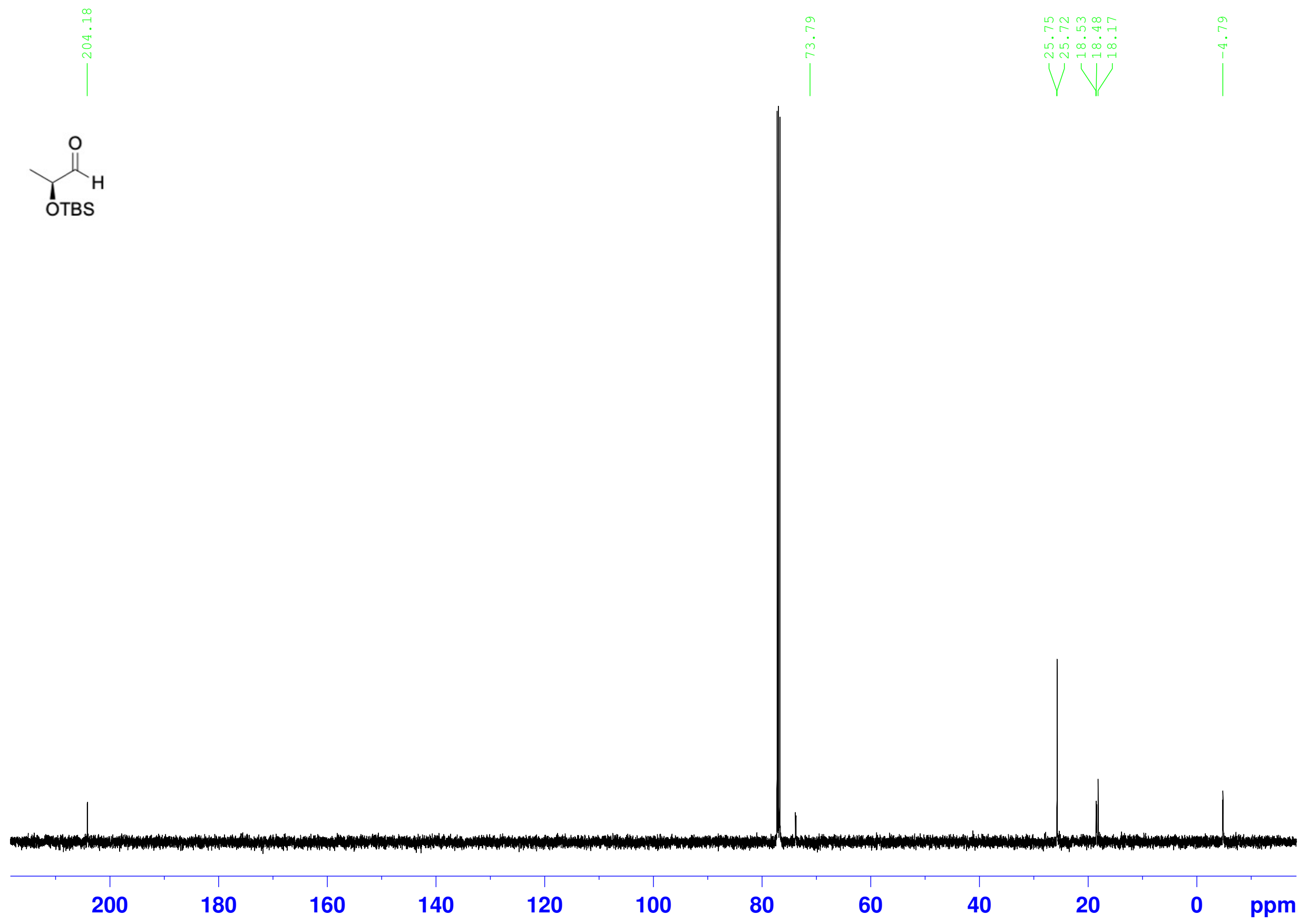
${ }^{1} \mathrm{H}$ NMR of $(+)-15\left(500 \mathrm{MHz}, \mathrm{CDCl}_{3}\right)$
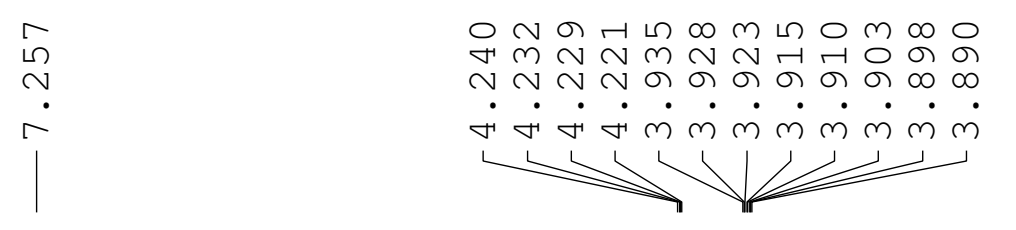

$\bigcirc 0$

$m$ m

$\therefore$

$6 \circ \infty$ 늠더우

เา ำ.

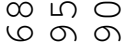

नंत्

․․

V

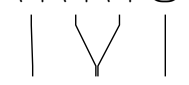

000<smiles>CC(C)O[Sb](C)(=O)=O</smiles>

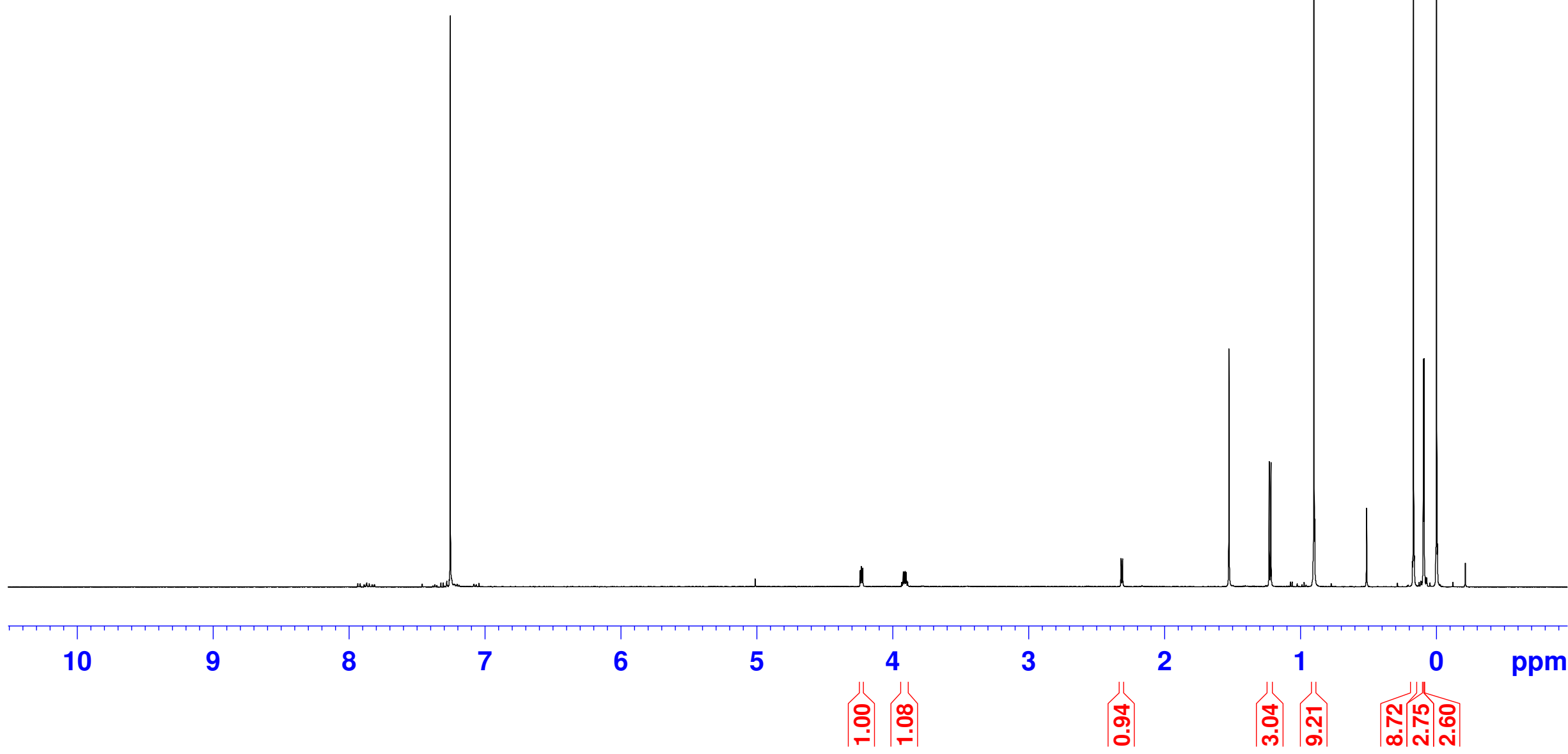


${ }^{13} \mathrm{C}$ NMR of (+)-15 (125 $\left.\mathrm{MHz}, \mathrm{CDCl}_{3}\right)$
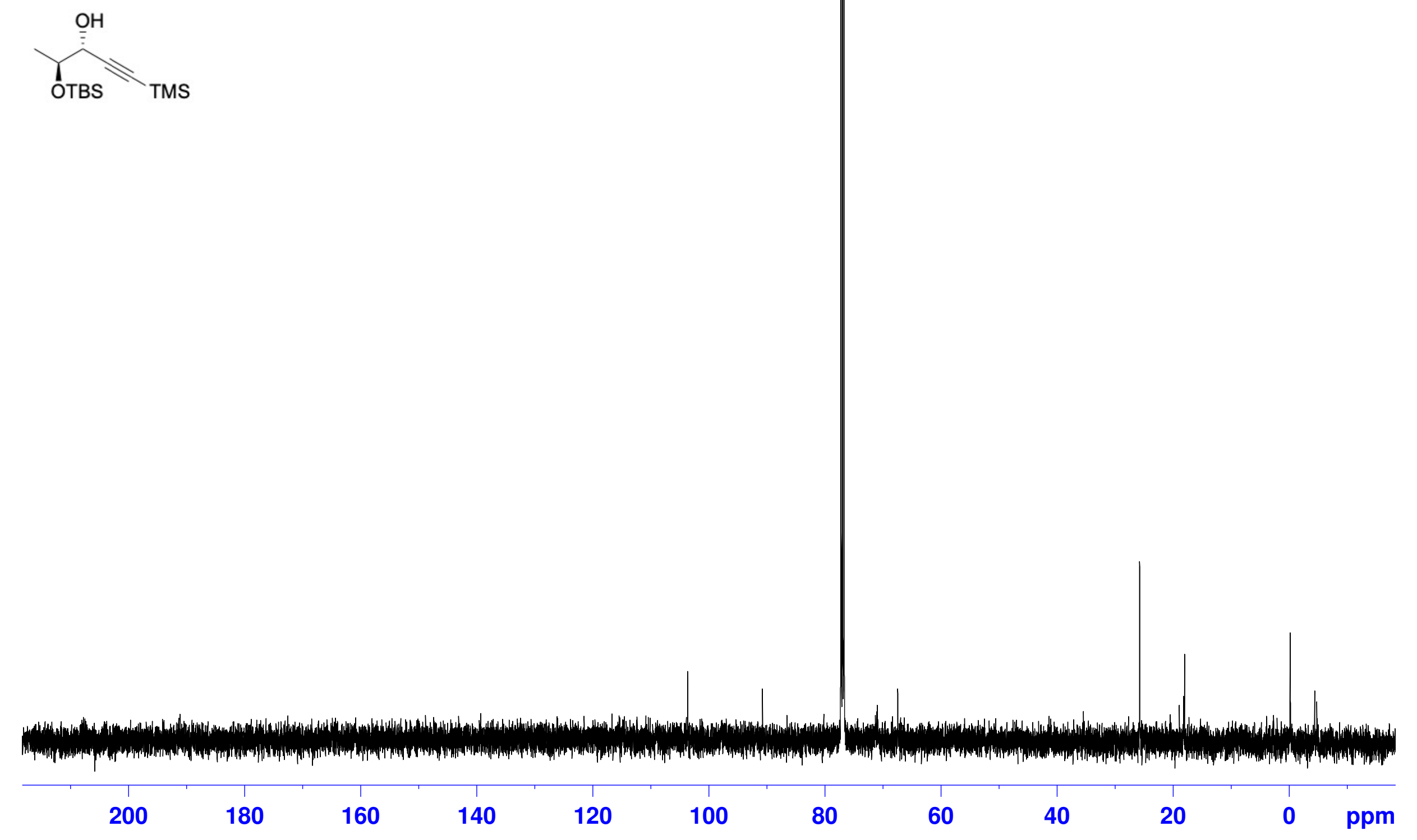
${ }^{1} \mathrm{H}$ NMR of $(+)-16\left(500 \mathrm{MHz}, \mathrm{CDCl}_{3}\right)$

6 m ON m $m$ m

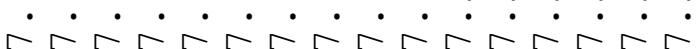

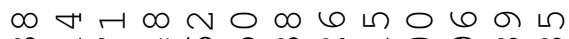
$\infty$ 그 $\dot{\gamma} \dot{\gamma} \dot{\gamma} \dot{m} \dot{m} \dot{m} \dot{m} \dot{m} \dot{m} \dot{m} \dot{m}$ $1<1$

$r m$

$\underset{\forall}{\psi}$

$\dot{\sim} \dot{\sim}$

$ヘ$

मㄷ

V

の $m$

00

.

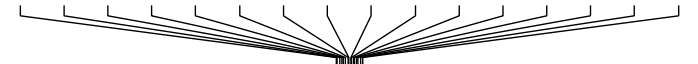

OBn
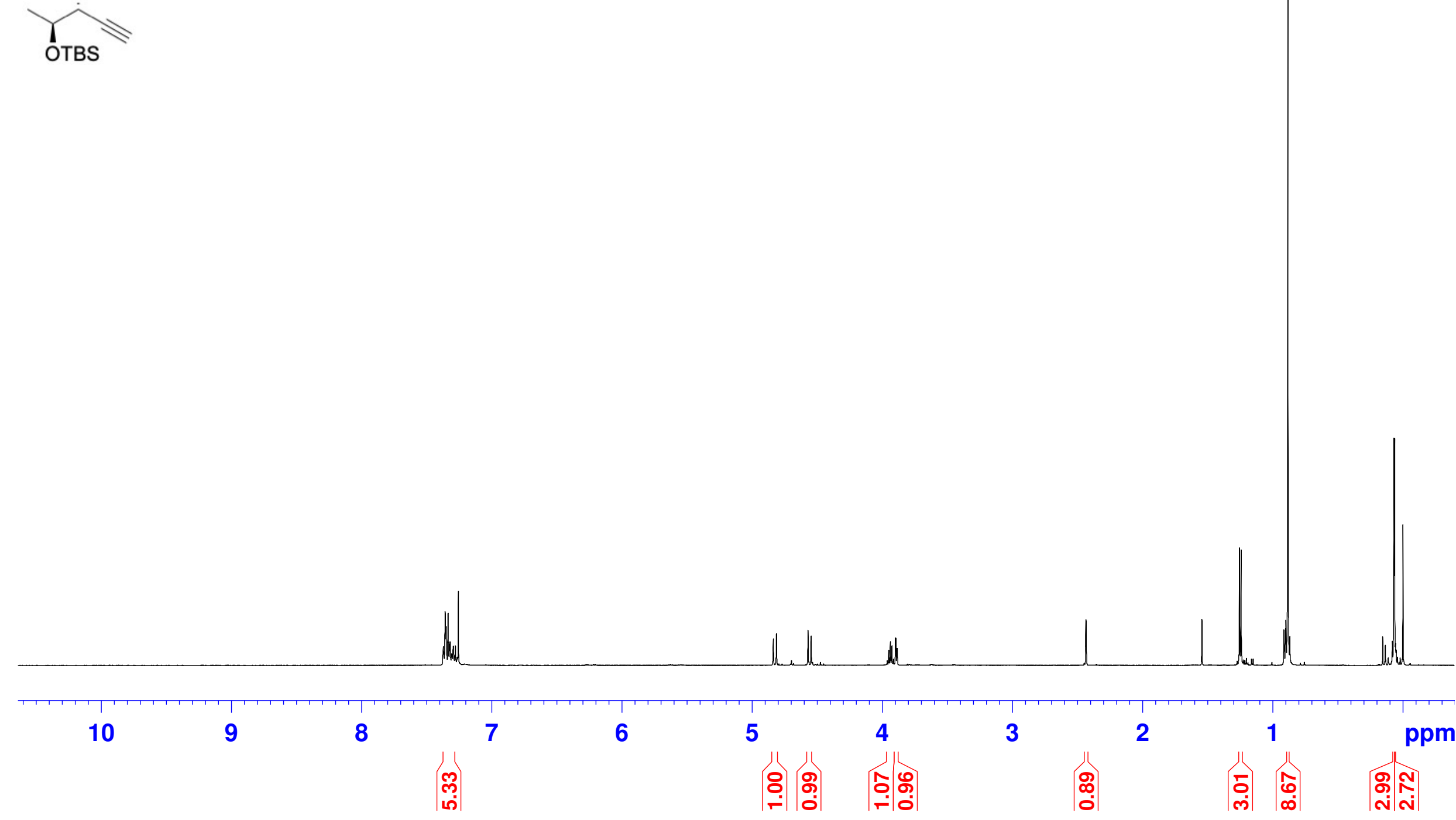
${ }^{13} \mathrm{C}$ NMR of $(+)-16\left(125 \mathrm{MHz}^{\left(+\mathrm{CDCl}_{3}\right)}\right.$

OBn
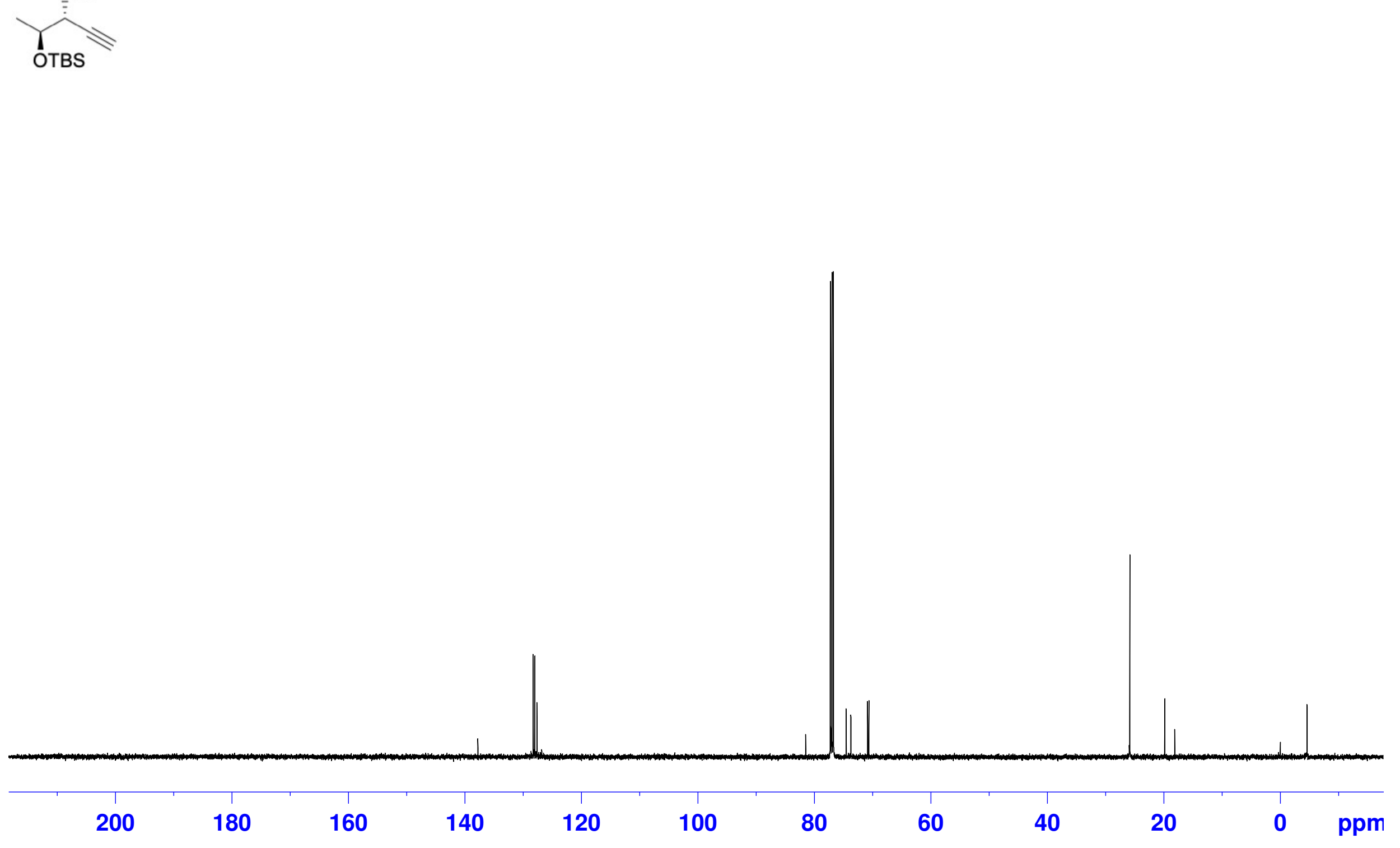
${ }^{1} \mathrm{H}$ NMR of $(+)-17\left(500 \mathrm{MHz}, \mathrm{CDCl}_{3}\right)$

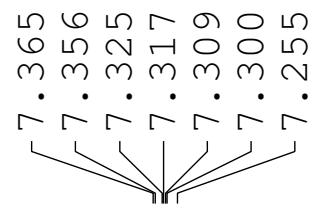

당ำ

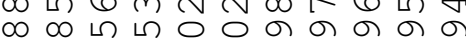

$\dot{\nabla} \dot{\nabla} \dot{\nabla} \dot{\nabla} \dot{r} \dot{m} \dot{m} \dot{m} \dot{m}$

ด $1 \mathrm{~mm}$ m $m \circ \sigma$

ก

$\dot{\sim} \dot{\sim} \dot{\sim}$

\section{OBn}<smiles>C#C[CH]C(C)O</smiles>

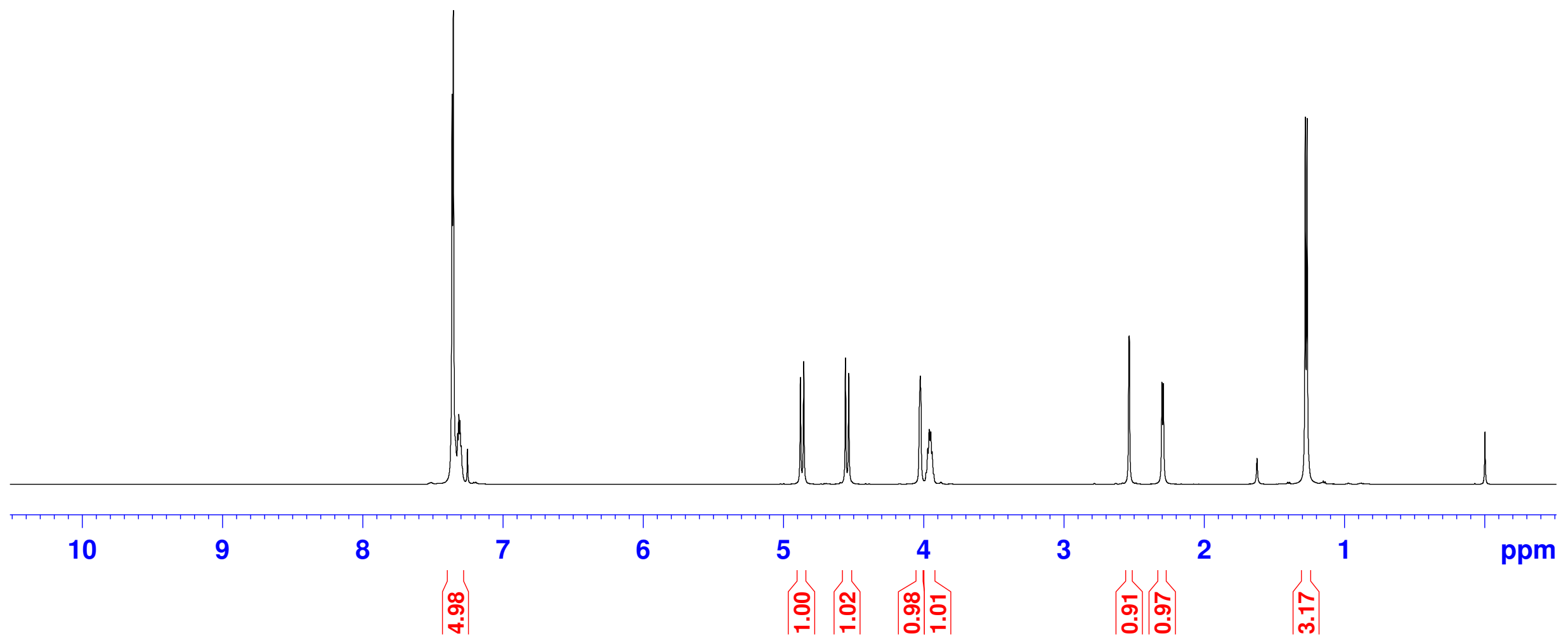


${ }^{13} \mathrm{C}$ NMR of $(+)-17\left(125 \mathrm{MHz}, \mathrm{CDCl}_{3}\right)$
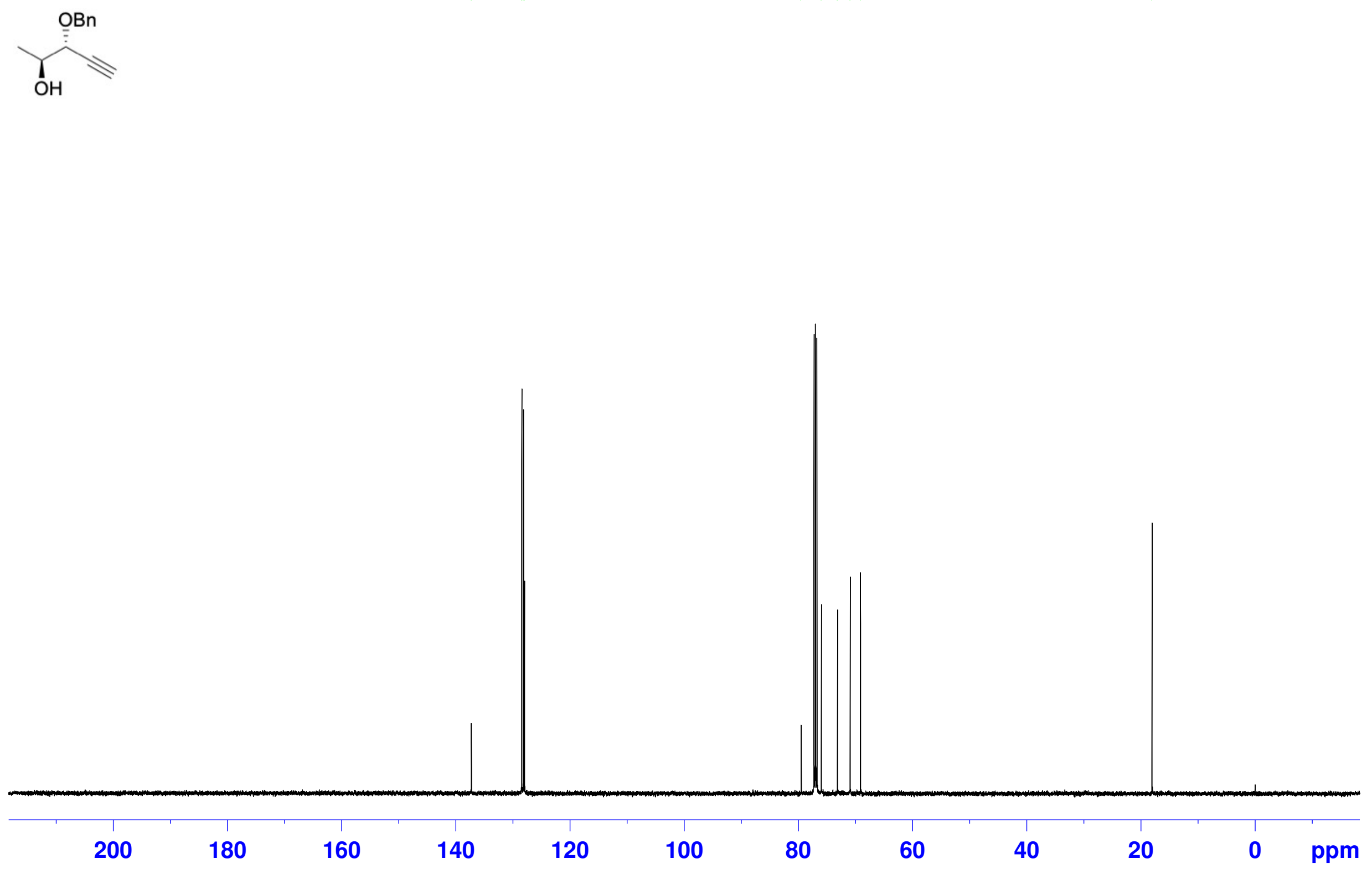
${ }^{1} \mathrm{H}$ NMR of (+)-18 (500 $\left.\mathrm{MHz}, \mathrm{CDCl}_{3}\right)$
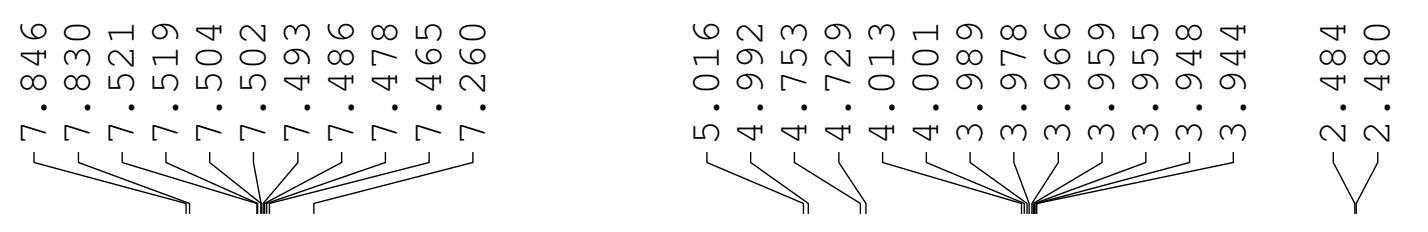

mi

คㅇํ

$\sim \sim 0$

- $\cdot$

तi

00

n

V

$\circ \circ$

OTBS $_{\text {OTap }}^{\text {ONap }}$

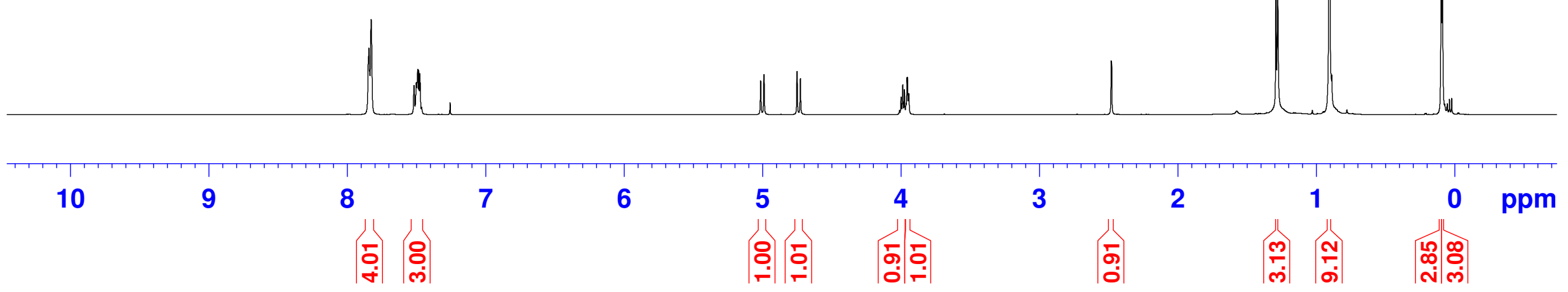


${ }^{13} \mathrm{C}$ NMR of $(+)-18\left(125 \mathrm{MHz}, \mathrm{CDCl}_{3}\right)$
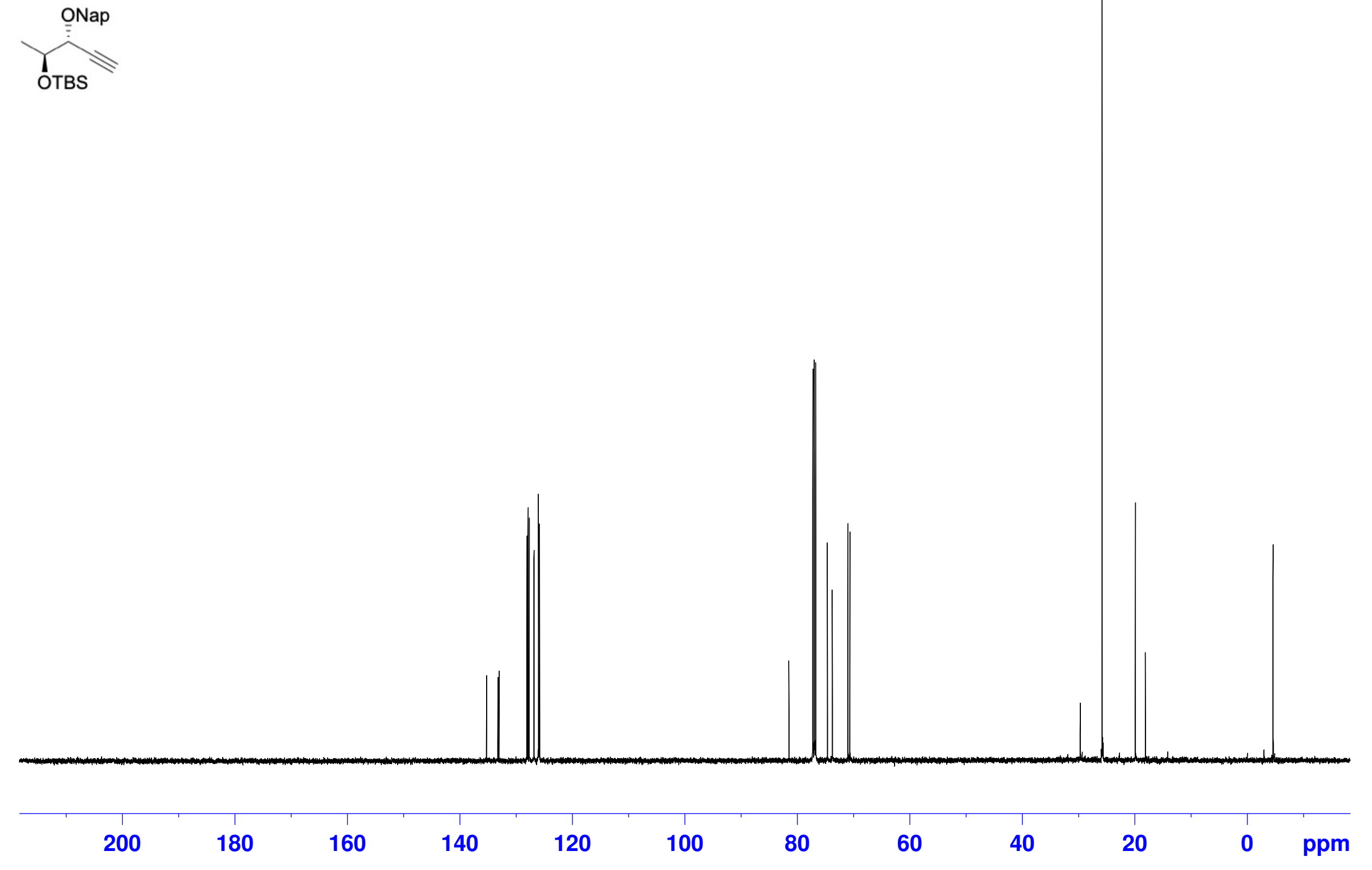
${ }^{1} \mathrm{H}$ NMR of (+)-19 (500 $\left.\mathrm{MHz}, \mathrm{CDCl}_{3}\right)$
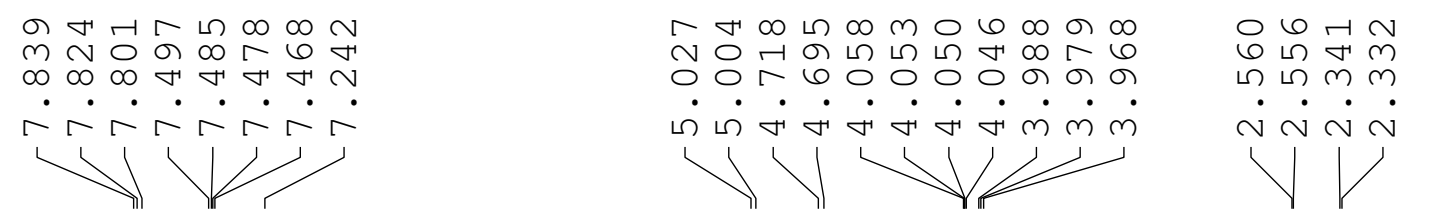

$\sim 0$

$\sim \sim$

.

가
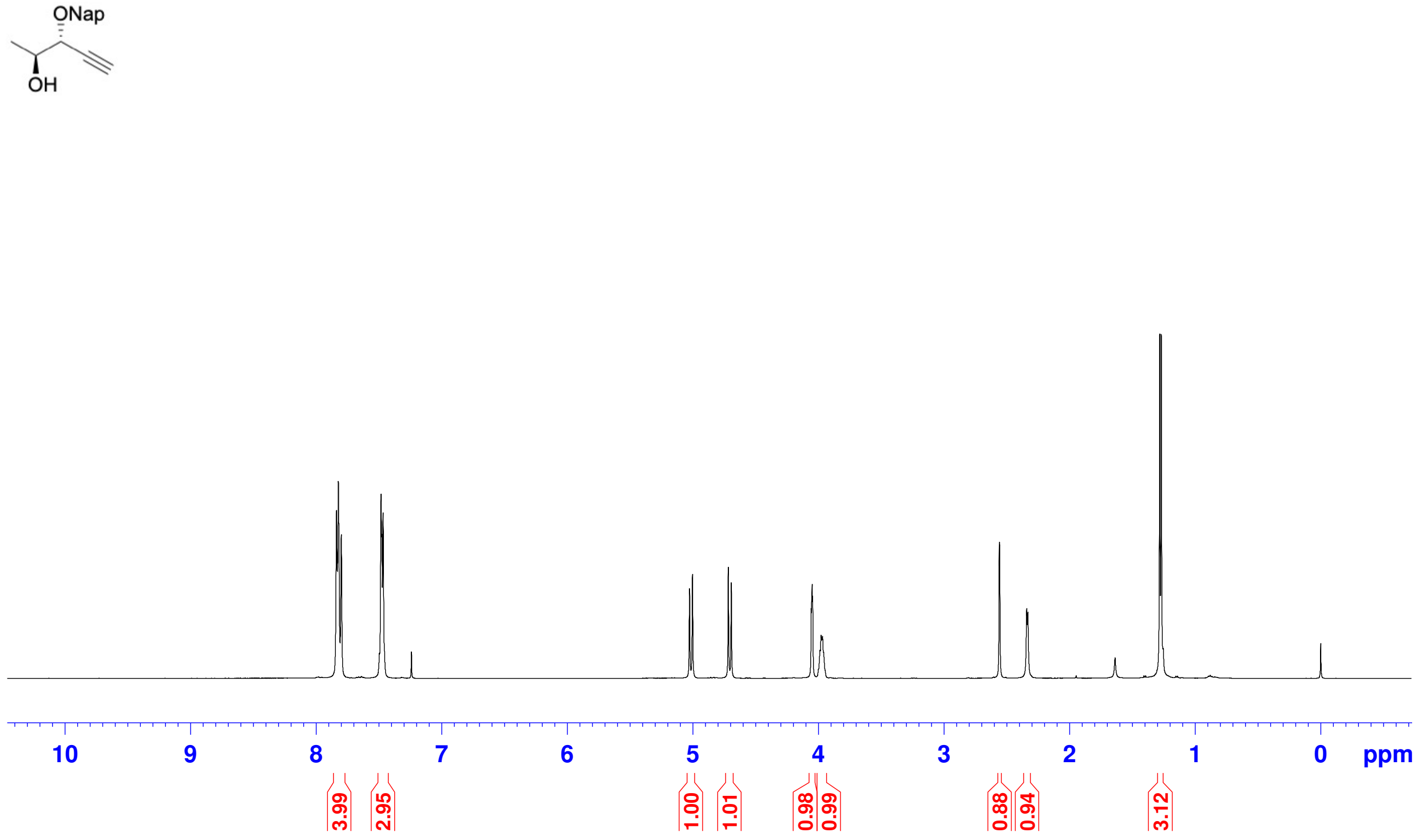
${ }^{13} \mathrm{C}$ NMR of (+)-19 (125 $\left.\mathrm{MHz}, \mathrm{CDCl}_{3}\right)$
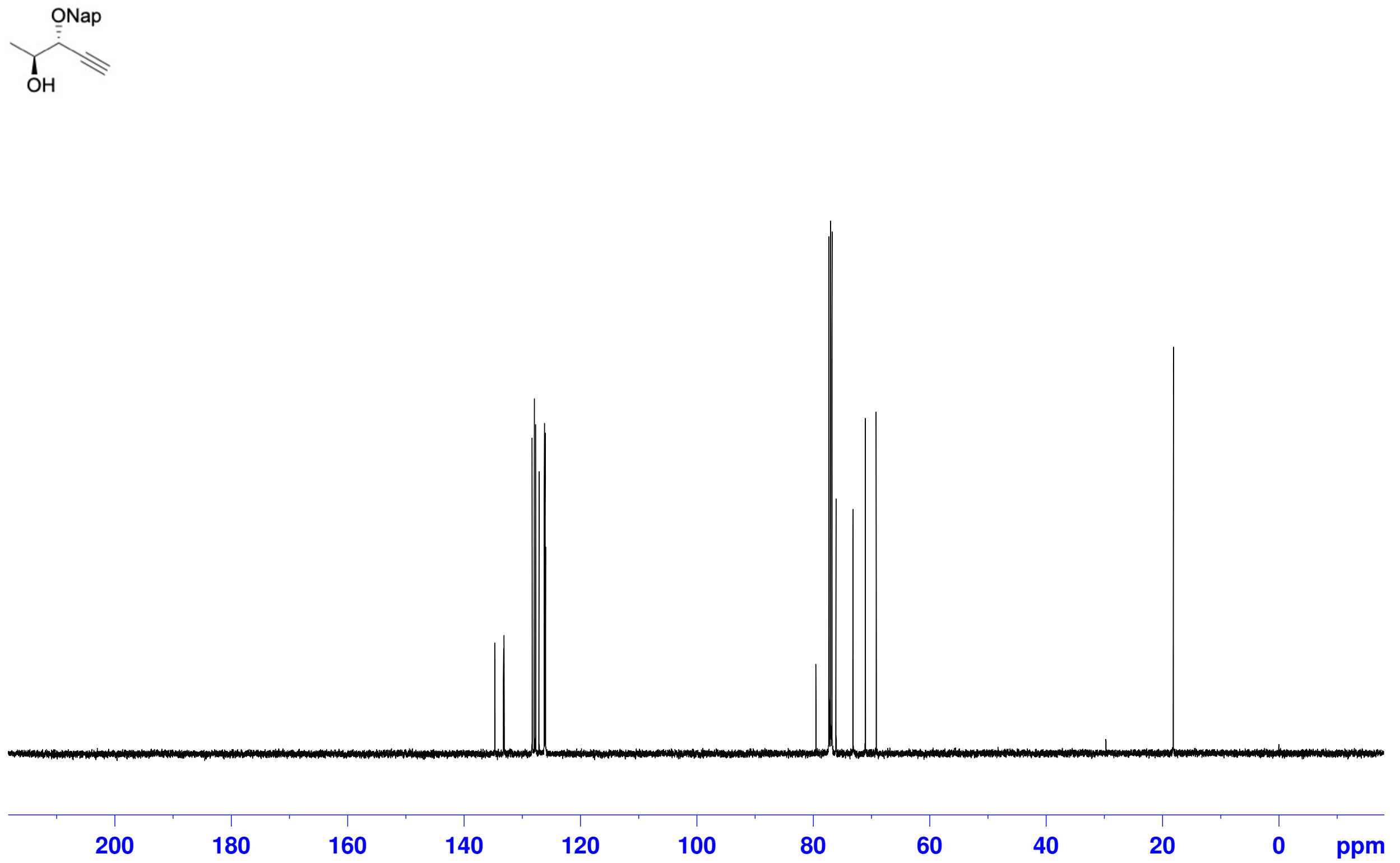
${ }^{1} \mathrm{H}$ NMR of $(+)-1\left(500 \mathrm{MHz}, \mathrm{C}_{6} \mathrm{D}_{6}\right)$

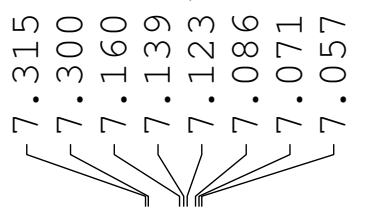

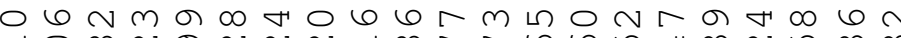

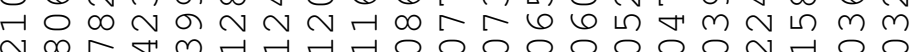

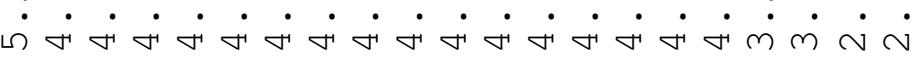

の 6

m.

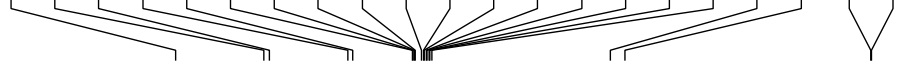<smiles>C#CC(Cc1ccccc1)C(C)OC(OC)OC</smiles>

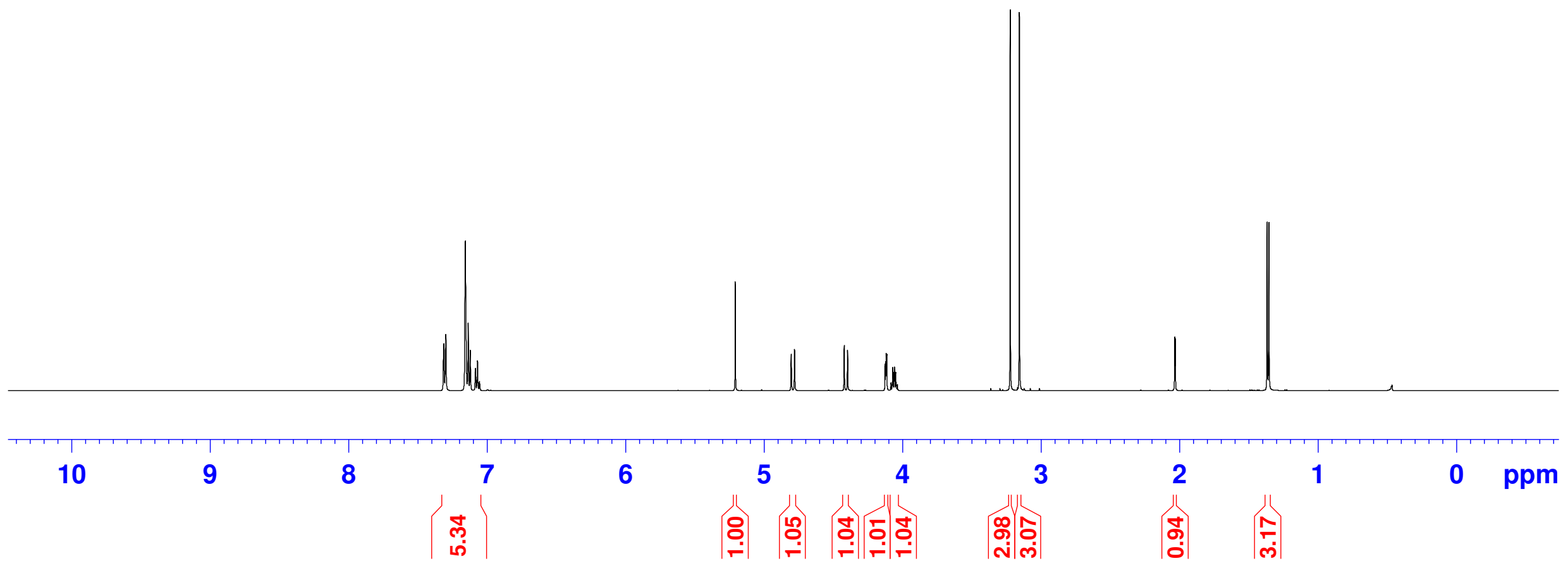


${ }^{13} \mathrm{C}$ NMR of (t)-1 (125 $\left.\mathrm{MHz}, \mathrm{C}_{6} \mathrm{D}_{6}\right)$
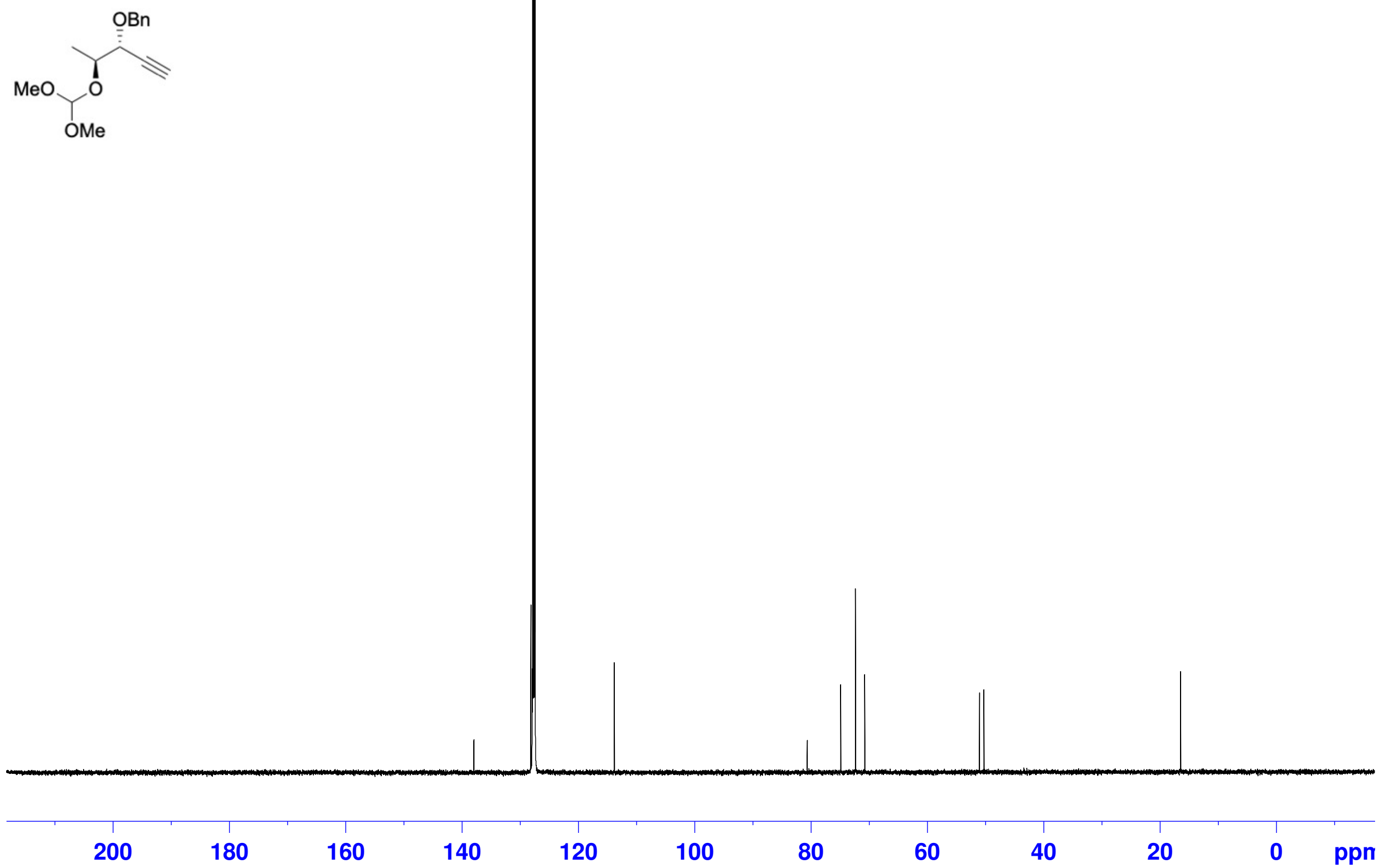
${ }^{1} \mathrm{H}$ NMR of $(+)-2\left(500 \mathrm{MHz}, \mathrm{C}_{6} \mathrm{D}_{6}\right)$

மூ

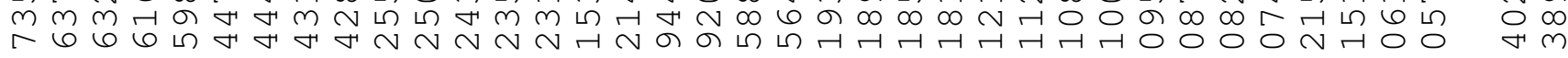

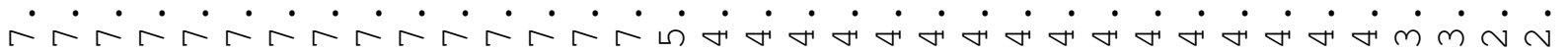
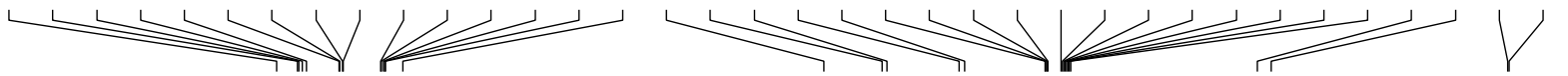<smiles>C#CC(O[N+](=O)[O-])C(C)OC(OC)OC</smiles>

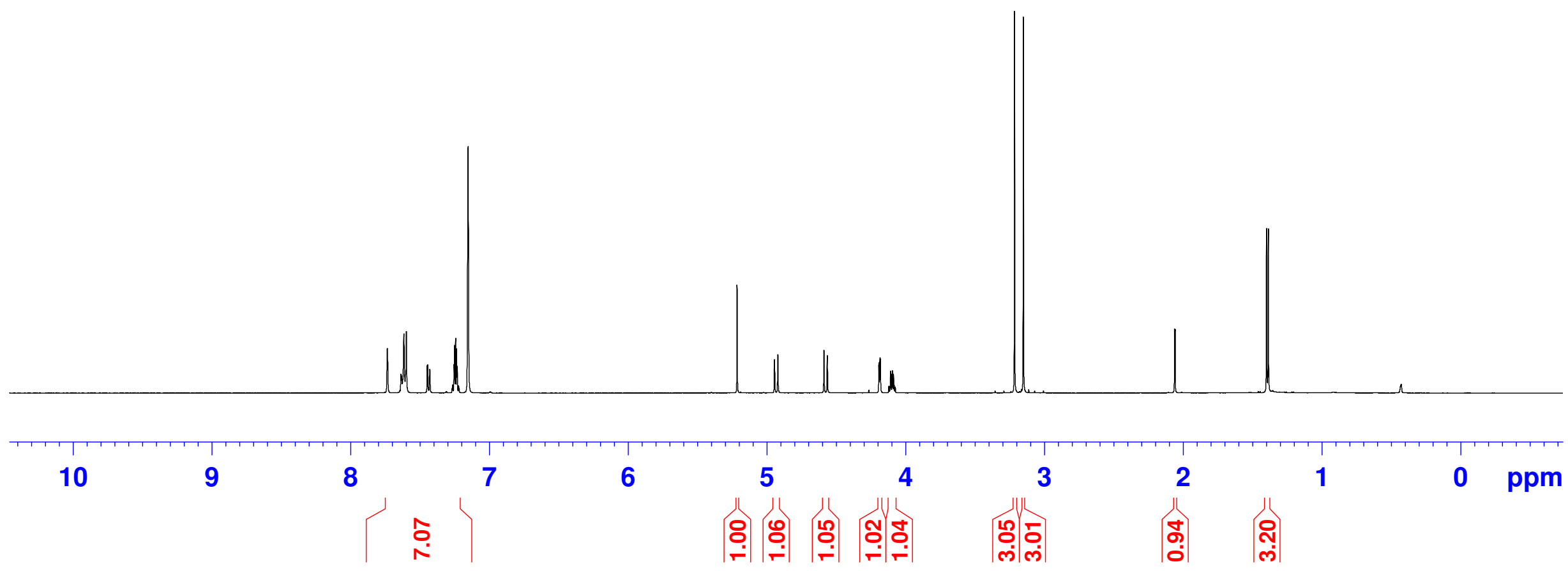


${ }^{13} \mathrm{C}$ NMR of $(+)-2\left(125 \mathrm{MHz}, \mathrm{C}_{6} \mathrm{D}_{6}\right)$
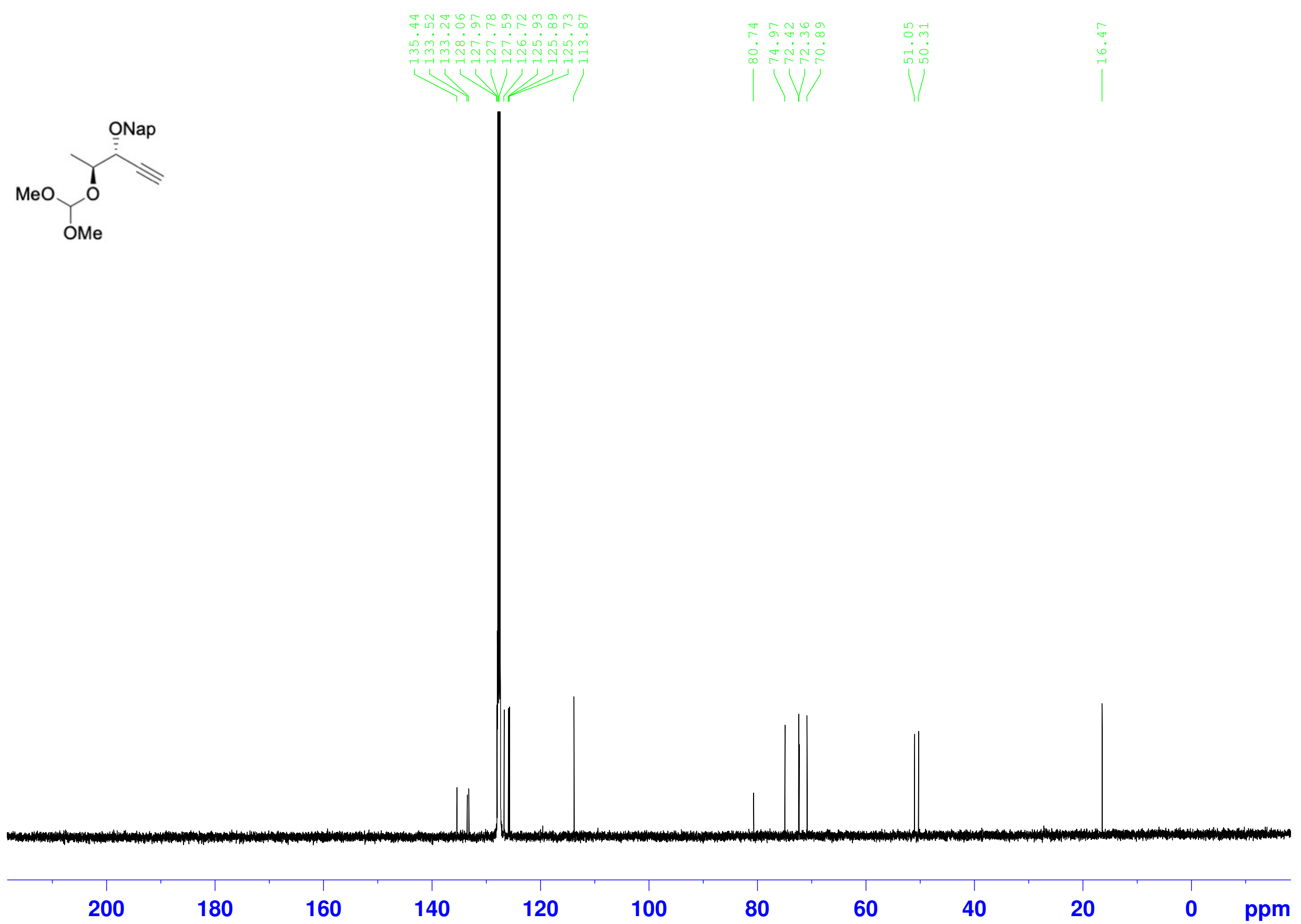
${ }^{13} \mathrm{C}$ NMR of (-)-20 (500 $\left.\mathrm{MHz}, \mathrm{CDCl}_{3}\right)$

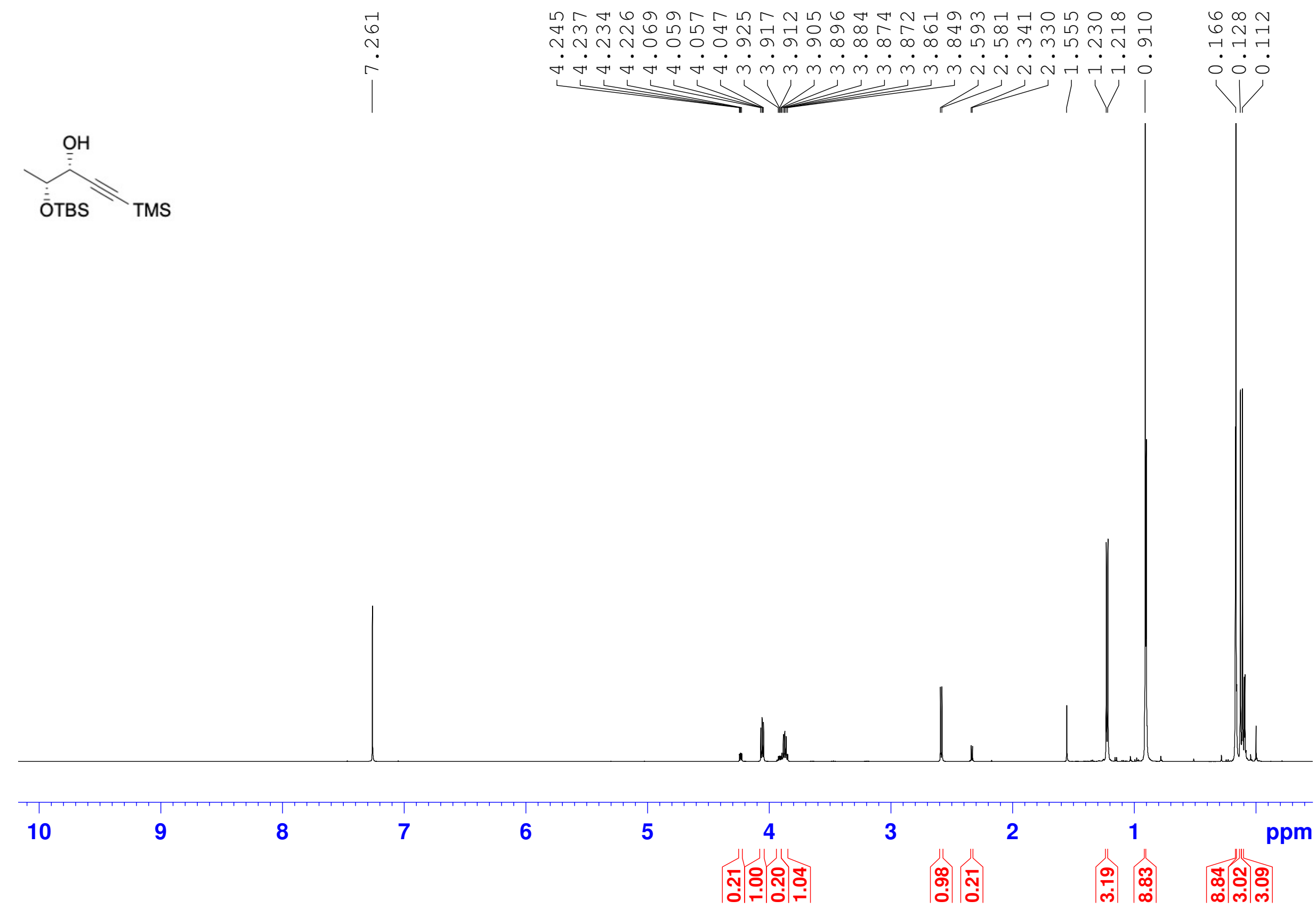


${ }^{13} \mathbf{C}$ NMR of (-)-20 (125 $\left.\mathrm{MHz}, \mathrm{CDCl}_{3}\right)$
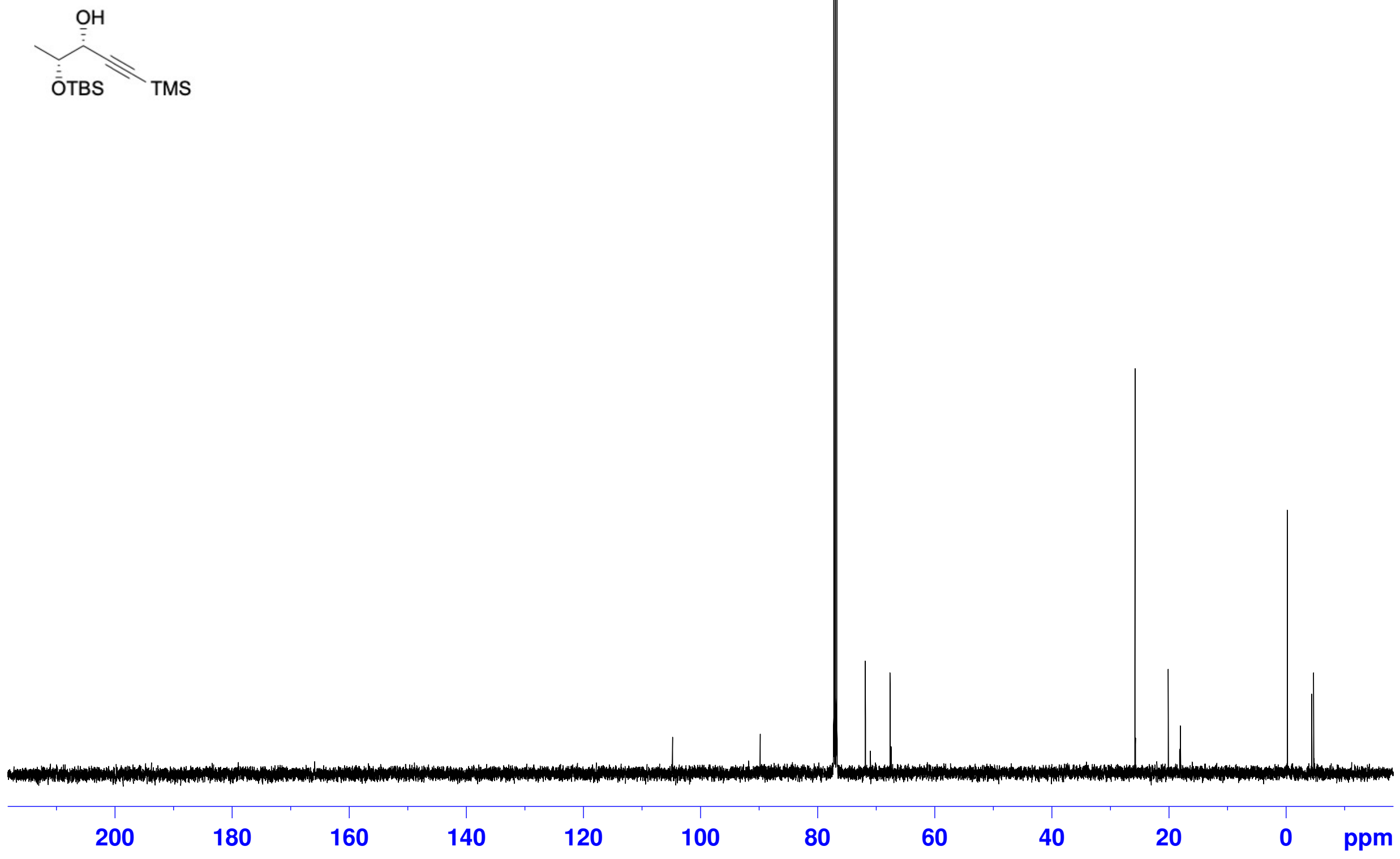
${ }^{1} \mathrm{H}$ NMR of (-)-21 (500 $\left.\mathrm{MHz}, \mathrm{CDCl}_{3}\right)$

$\sim 6 \infty \circ+1$

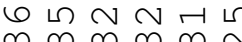

.

の

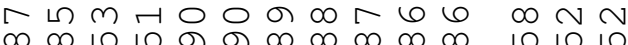

$\infty, \infty$

$\forall \forall+\Rightarrow m m m m m m \sim \dot{N}$

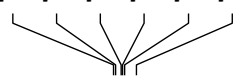

11

$\mathrm{OBn}$<smiles>CCC(C)O</smiles>

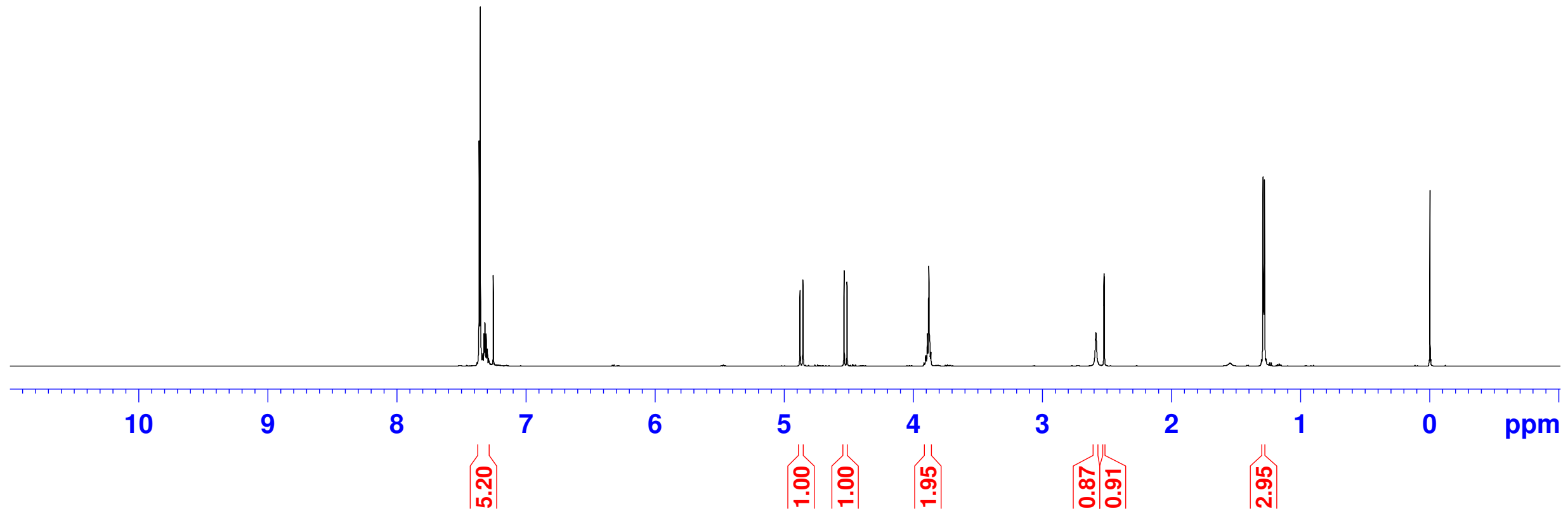


${ }^{13} \mathrm{C}$ NMR of (-)-21 (125 $\left.\mathrm{MHz}, \mathrm{CDCl}_{3}\right)$
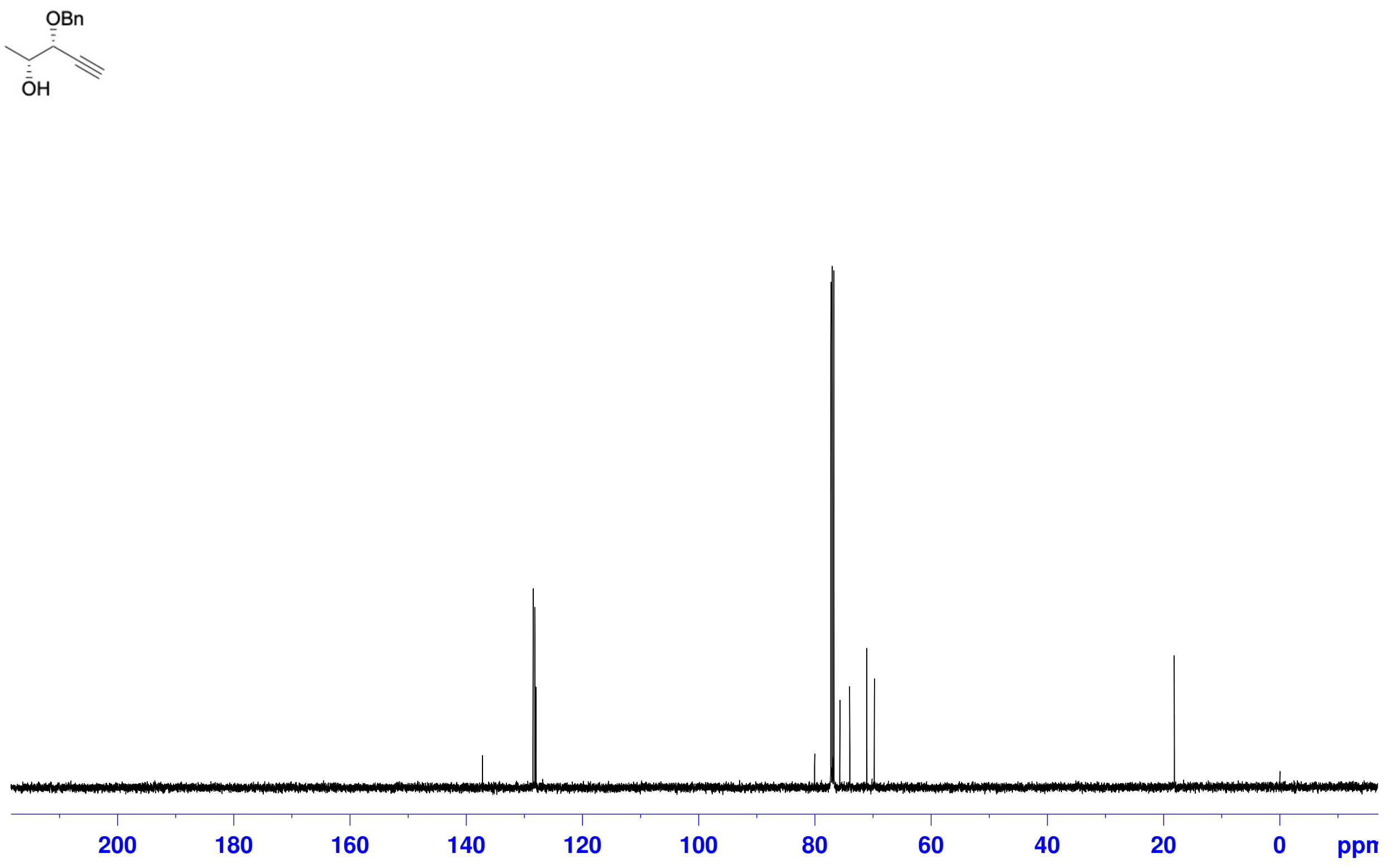
${ }^{1} \mathrm{H}$ NMR of (-)-3 (500 $\left.\mathrm{MHz}, \mathrm{C}_{6} \mathrm{D}_{6}\right)$

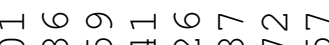

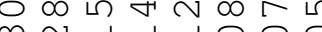
. . . . . . . harharh
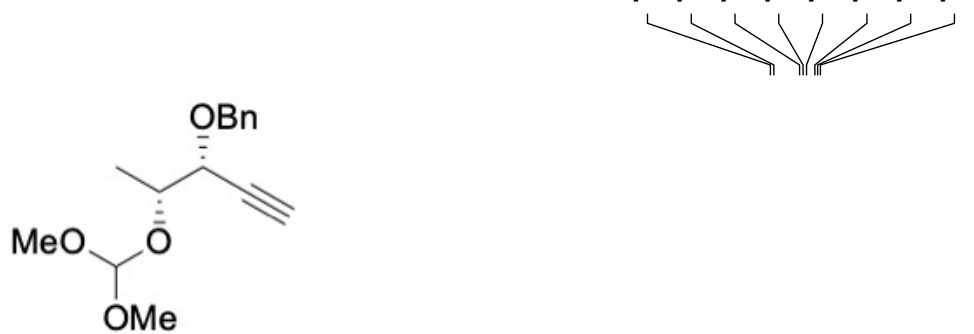

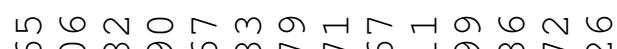
$6 \circ \infty 6 \infty \pi-6+\pi \infty \pi$ , m m

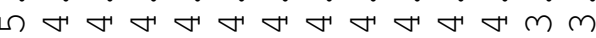

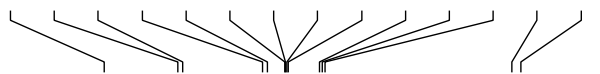

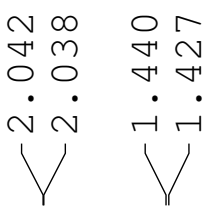

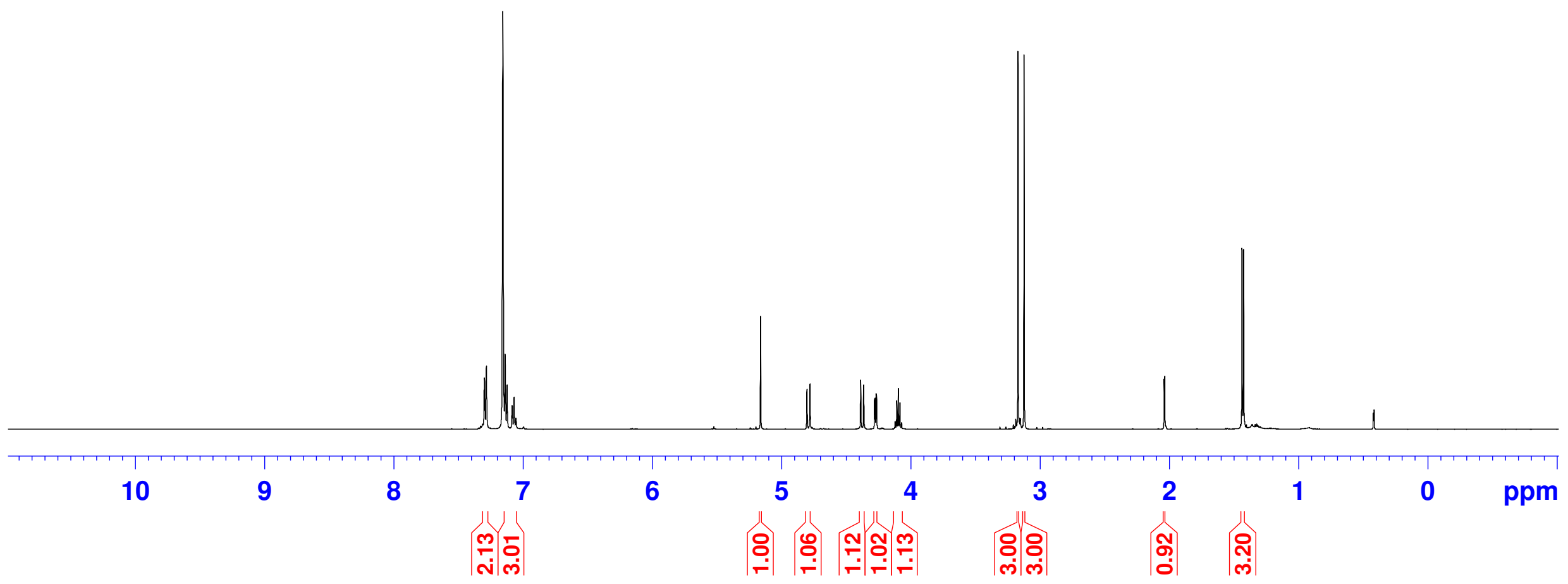


${ }^{13} \mathrm{C}$ NMR of (-)-3 (125 $\left.\mathrm{MHz}, \mathrm{C}_{6} \mathrm{D}_{6}\right)$

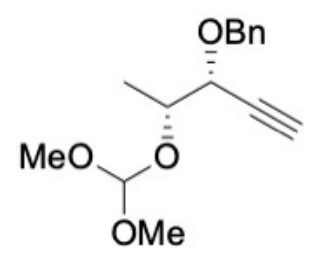

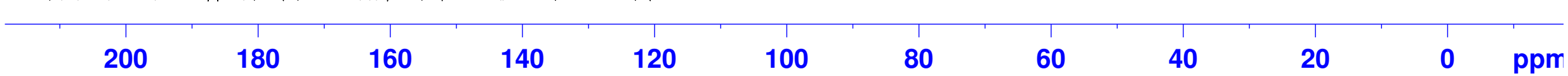


${ }^{1} \mathrm{H}$ NMR of (+)-20 (500 MHz, $\left.\mathrm{CDCl}_{3}\right)$<smiles>CC(C)O[Sb](C)(=O)=O</smiles>

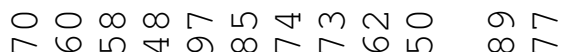

$$
\begin{aligned}
& \circ \circ 0 \bigcirc \infty \infty \infty \infty \infty \infty \text { ம } \\
& \text { i } \\
& \text { अभन } भ m m m m m \\
& \longrightarrow \\
& \dot{\sim} \dot{\sim}
\end{aligned}
$$

$\sim \sim \sigma$

호글
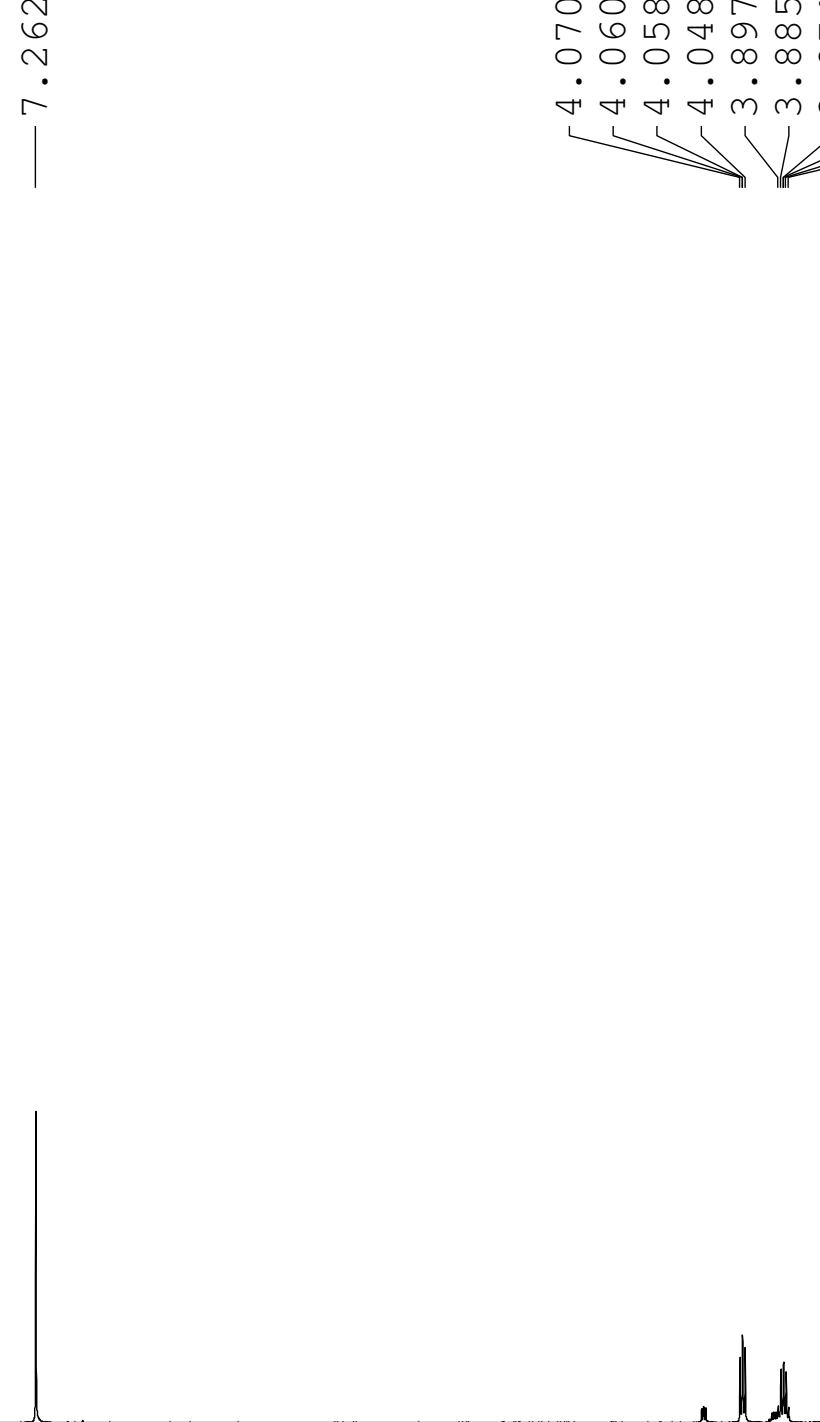

$6 \quad 5$

5 
${ }^{13} \mathrm{C}$ NMR of (+)-20 (125 $\left.\mathrm{MHz}, \mathrm{CDCl}_{3}\right)$
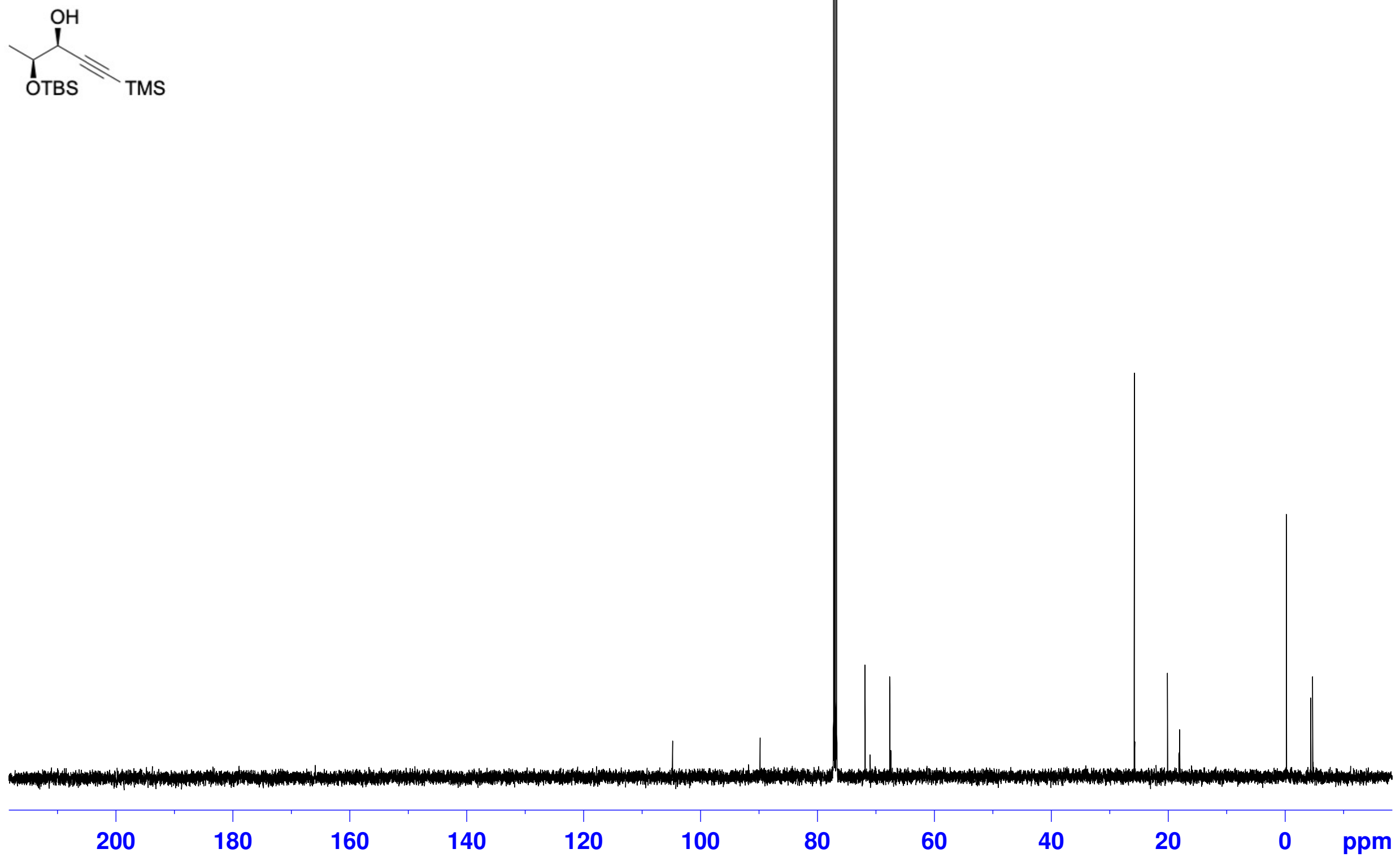
${ }^{1} \mathrm{H}$ NMR of (+)-21 (500 $\left.\mathrm{MHz}, \mathrm{CDCl}_{3}\right)$

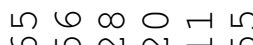

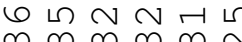

の

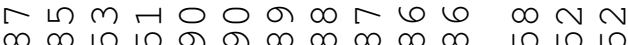

$\infty, \infty$

$\therefore r i r i r$

$\forall \forall+\% m m m m m m$

14

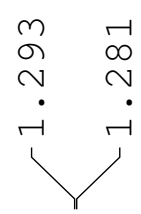

$\overbrace{\mathrm{OH}}^{\mathrm{OBn}}$

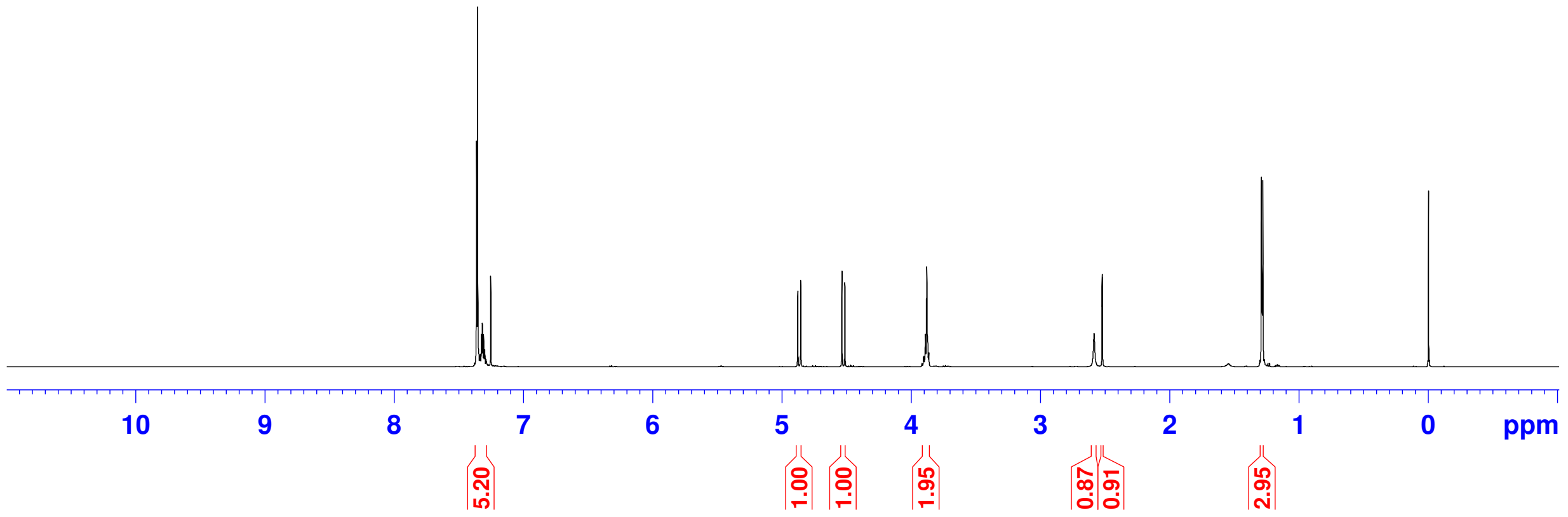


${ }^{13} \mathrm{C}$ NMR of $(+)-21\left(125 \mathrm{MHz}, \mathrm{CDCl}_{3}\right)$
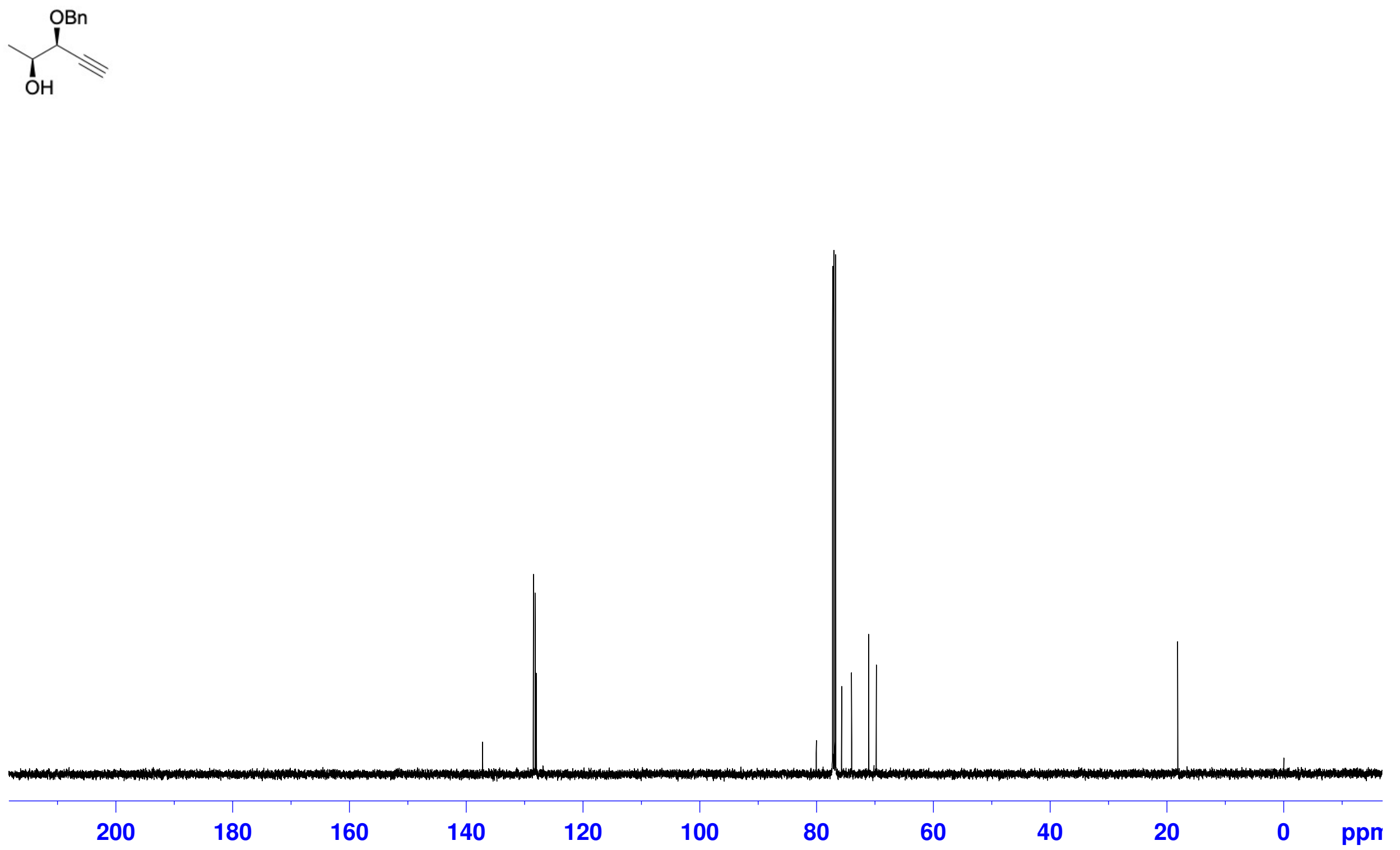
${ }^{1} \mathrm{H}$ NMR of $(+)-3\left(500 \mathrm{MHz}, \mathrm{C}_{6} \mathrm{D}_{6}\right)$
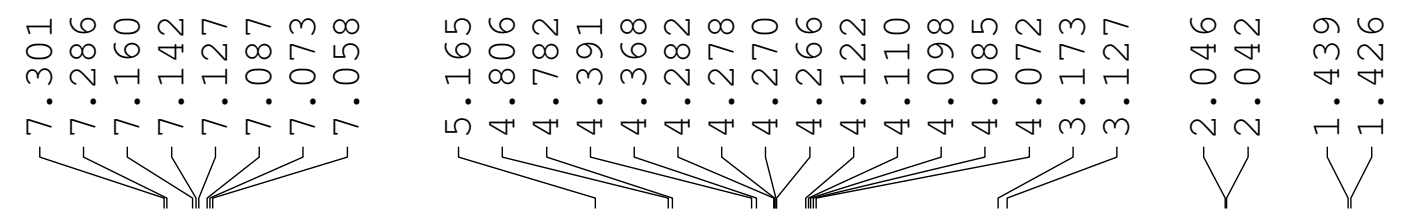

$\underbrace{\mathrm{OBn}}_{\text {OMe }}$

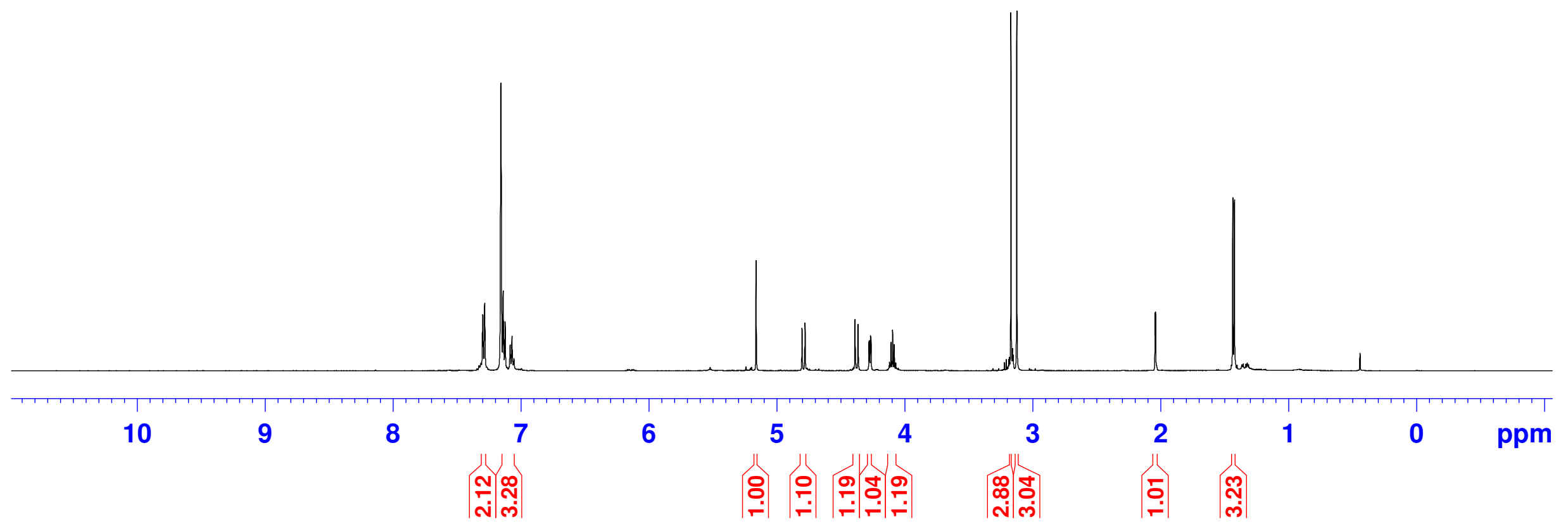


${ }^{13} \mathrm{C}$ NMR of $(+)-3\left(125 \mathrm{MHz}, \mathrm{C}_{6} \mathrm{D}_{6}\right)$
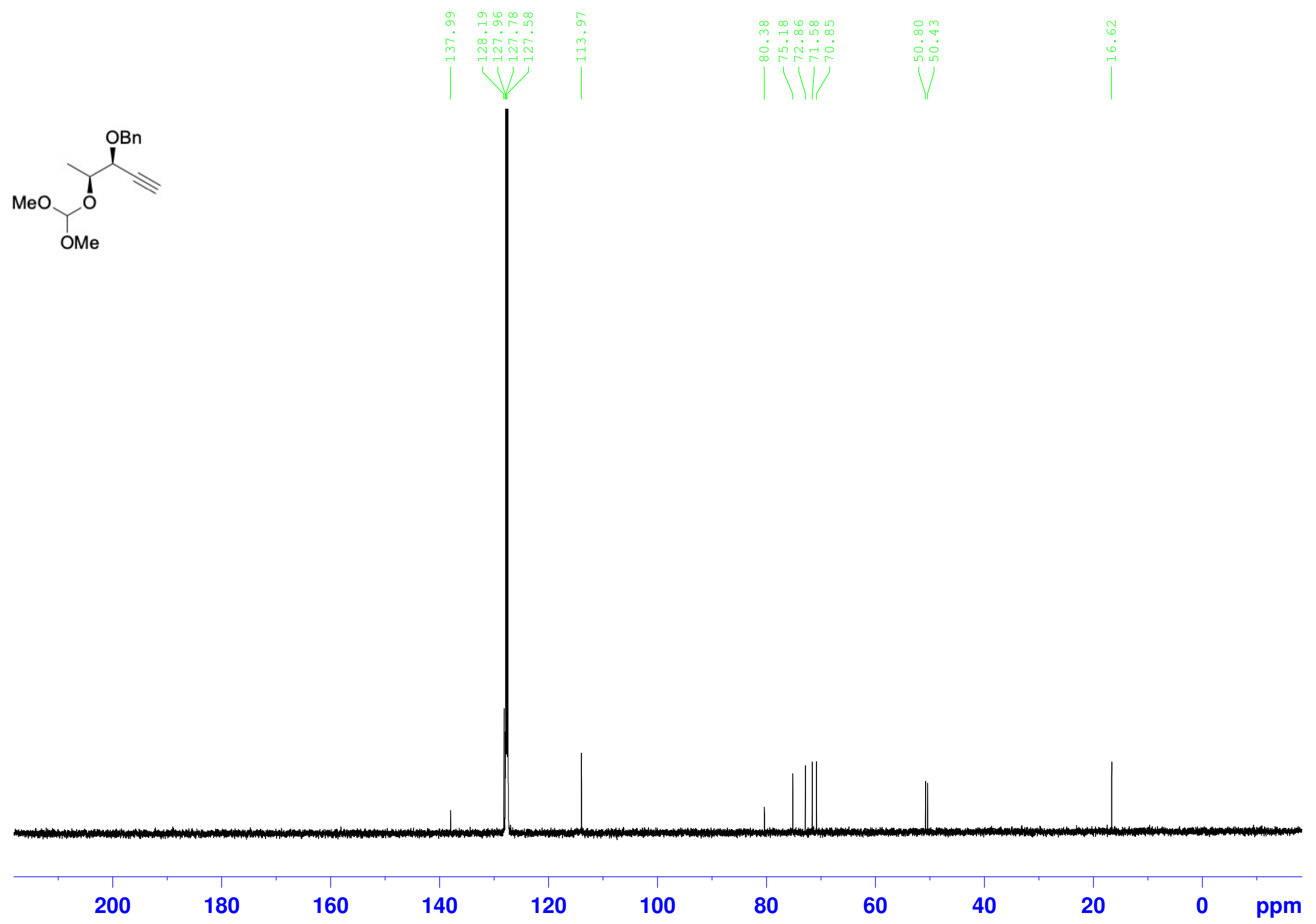
${ }^{1} \mathrm{H}$ NMR of $(+)-4\left(500 \mathrm{MHz}, \mathrm{C}_{6} \mathrm{D}_{6}\right)$

小

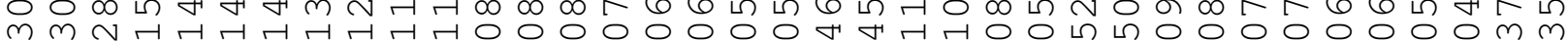

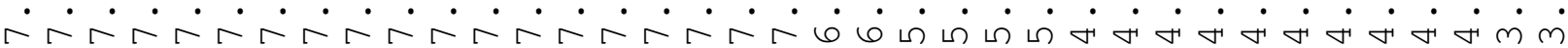<smiles></smiles>

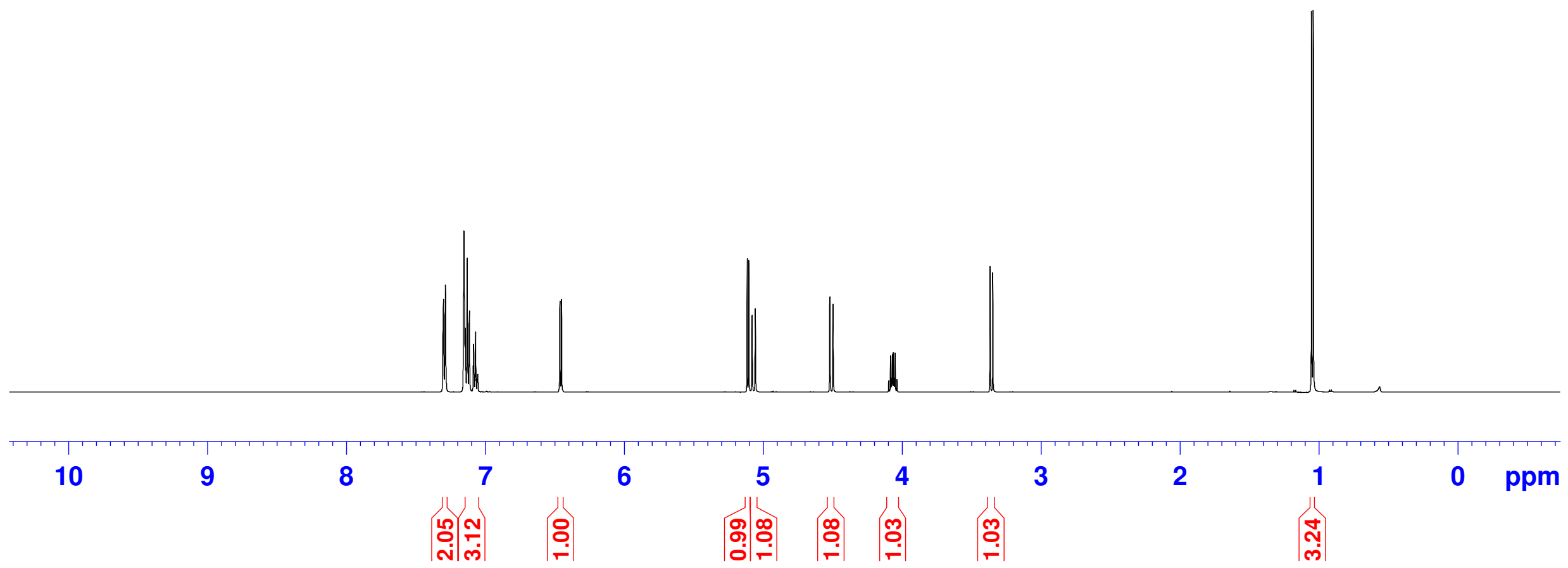


${ }^{13} \mathrm{C}$ NMR of $(+)-4 \quad\left(125 \mathrm{MHz}, \mathrm{C}_{6} \mathrm{D}_{6}\right)$
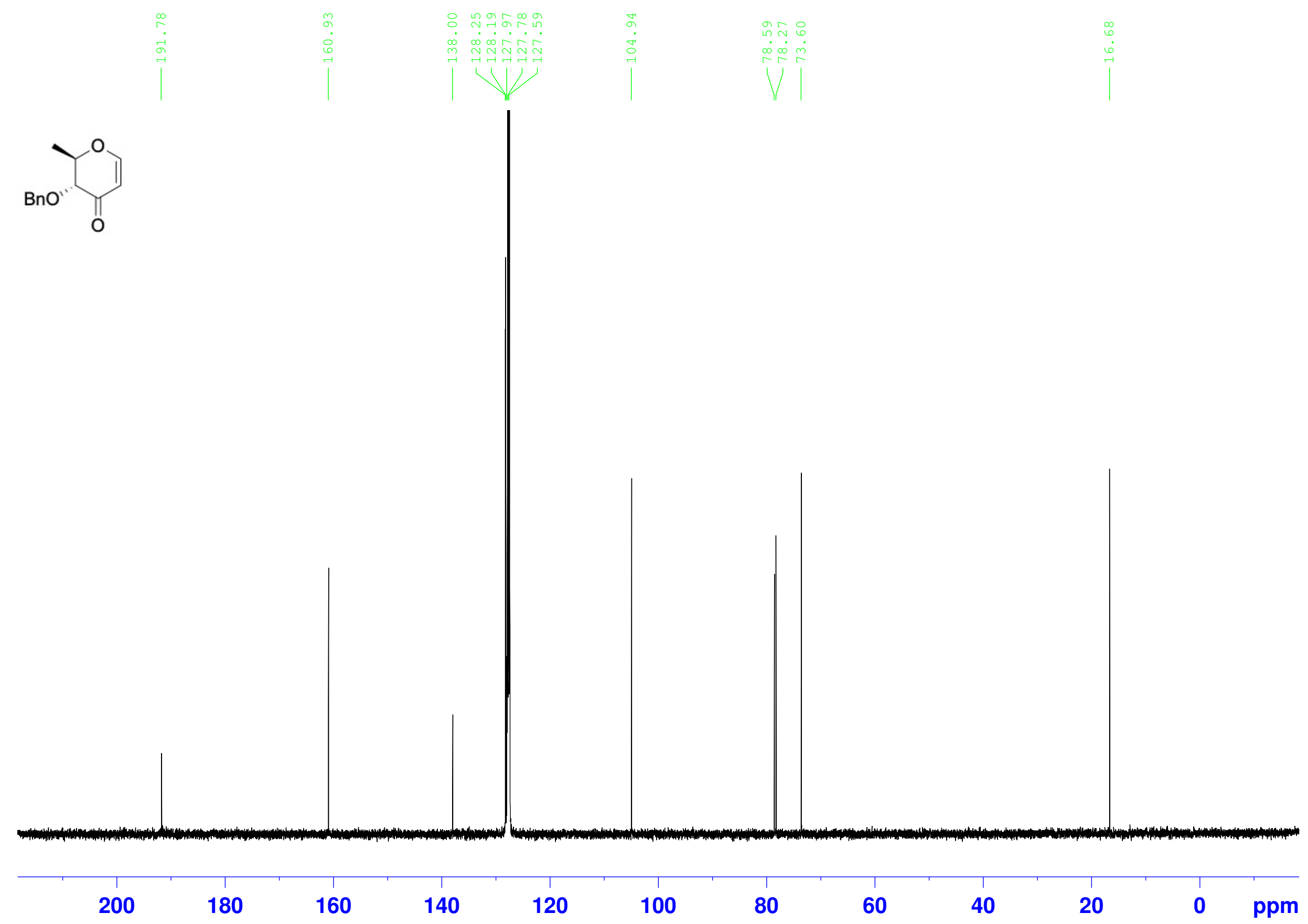
${ }^{1} \mathrm{H}$ NMR of (-) $-4 \quad\left(500 \mathrm{MHz}, \mathrm{C}_{6} \mathrm{D}_{6}\right)$

开 $m m N$ m $\mathrm{m}$ H H H

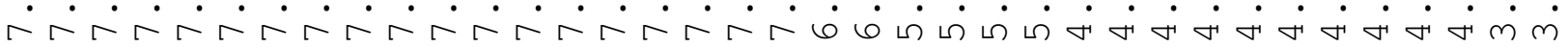<smiles>C[C@H]1OC=CC(=O)[C@H]1OCc1ccccc1</smiles>

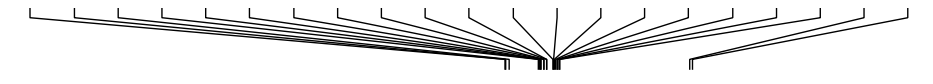

Ve K

$6 \mathrm{~m}$

○)

.

다

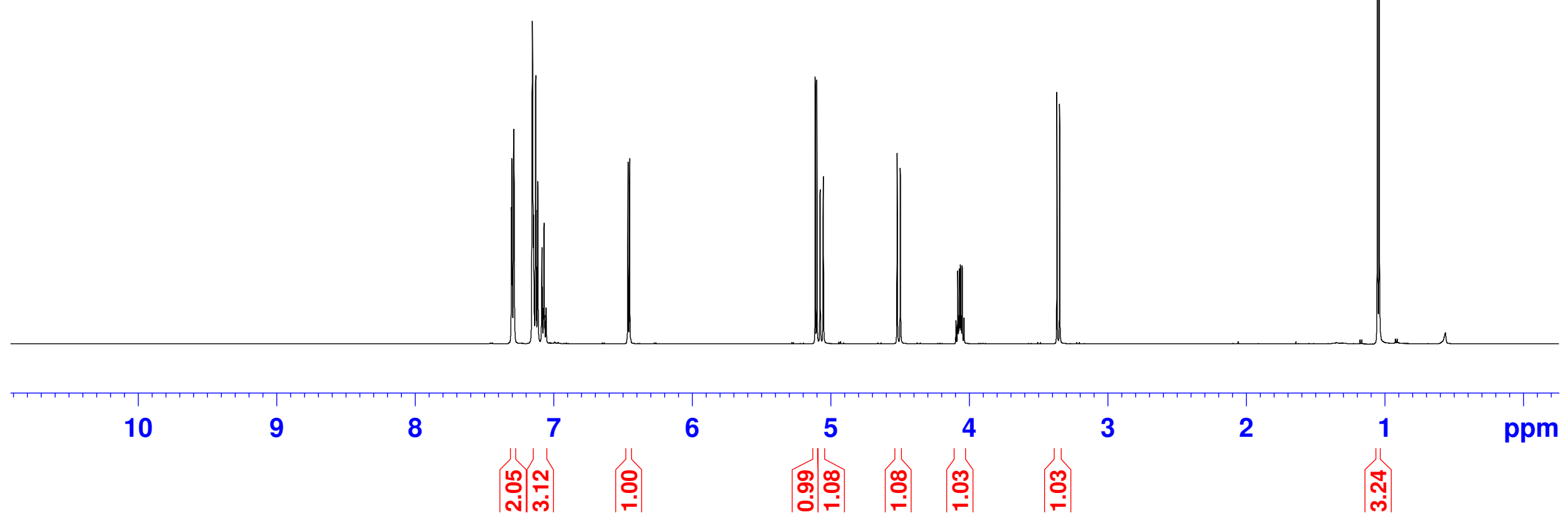


${ }^{13} \mathrm{C}$ NMR of $(-)-4\left(125 \mathrm{MHz}, \mathrm{C}_{6} \mathrm{D}_{6}\right)$
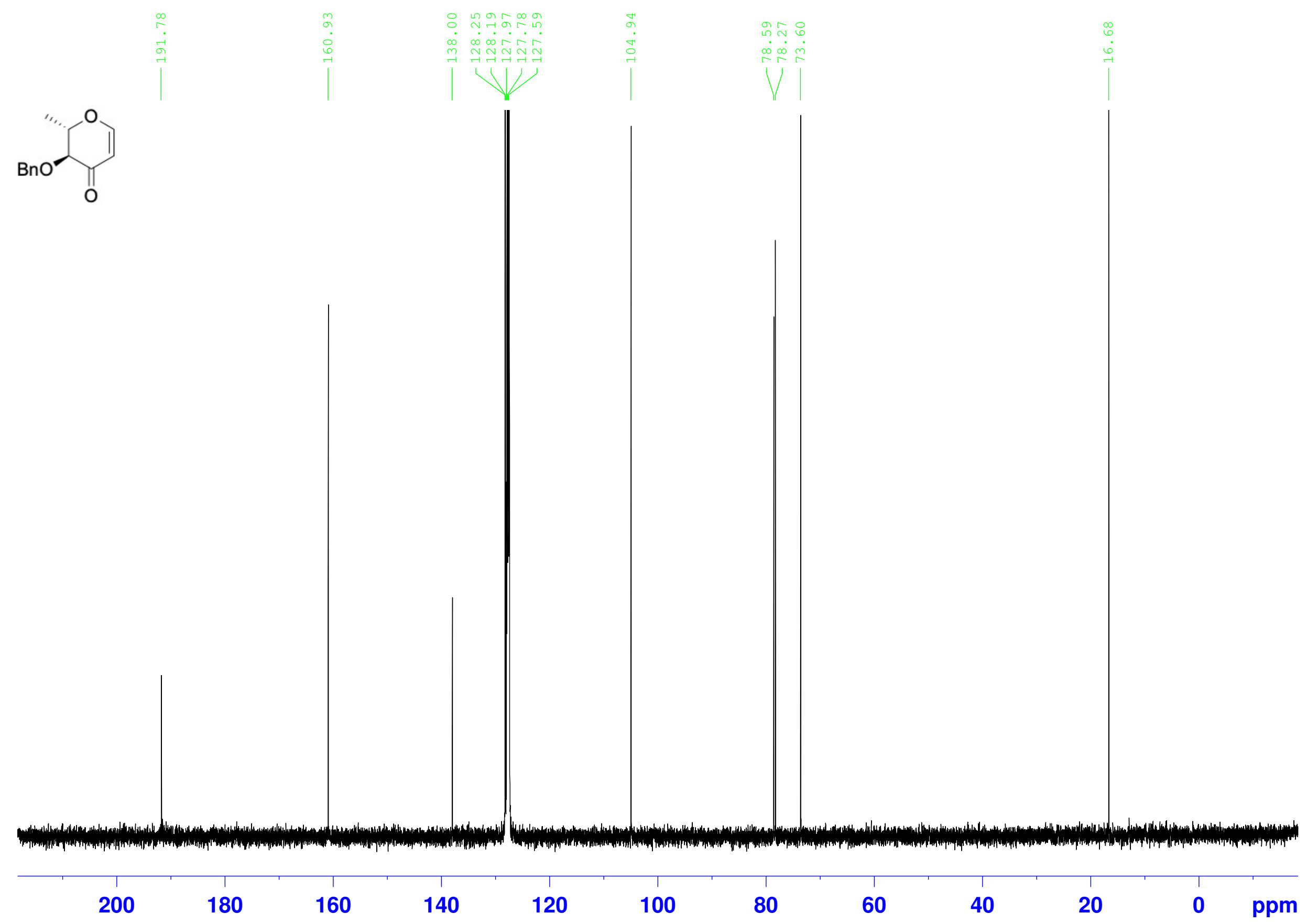
${ }^{1} \mathrm{H}$ NMR of (-)-5 (500 MHz, $\left.\mathrm{CDCl}_{3}\right)$
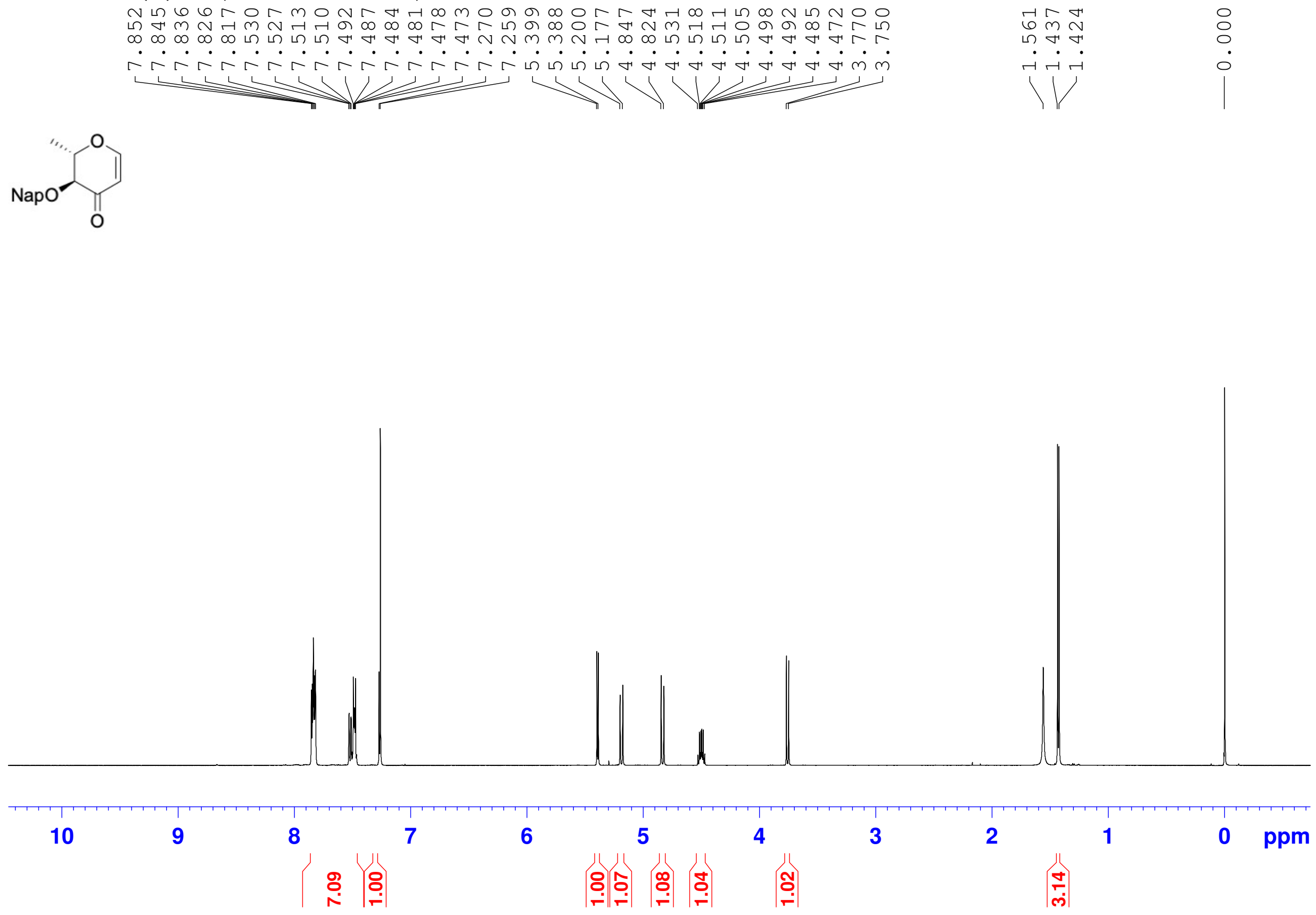
${ }^{13} \mathrm{C}$ NMR of (-)-5 (125 $\left.\mathrm{MHz}, \mathrm{CDCl}_{3}\right)$
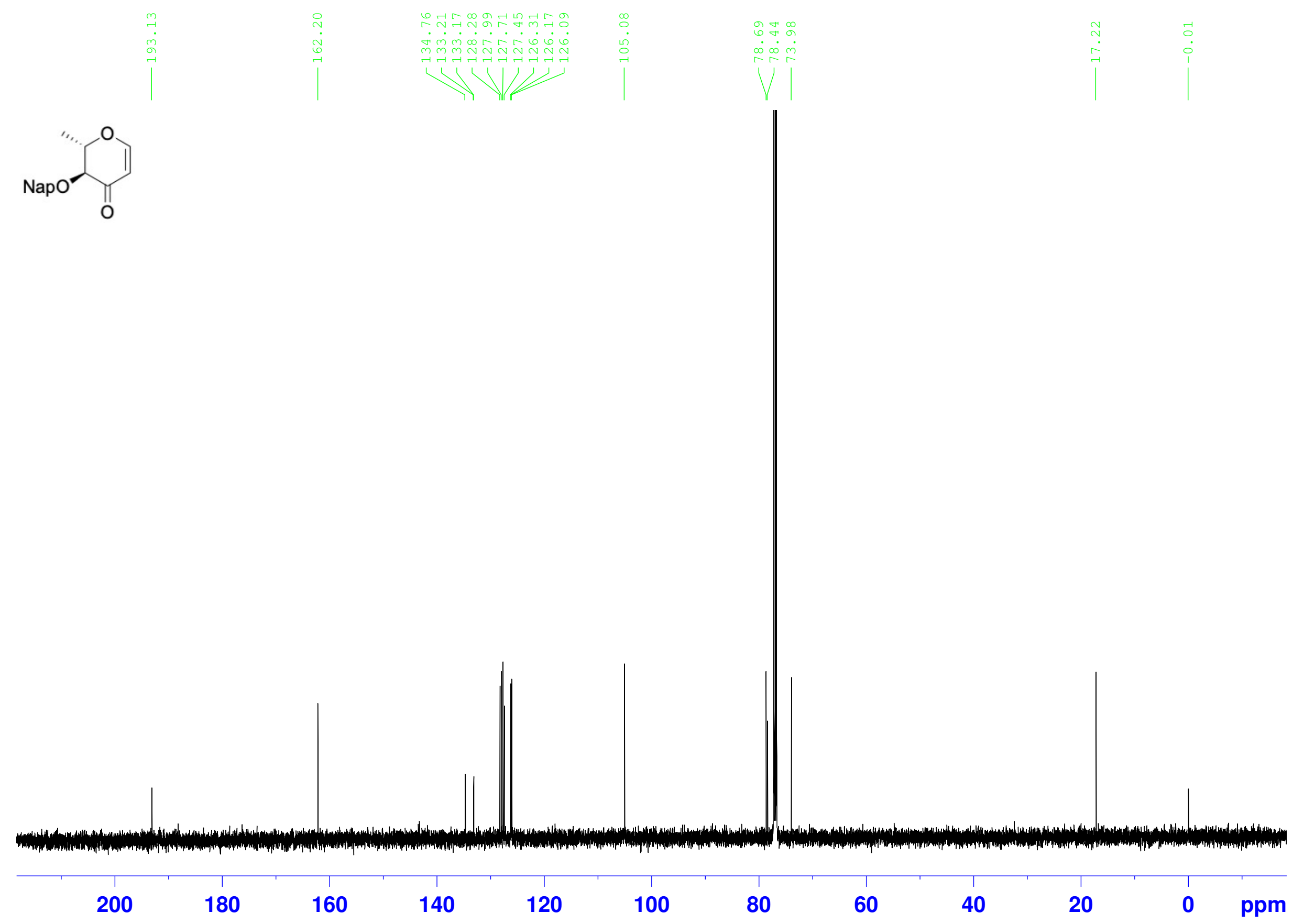


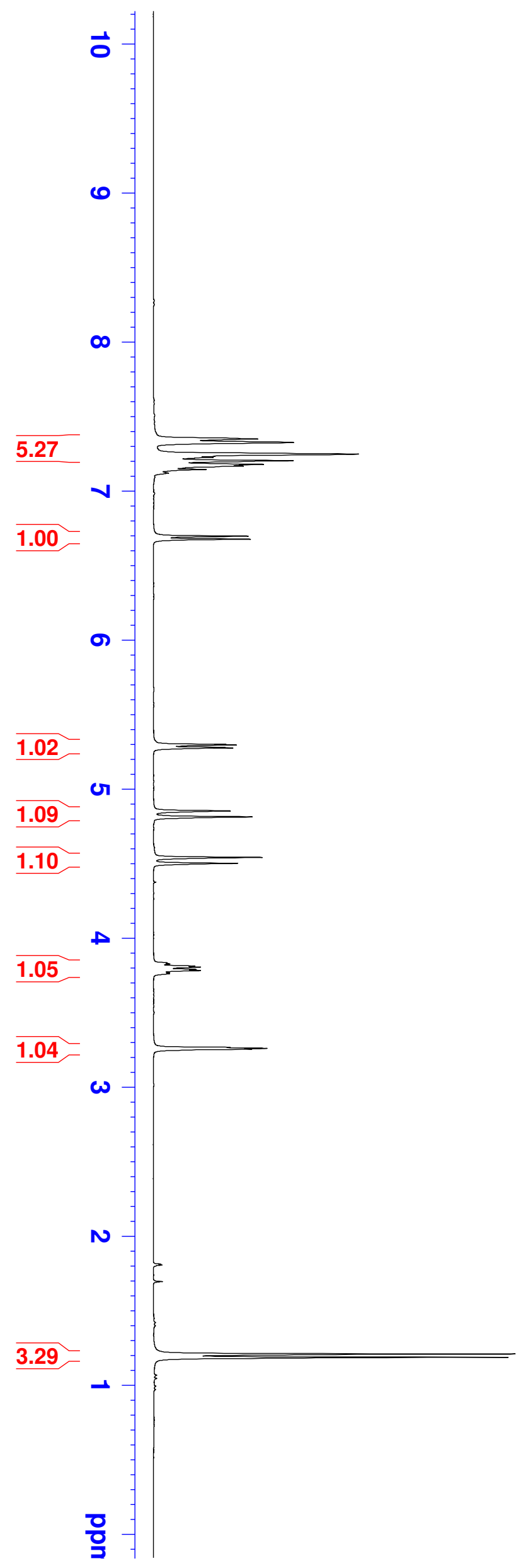

苫

乲

品 $\pm$

$-7.349 \stackrel{\mathrm{O}}{ }$

$\left[\begin{array}{l}7.349 \\ -7.325\end{array}\right.$

-7.247 空

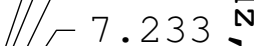

$-7.226$

$-7.203$

7.1780

$\sim 7.173$

$\lfloor 7.167$

$\rrbracket\lfloor 7.144$

$-7.120$

$-6.697$

6.677

$-5.300$

5.296

$-5.280$

5.275

$-4.853$

$-4.813$

$-4.541$

$-4.502$

$-3.834$

$\tau^{3} 3.827$

$-3.812$

$-3.805$

$-3.789$

$-3.783$

$-3.768$

3.761

$-3.267$

$-3.259$

$-3.254$

1.209
$-\quad 1.187$ 


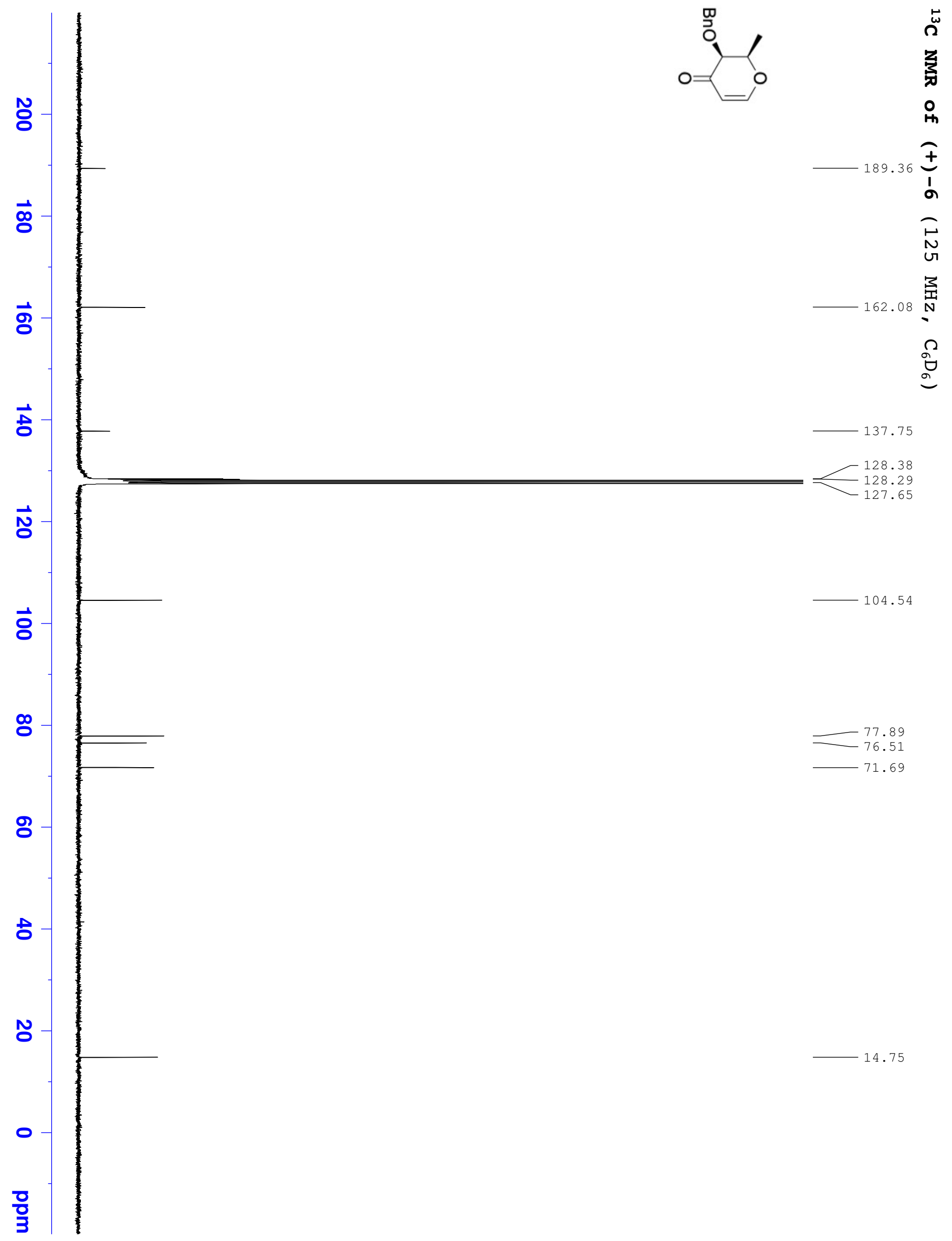


${ }^{1} \mathrm{H}$ NMR of $(-)-6\left(500 \mathrm{MHz}, \mathrm{C}_{6} \mathrm{D}_{6}\right)$

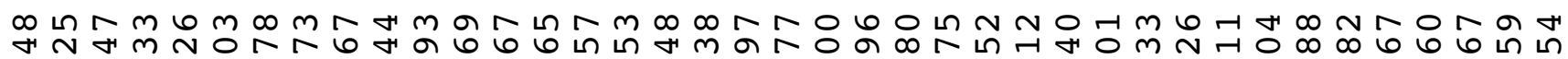

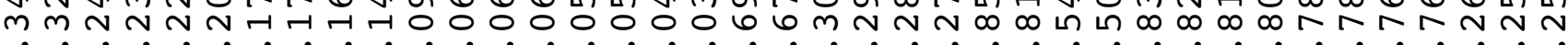

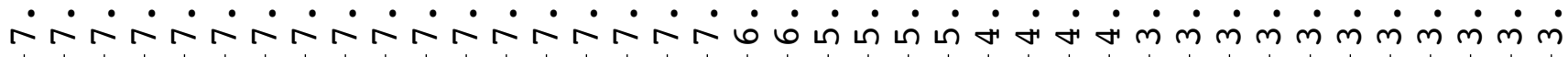
$\begin{array}{lll}\infty & 6 \\ 0 & \infty\end{array}$<smiles>C[C@H]1OC=CC(=O)[C@@H]1OCc1ccccc1</smiles>
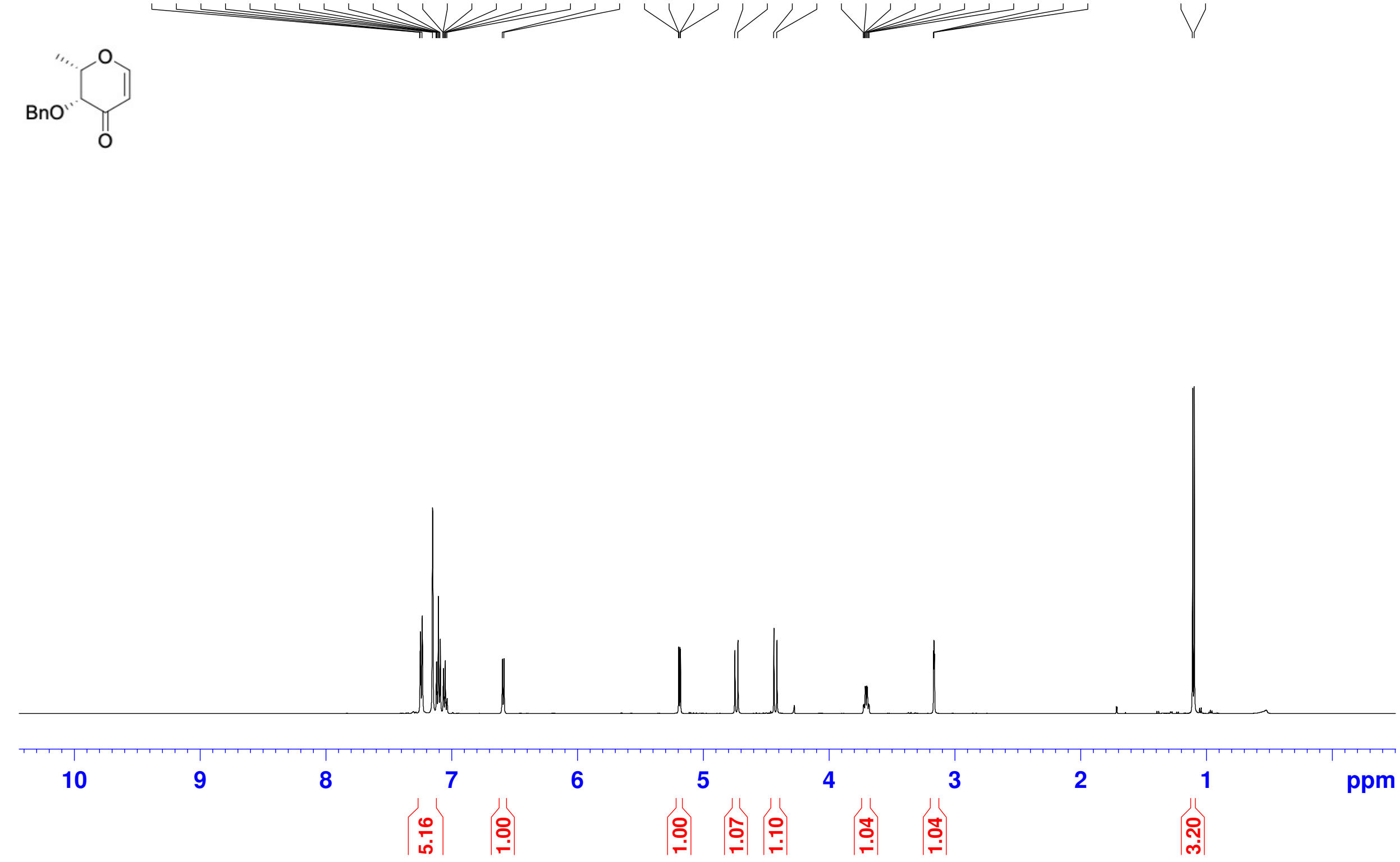


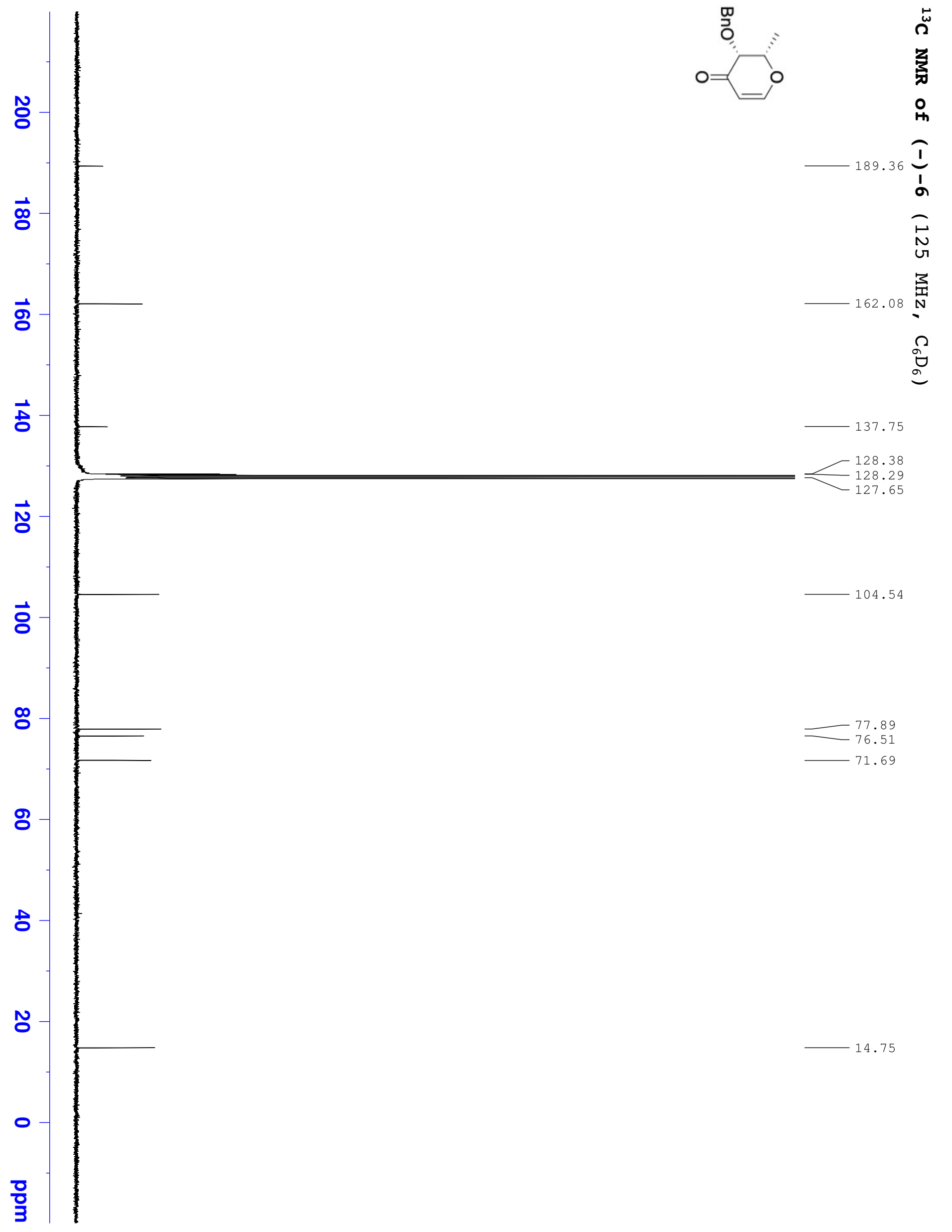


${ }^{1} \mathrm{H}$ NMR of (-) -22 (500 $\left.\mathrm{MHz}, \mathrm{CDCl}_{3}\right)$

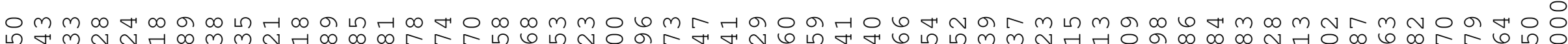

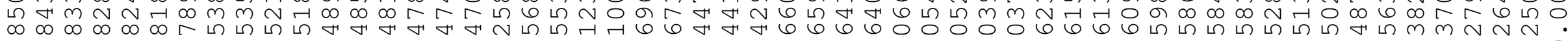

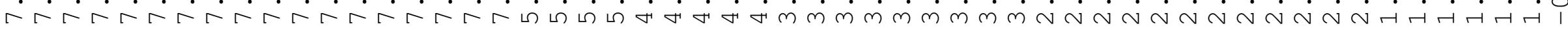<smiles>CC[C@H]1CC(=O)[C@@H](O[N+](=O)[O-])[C@@H](C)O1</smiles>

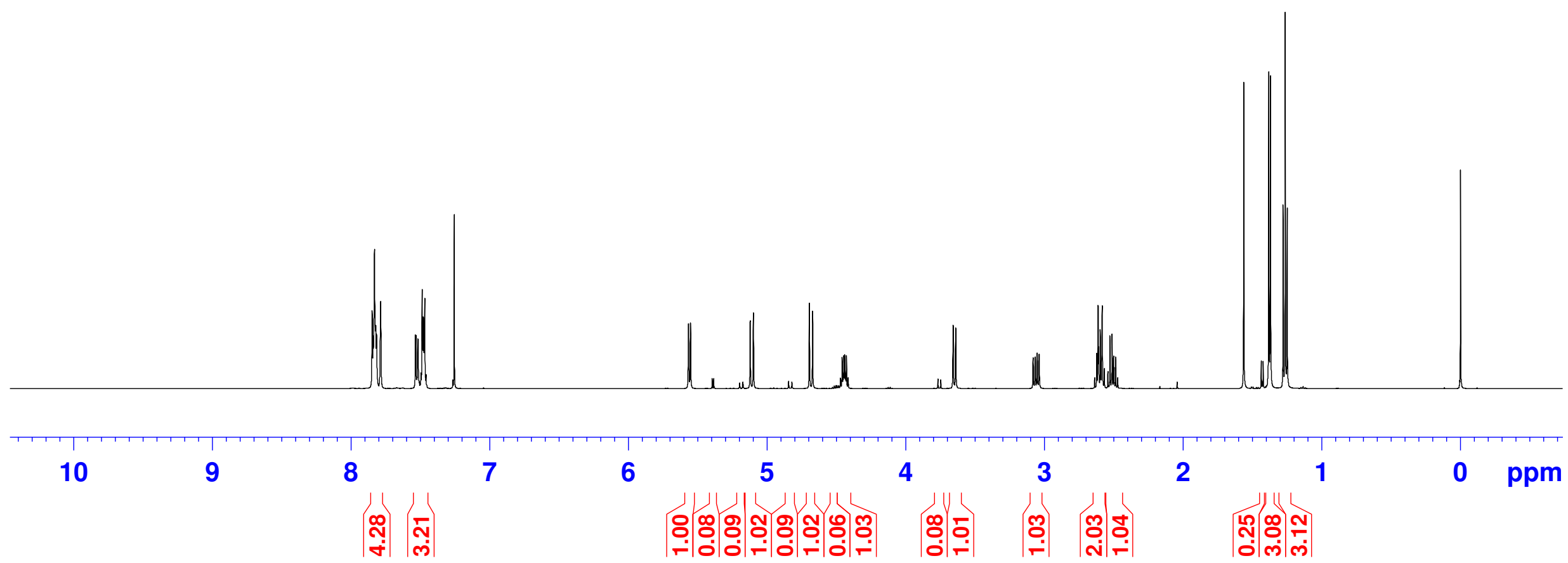


${ }^{13} \mathrm{C}$ NMR of (-)-22 (125 $\left.\mathrm{MHz}, \mathrm{CDCl}_{3}\right)$
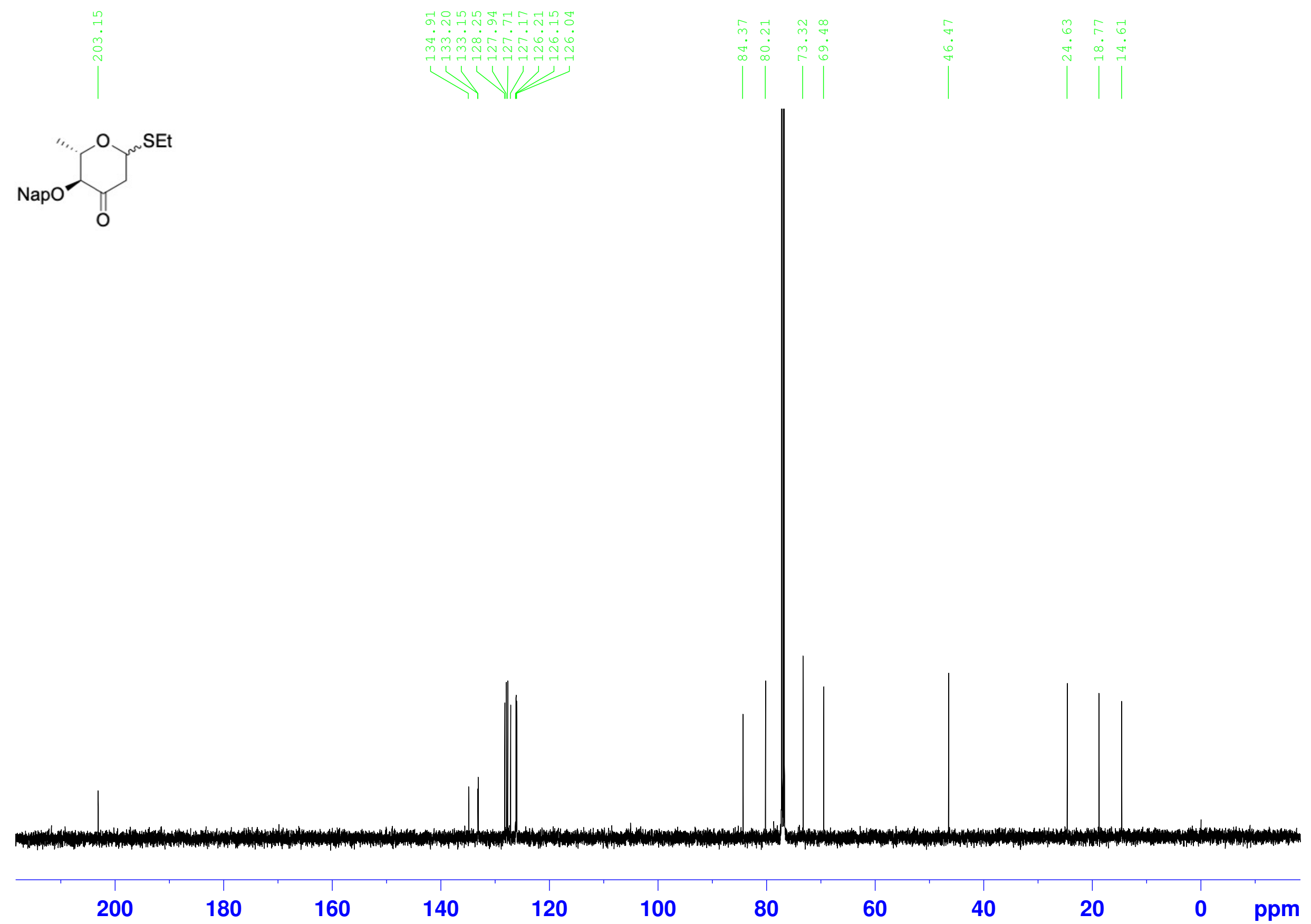
${ }^{1} \mathrm{H}$ NMR of (-)-7 (500 $\left.\mathrm{MHz}, \mathrm{CDCl}_{3}\right)$

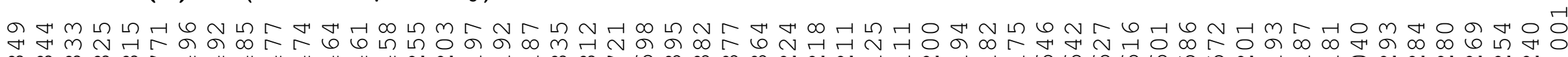
$\infty, \infty \infty .+\cdots$.

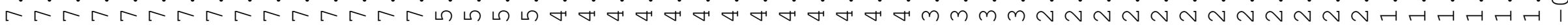
(n)

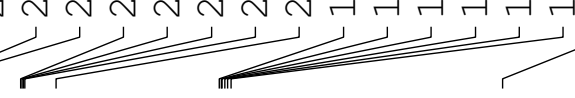

$\mathrm{NapO}$ TH

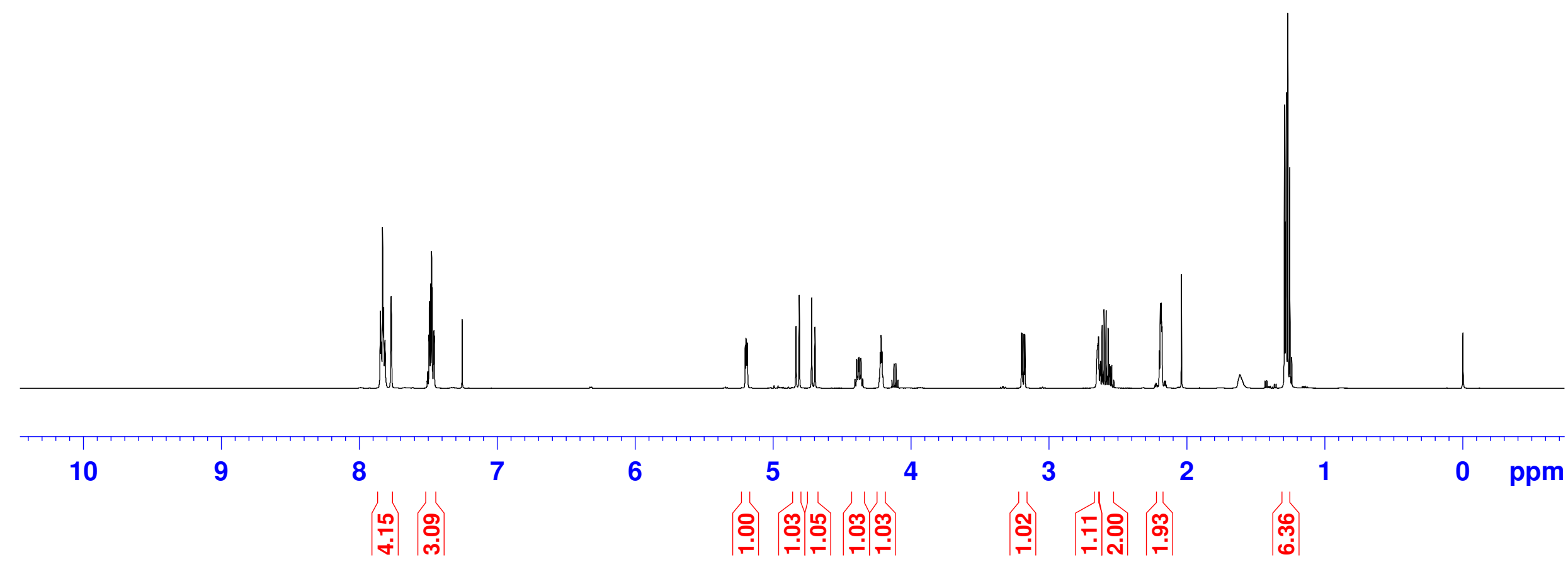


${ }^{13} \mathrm{C}$ NMR of (-)-7 (125 $\left.\mathrm{MHz}, \mathrm{CDCl}_{3}\right)$

$$
\text { Napo the }
$$
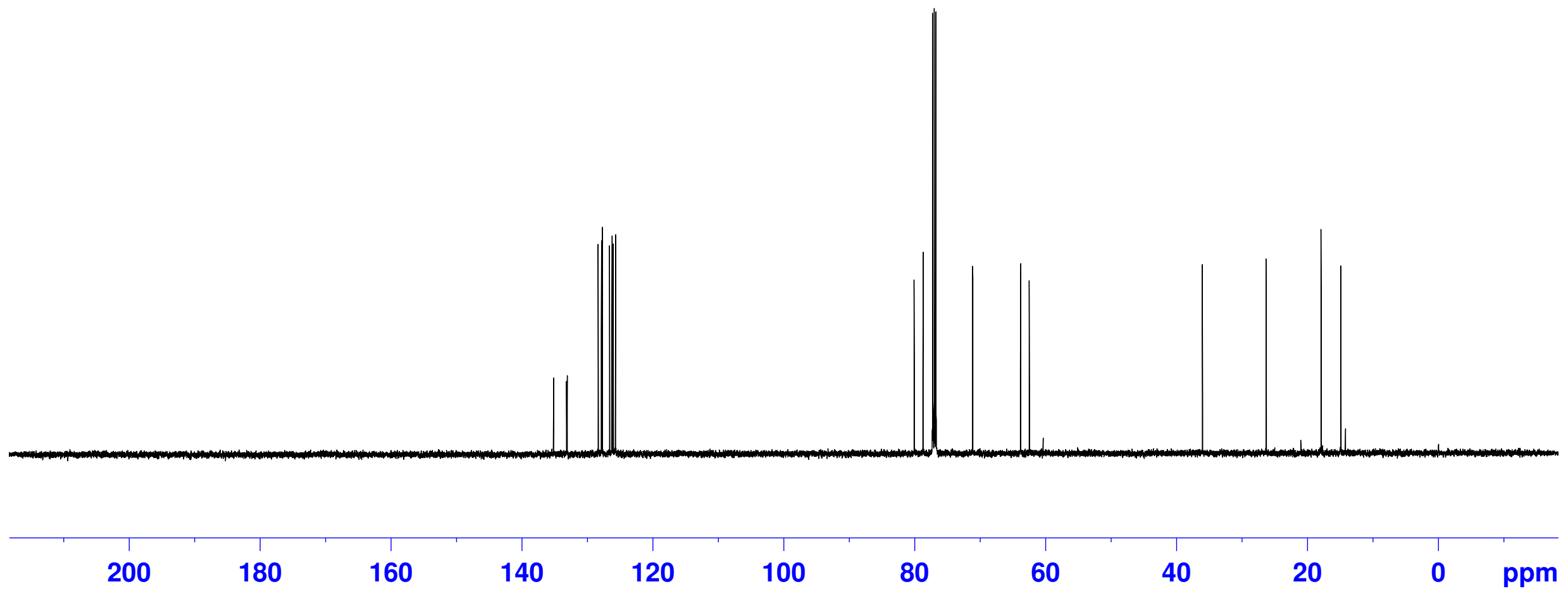
${ }^{1} \mathrm{H}$ NMR of (-)-23 (500 $\left.\mathrm{MHz}, \mathrm{CDCl}_{3}\right)$

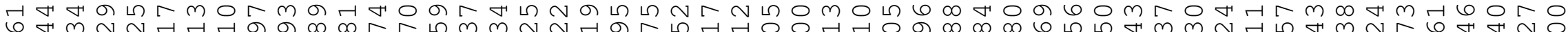

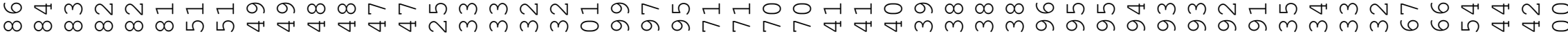

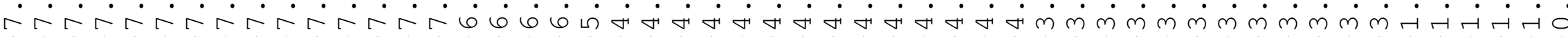
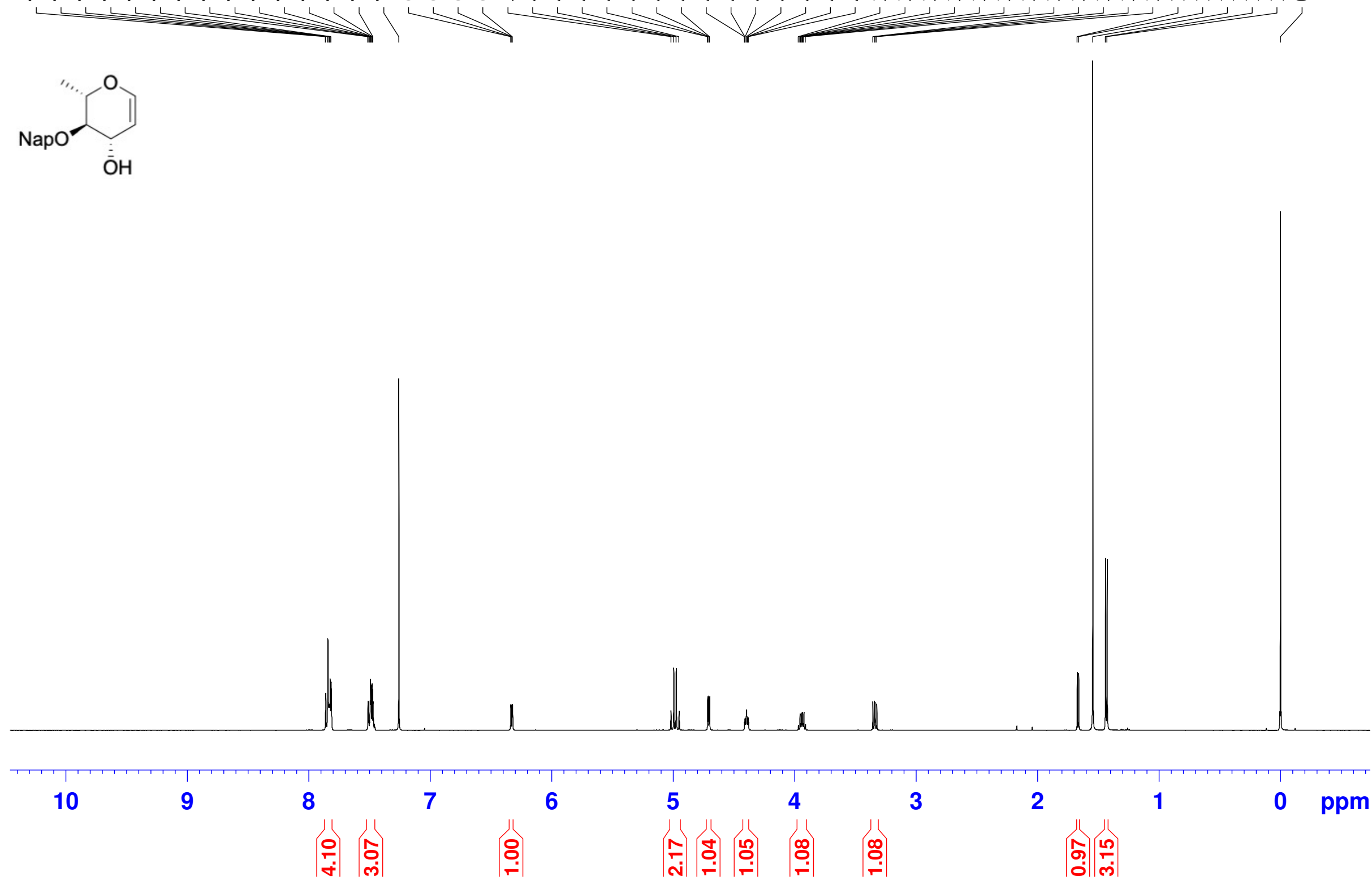
${ }^{13} \mathrm{C}$ NMR of (-)-23 (125 $\left.\mathrm{MHz}, \mathrm{CDCl}_{3}\right)$
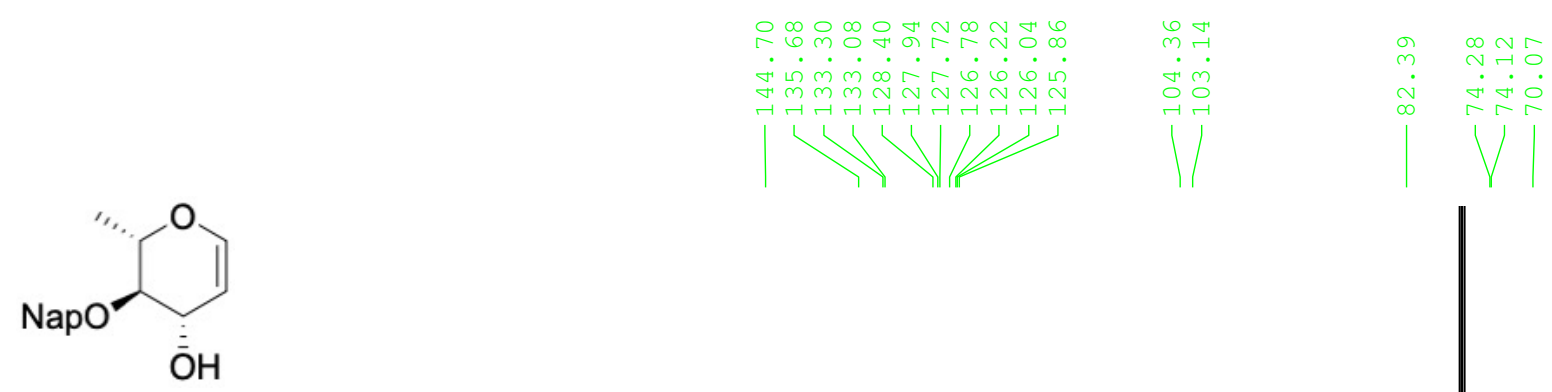

ŌH

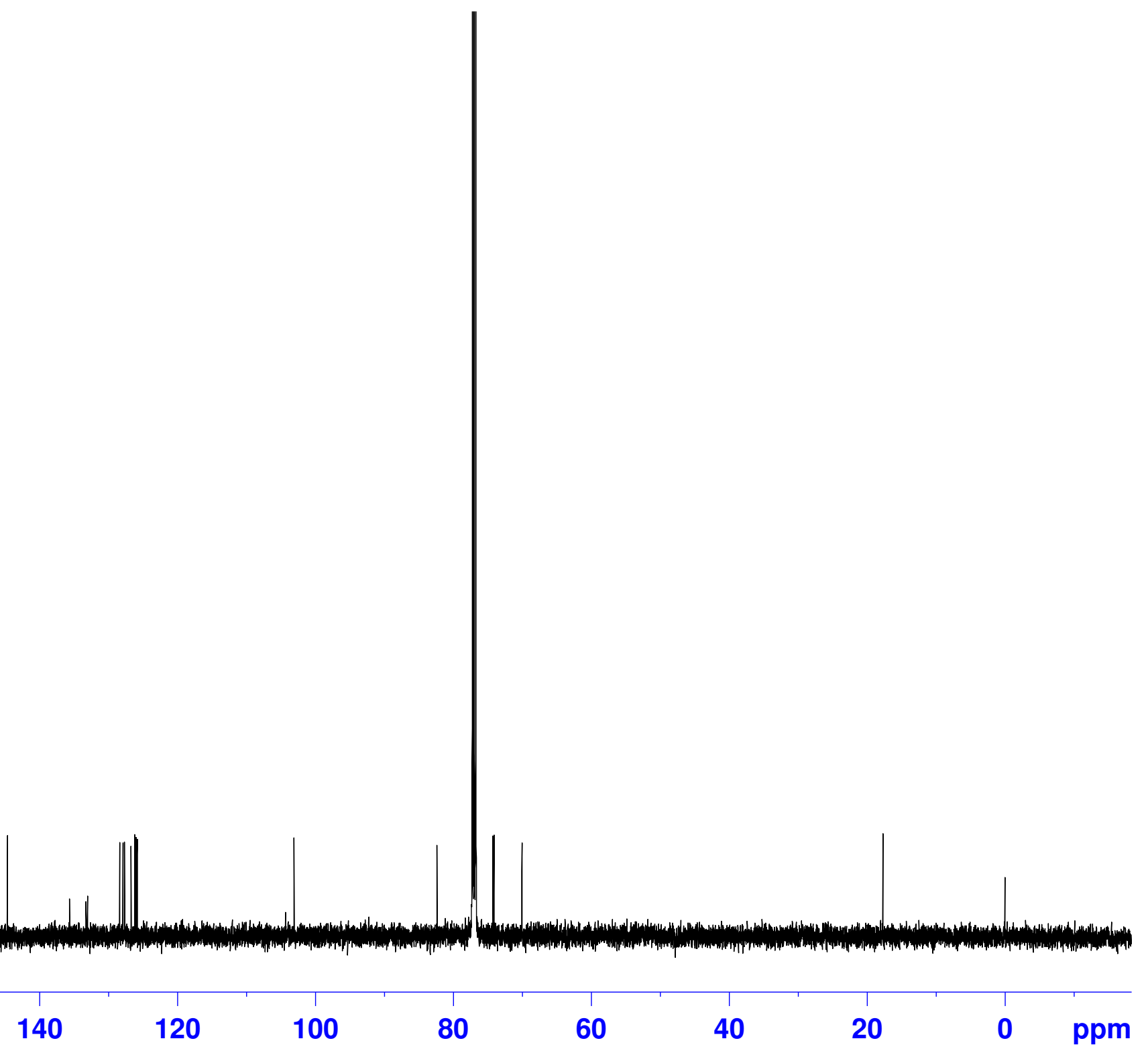


${ }^{1} \mathrm{H}$ NMR of $(-)-24\left(500 \mathrm{MHz}, \mathrm{CDCl}_{3}\right)$

에가

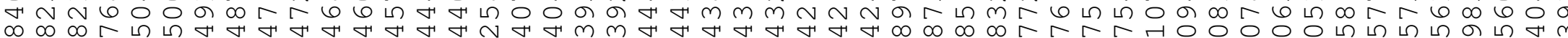

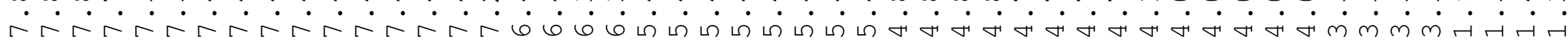
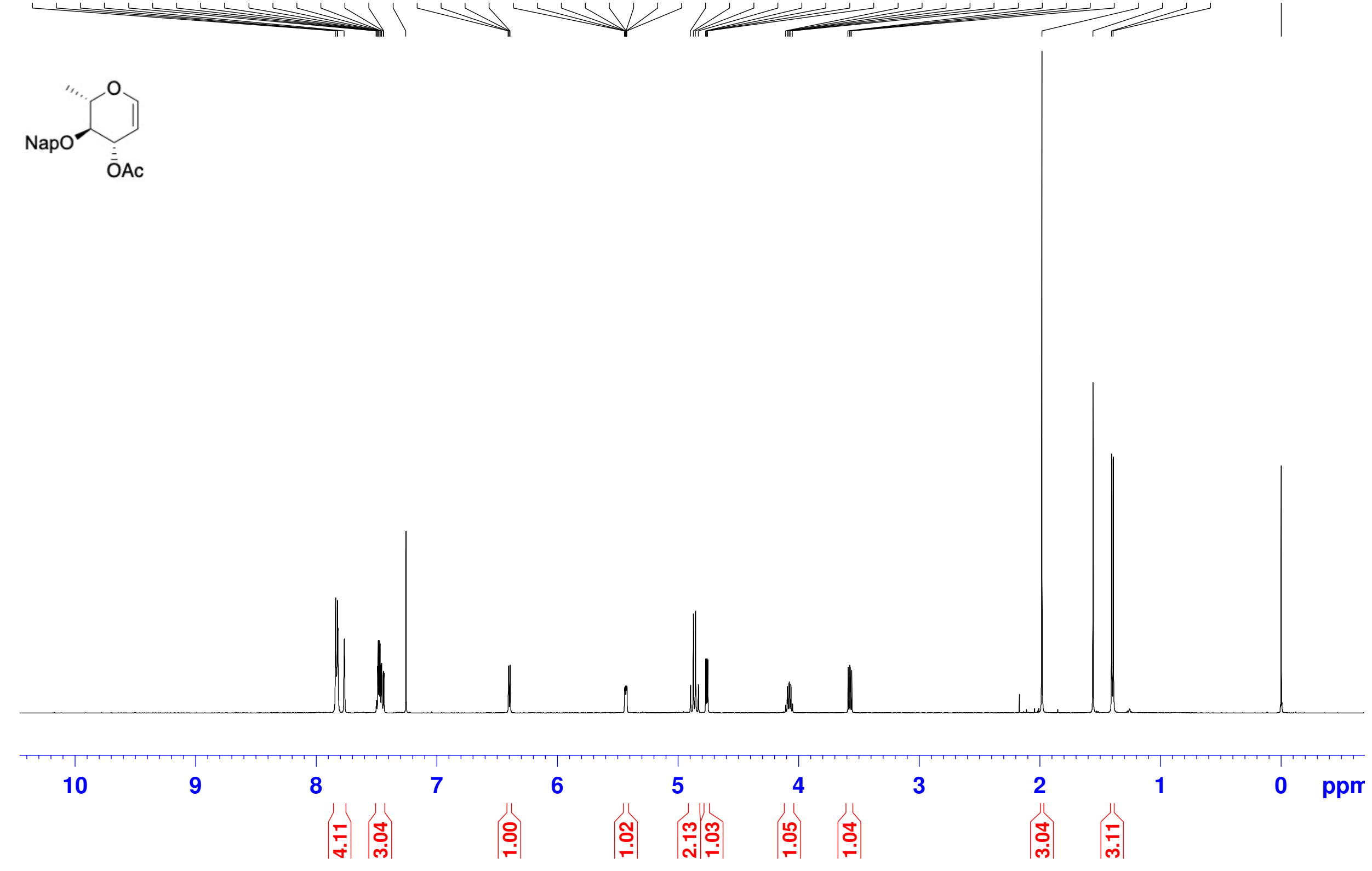
${ }^{13} \mathrm{C}$ NMR of (-) $\mathbf{- 2 4}\left(125 \mathrm{MHz}, \mathrm{CDCl}_{3}\right)$
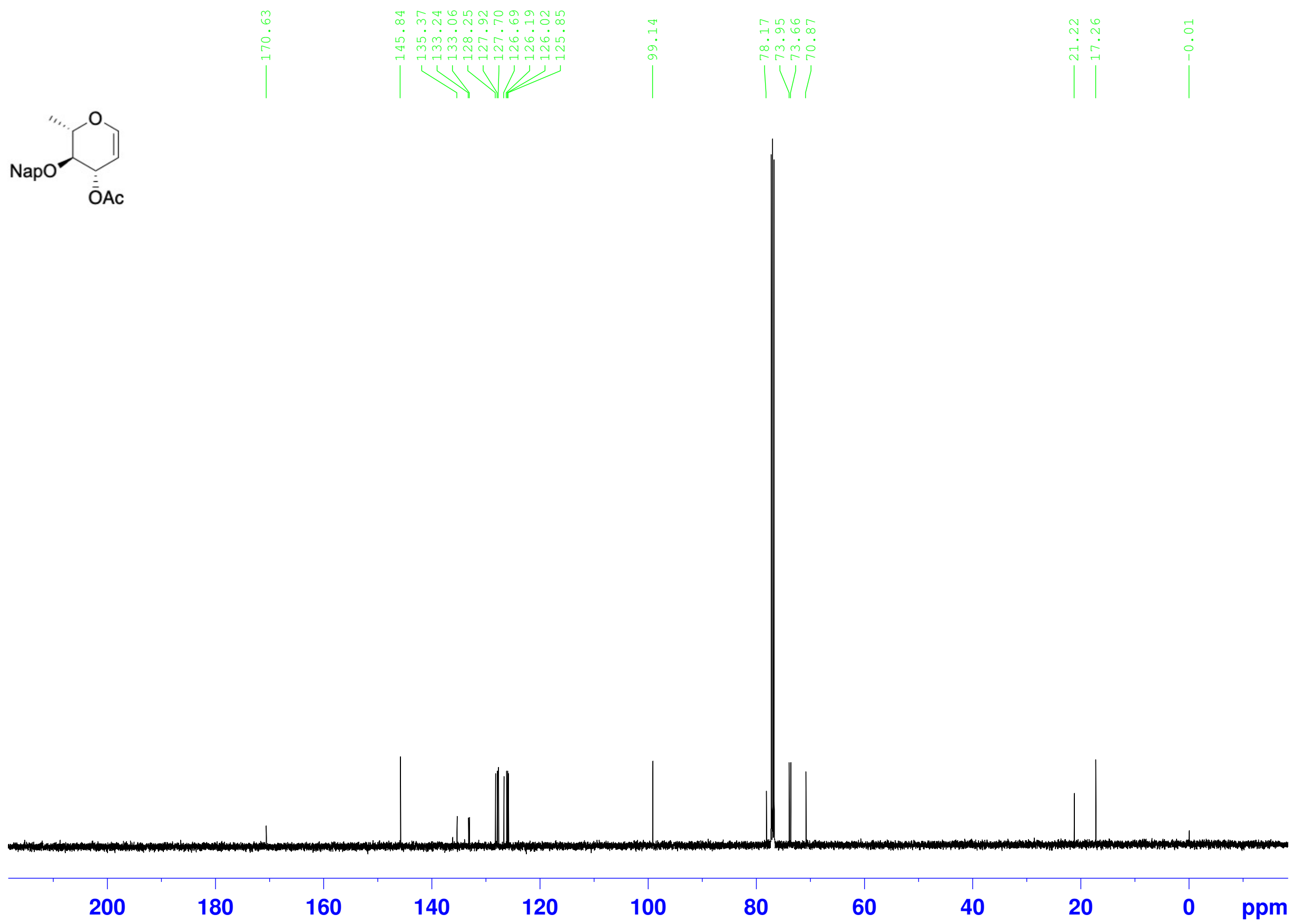
${ }^{1} \mathbf{H}$ NMR of (-) $-8\left(500 \mathrm{MHz}, \mathrm{CDCl}_{3}\right)$

H

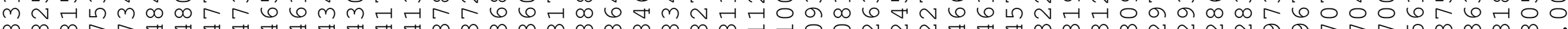

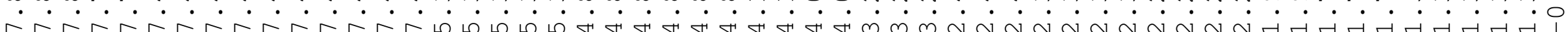

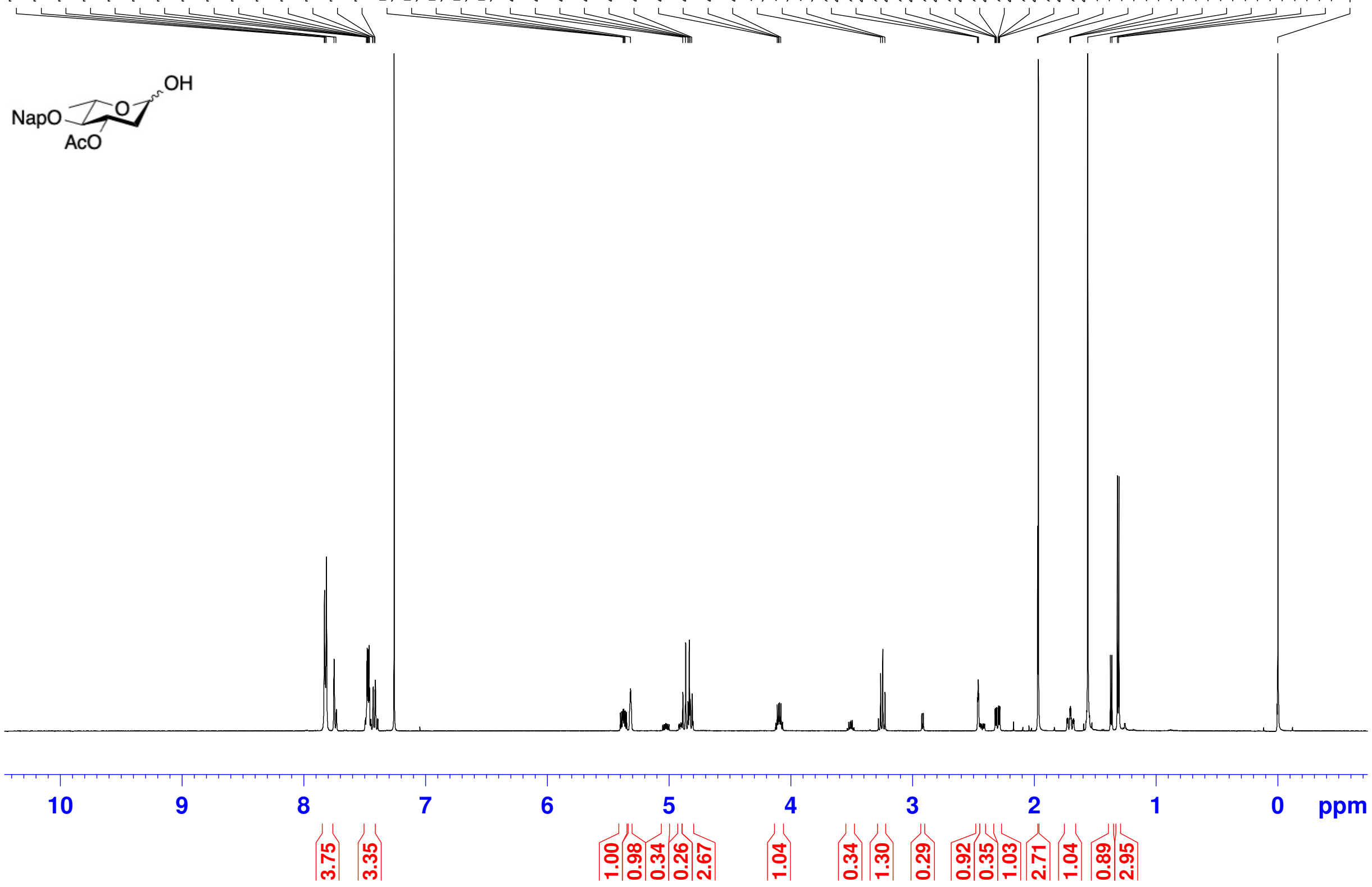


${ }^{13} \mathrm{C}$ NMR of (-)-8 (125 $\left.\mathrm{MHz}, \mathrm{CDCl}_{3}\right)$

$$
\mathrm{NapO} \underset{\mathrm{AcO}}{\mathrm{TCO}^{\mathrm{O}}}
$$
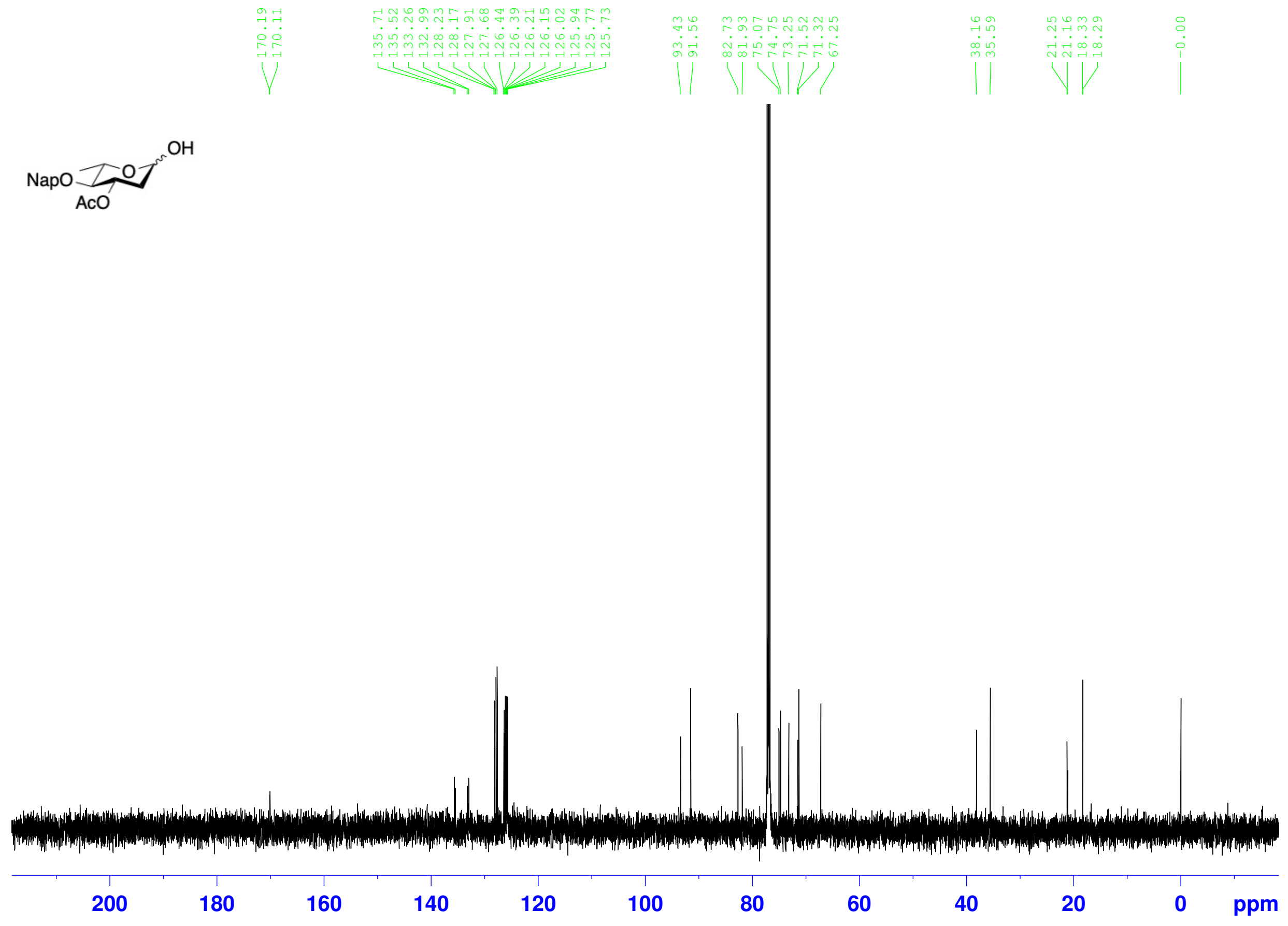
${ }^{1} \mathrm{H}$ NMR of $(+)-25\left(500 \mathrm{MHz}, \mathrm{CDCl}_{3}\right)$

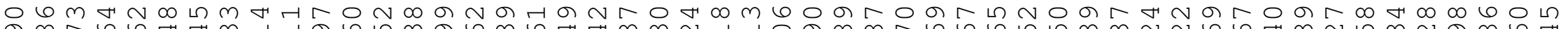
m m m m m m m

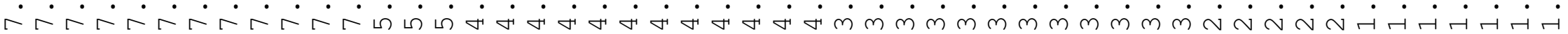

m
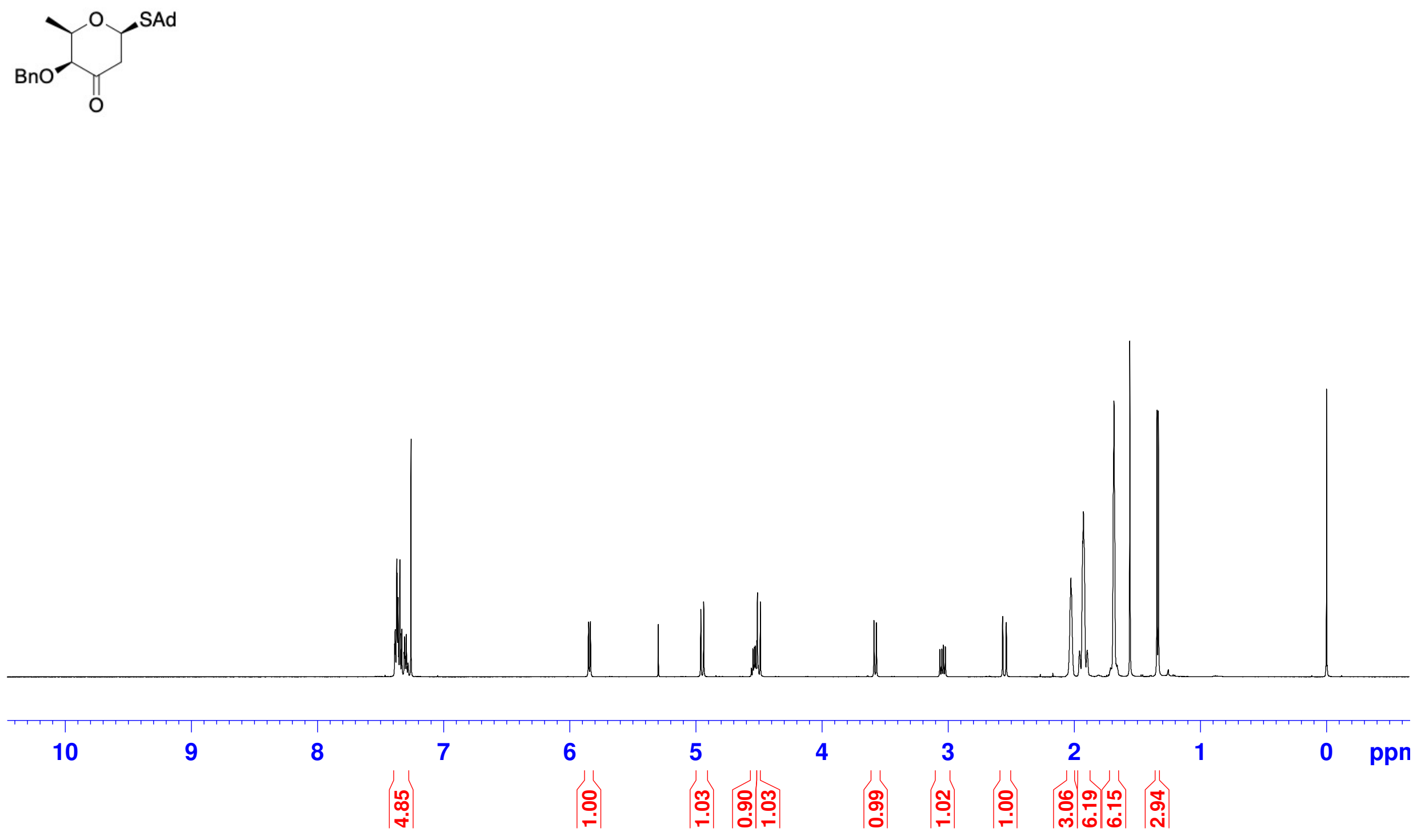
${ }^{13} \mathrm{C}$ NMR of $(+)-25\left(125 \mathrm{MHz}, \mathrm{CDCl}_{3}\right)$
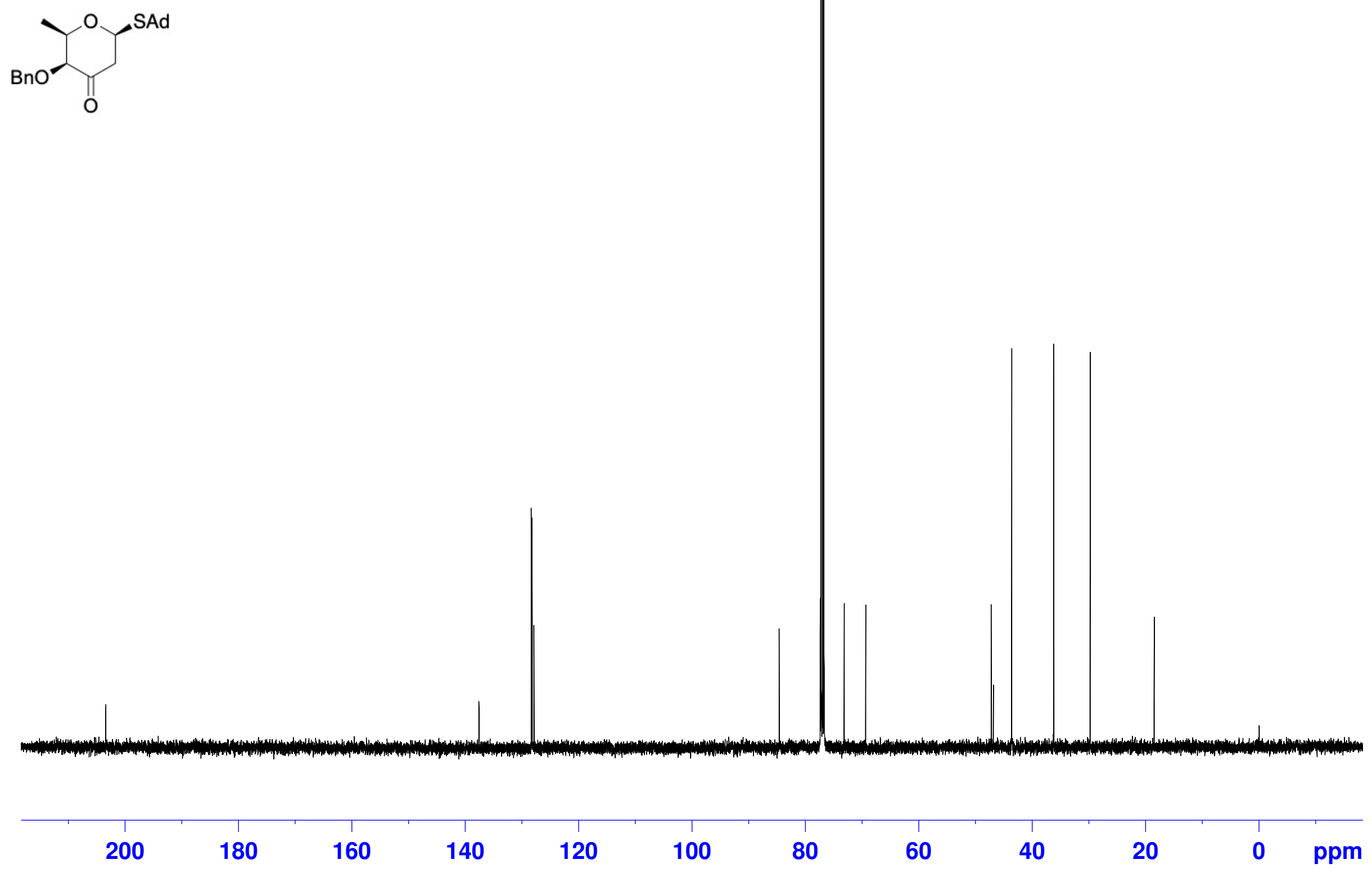
${ }^{1} \mathrm{H}$ NMR of $(+)-9\left(500 \mathrm{MHz}, \mathrm{CDCl}_{3}\right)$

○の 네네

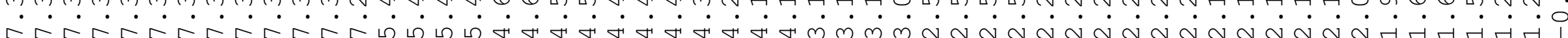
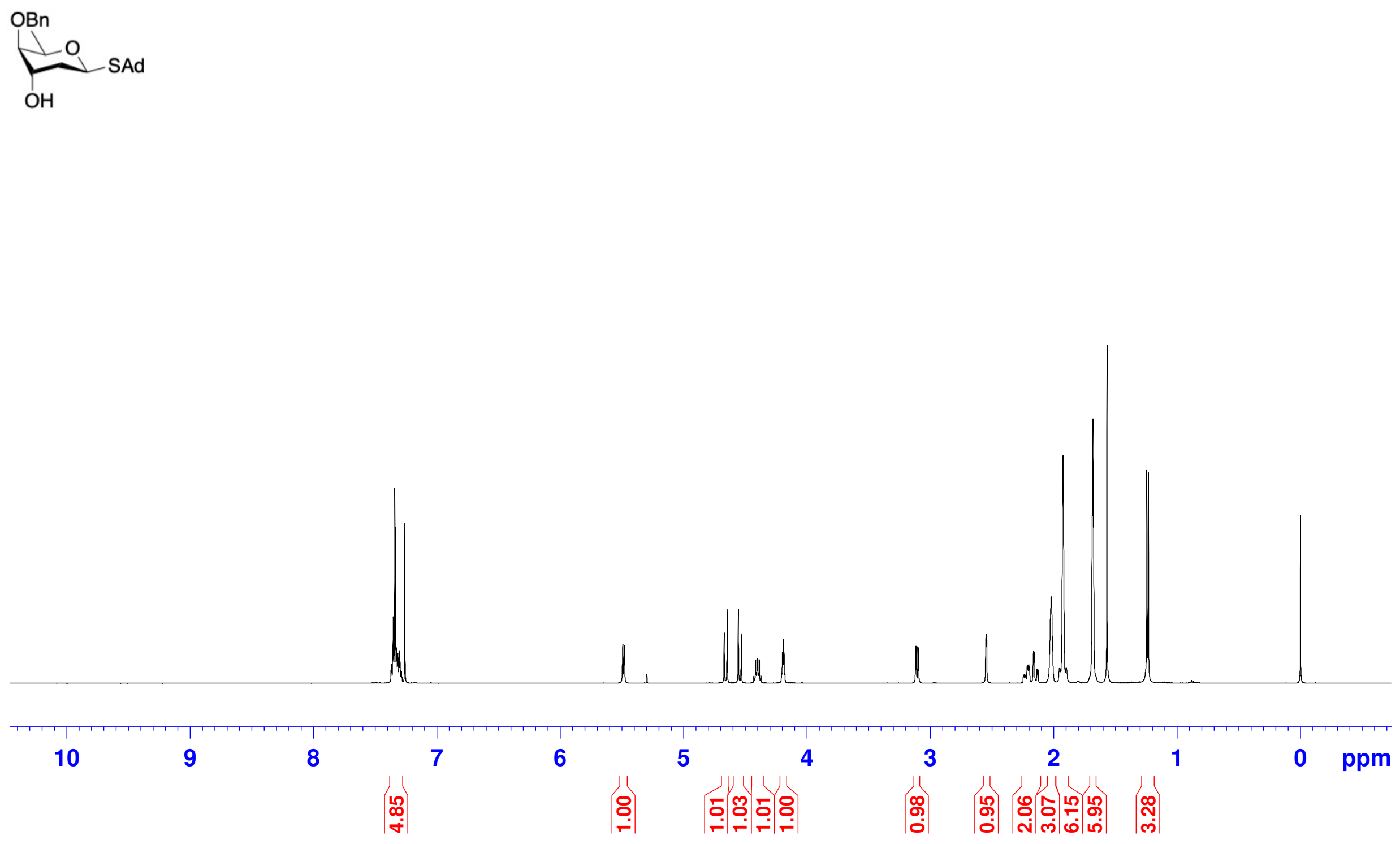
${ }^{13} \mathrm{C}$ NMR of (+)-9 (125 $\left.\mathrm{MHz}, \mathrm{CDCl}_{3}\right)$
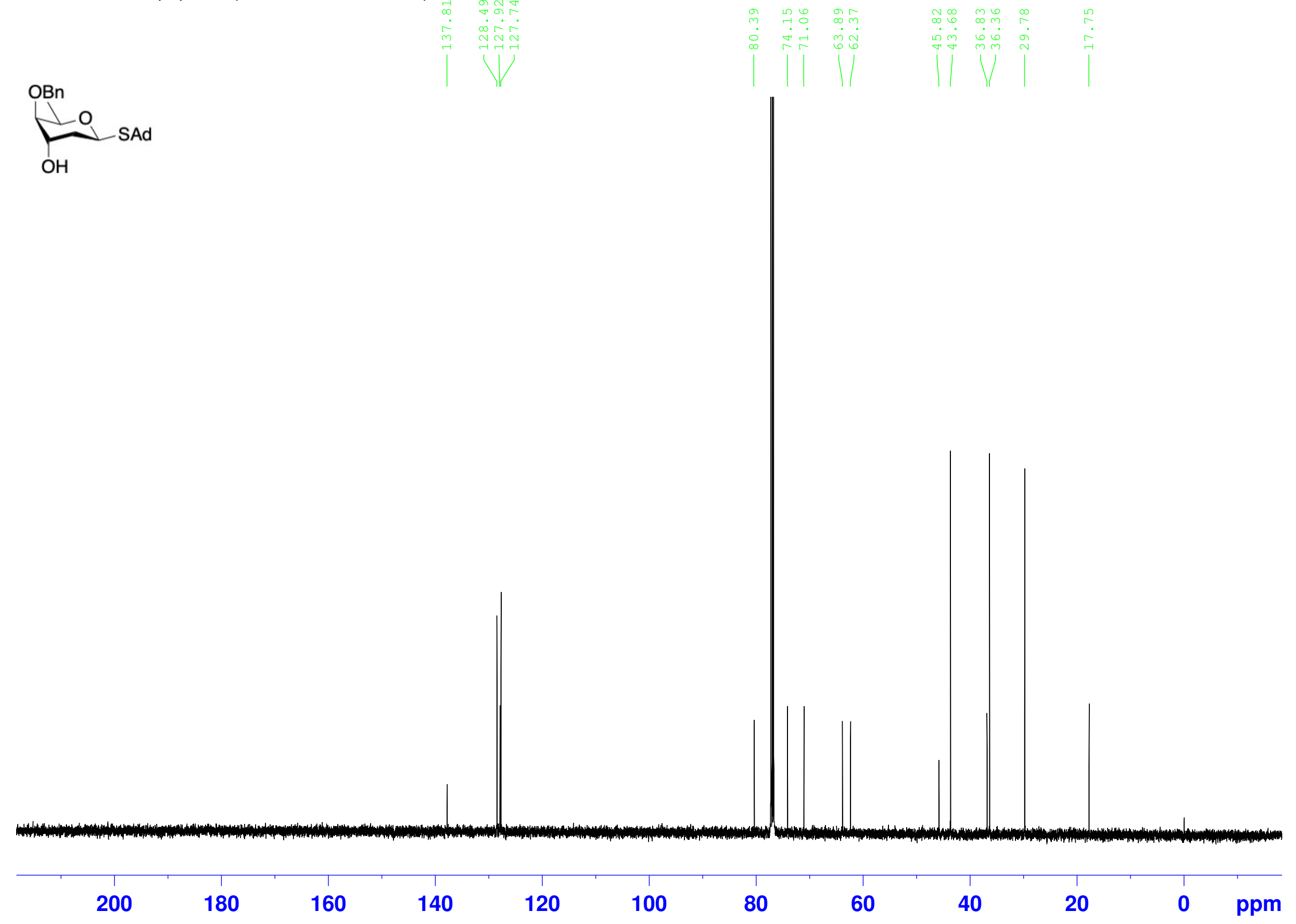
${ }^{1}{ }_{H-} 1_{H}$ Gr. COSY of $(+)-9\left(500 \mathrm{MHz}, \mathrm{CDCl}_{3}\right)$

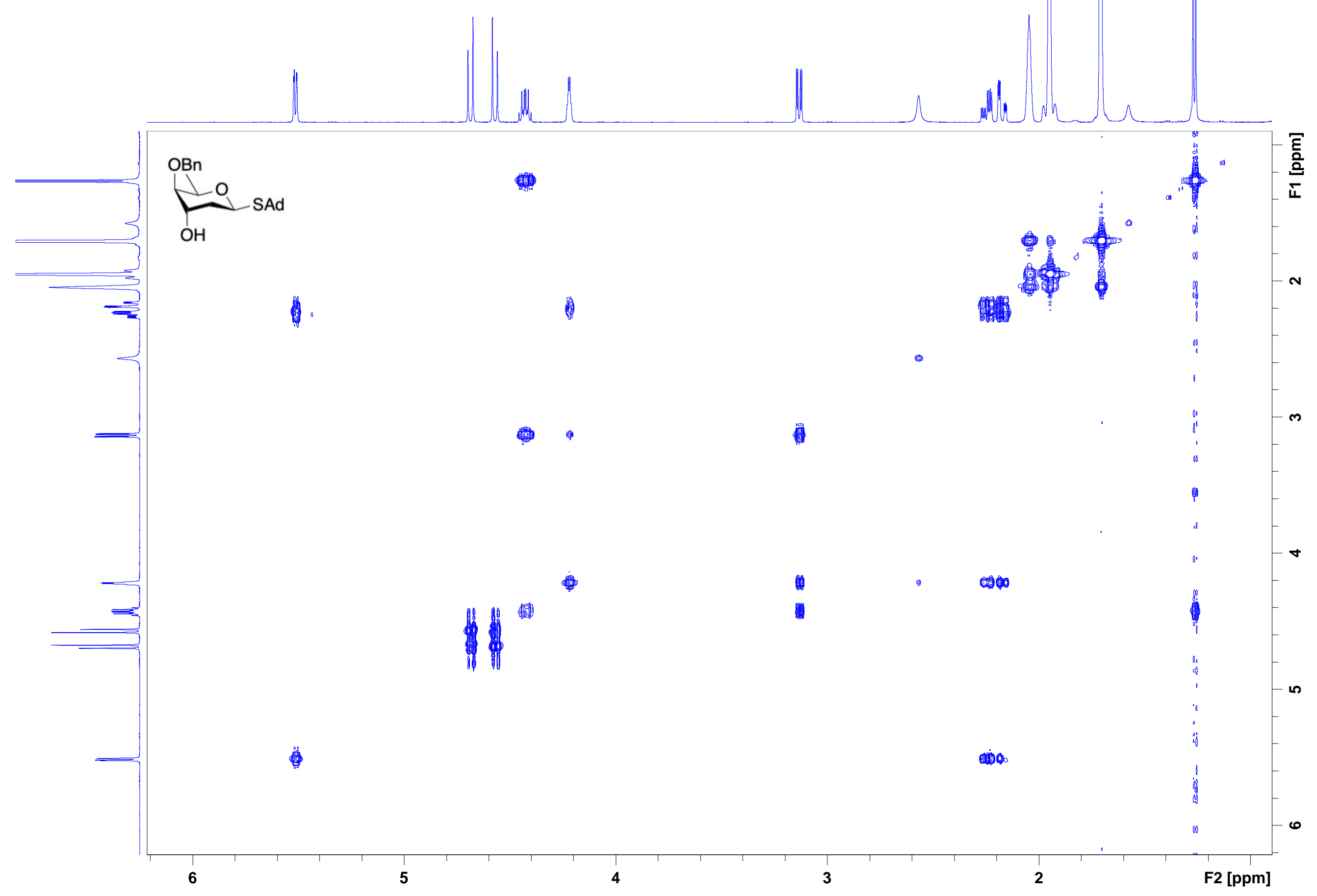




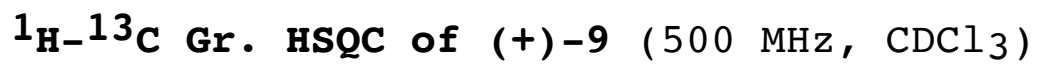

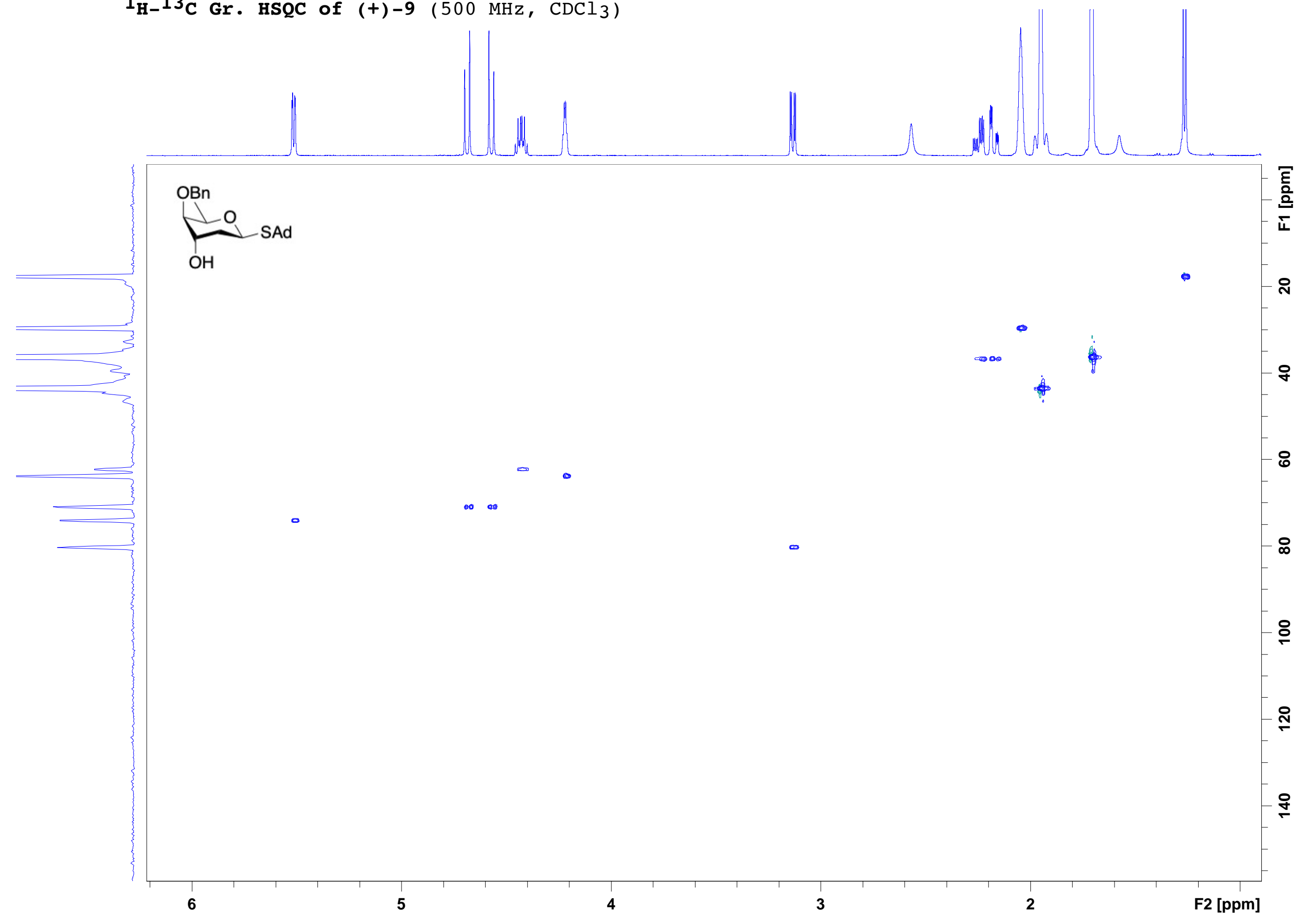


${ }^{1} \mathrm{H}$ NMR of (-) $\mathbf{- 2 6}\left(500 \mathrm{MHz}, \mathrm{CDCl}_{3}\right)$

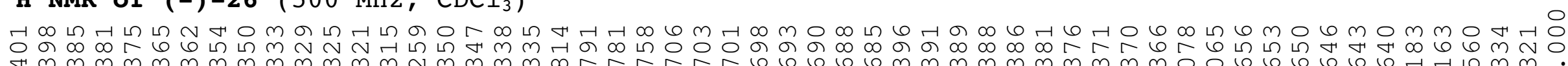

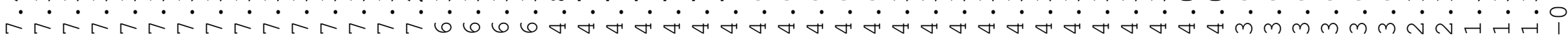<smiles>CCCO[C@@H]1[C@H](O)C=CO[C@@H]1C</smiles>

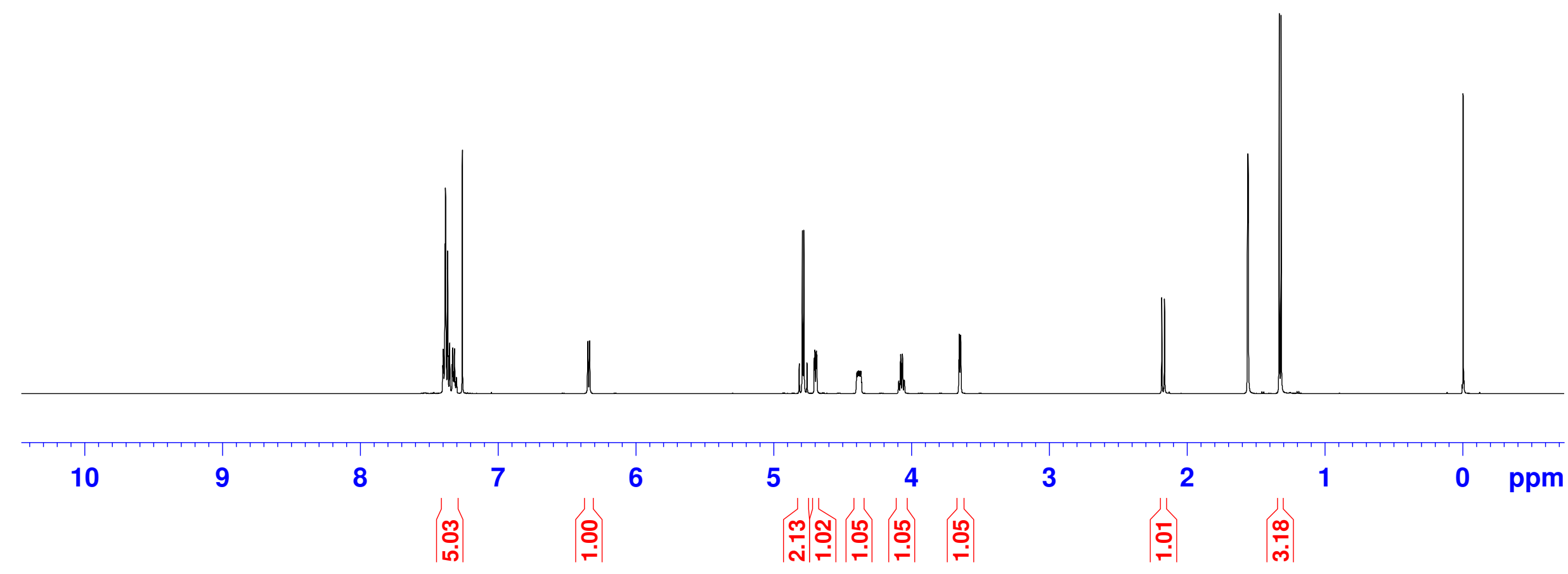


${ }^{13} \mathrm{C}$ NMR of (-)-26 (125 $\left.\mathrm{MHz}, \mathrm{CDCl}_{3}\right)$<smiles>C[C@H]1OC=C[C@H](O)[C@H]1O[B]c1ccccc1</smiles>

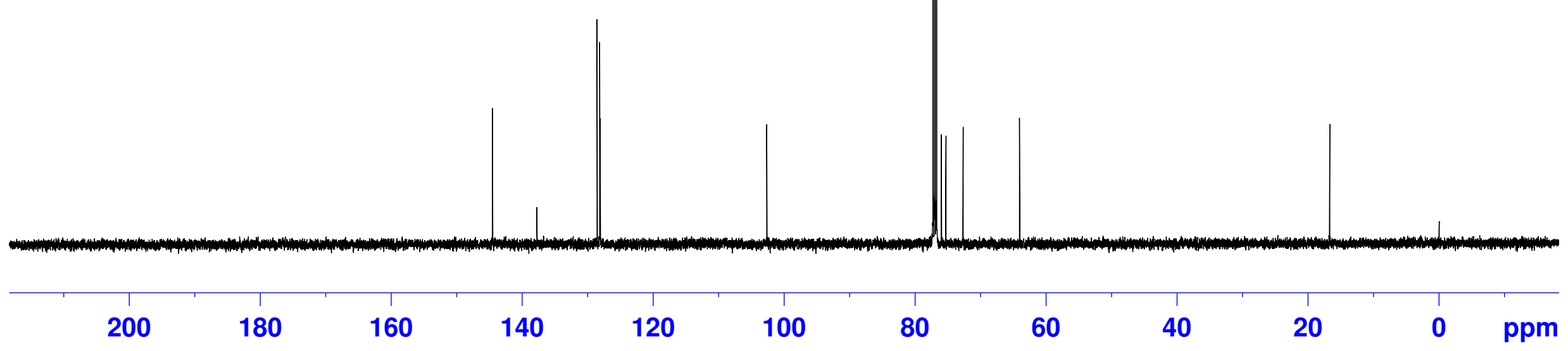


${ }^{1} \mathrm{H}$ NMR of (-)-27 (500 $\left.\mathrm{MHz}, \mathrm{CDCl}_{3}\right)$

e HONHGR

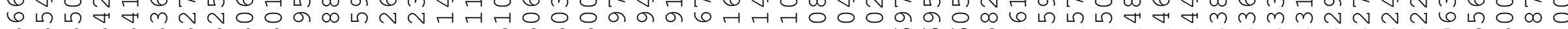

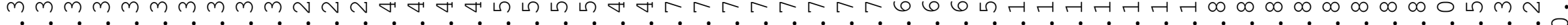

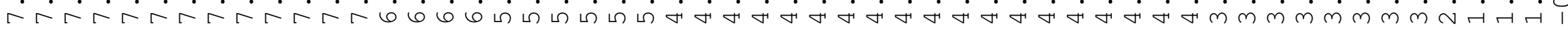
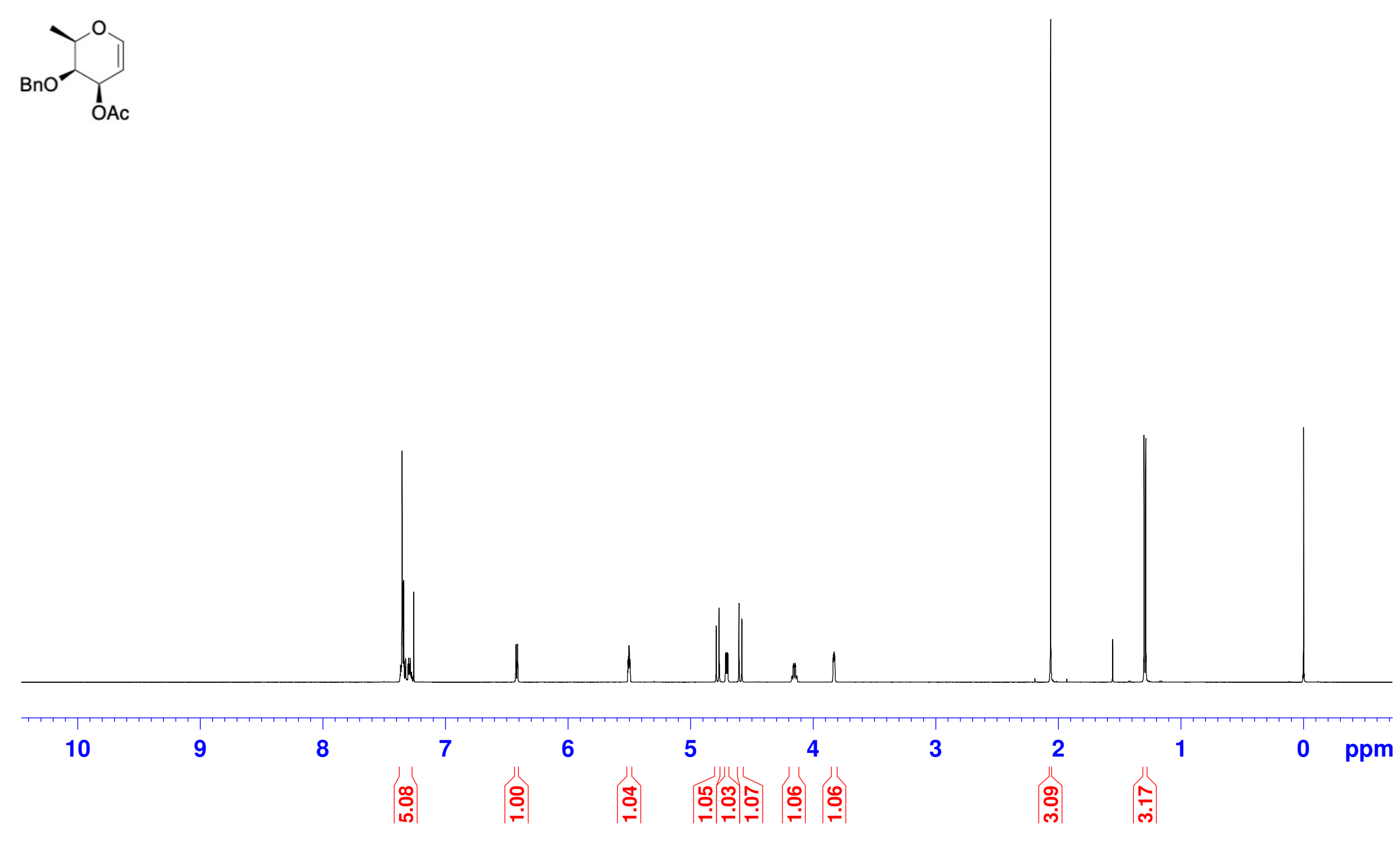
${ }^{13} \mathrm{C}$ NMR of (-)-27 (125 $\left.\mathrm{MHz}, \mathrm{CDCl}_{3}\right)$
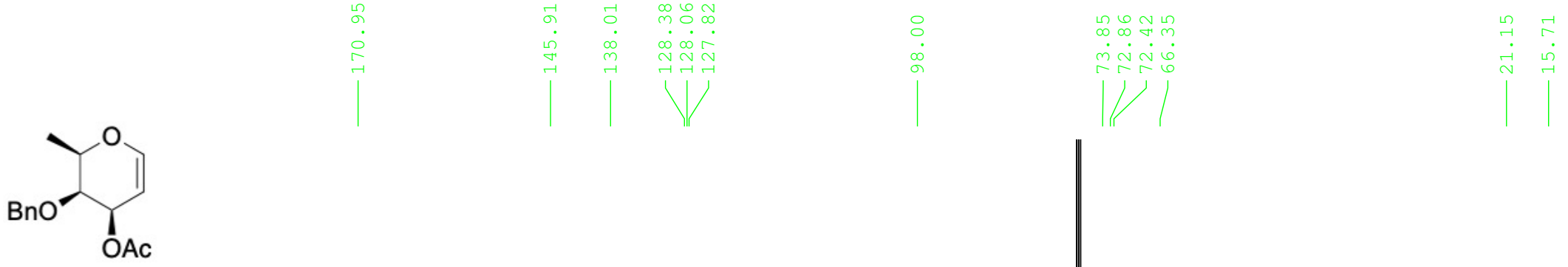

0
$\vdots$
$\vdots$
1

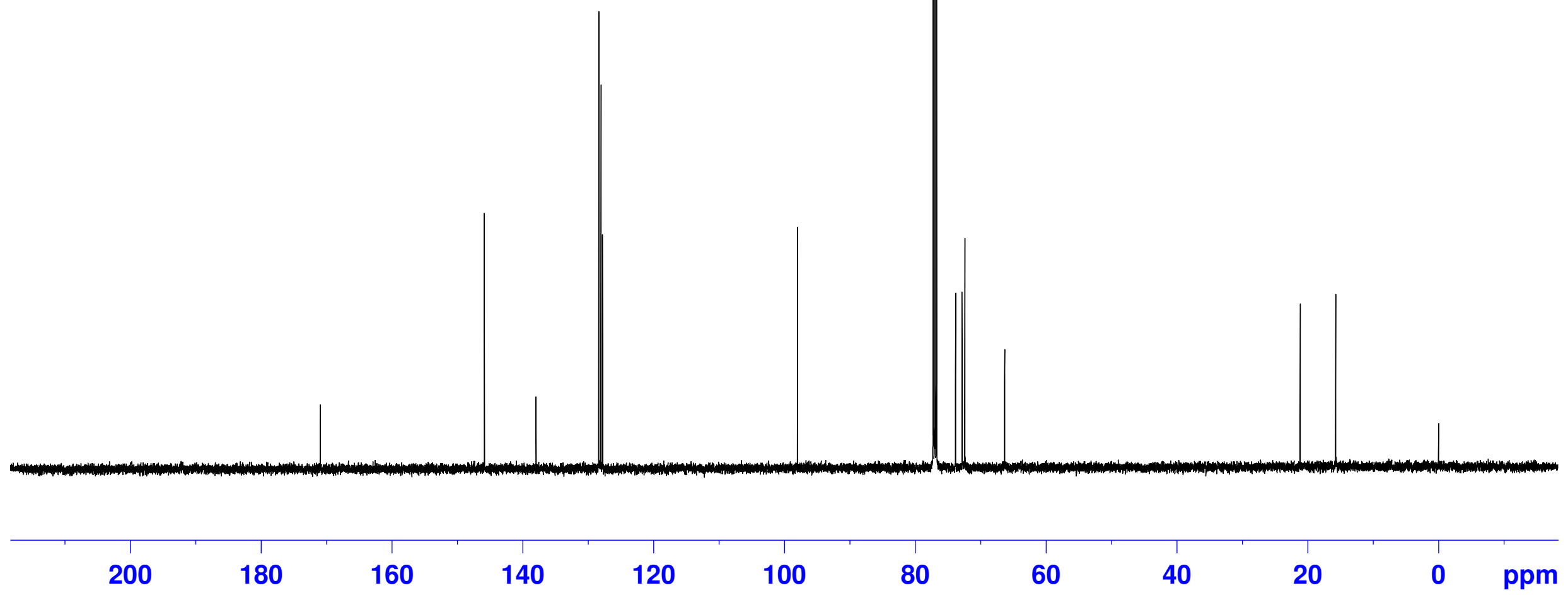


${ }^{1} \mathbf{H}$ NMR of $(+)-10\left(500 \mathrm{MHz}, \mathrm{CDCl}_{3}\right)$

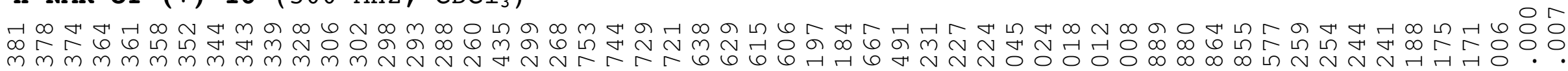

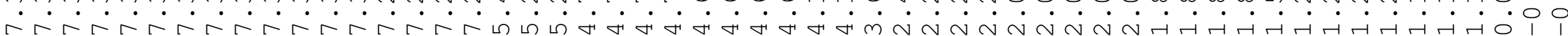<smiles>CC(=O)OC1C[C@@H](O)OC(=O)C1Cc1ccccc1</smiles> 
${ }^{13} \mathrm{C}$ NMR of (+) $-10\left(125 \mathrm{MHz}, \mathrm{CDCl}_{3}\right)$<smiles>CC(=O)OC1C[C@H](O)OC(Br)[C@H]1OCc1ccccc1</smiles>
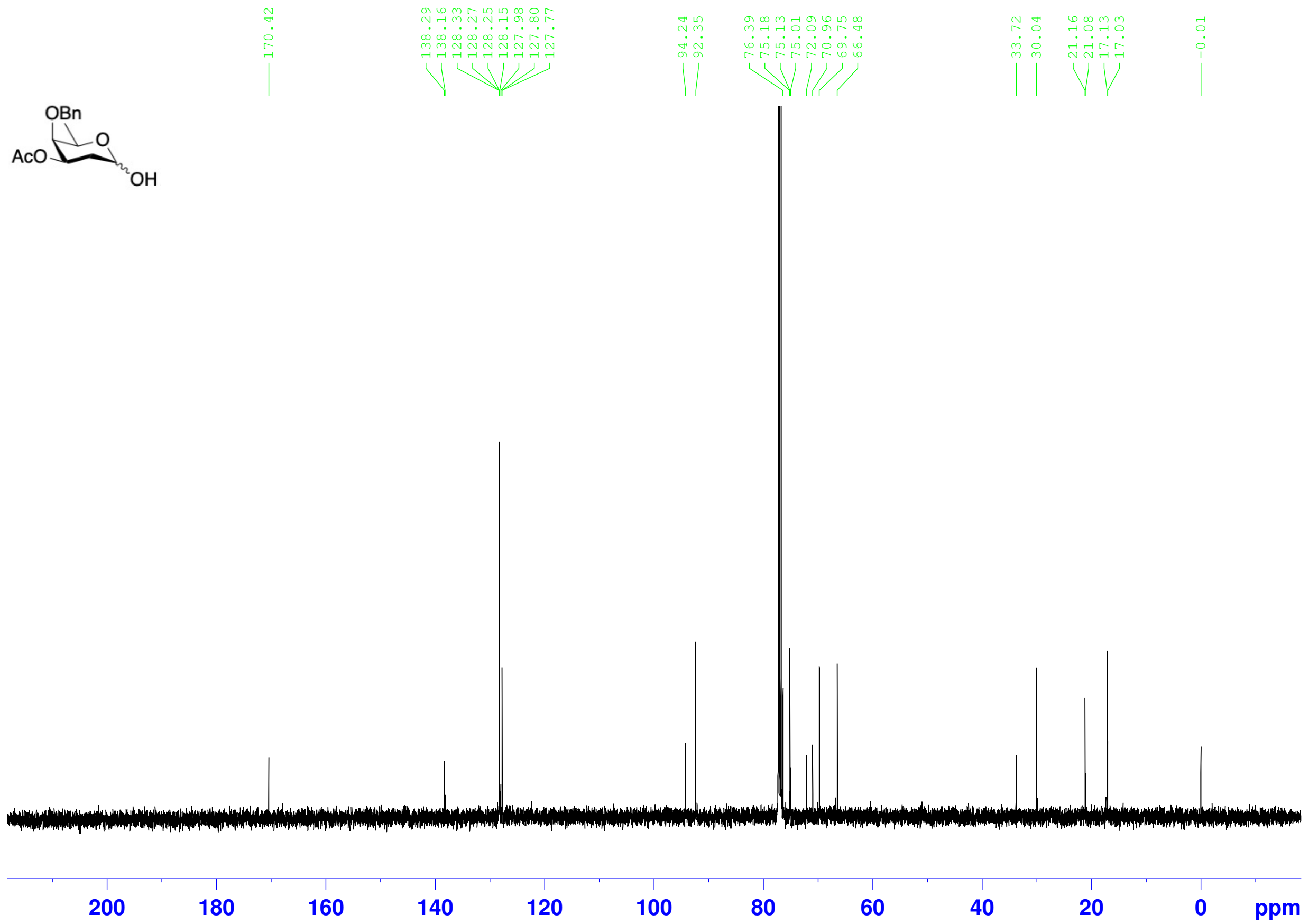


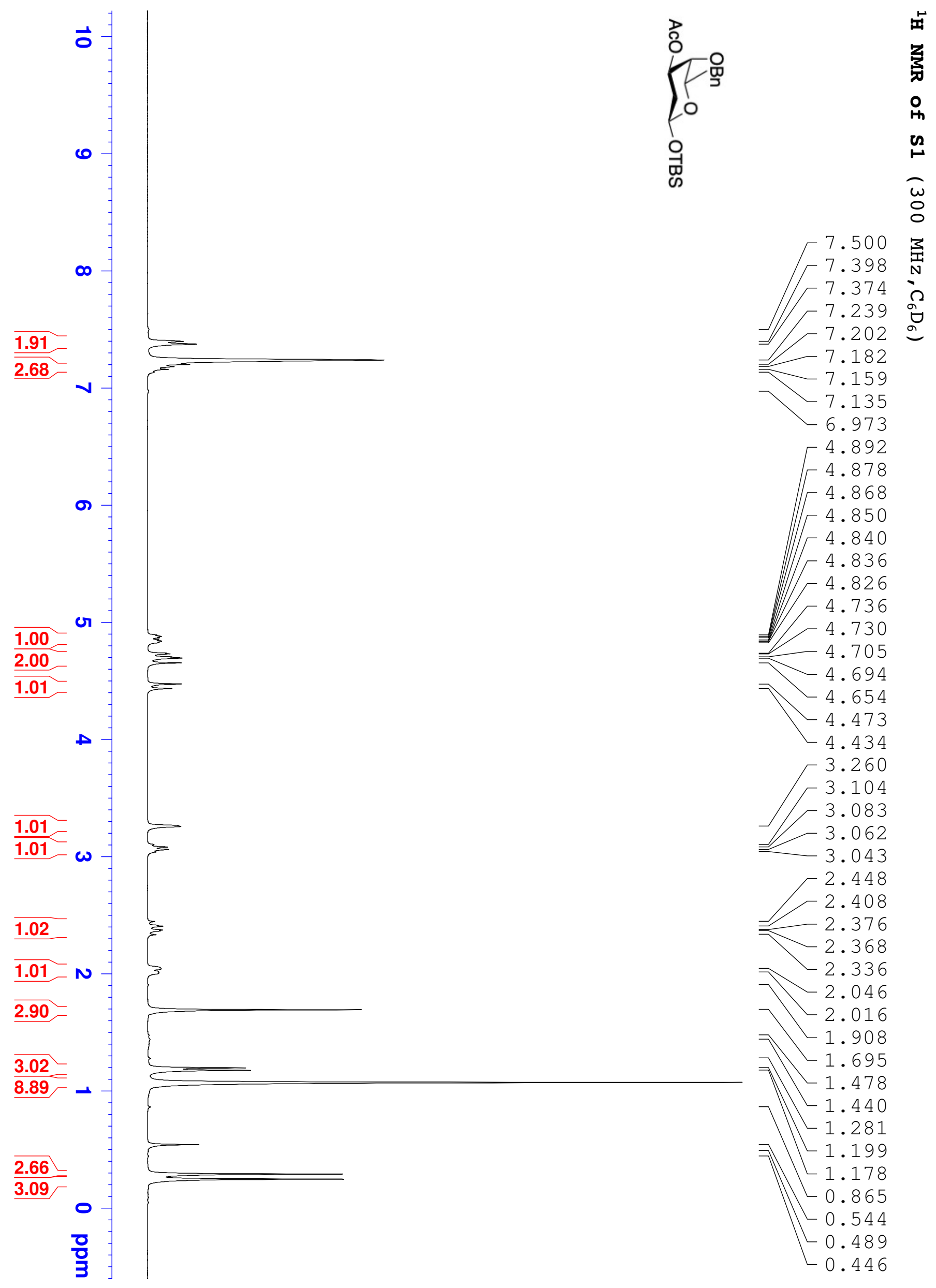


${ }^{13} \mathbf{C}$ NMR of $\mathbf{S 1}\left(125 \mathrm{MHz}, \mathrm{CDCl}_{3}\right)$

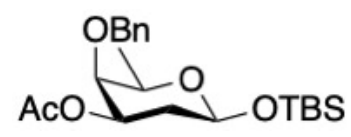

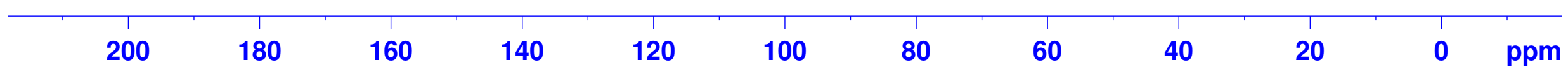


${ }^{1} \mathbf{H}-{ }^{1} \mathbf{H} \mathbf{~ G r} \cdot \mathbf{C O S Y}$ of $\mathbf{S 1}\left(500 \mathrm{MHZ}, \mathrm{CDCl}_{3}\right)$

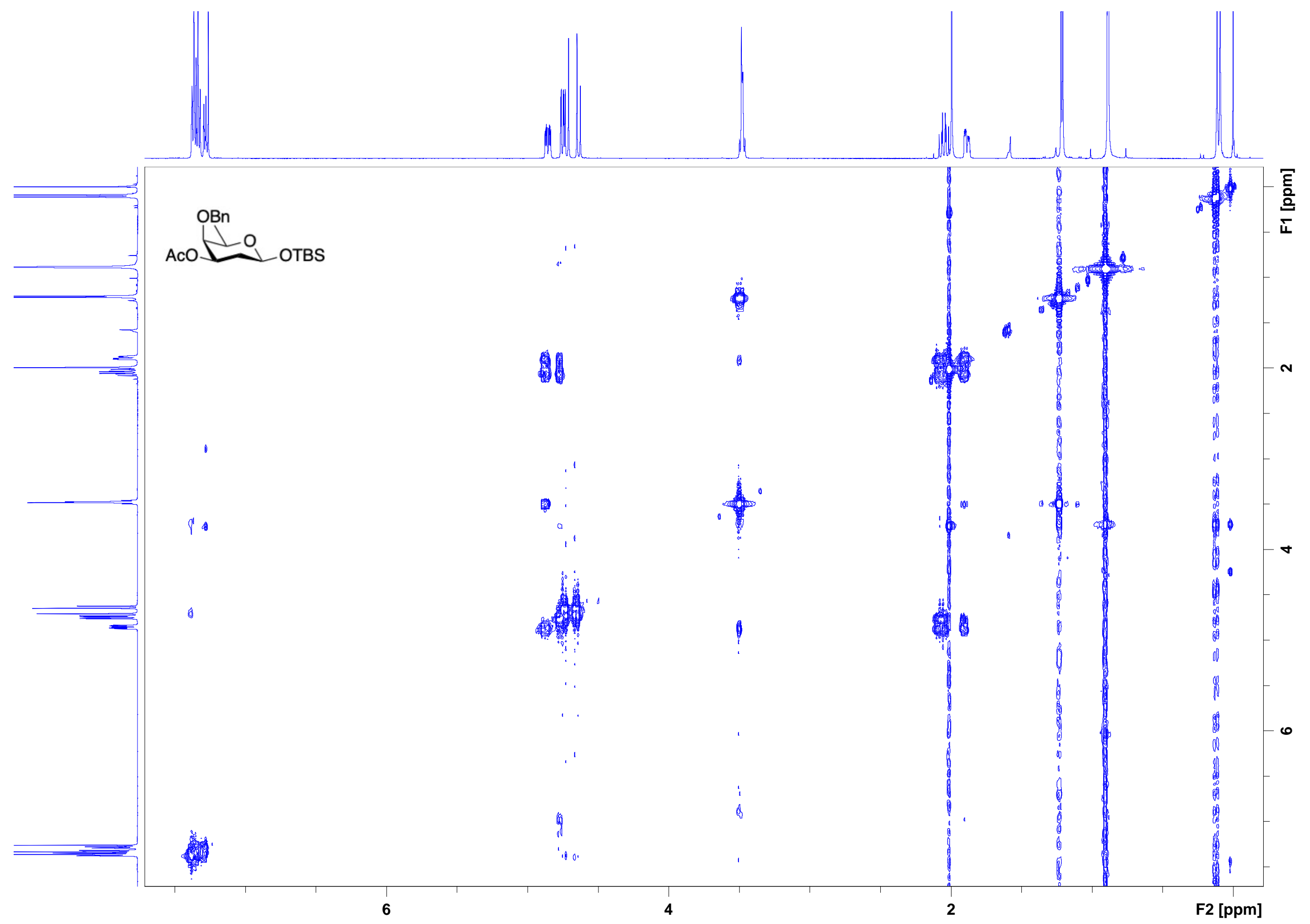




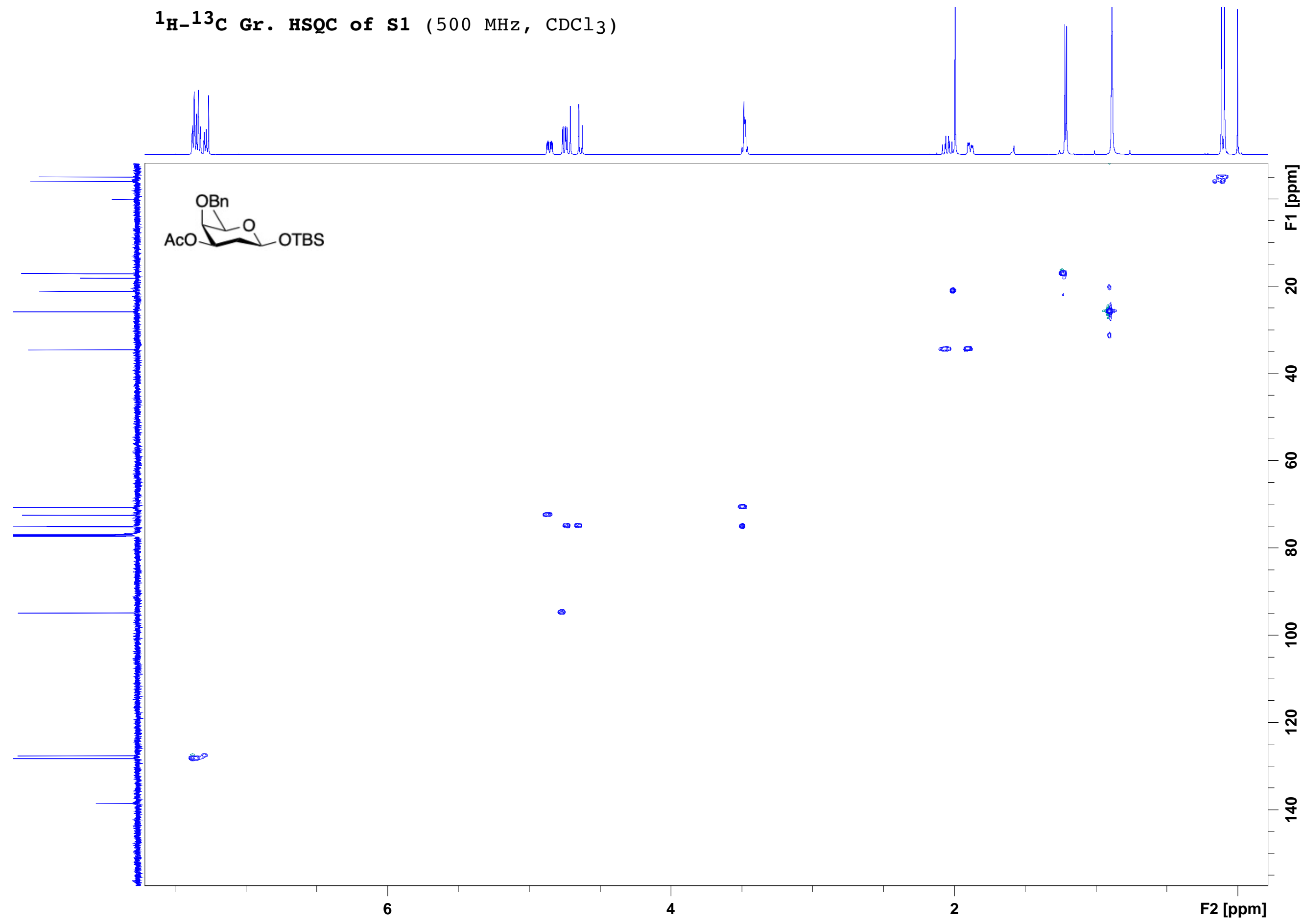


${ }^{1} \mathrm{H}$ NMR of (-)-28 (500 $\left.\mathrm{MHz}, \mathrm{CDCl}_{3}\right)$

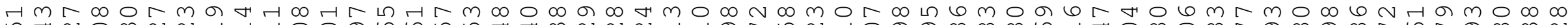

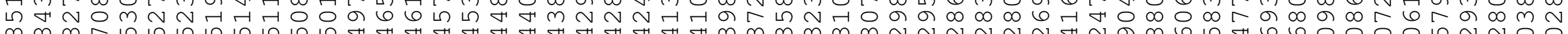

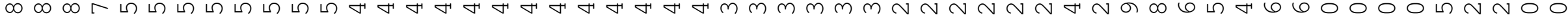

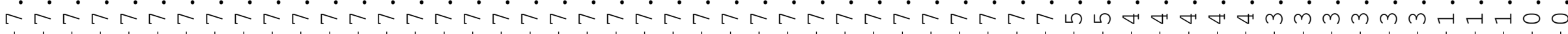
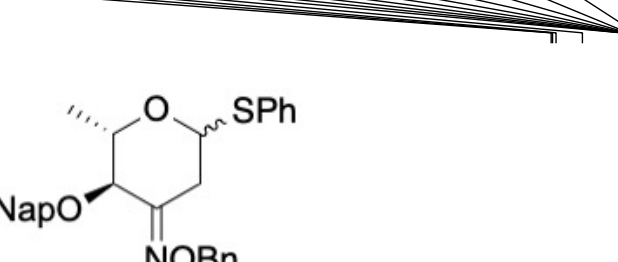
$\longdiv { \square }$

NOBn

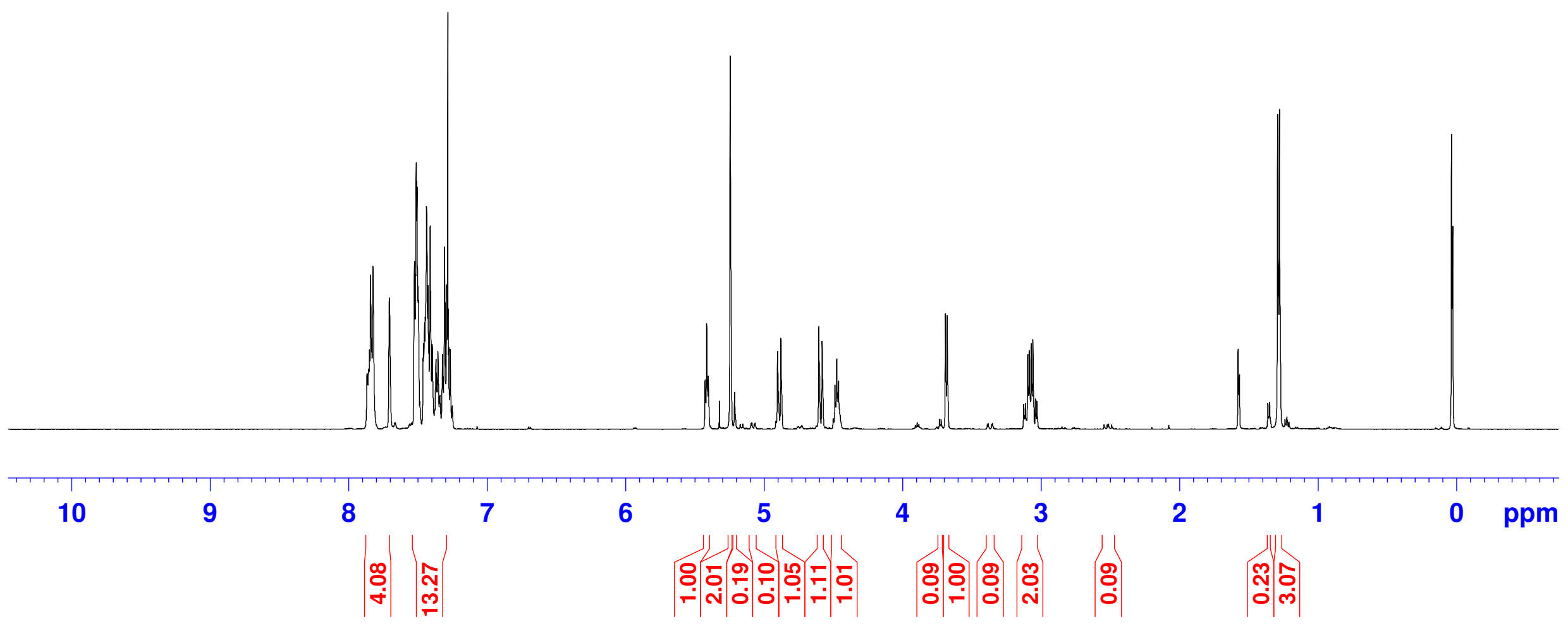


${ }^{13} \mathrm{C}$ NMR of (-)-28 (125 $\left.\mathrm{MHz}, \mathrm{CDCl}_{3}\right)$
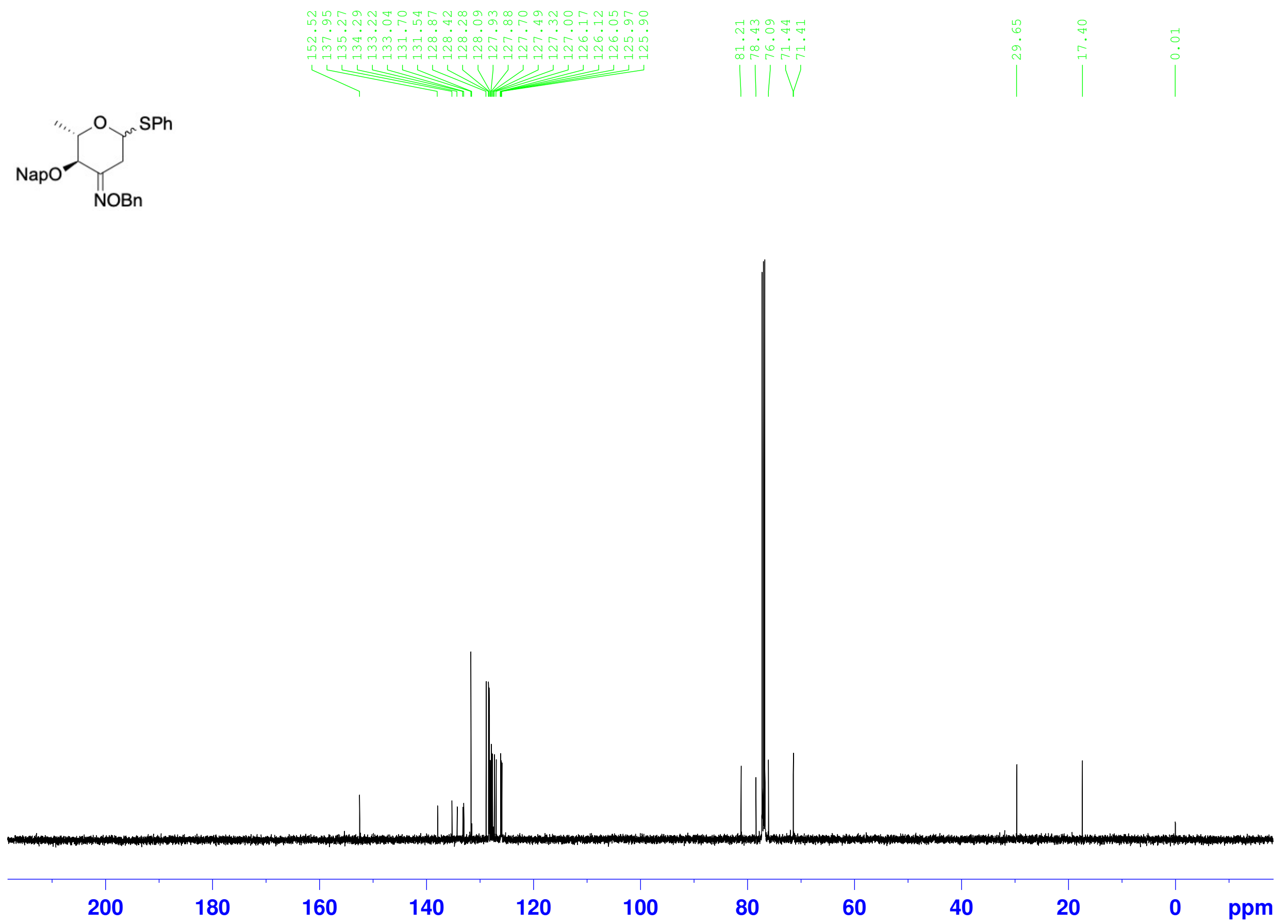
${ }^{1} \mathrm{H}$ NMR of (-)-11 (500 $\left.\mathrm{MHz}, \mathrm{CDCl}_{3}\right)$

ம

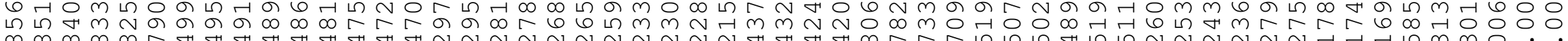

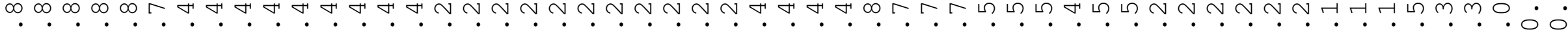

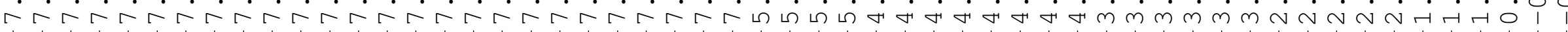

m $\mathrm{NapO} \mathrm{NHO}^{\mathrm{NH}_{2} \mathrm{SPh}}$

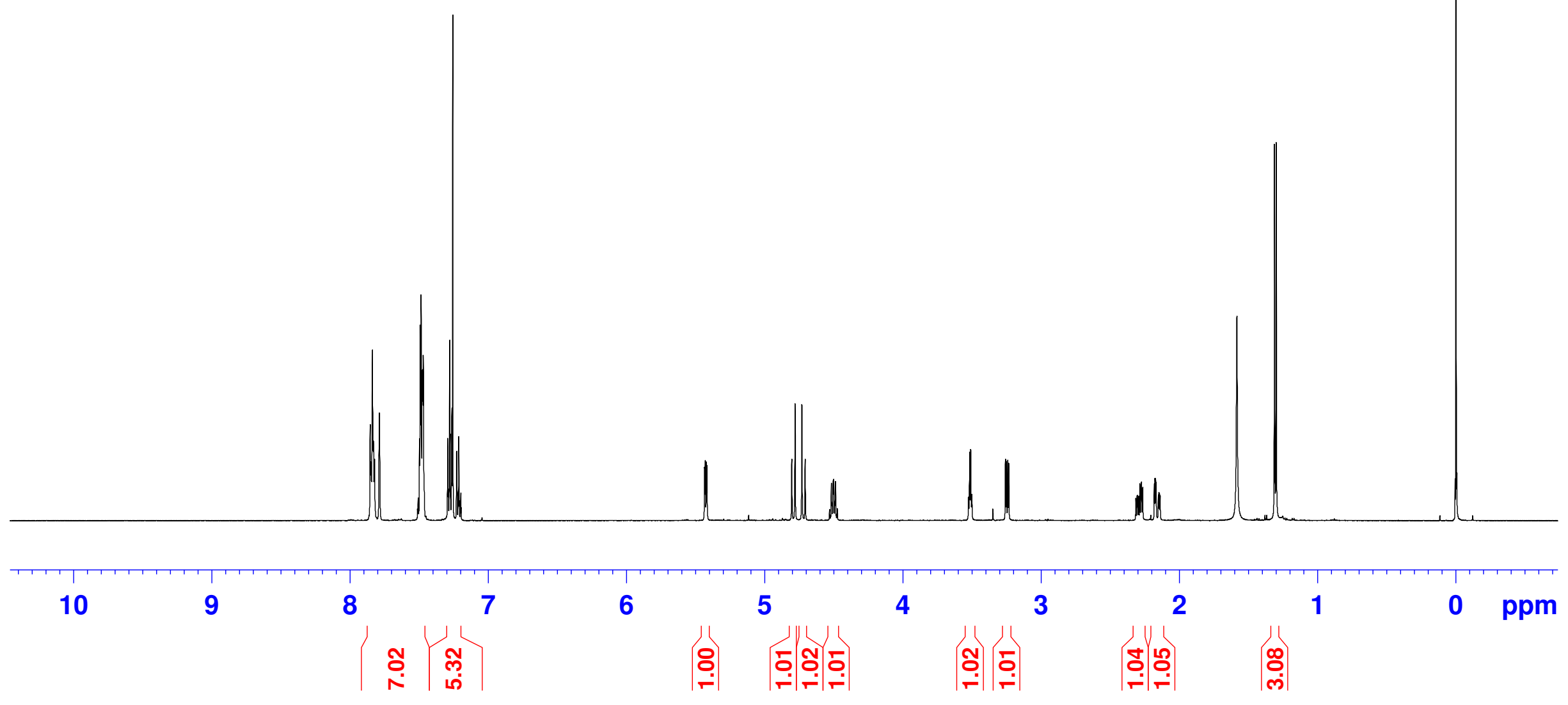


${ }^{13} \mathrm{C}$ NMR of $(-)-11\left(125 \mathrm{MHz}, \mathrm{CDCl}_{3}\right)$

$\mathrm{NapO} \mathrm{NH}^{\mathrm{NH}}$
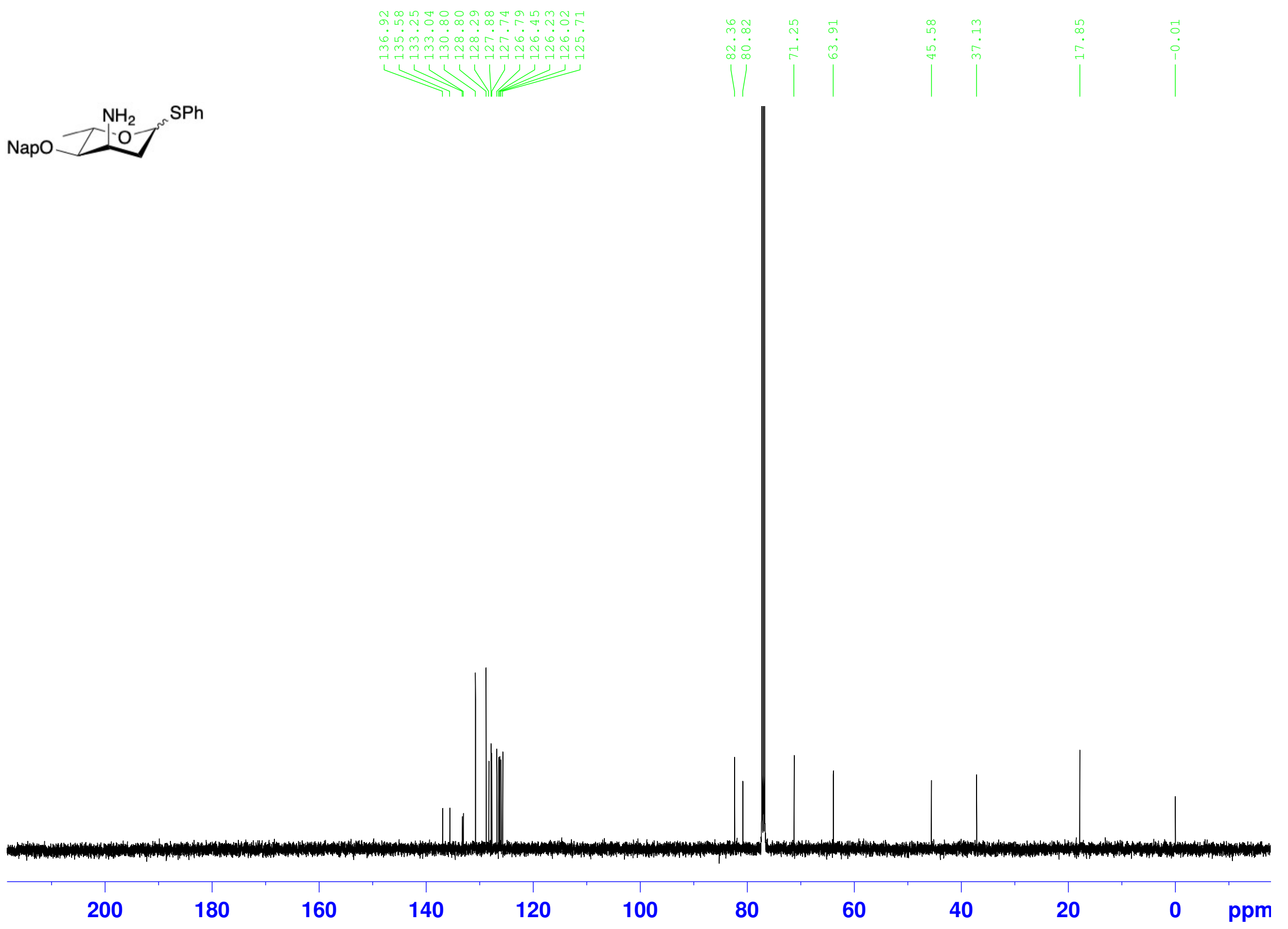


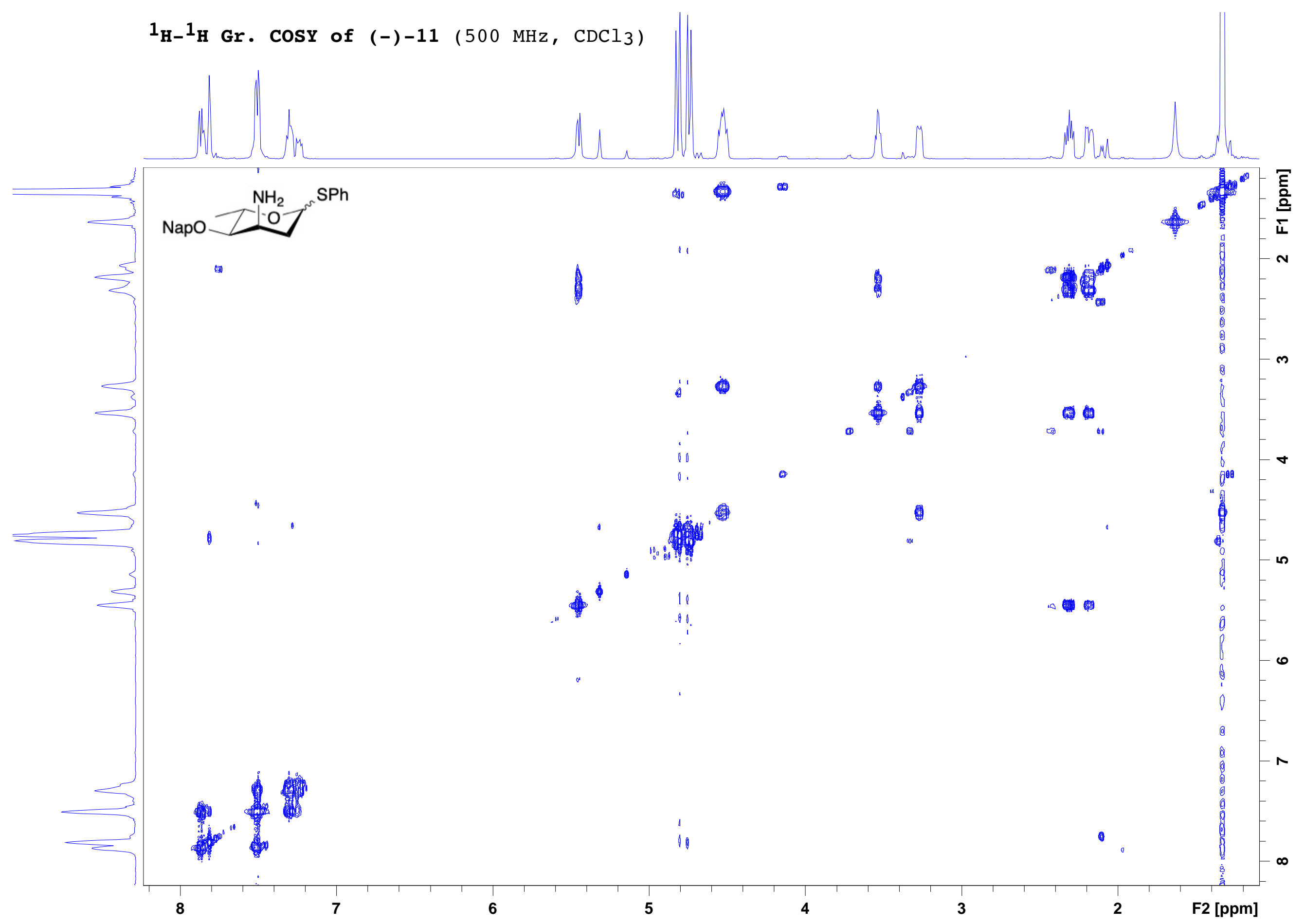


${ }^{1} \mathrm{H}-{ }^{13} \mathrm{C}$ Gr. HSQC of $(-)-11\left(500 \mathrm{MHz}, \mathrm{CDCl}_{3}\right)$

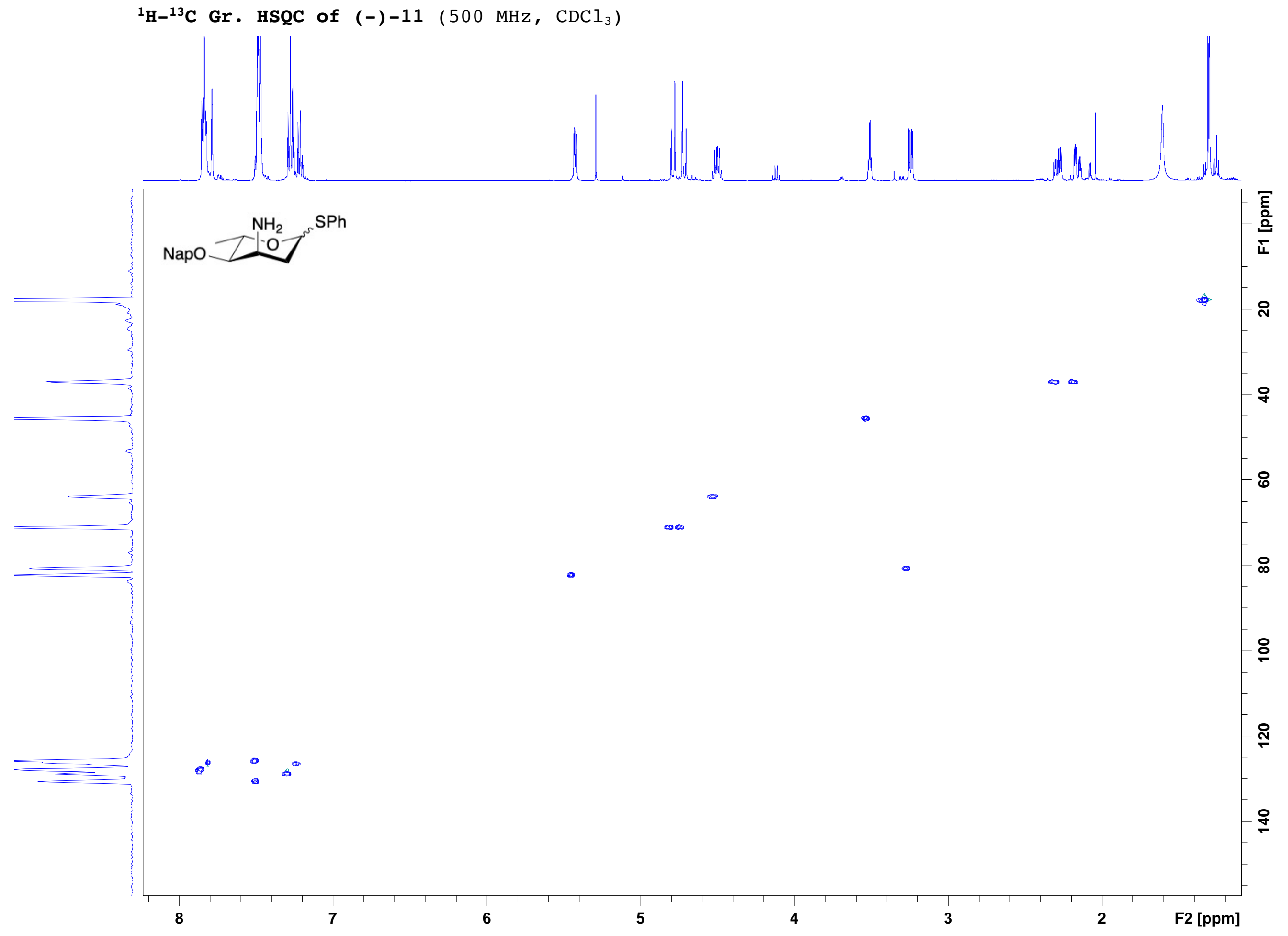


${ }^{1} \mathrm{H}$ NMR of (-) -29 (500 $\left.\mathrm{MHz}, \mathrm{CDCl}_{3}\right)$

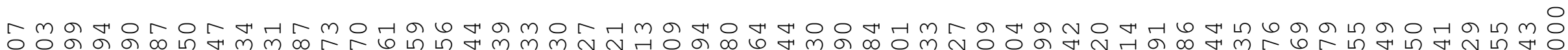
에

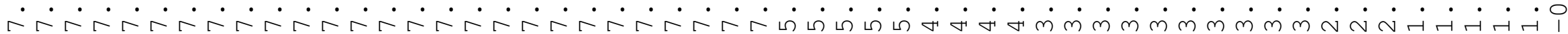

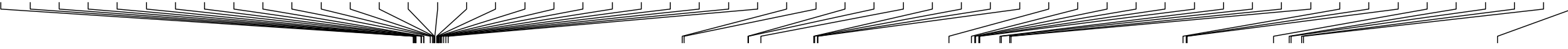
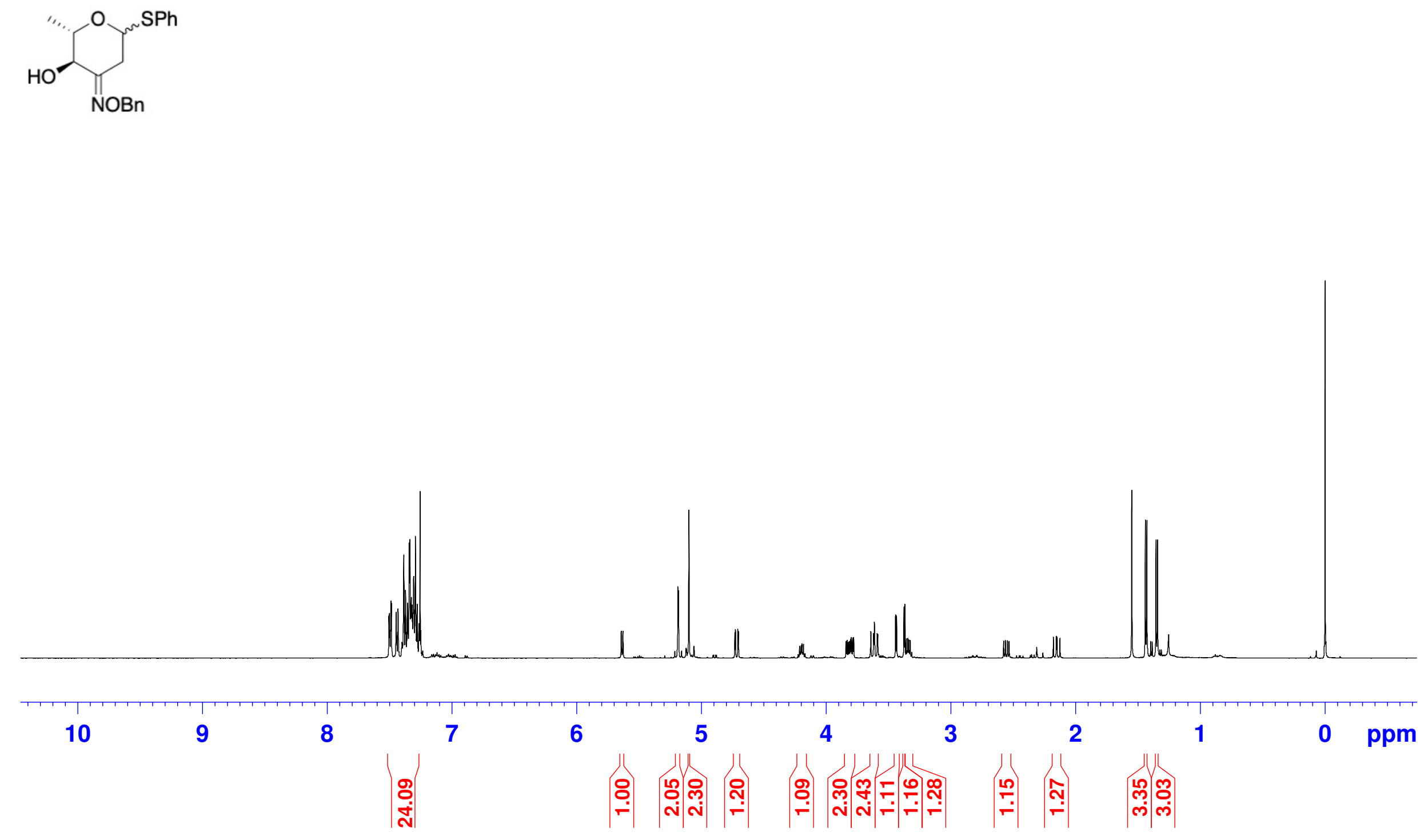
${ }^{13} \mathrm{C}$ NMR of (-)-29 (125 $\left.\mathrm{MHz}, \mathrm{CDCl}_{3}\right)$
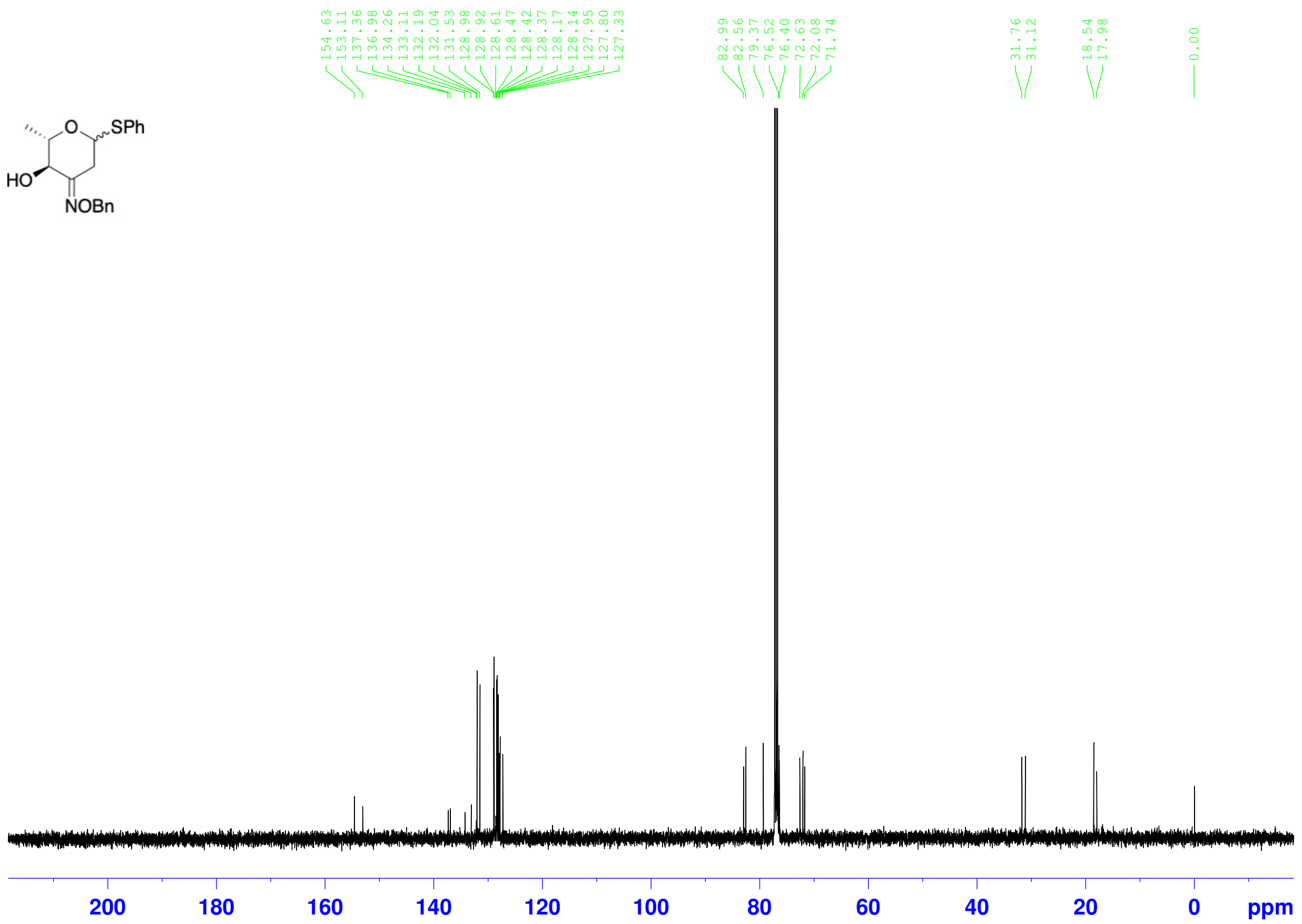


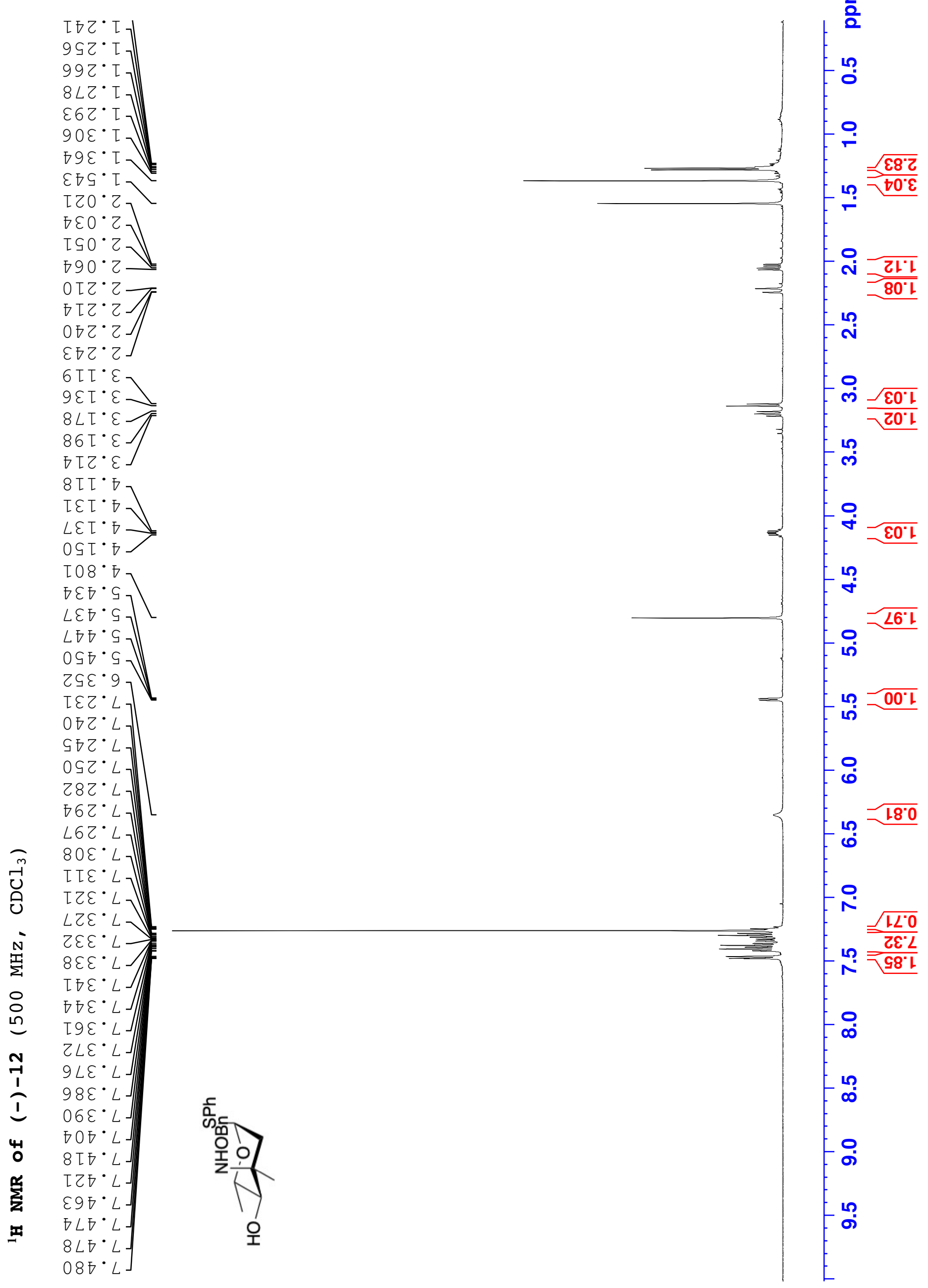




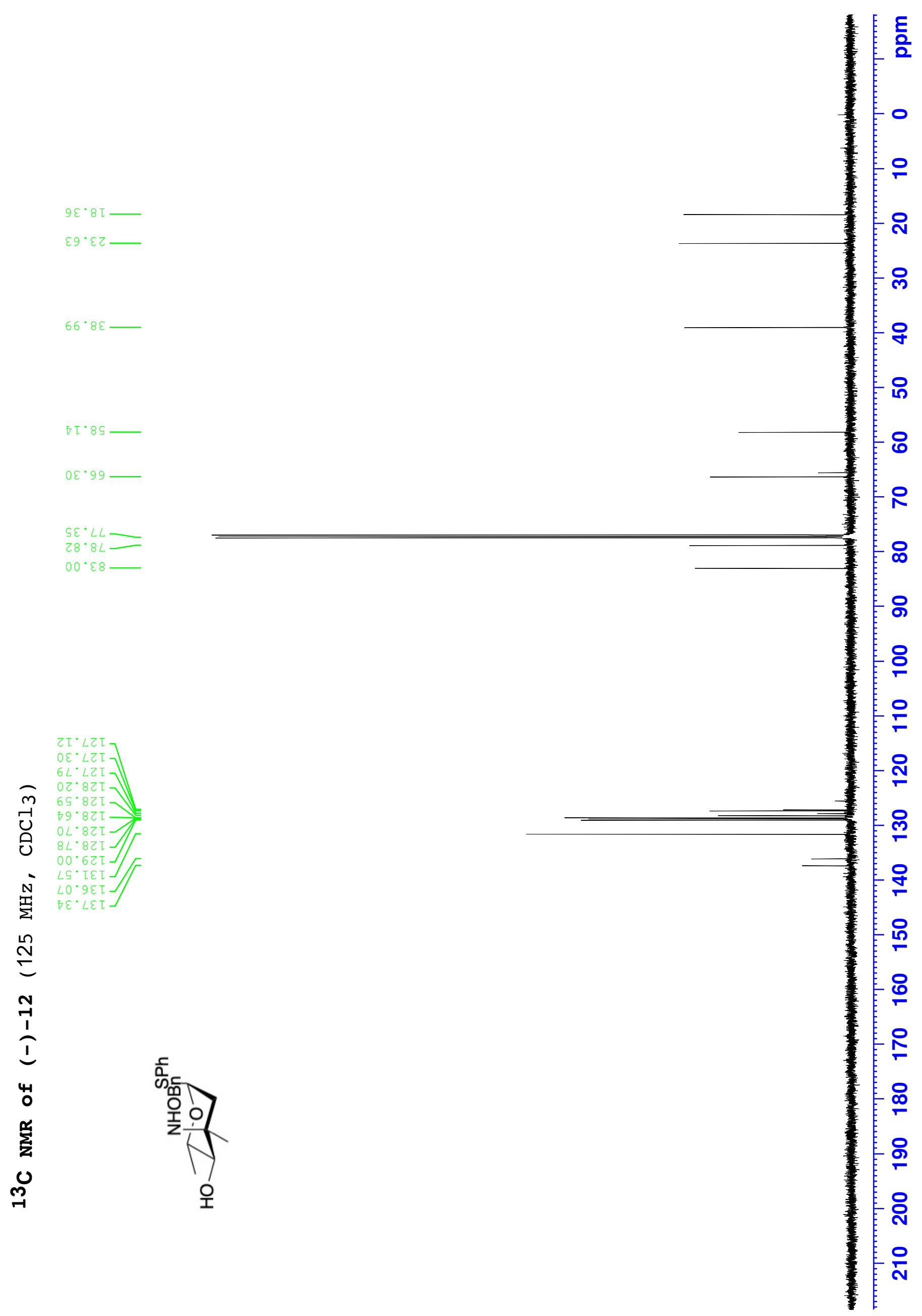




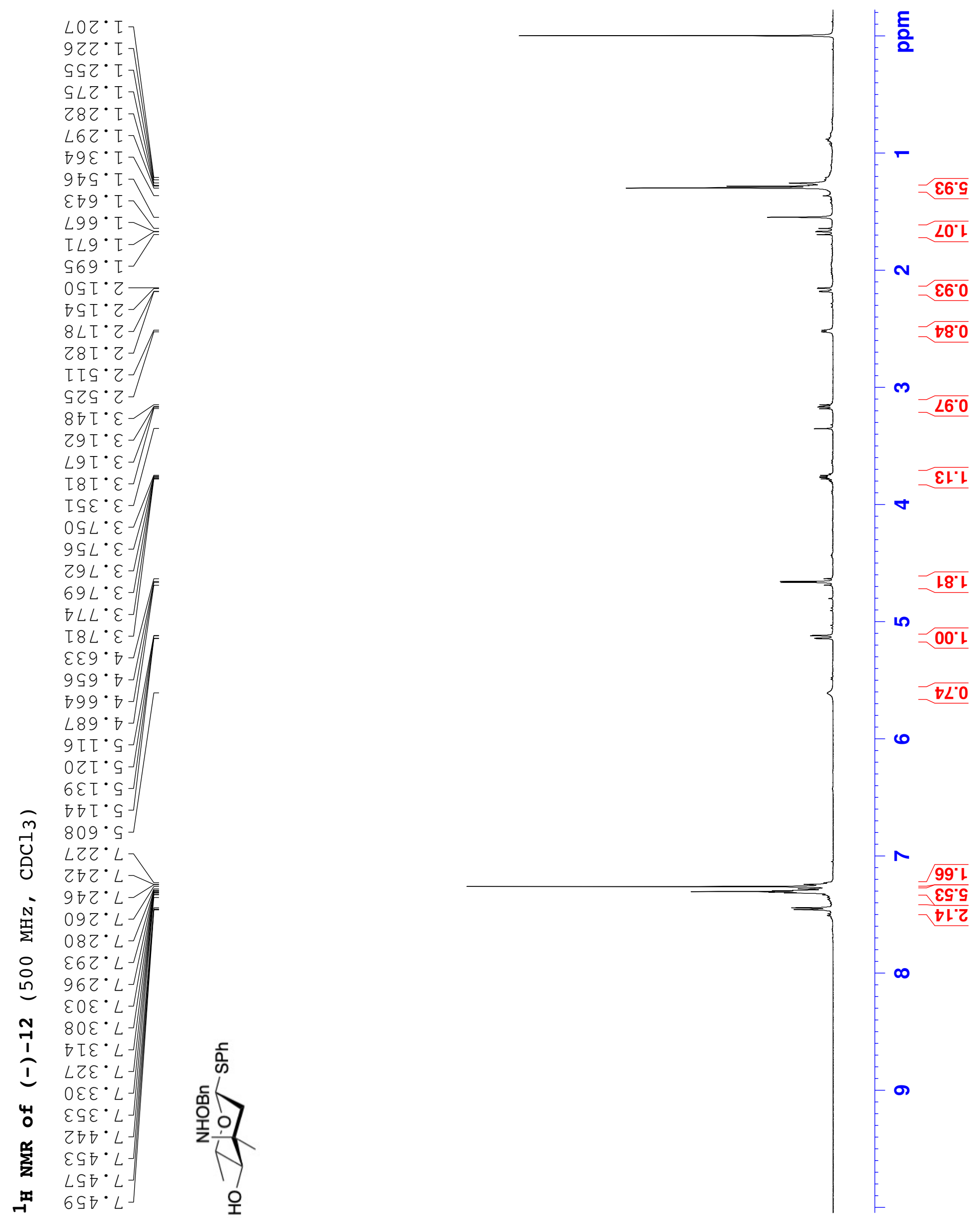


